UNIVERSIDADE DE SÃO PAULO

FACULDADE DE FILOSOFIA, CIÊNCIAS E LETRAS DE RIBEIRÃO PRETO PROGRAMA DE PÓS-GRADUAÇÃO EM PSICOLOGIA

\author{
ANDRÉ VILELA KOMATSU
}

\title{
O DESENVOLVIMENTO DO COMPORTAMENTO VIOLENTO NA ADOLESCÊNCIA
}

Tese apresentada à Faculdade de Filosofia, Ciências e Letras de Ribeirão Preto da Universidade de São Paulo, como parte das exigências para obtenção do título de Doutor em Ciências, obtido no Programa de Pós-Graduação em Psicologia.

Área de Concentração: Psicologia em Saúde e Desenvolvimento

Ribeirão Preto - SP 

UNIVERSIDADE DE SÃO PAULO

FACULDADE DE FILOSOFIA, CIÊNCIAS E LETRAS DE RIBEIRÃO PRETO PROGRAMA DE PÓS-GRADUAÇÃO EM PSICOLOGIA

\author{
ANDRÉ VILELA KOMATSU
}

\title{
O DESENVOLVIMENTO DO COMPORTAMENTO VIOLENTO NA ADOLESCÊNCIA
}

Tese apresentada à Faculdade de Filosofia, Ciências e Letras de Ribeirão Preto da Universidade de São Paulo, como parte das exigências para obtenção do título de Doutor em Ciências, obtido no Programa de PósGraduação em Psicologia.

Área de Concentração: Psicologia em Saúde e Desenvolvimento

Orientador: Prof ${ }^{\mathrm{a}}$ Dr $^{\mathrm{a}}$ Marina Rezende Bazon 
Autorizo a reprodução e divulgação total ou parcial deste trabalho, por qualquer meio convencional ou eletrônico, para fins de ensino, estudo e pesquisa, desde que citada a fonte.

FFCLRP - Departamento de Psicologia

Universidade de São Paulo

Komatsu, André Vilela.

O desenvolvimento do comportamento violento na adolescência./ André Vilela Komatsu - Ribeirão Preto, 2019.

219 p.: il. ; $30 \mathrm{~cm}$.

Tese de Doutorado apresentada à Faculdade de Filosofia, Ciências e Letras de Ribeirão Preto da USP. Área de Concentração: Psicologia em Saúde e Desenvolvimento.

Orientadora: Bazon, Marina Rezende.

1. Avaliação de risco de violência. 2. Comportamentos antissociais. 3. Criminologia Desenvolvimental. 4. Delinquência Juvenil. 5. Violência. 
Nome: Komatsu, André Vilela

Título: O desenvolvimento do comportamento violento na adolescência

Tese apresentada à Faculdade de Filosofia, Ciências e Letras de Ribeirão Preto da USP, como parte das exigências para obtenção do título de doutor em Ciências, Área: Psicologia em Saúde e Desenvolvimento.

Aprovado em: 26/04/2019

\section{Banca Examinadora}

Prof $^{\mathbf{a}}$. Dr ${ }^{\mathrm{a}}$. Marina Rezende Bazon

Instituição: Departamento de Psicologia, Faculdade de Filosofia, Ciências e Letras de Ribeirão Preto, Universidade de São Paulo (USP)

Assinatura:

Prof ${ }^{\text {a }}$ Dra . Carla Sofia Cardoso

Instituição: Escola de Criminologia, Faculdade de Direito, Universidade do Porto (UP) Assinatura:

Prof. Dr. Sergio Nojiri

Instituição: Faculdade de Direito de Ribeirão Preto, Universidade de São Paulo (USP) Assinatura:

Prof $^{\mathbf{a}}$. Dra. Adriane Xavier Arteche

Instituição: Escola de Ciências da Saúde, Pontifícia Universidade Católica do Rio Grande do Sul (PUC RS)

Assinatura:

Prof. Dr. Luis Flávio Sapori

Instituição: Departamento de Ciências Sociais, Pontifícia Universidade Católica de Minas Gerais (PUC MG)

Assinatura:

Prof. Dr. Jorge Luiz Bazan Gusman

Instituição: Instituto de Ciências Matemáticas e de Computação, Universidade de São Paulo (USP)

Assinatura: 



\section{DEDICATÓRIA}

Aos meus pais,

\section{Eliane Maria Vilela Komatsu e Takami Komatsu,}

minhas fontes de proteção,

que insistiram na minha educação mesmo quando as evidências apontavam um alto risco de fracasso;

que olharam para minha nota em Química no segundo bimestre e não enxergaram um mero três e meio, mas um rendimento $250 \%$ superior ao primeiro bimestre.

Sem vocês eu não teria chegado tão longe.

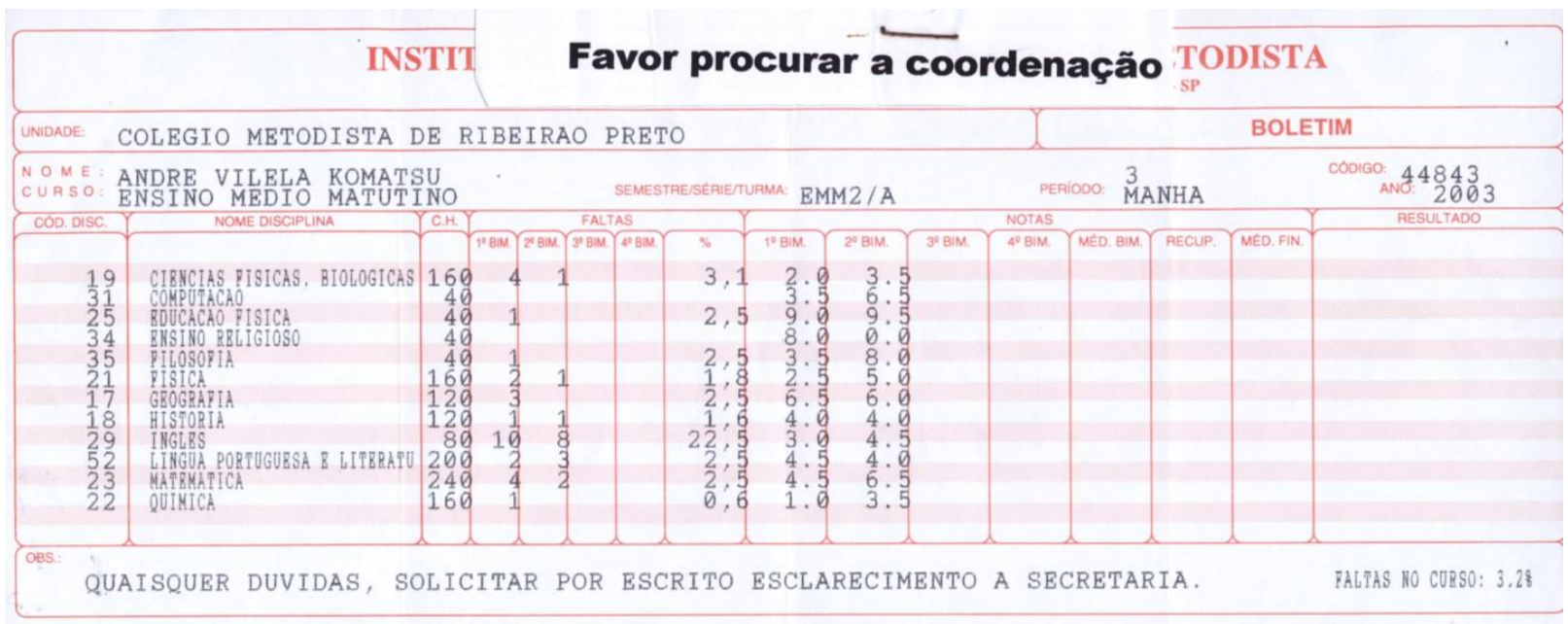

Figura I. Boletim escolar do autor no segundo ano do Ensino Médio 



\section{AGRADECIMENTOS}

À Coordenação de Aperfeiçoamento de Pessoal de Nível Superior (CAPES), pelo suporte financeiro durante minha trajetória no mestrado e no doutorado e durante meu estágio de doutorado-sanduíche em Barcelona. Sem esse financiamento, certamente eu não seria capaz de enveredar pela carreira acadêmica em Psicologia.

À Fundação CASA - Centro de Atendimento Socioeducativo ao Adolescente, por ter autorizado que parte dos dados utilizados nessa pesquisa fossem colhidos em suas dependências, demonstrando valorizar a ciência, apostando, assim, na melhoria das ações que devem ser levadas a cabo junto aos adolescentes em função dos quais existe.

À Prof ${ }^{a}$. Dr ${ }^{a}$. Marina Rezende Bazon, por sua notável contribuição para a minha formação científica e intelectual. Pela parceria que já dura 10 anos; e que seguirá progredindo. E por todo o tempo despendido com a revisão do conteúdo da tese.

Ao Prof. Dr. Antonio Andres Pueyo, por ter me recebido no Grupo de Estudios Avanzados en Violencia e proporcionado as melhores condições para que eu pudesse adquirir e desenvolver os conhecimentos apresentados no capítulo 3.

À Prof ${ }^{a}$. Dr ${ }^{a}$. Ruth Estevão, por todo apoio e incentivo fundamentais para a consecução das minhas pesquisas de mestrado e de doutorado. Pelas oportunidades de experiência e trabalhos desenvolvidos junto aos adolescentes em conflito com a lei. E, nesta tese, pela ajuda com as informações obtidas no fórum de Ribeirão Preto.

Aos Profs. Drs. Carla Cardoso e Sergio Nojiri, pelas contribuições na etapa de qualificação da tese.

À Ana Roberta Montanher, cujos esforços deram início ao presente estudo.

À Rafaelle C. S. Costa, por trocar os dias em que poderia aproveitar o sol de Barcelona para me ajudar, de forma imprescindível, na busca e na compilação dos dados da revisão apresentada no capítulo 2. 



\section{RESUMO}

Komatsu, A. V. (2019). O desenvolvimento do comportamento violento na adolescência. Tese de Doutorado, Departamento de Psicologia, Faculdade de Filosofia, Ciências e Letras de Ribeirão Preto, Universidade de São Paulo, Ribeirão Preto.

A presente tese buscou identificar os fatores proximais mais relevantes que afetam o desenvolvimento do comportamento violento na adolescência. Por meio de revisões sistemáticas e metanalíticas da literatura, o presente estudo identificou que os seguintes fatores de risco: exposição a eventos estressores, histórico de conduta violenta, fracasso em intervenções anteriores, baixo autocontrole, traços de psicopatia, emotividade negativa, transtornos de saúde mental específicos e de abuso de substâncias, pares infratores e envolvimento em gangues, isolamento social e inabilidade parental. Em relação aos fatores protetores, a revisão indicou que os fatores proximais mais relevantes consistem em: autocontrole, empatia, inteligência, atitudes positivas frente a figuras de autoridade e a intervenções, comprometimento com a escola ou ao trabalho, apoio social e vínculo com adultos pró-sociais. Na parte empírica dessa tese, objetivouse identificar os principais fatores associados à conduta violenta em adolescentes em conflito com a lei brasileira e testar a capacidade preditiva desses fatores. Participaram 118 adolescentes do sexo masculino entre 15 e 19 anos que cumpriam medida socioeducativa no município de Ribeirão Preto - SP, dos quais 78 foram entrevistados em um segundo momento (T2), 18 meses após a primeira entrevista (T1). Os adolescentes completaram o Questionário sobre Comportamentos Juvenis (QCJ) e o Inventário de Jesness - Revisado Brasileiro (IJ-R-Br) no T1 e no T2, e foram testados nos testes de Stroop - Victoria (TS-V) e das Torres de Londres (TOL) somente no T2. Adicionalmente, foram levantados os históricos de boletins de ocorrência dos adolescentes junto ao fórum da cidade. Os adolescentes foram divididos em grupos Violento (GV) e não violento (GNV) e comparados nas escalas psicossociais do QCJ, nas escalas de personalidade do IJ-R-Br e nos testes TS-V e TOL. Posteriormente, 70\% da amostra foi utilizada para a construção de dois modelos para testar o poder preditivo para o envolvimento em condutas violentas de forma retrospectiva nos $30 \%$ dos adolescentes que não participaram da construção dos modelos. Adolescentes infratores com trajetória de conduta violenta apresentaram pior desempenho que adolescentes infratores sem trajetória de conduta violenta em variáveis dos domínios Pessoal (capacidade cognitiva, crenças, valores e aspectos de personalidade), Familiar (apego e supervisão parental), Escolar (desempenho acadêmico), Pares Infratores e Comunitário (percepção de violência). No T2, algumas dessas variáveis deixaram de produzir efeito. Em termos preditivos, o modelo 1 apresentou acurácia de $74 \%$ e o modelo 2 de $83 \%$, destacando-se o poder preditivo das escalas do IJ-R-Br (Desadaptação Social e Transtorno de Conduta), do QCJ (Pares Infratores e Atraso Escolar) e especialmente do histórico de conduta violenta. Destaca-se que algumas variáveis impactam no desenvolvimento da conduta violenta especificamente na adolescência, reduzindo seu efeito no início da vida adulta, enquanto outras mantém seu efeito ao longo do tempo. E o fato de existirem indicadores que podem predizer o envolvimento em comportamentos violentos com boa acurácia traz contribuições para o conhecimento da realidade brasileira e também implicações para as políticas públicas e pesquisas futuras.

Palavras-chave: Avaliação de risco de violência. Comportamentos antissociais. Criminologia Desenvolvimental. Delinquência Juvenil. Violência. 



\begin{abstract}
Komatsu, A. V. (2019). The development of violent behavior during adolescence. Tese de Doutorado, Departamento de Psicologia, Faculdade de Filosofia, Ciências e Letras de Ribeirão Preto, Universidade de São Paulo, Ribeirão Preto.

The present thesis sought to identify the most relevant proximal factors that affect the development of violent behavior during adolescence. Through the systematic and metaanalytic reviews of the literature, the present study identified the following risk factors: exposure to stressful events, history of violent behavior, failure in previous interventions, low self-control, traits of psychopathy, negative emotionality, mental health disorders and substance abuse, peer offenders and gang involvement, social isolation and parental inability. Regarding the protective factors, the review indicated that the most relevant proximal factors consist in: self-control, empathy, intelligence, positive attitudes toward authority figures and interventions, commitment to school or work, social support and attachment to prosocial adults. In the empirical part of this thesis, the objective was to identify the main factors associated with violent behavior in adolescents in conflict with Brazilian law and to test the predictive validity of these factors. A total of 118 male adolescents between 15 and 19 years old in conflict with the lay in the city of Ribeirão Preto - SP, of which 78 were interviewed in a second wave (T2), 18 months after the first interview (T1). The adolescents completed the Questionnaire about Youth Behavior (QCJ) and the Jesness Inventory - Revised Brazilian Version (IJ-R-Br) on T1 and T2, and were tested in Stroop Test - Victoria (TS-V) and Tower of London (TOL) on T2 only. Additionally, the historical records of teenagers' official offenses were collected at the city forum. Adolescents were divided into Violent $(\mathrm{GV})$ and non-violent $(\mathrm{NGV})$ groups and compared on the QCJ psychosocial scales, IJ-R-Br personality scales and TS-V and TOL tests. Subsequently, $70 \%$ of the sample was used to construct two models to test the predictive power to engage in violent behavior retrospectively in $30 \%$ of adolescents who did not participate in the construction of the models. Adolescents with violent behavior trajectories presented worse performance than adolescents with no trajectory of violent behavior in variables of the domains Personal (cognitive capacity, beliefs, values and personality aspects), Family (attachment and parental supervision), School (academic performance), Peers (offenders) and Community (perception of violence). On T2, some of these variables no longer have an effect. In predictive terms, model 1 presented an accuracy of $74 \%$ and model 2 of $83 \%$, highlighting the predictive power of the IJ-R-Br scales (Social Disorder and Conduct Disorder), QCJ scales (Peer Offenders and School failure) and especially the history of violent conduct. It is noteworthy that some variables impact on the development of violent behavior specifically during adolescence, reducing its effect in early adult life, while others maintain their effect over time. And the fact that there are indicators that can predict the involvement in violent behaviors with good accuracy brings contributions to the knowledge of the Brazilian context and also has important implications for public policies and future research.
\end{abstract}

Keywords: Violence Risk Assessment. Antisocial behavior. Developmental Criminology. Juvenile Delinquency. Violence. 



\section{LISTA DE FIGURAS}

Figura 1.1. Série temporal do número e taxa de homicídios por 100 mil habitantes PÁG. 28 no Brasil (2006-2016)

Figura 2.1. Forest plot da razão de chances de se envolver em comportamento PÁG. 51 violento dado à exposição à violência

Figura 2.2. Forest plot da razão de chances de se envolver em comportamento PÁG. 52 violento dado à exposição cumulativa à violência

Figura 2.3. Forest plot da razão de chances de se envolver em comportamento PÁG. 54 violento dado o histórico de problemas de comportamentos

Figura 2.4. Forest plot da razão de chances de se envolver em comportamento PÁG. 57 violento dado o baixo autocontrole

Figura 2.5. Forest plot da razão de chances de se envolver em comportamento PÁG. 58 violento dada a emotividade negativa

Figura 2.6. Forest plot da razão de chances de se envolver em comportamento PÁG. 60 violento dado os traços de psicopatia

Figura 2.7. Forest plot da razão de chances de se envolver em comportamento PÁG. 62 violento dado os transtornos mentais

Figura 2.8. Forest plot da razão de chances de se envolver em comportamento PÁG. 65 violento dada a associação a pares infratores

Figura 2.9. Forest plot da razão de chances de se envolver em comportamento PÁG. 66 violento dado o isolamento social

Figura 2.10. Forest plot da razão de chances de se envolver em comportamento 
Figura 4.3. Adolescentes que participaram em cada etapa da pesquisa e PÁG. 121 instrumentos empregados na coleta de dados em cada etapa

Figura 4.4. Escores normatizados dos adolescentes no T1, do GNV no T2 e do PÁG. 150 GV no T2 em relação às escalas do QCJ 


\section{LISTA DE TABELAS}

Tabela 1.1 - Número de adolescentes por natureza de medida socioeducativa (2014-2018)

PÁG. 31

Tabela 2.1 - Características dos estudos sobre exposição à violência

PÁG. 50

Tabela 2.2 - Características dos estudos sobre o efeito cumulativo de experiências adversas

PÁG. 52

Tabela 2.3 - Características dos estudos sobre histórico de problemas de comportamento

PÁG. 53

Tabela 2.4 - Características dos estudos sobre autocontrole

PÁG. 56

Tabela 2.5 - Características dos estudos sobre emotividade negativa

PÁG. 58

Tabela 2.6 - Características dos estudos sobre os traços de psicopatia

PÁG. 59

Tabela 2.7 - Características dos estudos sobre condições de saúde mental

PÁG. 61

Tabela 2.8 - Características dos estudos sobre pares infratores

PÁG. 64

Tabela 2.9 - Características dos estudos sobre isolamento social

PÁG. 66

Tabela 2.10 - Características dos estudos sobre inabilidade parental

PÁG. 67

Tabela 2.11 - Síntese dos fatores de risco mais relevantes para a conduta violenta

PÁG. 69

Tabela 2.12 - Síntese dos fatores de proteção mais relevantes para a conduta violenta

PÁG. 70

Tabela 3.1 - Síntese dos principais instrumentos de avaliação de risco

PÁG. 89 
Tabela 4.1 - Fatores de risco associados à delinquência e instrumentos utilizados para mensurá-los

PÁG. 97

Tabela 4.2 - Fatores de risco associados à delinquência e instrumentos utilizados para mensurá-los

PÁG. 98

Tabela 4.3 - Condutas antissociais avaliadas pelo Questionário sobre PÁG. 109 Comportamentos Juvenis (QCJ)

Tabela 4.4 - Síntese das escalas do Inventário de Jesness

PÁG. 111

Tabela 4.5 - Frequência de delitos oficiais atribuídos aos adolescentes investigados $(\mathrm{n}=118)$

PÁG. 124

Tabela 4.6 - Quantidade de adolescentes que revelaram cada comportamento delituoso investigado pelo QCJ (Autorrevelados)

PÁG. 125

Tabela 4.7 - Quantidade de adolescentes e frequência de comportamentos delituosos investigados pelo QCJ no último ano (Autorrevelados)

PÁG. 126

Tabela 4.8 - Medidas de tendência central dos comportamentos delituosos autorrevelados

PÁG. 127

Tabela 4.9 - Quantidade de adolescentes por categoria de uso de substâncias e relacionamento com os pais

PÁG. 127

Tabela 4.10 - Médias, desvios-padrão, medianas, mínimos e máximos dos adolescentes na pontuação das escalas do QCJ no T1 e no T2

PÁG. 128

Tabela 4.11 - Escores normatizados nas escalas do IJ-R-Br

PÁG. 130 
Tabela 4.12 - Comparação das médias de idade do primeiro delito, diversidade e frequência anual de delitos entre os grupos GNV e GV (Autorrelato - T1)

PÁG. 132

Tabela 4.13 - Comparação das médias das escalas do QCJ entre os grupos GNV e GV (Autorrelato - T1)

PÁG. 133

Tabela 4.14 - Comparação das médias do escore normatizado do IJ-R-Br entre os grupos GNV e GV (Autorrelato - T1)

PÁG. 134

Tabela 4.15 - Comparação das médias de idade do primeiro delito, diversidade e frequência anual de delitos entre os grupos GNV e GV (Informação Oficial - T1) PÁG. 136

Tabela 4.16 - Comparação das médias nos escores das escalas do QCJ entre os grupos NV e V (Informação oficial - T1)

PÁG. 137

Tabela 4.17 - Comparação das médias nos escores normatizados das escalas do IJ-R-Br entre os grupos NV e V (Informação oficial - T1)

PÁG. 138

Tabela 4.18 - Comparação das médias de idade do primeiro delito, diversidade e frequência anual de delitos entre os grupos GNV e GV (Autorrelato - T2)

PÁG. 140

Tabela 4.19 - Comparação das médias nas escalas do QCJ entre os grupos GNV e GV (Autorrelato - T2)

PÁG. 141

Tabela 4.20 - Comparação das médias de idade do primeiro delito, diversidade e frequência anual de delitos entre os grupos GNV e GV (Autorrelato - T2)

PÁG. 142

Tabela 4.21 - Comparação das médias nos escores dos testes Stroop e TOL entre os grupos NV e V (Autorrelato - T2)

PÁG. 144

Tabela 4.22 - Comparação das médias de idade do primeiro delito, diversidade e frequência anual de delitos entre os grupos GNV e GV (Informação oficial - T2) 
Tabela 4.23 - Comparação das médias nos escores das escalas do QCJ entre os grupos NV e V (Informação oficial - T2)

PÁG. 147

Tabela 4.24 - Comparação das médias nos escores normatizados das escalas do IJ-R-Br entre os grupos NV e V (Informação oficial - T2)

PÁG. 148

Tabela 4.25 - Comparação das médias nos escores dos testes Stroop e TOL entre os grupos NV e V (Informação oficial - T2)

PÁG. 149

Tabela 4.26 - Comparação dos escores do grupo V-NV $(n=15)$ com ele mesmo em relação à diversidade de atos divergentes e diversidade e frequência anual de delitos - teste de Wilcoxon

PÁG. 151

Tabela 4.27 - Comparação dos escores do grupo V-NV $(n=15)$ com ele mesmo nas escalas do QCJ - teste de Wilcoxon

PÁG. 152

Tabela 4.28 - Comparação dos escores do grupo V-NV $(n=15)$ com ele mesmo nas escalas do IJ-R-Br - teste de Wilcoxon

PÁG. 153

Tabela 4.29 - Comparação dos escores do grupo NV-V $(n=7)$ com ele mesmo em relação à diversidade de atos divergentes e diversidade e frequência anual de delitos - teste de Wilcoxon

PÁG. 153

Tabela 4.30 - Comparação dos escores do grupo NV-V $(n=7)$ com ele mesmo PÁG. 154 nas escalas do IJ-R-Br - teste de Wilcoxon

Tabela 4.31 - Comparação dos escores do grupo NV-V $(n=7)$ com ele mesmo PÁG. 155 nas escalas do QCJ - teste de Wilcoxon

Tabela 4.32 - Modelo de Regressão Logística para a emissão de delito violento PÁG. 155

Tabela 4.33 - Acurácia dos modelos 1 e 2 para predizer a prática de delito 
Tabela 5.1 - Programas que se mostraram efetivos para reduzir o comportamento violento

PÁG. 183 

LISTA DE ABREVIATURAS E SIGLAS

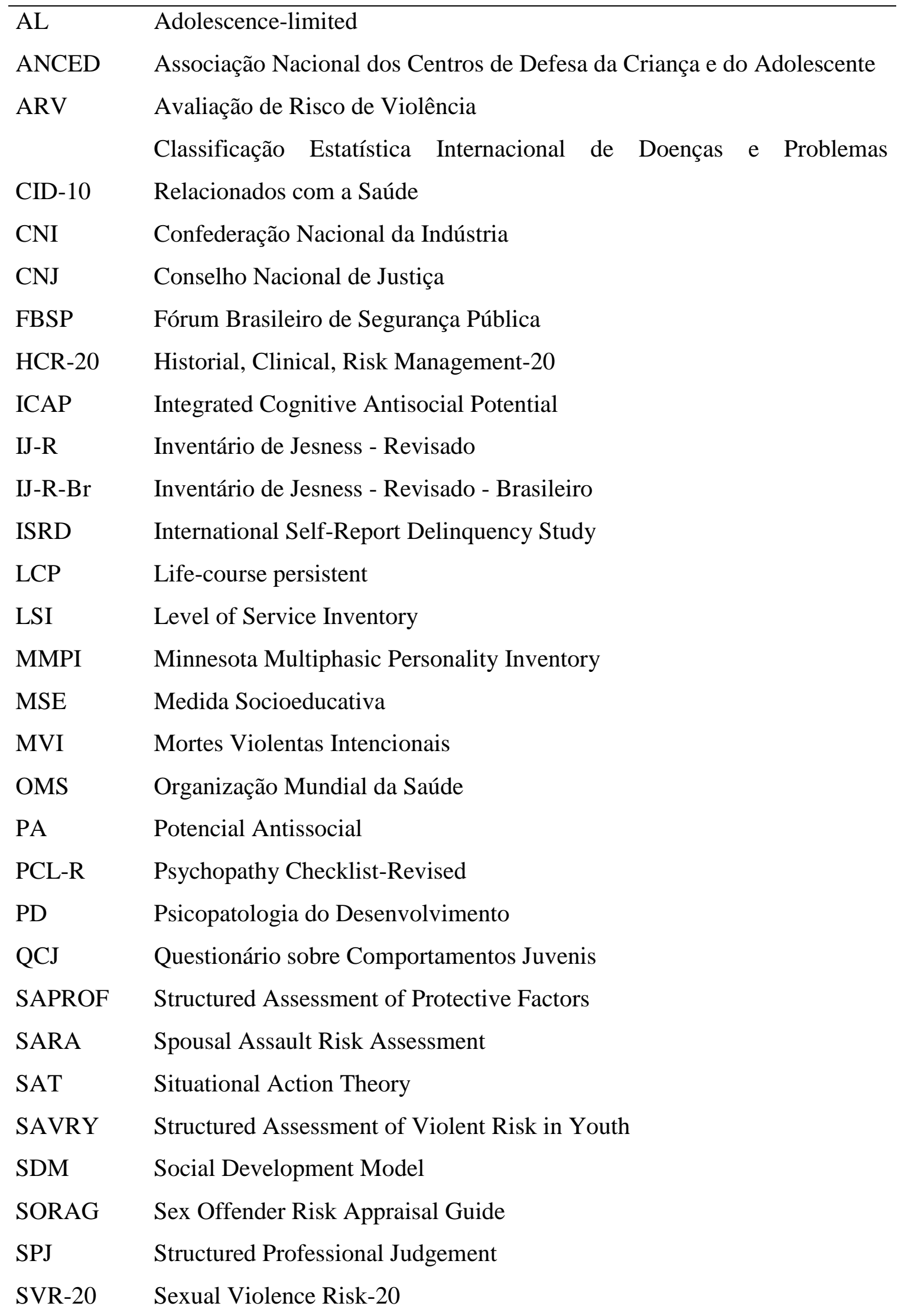


UPJ Unstructured Professional Judgement

VRAG Violence Risk Appraisal Guide 


\section{SUMÁRIO}

CAPÍtULO 1

A VIOLÊNCIA CRIMINAL NO BRASIL E OS DESAFIOS IMPOSTOS AO SISTEMA DE JUSTIÇA

1.1. A violência criminal no Brasil e o papel dos adolescentes na criminalidade .. 27

1.2. Desafios da justiça juvenil e a contribuição da presente tese 32

\section{CAPÍTULO 2}

MARCO TEÓRICO: A PSICOPATOLOGIA DO DESENVOLVIMENTO ........ 37

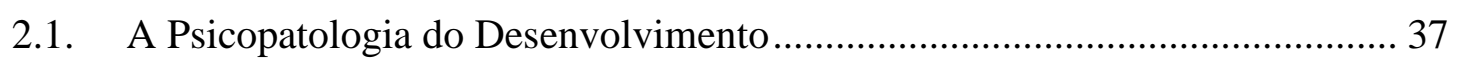

2.2. Fator de risco, fator de promoção, fator de proteção e resiliência: definições 42

2.3. Fatores de risco e de proteção relacionados ao engajamento infracional envolvendo condutas delituosas violentas: revisão sistemática da literatura ............. 47

2.3.1. Os fatores de risco para a conduta violenta .......................................... 49

2.3.2. Os fatores de proteção para a conduta violenta ....................................... 69

2.4. Teorias relativas à delinquência juvenil na perspectiva da Criminologia Desenvolvimental

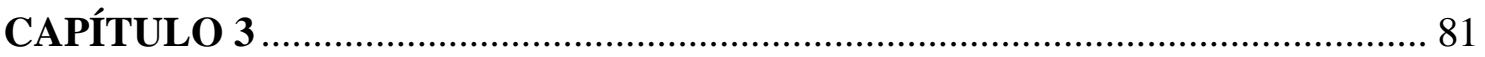

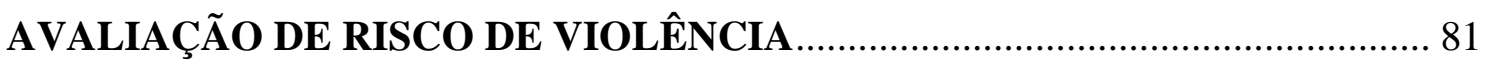

3.1. Razões para o uso da Avaliação de Risco de Violência ................................... 81

3.2. A evolução dos procedimentos de avaliação de risco de violência .................. 85

3.3. Instrumentos de avaliação de risco de violência............................................... 86

CAPÍtULO 4 95

ESTUDO EMPÍRICO: O DESENVOLVIMENTO DO COMPORTAMENTO VIOLENTO EM UMA AMOSTRA DE ADOLESCENTES EM CONFLITO COM A LEI 95

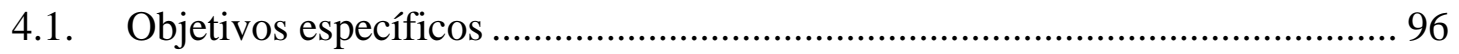

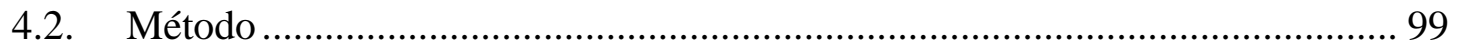

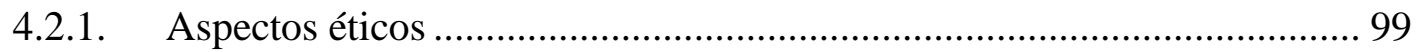

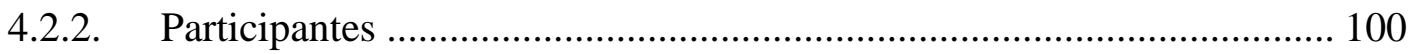

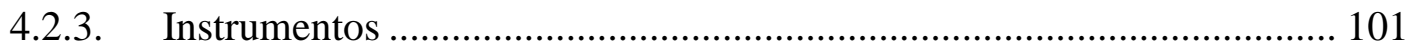

4.2.3.1. Questionário Sobre Comportamentos Juvenis (QCJ) ......................... 101

4.2.3.2. Inventário de Jesness - Revisado Brasileiro (IJ-R-Br) ...................... 110 
4.2.3.3. Teste de Stroop - Versão Victoria ..................................................... 116

4.2.3.4. Torres de Londres (TOL) ............................................................... 118

4.2.4. Procedimento de coleta de dados ..................................................... 120

4.2.5. Procedimento de análise de dados ....................................................... 122

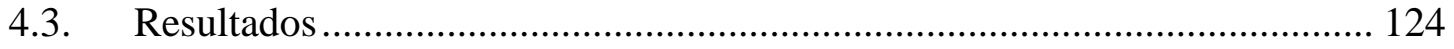

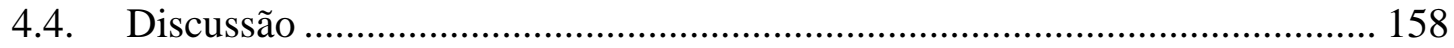

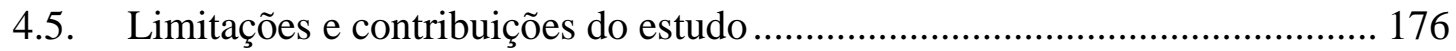

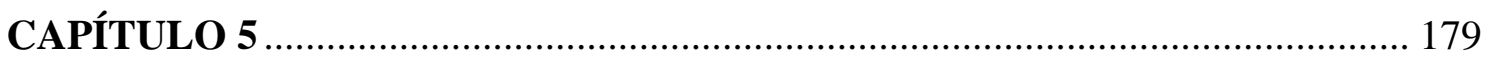

IMPLICAÇÕES DA TESE E CONSIDERAÇÕES FINAIS ............................... 179

5.1. Políticas públicas de prevenção - apontamentos .......................................... 179

5.2. Programas de prevenção - práticas profissionais ...................................... 182

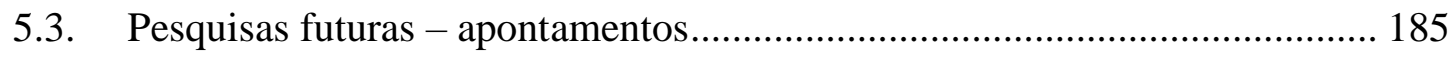

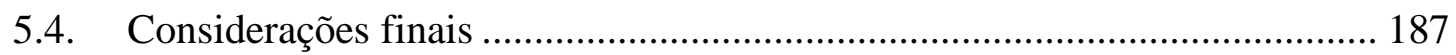

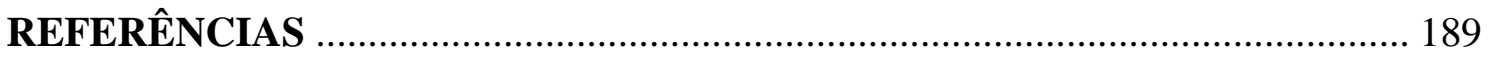




\section{CAPÍTULO 1}

\section{A VIOLÊNCIA CRIMINAL NO BRASIL E OS DESAFIOS IMPOSTOS AO SISTEMA DE JUSTIÇA}

A violência criminal no Brasil representa um problema significativo que afeta, direta ou indiretamente, toda a sociedade, impactando as despesas do estado e o bem-estar pessoal e coletivo. Diante disso, vive-se uma ampla e generalizada sensação de insegurança, em razão do que grande parte da população clama por políticas mais punitivas. O apelo popular se reflete nas práticas institucionais; assim, se observa, ano a ano, aumento no número de indivíduos condenados e submetidos a medidas de restrição e de privação de liberdade, o que abarca a população adolescente e jovem. Essa política, todavia, não se faz acompanhar pela redução nas taxas de crimes e, tampouco, pela diminuição na sensação de insegurança. Em contrapartida, impacta de forma contundente o desenvolvimento pessoal dos indivíduos submetidos a essas práticas, que passam meses ou anos de vida enclausurados em instituições fechadas. É fato que o impacto tende a ser maior e mais negativo nos adolescentes. $\mathrm{O}$ desenvolvimento humano é complexo e, nesta etapa da vida, a intensidade em que os processos biopsicossociais são vivenciados dá peso extra às experiências positivas e negativas que ocorrem nessa fase. Assim, a adequada compreensão e o efetivo enfrentamento do fenômeno da delinquência juvenil requerem lidar com essa complexidade. Para tanto, o conhecimento científico pode/deve auxiliar e ser incorporado na formulação das políticas públicas e nas práticas institucionais, de modo a nortear ações efetivas - eficientes e eficazes -, além de humanizadas, visando reduzir a violência criminal, de forma que indivíduos e coletividades possam desenvolver-se de modo pleno e saudável.

\subsection{A violência criminal no Brasil e o papel dos adolescentes na criminalidade}

Dentre as diferentes formas de violência que assolam o Brasil, destaca-se, aqui, a criminal, entendendo que as cifras de eventos passíveis de serem tipificados como crimes, em nossa sociedade, são bastante elevadas. As taxas de homicídios no país permitem apreender a magnitude do problema. Segundo o Atlas da Violência (Ipea \& Fórum Brasileiro de Segurança Pública [FBSP], 2018), contabilizaram-se 63.880 mortes violentas intencionais (MVI) no ano de 2017, número que representa uma taxa recorde de 31 mortes para cada 100 
mil habitantes, sendo essa maior que a de países envolvidos em conflitos armados como Congo, Iraque, Síria e Sudão. A análise da tendência da taxa de homicídios, nos últimos 10 anos, revela um crescimento - oscilante - desse tipo de morte no país, como mostra a Figura 1.1, na contramão da tendência global, a qual denota uma diminuição constante de 2000 a 2015, quando se registou uma taxa média de 6,4 mortes por 100 mil habitantes (OMS, 2016). Essa estatística classifica o Brasil entre os 10 dos países com taxas de homicídios mais altas no mundo (BRASIL, 2018).

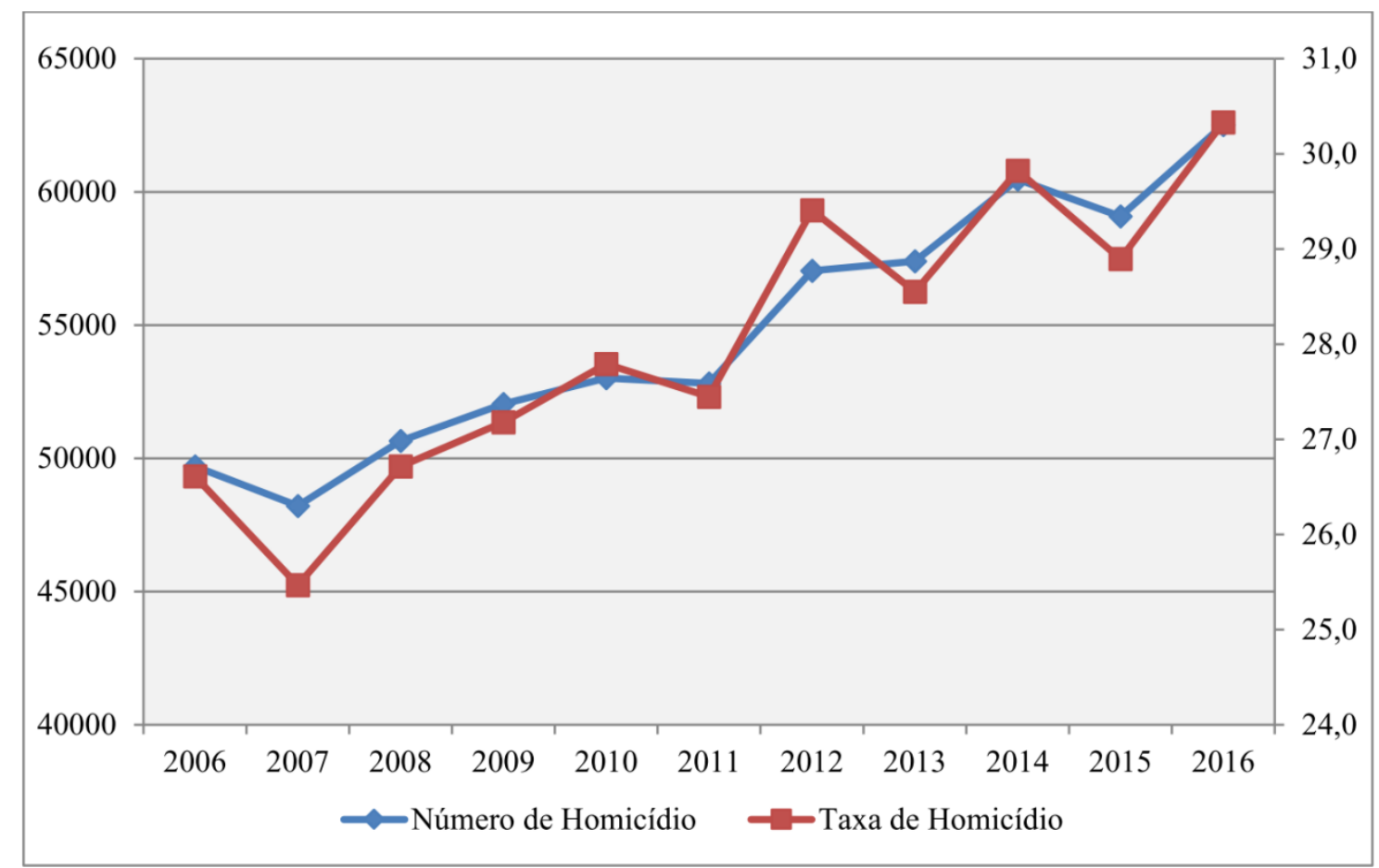

Figura 1.1. Série temporal do número e taxa de homicídios por 100 mil habitantes no Brasil (2006-2016). Fonte: IBGE/Diretoria de Pesquisas. Coordenação de População e Indicadores Sociais. Gerência de Estudos e Análises da Dinâmica Demográfica e MS/SVS/CGIAE - Sistema de Informações sobre Mortalidade - SIM. O número de homicídios foi obtido pela soma das seguintes CIDs 10: X85-Y09 e Y35-Y36, ou seja: óbitos causados por agressão mais intervenção legal. Elaboração Diest/Ipea e FBSP. Figura retirada de: Atlas da Violência 2018 (Ipea \& FBSP, 2018, p. 20).

Afora os homicídios, as taxas conhecidas de outros crimes violentos são também significativas. Com base em dados sistematizados pelas Nações Unidas sobre tendências de delitos, Tobar (2015) oferece informações relacionadas aos países da América do Sul, destacando outros delitos considerados violentos (além dos homicídios), as quais indicam que o Brasil, em 2012, teria contabilizado as seguintes taxas por 100 mil habitantes: 368,9 lesões corporais (ataque físico contra outra pessoa que lhe causa lesões corporais graves), 26,9 violências sexuais (estupro ou agressão sexual), 493,1 roubos (furto dos bens de uma pessoa vencendo sua resistência mediante o uso da força ou a ameaça do uso da força), 191,7 
roubos com invasão (acesso não autorizado a uma parte de um edifício, uma moradia ou outras instalações, inclusive mediante o uso da força, com a intenção de subtrair bens do local) e 0,2 sequestro (retenção ilegal de uma ou mais pessoas contra a sua vontade mediante o uso da força ou ameaças ou fraude).

Para além da materialidade dos danos atrelados à criminalidade violenta, principalmente, tem-se o medo que ela gera e os efeitos que isso produz na sociedade, como o aumento da desorganização social e a redução da qualidade de vida das pessoas (Doran \& Burgess, 2012; Guedes, Moreira, Teixeira \& Cardoso, 2018; Jackson \& Gray, 2010). Estudos sugerem que o medo da violência - reação emocional caracterizada por ansiedade e senso de perigo (Garofalo, 1981) - concorre para a diminuição da coesão entre moradores dos bairros (Alper \& Chappell, 2012; Spelman, 2004) e da confiança entre as pessoas (Garofalo, 1981), propiciando aumento do isolamento social (Ross \& Mirowsky, 2000) em decorrência de comportamentos de esquiva ou de hostilidade frente a desconhecidos (Garofalo, 1981; Simunovic, Mifune \&Yamagish, 2013; Sommerfeldt, 2013), e da desorganização comunitária (Lorenc et al., 2013), o que favorece o uso de mecanismos de controle formal em detrimento do informal (Gibson, Zhao, Lovrich, \& Gaffney, 2002; Samuels \& Judd, 2002). Nesse sentido, a sensação de insegurança muitas vezes produz restrição das liberdades individuais de circular e de acessar os espaços públicos da cidade, um direito estabelecido pelo Estatuto da Cidade (Lei ${ }^{\circ}$ 10.257/2001).

No universo da criminalidade, destaca-se o papel desempenhado pela população juvenil. Apesar de a participação dos adolescentes em crimes violentos estar longe de ter características epidêmicas como, às vezes, creem as pessoas e veicula a grande mídia, é fato que o papel que a população jovem desempenha neste cenário é relevante e merece ser focalizado/estudado. Embora, em termos relativos, possa-se considerar que os adolescentes respondam por apenas uma pequena parcela da violência registrada no Brasil, os dados oficiais revelam que eles têm atuado para o aumento das taxas de crimes violentos, como autores e/ou coautores de crimes (FBSP, 2017). Em 2018, foram expedidas 101.540 guias por 184 modalidades de atos infracionais atribuídas a um total de 96.281 adolescentes, segundo a base de dados do Conselho Nacional de Justiça (CNJ). O número de guias excede ao de adolescentes devido aos jovens que possuem mais de uma guia de infração atribuída à sua autoria. E desse montante de atos registrados, 39.195 (39\%) podem ser atribuídos a atos violentos como ameaça (3.037), roubo (27.729), lesão corporal (408), violência contra a mulher (188), violência sexual (2.234), motim de presos (30), sequestro (138), crime de 
perigo para a vida ou saúde de outrem (24), tortura (62) e homicídio (5.345) ${ }^{1}$. Levando-se em consideração os crimes que não são registrados e os crimes cujos autores não são identificados, essas cifras podem ser ainda maiores.

A esse respeito, mais importante que as taxas relativas e absolutas de crimes praticados por adolescentes, são os desdobramentos do envolvimento desses jovens em práticas delituosas em seu próprio desenvolvimento biopsicossocial e, em termos de organização social, no modo como a sociedade os percebe e fomenta políticas de controle essencialmente repressivas. Como observado pela Associação Nacional dos Centros de Defesa da Criança e do Adolescente (ANCED; 2007), nota-se um movimento no sentido de colocar o jovem, especialmente o adolescente infrator, como fonte principal dos perigos que assolam a sociedade. As percepções distorcidas da realidade, superestimando o risco atribuído aos delitos e/ou ao adolescente infrator, resulta em reações populares favoráveis a políticas públicas ineficazes ou ruins, em geral ligadas a propostas como aumento de aprisionamentos, liberação de armas de fogo, políticas de higienização em relação a minorias, entre outras (Best, 1999; Beckett, 1999; Enns, 2016; Simon, 2007; Stroebe, Leander \& Kruglanski, 2017).

Assim, de um lado, observa-se no Brasil uma crescente preferência por ações de natureza repressiva. O levantamento da CNI (2017) descreve que 75\% das pessoas acreditam que penas maiores reduziriam a criminalidade, $82 \%$ apoiam as Forças Armadas no combate à criminalidade, $69 \%$ são favoráveis à prisão perpétua e $49 \%$ à pena de morte. As opiniões também recaem sobre a população juvenil. Segundo o mesmo relatório, $80 \%$ creem que a maioridade em 18 anos aumenta a participação de menores em crimes e 90\% querem que adolescentes acima de 16 anos que praticarem atos hediondos respondam no sistema penal adulto. Curiosamente, dois estudos realizados no estado de Minas Gerais mostram que a taxa de reincidência no sistema socioeducativo (30\%; Sapori, Caetano \& Santos, 2018) é menor que a taxa de reincidência do sistema penal (51\%; Sapori, Santos \& Wan der Maas, 2017). E em relação aos adolescentes autores de delito de homicídio, constata-se que a taxa de reincidência é de 17\% (Sapori, Caetano \& Santos, 2018), pelo menos metade da taxa de reincidência dos autores de outros delitos como furto (57\%) ou tráfico de drogas (35\%),

\footnotetext{
${ }^{1}$ Roubo $=$ roubo $(8.269)+$ roubo majorado $(15.216)+$ roubo qualificado $(4.244) ;$ Lesão corporal $=$ evasão mediante violência contra pessoa (7) + violência doméstica (401); Violência contra mulher = violência doméstica contra mulher (172) + violência contra mulher (16); Violência sexual = abuso de incapazes (9) + atentado violento ao pudor (39) + assédio sexual (21) + posse sexual mediante fraude (3) + violação sexual mediante fraude (8) + estupro (396) + estupro de vulnerável (1758); Sequestro = sequestro (77) + extorsão mediante sequestro (57) + tráfico de pessoas (4); Homicídio = feminicídio (1) + latrocínio (685), homicídio simples (1.264), homicídio qualificado (3.392), homicídio privilegiado (21) + Homicídio Agravado pelo Extermínio de Seres Humanos (9).
} 
indicando que o ato infracional, tomado isoladamente, pouco informa sobre as características e o engajamento infracional do autor.

Ainda sobre as tomadas de decisões em âmbito da justiça juvenil e da justiça criminal, Komatsu e Bazon (2016) destacam que o número de internações aumentou, assim como o de detentos no sistema prisional adulto (e seguem aumentando segundo o FBSP, 2018), sem que, com isso, houvesse diminuição nas taxas de crimes registrados e da sensação de insegurança. Portanto, a tese de que o aumento de medidas de restrição de liberdade tem potencial para controlar as taxas de crime e aumentar a segurança da sociedade não parece se sustentar. Em números absolutos, um levantamento na base de dados online do Cadastro Nacional de Adolescentes em Conflito com a Lei do Conselho Nacional de Justiça (CNJ) aponta que o número de adolescentes em medida restritiva de liberdade (semiliberdade e internação com ou sem atividades externas) passou de 22.790 em 2014 para 35.368 em 2018, como mostra a Tabela 1.1. O que chama mais atenção nesses números é que as aplicações de medidas socioeducativas de restrição de liberdade (semiliberdade e internação) cresce de forma mais acelerada que as outras medidas socioeducativas (advertência, prestação de serviços à comunidade, reparação de dano e liberdade assistida), 55\% contra $28 \%$ durante o período analisado.

Tabela 1.1.

Número de adolescentes por natureza de medida socioeducativa (2014-2018)

\begin{tabular}{lccccc}
\hline Natureza da Medida & $\mathbf{2 0 1 4}$ & $\mathbf{2 0 1 5}$ & $\mathbf{2 0 1 6}$ & $\mathbf{2 0 1 7}$ & $\mathbf{2 0 1 8}$ \\
Socioeducativa Aplicada & 30.856 & 45.011 & 47.072 & 45.866 & 42.088 \\
\hline Prestação de serviços à comunidade & 507 & 691 & 703 & 760 & 729 \\
Obrigação de reparar o dano & 1.793 & 2.295 & 2.898 & 2.396 & 2.494 \\
Advertência & 33.845 & 47.175 & 48.055 & 46.581 & 40.429 \\
Liberdade assistida & 6.089 & 10.078 & 10.383 & 9.396 & 7.968 \\
Semiliberdade & 12.354 & 16.987 & 17.787 & 17.297 & 18.573 \\
Internação sem atividades externas & 4.347 & 7.935 & 7.930 & 8.734 & 8.848 \\
Internação com atividades externas & 89.791 & 130.172 & 134.828 & 131.030 & 121.129 \\
\hline Total & Fonte: Base de dados do Cadastro Nacional de Adolescentes em Conflito com a Lei do \\
Conselho Nacional de Justiça (versão 1.0.1.18). A consulta foi realizada em 01/01/2019, na qual \\
buscou-se por todas as guias de adolescentes por natureza de medida socioeducativa no período \\
correspondente a 01 de janeiro a 31 de dezembro de cada ano.
\end{tabular}

Por outro lado, na intrincada rede da violência social, autores e vítimas da violência se confundem, sobretudo quando se trata dos jovens. Eles constituem o segmento mais vitimado pelas MVI, ou seja, são as principais vítimas dos homicídios no Brasil, algo que não se observa em nenhuma outra faixa etária (Ipea \& FBSP, 2018). Os dados apresentados no Atlas 
da Violência mostram que as MVI teriam sido as responsáveis por mais de 50\% dos óbitos, na população jovem masculina de 15 a 29 anos, atingindo um pico de $57 \%$ na faixa dos 15 a 19 anos. Focalizando o aspecto racial, os dados mostraram também que a taxa envolvendo a população negra (pretos e pardos) era de 40 para cada 100 mil habitantes, enquanto a taxa envolvendo a população não negra (brancos, amarelos e indígenas) era de 16. Pode-se, portanto, afirmar que as vítimas de MVI no Brasil são majoritariamente homens jovens e negros que, assim, compõem um grupo altamente vulnerável à criminalidade violenta em nosso país.

\subsection{Desafios da justiça juvenil e a contribuição da presente tese}

Em vista à complexidade do desenvolvimento humano, em especial durante a adolescência, as problemáticas na socialização dos jovens merecem um olhar / um entendimento igualmente complexo. Sabe-se que a adolescência é um período em que os comportamentos de risco - incluindo os delituosos - se acentuam, atingindo um pico por volta dos 17 anos e decaindo ao final da adolescência e primeiros anos da vida adulta (Farrington, Piquero \& Jennings, 2013). Estudos em diferentes países tem identificado que mais de $60 \%$ dos adolescentes do sexo masculino cometem algum ato delituoso durante essa fase (Barberet, Bowling, Junger-Tas, Rechea, Arberola \& Zurawan, 2004; Elliott, Ageton, Huizinga, Knowles \& Canter, 1983; Komatsu \& Bazon, 2015; Le Blanc, 2003). Sabe-se também que uma minoria - entre 5\% e 10\% - dos adolescentes deste grupo é responsável por mais da metade dos delitos cometidos, assim como pela maior parte dos delitos mais graves e violentos (Farrington et al., 2006; Komatsu \& Bazon, 2017a; Piquero, 2000), enquanto a maioria deles se restringiria a praticar um ou outro ato delituoso, sem demonstrar um real engajamento infracional (Farrington et al., 2006; Le Blanc, 2003).

As evidências sobre a existência de diferentes níveis de implicação com o crime/delinquência por parte dos adolescentes fomentaram o estudo das "trajetórias delituosoas", sobretudo no campo da chamada Criminologia Desenvolvimental. Nesta perspectiva, a trajetória da conduta delituosa manifesta por um adolescente passou a ser o foco, sendo essa concebida como fruto de uma combinação complexa entre fatores pessoais/desenvolvimentais, relacionais, sociais e culturais. Os estudos de trajetórias propiciaram a proposição da noção de delinquência comum (para referir-se a uma atividade delituosa ocasional, limitada à adolescência) e de delinquência distintiva (para referir-se a 
uma atividade delituosa reiterada, persistente no curso da vida) (Le Blanc, 2003; Moffit, 2018).

A delinquência comum abarca as trajetórias da conduta delituosa de adolescentes que se limitam a um ou outro ato durante esta fase. Esses comportamentos seriam, geralmente (mas nem sempre), de baixa gravidade e emergiriam em razão das circunstâncias, na maior parte das vezes relativas a atividades de lazer na companhia de pares de idade, e não representariam um engajamento infracional preocupante. Já a delinquência distintiva (às vezes nominada como delinquência persistente) abarca as trajetórias da conduta delituosa ditas crônicas, ou seja, trajetórias constituídas pela prática frequente e persistente de delitos ao longo da adolescência e, por vezes, para além desta fase da vida. A delinquência distintiva sinalizaria uma defasagem desenvolvimental importante dos adolescentes, decorrente de uma série de problemas/dificuldades e experiências negativas que se acumulam e se complexificam desde a infância (por vezes até mesmo de condições adversas durante o período pré-natal; Moffitt, 2018). As trajetórias indicativas da delinquência distintiva remeteriam a um elevado engajamento infracional, sendo esse caracterizado pela manifestação da conduta delituosa, em geral, precoce (ou seja, no início da adolescência, ou antes), em alta frequência, polimórfico (ou seja, diversificado), envolvendo, por vezes, delitos de natureza violenta (Le Blanc; 2002; Le Blanc, 2003).

Em contexto brasileiro, Komatsu e Bazon (2017b) estudaram o comportamento delituoso autorrevelado por 60 adolescentes infratores que cumpriam Medida Socioeducativa de liberdade assistida e 133 adolescentes de escolas públicas. Por meio de uma análise de clusters, os adolescentes foram agrupados com base no engajamento infracional aferido pela idade do primeiro delito, diversidade de delitos já praticados e frequência de delitos praticados no último ano. Os autores identificaram cinco agrupamentos com níveis de engajamento infracional significativamente distintos, variando desde a ausência de implicação com delitos (abstêmios) até atividade delituosa com frequência e diversificação elevadas. Um dos achados mais interessantes desse estudo é que, à exceção do "grupo abstêmio" (composto somente por escolares), todos os outros grupos foram compostos por adolescentes escolares e judicializados, propiciando a possibilidade de fazer as seguintes afirmações: parte da amostra dos adolescentes escolares, embora não possuíssem passagem pelo Sistema de Justiça Juvenil, possuíam engajamento infracional equivalente ao dos adolescentes infratores; todos os adolescentes infratores haviam sido submetidos a mesma medida socioeducativa, independentemente de seu nível de engajamento infracional ou de suas necessidades individuais. 
Assim, entende-se que um dos desafios postos à Justiça Juvenil consiste em distinguir, entre os adolescentes que chegam ao Sistema, aqueles cujo comportamento infracional remete a uma delinquência comum, apresentada pela maior parte da população, que dispensa institucionalização e formas de intervenção psicossociais especializadas, e aqueles cujo comportamento remete à delinquência distintiva/persistente, que requerem intervenção especializada. Como destacam Bertini e Estevão (1986), tal distinção contribuiria à dinamicidade do sistema e às políticas públicas na área. Essa ação beneficiaria os próprios adolescentes na medida em que teriam sua necessidade de intervenção jurídica e psicossocial melhor apreendida, para além do delito em razão do qual são apreendidos e trazidos à Justiça. Também beneficiaria aos profissionais que devem tomar decisões sobre o encaminhamento a ser dado aos jovens e aos que devem empreender intervenções de acompanhamento socioeducativo, na medida em que disporiam de mais elementos para raciocinar. Ademais, do ponto de vista institucional, tal distinção certamente geraria uma economia relativa aos custos da intervenção (considerando o número de vagas no sistema socioeducativo) e um aumento na qualidade dos serviços oferecidos (Maruschi \& Bazon, 2014).

Um segundo desafio posto à Justiça Juvenil é o de identificar, em meio aos adolescentes cujo padrão comportamental remete à delinquência distintiva/persistente, aqueles que apresentam maior risco para engajar-se em atos violentos, uma vez que esses requerem maior enquadramento e intervenção ainda mais especializada (Farrington, 1995). Os estudos de trajetória vêm indicando diferenças importantes no desenvolvimento da conduta delituosa persistente, no sentido de identificar a existência de uma trajetória na qual observa-se agravamento em direção à prática de crimes violentos (denominada delinquência persistente maior), em paralelo a outra sem esta característica específica (denominada delinquência persistente menor), o que remete à necessidade de identificar e compreender quais mecanismos psicossociais estão envolvidos nesses processos diferenciados.

No âmbito internacional, há décadas, tem-se investido nesta direção, como retrata o livro do Escritório de Justiça Juvenil e Prevenção da Delinquência, do Departamento de Justiça dos Estados Unidos (Loeber \& Farrington, 1998). Esse relata o trabalho conjunto de 22 pesquisadores da área que, por dois anos, se dedicaram a reunir o conhecimento cientificamente produzido sobre jovens infratores violentos. Uma das conclusões a que chegaram é a de que quanto antes eles forem identificados, maiores as chances de a intervenção ser bem-sucedida. Essa assertiva é verdadeira para a maioria dos tratamentos em saúde e, no que respeita aos adolescentes infratores graves, tem especial importância, tendo 
em vista que esses se mostram menos aderentes e suscetíveis a tratamentos, com o passar do tempo.

Isso posto, a presente tese tem como objeto de estudo o desenvolvimento do comportamento violento na adolescência, especificamente em adolescentes do sexo masculino $^{2}$, e se propõe a contribuir para a produção de conhecimento que seja útil a acadêmicos, técnicos do sistema judiciário e construtores e aplicadores de políticas públicas. Por meio da integração do conhecimento científico produzido no campo e de estudo empírico com adolescentes infratores, esta tese buscou identificar os fatores de risco e de proteção mais relevantes ao desenvolvimento de padrões de conduta delituosa violenta, apresenta um método sistemático para avaliar o risco de engajamento de adolescentes em uma trajetória de delitos que envolva a violência e o aplica em uma amostra de adolescentes infratores. Em alguns países, a avaliação de risco de violência tem sido utilizada, primariamente, nas tomadas de decisão em âmbito jurídico, no que se refere à medida judicial apropriada ao adolescente infrator (Gottfredson \& Tonry, 1987).

\footnotetext{
${ }^{2}$ Há um conjunto de evidências que indicam que os processos desenvolvimentais relacionados à conduta violenta de adolescentes do sexo masculino e do sexo feminino diferem em termos quantitativos e qualitativos (Janssen, Eichelsheim, Deković \& Bruinsma, 2017; Moffitt, Caspi, Rutter \& Silva, 2001), indicando a importância dessa distinção para o objeto de pesquisa em foco. Os estudos utilizados para sustentar a presente tese focalizaram em adolescentes do sexo masculino. A parte empírica aqui apresentada também contou somente com a participação de adolescentes do sexo masculino. Sendo assim, destaca-se que as considerações, os resultados e os apontamentos da presente tese referem-se especificamente a adolescentes do sexo masculino.
} 
36 | A violência criminal no Brasil e os desafios impostos ao sistema de justiça 


\section{CAPÍTULO 2}

\section{MARCO TEÓRICO: A PSICOPATOLOGIA DO DESENVOLVIMENTO}

A conduta delituosa na adolescência e seus determinantes interessa sobremaneira à Psicopatologia Desenvolvimental ${ }^{3}$ (Developmental Psychopathology), abordagem voltada à identificação e à compreensão dos mecanismos subjacentes à manifestação de problemas de saúde mental ou de comportamento. A perspectiva teórico-metodológica da Psicopatologia Desenvolvimental vem sendo intensamente aplicada no campo da Criminologia, dando origem a uma abordagem específica denominada Criminologia Desenvolvimental. Os pesquisadores neste campo buscam identificar os fatores de risco/vulnerabilidade e de promoção/proteção/resiliência associados ao desenvolvimento de padrões de comportamento antissocial $^{4}$, com o objetivo de entender, explicar e modificar o engajamento infracional. Os estudos têm permitido avançar na produção do conhecimento e no entendimento da conduta antissocial e criar hipóteses sobre relações causais (processos causais) entre as variáveis e, com isso, elaborar e/ou aprimorar programas de prevenção primária e secundária mais eficazes para a população jovem, no sentido de favorecer seu pleno desenvolvimento.

\subsection{A Psicopatologia do Desenvolvimento}

Historicamente, a Psicopatologia Desenvolvimental (PD) se organiza enquanto construto na obra de Achenbach (1974) e posteriormente se desenvolve em uma abordagem teórica-metodológica tendo como grandes referências os trabalhos de Rutter e Garmezy (1983), Sroufe e Rutter (1984), Rutter (1985), Cicchetti (1984), Cicchetti e Sroufe (2000), Cicchetti e Cohen $(1995,2006)$ e Cicchetti (2016). A PD é descrita por Cicchetti (2006) como

\footnotetext{
${ }^{3} \mathrm{O}$ termo mais utilizado, em língua portuguesa, para a tradução de "Developmental Psychopathology" é "Psicopatologia do Desenvolvimento". No entanto, também consta na literatura de língua portuguesa a tradução "Psicopatologia Desenvolvimental". Na presente tese os dois termos serão empregados de modo intercambiável.

${ }^{4} \mathrm{Na}$ presente tese, entende-se que o termo "comportamento antissocial" refere-se a uma amplitude de problemas de conduta. Esses comportamentos podem tanto violar a lei (ex: roubo) como não a violar, mas ir contra as regras/costumes de uma determinada sociedade (ex: consumo de álcool por adolescentes) (Fonseca, 2000; Day, Wankly \& Yessine, 2014). Os termos "comportamento delituoso" e "comportamento infracional" serão utilizados para se referir aos considerados crimes, segundo o código penal brasileiro, e o termo "comportamento divergente" será para se referir estritamente aos comportamentos considerados problemas de conduta que não implicam, contudo, em violação de Lei criminal.
} 
uma perspectiva multidisciplinar integrativa sobre "os processos biológicos, psicológicos, sociais e culturais e como a interação entre esses múltiplos níveis de análise podem influenciar as diferenças individuais, a continuidade ou a descontinuidade dos padrões de comportamentos adaptativos ou não adaptativos, e as trajetórias pelas quais os desfechos de desenvolvimento normal ou patológico são alcançados". Seu objetivo final é "explicar o desenvolvimento de padrões individuais de adaptação ou mal adaptação". Embora o próprio autor reconheça que há algumas divergências entre os pesquisadores em relação à delimitação da $\mathrm{PD}$, em termos gerais, as definições convergem, especialmente quanto à importância dada ao aspecto desenvolvimental e ao foco nas diferenças individuais para a compreensão do desenvolvimento de patologias, transtornos ou qualquer outro desfecho.

Uma das consequências de se definir o objetivo e o escopo da PD é que ela passa a se distinguir de disciplinas correlatas. Embora possua aspectos similares, a PD diverge em concepções relevantes tanto da Psicologia do Desenvolvimento quanto da Psiquiatria Infantil. Conforme destacado por Rutter (2008), a Psicologia do Desenvolvimento busca por marcadores universais do desenvolvimento, enquanto a PD busca por diferenças individuais que produzem mudanças no curso do desenvolvimento à medida que as circunstâncias são alteradas. A Psiquiatria Infantil, por sua vez, se concentra nas causas e nas progressões dos diagnósticos individuais. Posto isso, é importante destacar que apesar do emprego do termo "Psicopatologia" - cujas raízes remontam aos estudos iniciais da PD sobre o desenvolvimento de psicopatologias - os conceitos teóricos, delineamentos de pesquisas, métodos de análises e formas de raciocinar que amparam o campo da PD podem ser aplicados ao estudo de qualquer desfecho desenvolvimental, seja ele negativo ou positivo. Na Criminologia, a perspectiva da PD gerou uma corrente específica denominada Criminologia Desenvolvimental, voltada ao estudo do comportamento antissocial, ou especificamente da conduta delituosa (Nagin \& Odgers, 2010). Nessa, os pesquisadores buscam identificar os principais fatores de risco e de proteção associados ao desenvolvimento - a continuidade e a descontinuidade - de padrões de comportamento antissocial, designadamente o engajamento infracional (Bazon, Komatsu, Panosso \& Estevão, 2011; Le Blanc, 2002).

Com base no entendimento de que os padrões adaptativos ${ }^{5}$ e mal adaptativos são possíveis desfechos do desenvolvimento do comportamento, situado no contexto do

\footnotetext{
${ }^{5} \mathrm{O}$ conceito de adaptação empregado pela Psicopatologia do Desenvolvimento difere do termo utilizado no campo da Biologia Evolutiva. Na Biologia, a seleção natural filtra os traços que favorecem a sobrevivência e o sucesso reprodutivo, selecionando os indivíduos mais adaptados a determinado ecossistema. Na PD, o termo adaptativo é geralmente empregado para designar comportamentos que promovem o bem-estar do indivíduo e
} 
desenvolvimento humano, há seis importantes assunções da PD que merecem destaque. A primeira refere-se à noção de continuidade no processo de desenvolvimento, de modo que o efeito de experiências prévias é levado adiante ao longo do desenvolvimento (Polanczyk, 2009; Rutter, 1979; Rutter, 2008). Nesse sentido, o efeito de uma ou outra experiência estressora muitas vezes é insuficiente para produzir um desenvolvimento atípico, em virtude do que se salienta a importância do efeito cumulativo de variados eventos adversos, seja pela cronicidade seja pela gravidade desses, e de sua incidência no curso de vida do indivíduo. Por exemplo, no estudo de Stoddard, Zimmerman e Bauermeister (2012), no qual 750 adolescentes estadunidenses foram acompanhados por quatro anos, identificou-se que a curva de crescimento do número de fatores de risco era acompanhada pela curva de crescimento de comportamentos violentos, ou seja, para cada fator de risco a mais a que os jovens estavam expostos, com o passar dos anos, maior a frequência dos comportamentos manifestados violentos por eles, ao passo que para cada fator de risco a menos, menor as chances de manifestação desses comportamentos.

A segunda refere-se à tendência inata de os indivíduos se adaptarem ao seu ambiente, o que significa dizer que se o ambiente for "patológico" (disfuncional), aumentam as chances de a adaptação também ser patológica (Duntley \& Buss, 2011; Komatsu, Costa \& Bazon, 2018; Polanczyk, 2009). Nesses casos, os mecanismos de adaptação empregados pelo indivíduo produzem um desajuste emocional, psicológico ou social. Os estudos mostram que indivíduos imersos em ambientes conturbados como, por exemplo, uma criança ou um adolescente vivendo em uma família chefiada por adultos que possuem estilos parentais inadequados, residindo em um bairro com altas taxas de criminalidade, estão mais em risco de desenvolverem transtornos ou manifestarem comportamentos antissociais (Van de Weijer, Augustyn \& Besemer, 2017; Wadsworth, 2015). No caso do comportamento violento, seu desenvolvimento poderia ser explicado por três mecanismos: pelo contra-controle, no qual o indivíduo responde a ambientes ou a situações hostis, se comportando de forma igualmente hostil; por modelagem (uso da violência para obtenção de reforços); por modelação (imitação) de comportamentos violentos em razão de sua exposição a modelos desviantes. Quando a conduta violenta é integrada ao repertório de comportamentos do indivíduo, ela pode passar a ser utilizada com mais frequência e/ou ser generalizada a outros ambientes, mesmo naqueles em que a violência não é necessária, nem aceitável.

seu ajuste à sociedade, sem que necessariamente impliquem sobrevivência ou sucesso reprodutivo (Frankenhuis $\&$ Del Giudice, 2012). 
A terceira estabelece que o estágio desenvolvimental - geralmente aferido pela idade, porém não restringido a ela - contribuí de maneira única à organização das experiências passadas, à assimilação e à acomodação das experiências presentes, e à direção do desenvolvimento, influenciando o futuro de cada indivíduo (Cicchetti, 2006). Komatsu, Costa e Bazon (2018) destacam que as inúmeras e intensas transformações em curso, na adolescência, apresentam-se como uma janela de oportunidades, pois propiciam o desenvolvimento de aptidões e a aquisição de competências mais facilmente e mais rapidamente. Assim, de um lado, se os estímulos ambientais existem e são adequados, o adolescente faz aquisições que lhe permitirá lidar de modo cada vez mais competente com as complexas demandas psicossociais. De outro lado, se os estímulos ambientais não existem ou são inadequados, haverá defasagens/déficits que perpassarão sua adaptação psicossocial, concorrendo para a emergência de problemas de comportamento e, até mesmo, transtornos mentais. Sem a estimulação adequada, o desenvolvimento dos circuitos neurais pode sofrer um atraso, limitando as capacidades executivas do adolescente e aumentando sua dificuldade em responder apropriadamente às demandas sociais (Komatsu, Costa \& Bazon, 2018). Por conseguinte, a adolescência, enquanto estágio desenvolvimental, é tida também como um período sensível e por isso é considerada uma etapa crucial para compreender o surgimento e o desenvolvimento de problemas psicossociais relevantes.

A quarta premissa inerente à PD assinala que o desenvolvimento neurobiológico estrutura e funcionamento do sistema nervoso - afeta o comportamento, mas também é, em si, afetado pelas experiências de vida. Os estudos demonstram que experiências psicológicas e sociais podem modificar a expressão gênica e alterar a estrutura, a organização e o funcionamento do cérebro e das conexões neurais (Kandel, 1998, 1999, 2013). Esse ponto é especialmente importante para entender a trajetória de indivíduos considerados difíceis de lidar na convivência social. Sabe-se que o temperamento ${ }^{6}$ assenta-se em bases biológicas e tem, assim, um forte componente genético. Estudos mais recentes mostram que alguns traços manifestos durante a infância predizem diferenças individuais no desenvolvimento de psicopatologias (Buss \& Plomin, 2015; Papageorgiou \& Ronald, 2017). Assim, crianças com “temperamento difícil”, associado, por exemplo, à impulsividade marcada, tendem a ser disruptivas e a causar problemas em algumas situações sociais, sendo, desde cedo, rotuladas como difíceis e, frequentemente, castigadas por isso, de forma que as interações sociais são

\footnotetext{
${ }^{6}$ Temperamento se refere à "natureza emocional de um indivíduo, incluindo sua suscetibilidade à estimulação emocional, suas forças habituais e velocidade de resposta, a seu humor predominante e as peculiaridades, flutuações e intensidade de seus humores; são esses fenômenos considerados como constitucionais do indivíduo e, portanto, de origem predominantemente hereditária" (Allport, 1937, p. 54).
} 
para elas mais negativas que positivas, gerando ansiedade e frustração, de modo que as características de funcionamento inicial, negativas, intensificam-se. Em contraposição, crianças com "temperamento fácil", associado a traços mais dóceis, podem despertar maior disposição de proximidade e de cuidado por parte dos adultos, resultando em maior estimulação positiva. Esses exemplos ilustram como a vida social pode favorecer alguns traços e desfavorecer outros. Portanto, as experiências de vida podem modificar (intensificar ou atenuar) a expressão das características associadas ao temperamento dos indivíduos, o que concorre para influenciar as trajetórias de indivíduos, conhecimento importante que precisa ser considerado nos programas de prevenção e de intervenção dos problemas de comportamento.

A quinta assunção remete à constatação de que subgrupos de indivíduos que manifestam problemas similares num ponto de suas trajetórias podem ter alcançado essas condições por meio de trajetórias distintas - concepção atinente ao conceito de equifinalidade; e de que um único fator ou um conjunto de fatores pode conduzir a uma grande variedade de desfechos - conceito atinente ao conceito de multifinalidade (Cicchetti \& Rogosch, 1996). Os conceitos de equifinalidade e de multifinalidade ressaltam, mais uma vez, a importância das características individuais para explicar o desenvolvimento de psicopatologias ou de problemas de comportamento. Nessa linha de raciocínio, Le Blanc (1997) ressalta que as características gerais de uma sociedade, ou seja, os fatores macrossociais, são relevantes para explicar as taxas de crime, de modo que compõem um background que pode favorecer ou desfavorecer a manifestação de determinados crimes nesta sociedade; mas são os fatores relacionais e individuais que podem explicar porque somente um certo número de pessoas, nesta mesma sociedade, pratica crimes e envolve-se em atos violentos.

Por fim, a sexta assunção salienta que os conceitos de adaptação e de mal adaptação devem ser interpretados considerando-se o contexto sociocultural, assim como o histórico de experiências e o nível de organização e o funcionamento biológico e psicológico do indivíduo (Cicchetti, 2006; Lewis, 2014). Por exemplo, um certo nível de agressividade pode ser necessário para ser bem-sucedido na prática de determinados esportes, mas não nas relações entre casais. A cultura também exerce influência na forma pela qual os sintomas são manifestados. Como observado por Cicchetti (2006), valores, crenças e práticas culturais tendem a reprimir manifestações de problemas em certos domínios e tolerar ou mesmo fomentar em outros. Por exemplo, a cultura de muitos países é mais tolerante a problemas de 
comportamentos externalizantes em meninos do que em meninas e, ao revés, a problemas internalizantes em meninas, mas não em meninos.

Esses aspectos reforçam a ideia de que o processo de desenvolvimento dos padrões comportamentais é específico, de modo que os mecanismos causais têm resultados diferentes conforme o momento desenvolvimental do indivíduo e suas histórias de adaptação e do contexto social e cultural em que o indivíduo está inserido, assumindo-se, assim, que padrões de comportamento similares podem ser considerados adaptativos em alguns contextos e mal adaptativos em outros. Utilizar a PD para estudar o desenvolvimento da conduta violenta na adolescência implica verificar as experiências anteriores, como essas influenciam o presente, como explicam o padrão comportamental manifesto, e como predizem o desenvolvimento subsequente até a vida adulta.

Assim, entende-se que o desenvolvimento da conduta violenta é causado por fatores de risco que se apresentam em diferentes fases da vida: no período pré-natal (ex.: hábito de a mãe fumar durante a gravidez), na infância (ex.: maus-tratos), na adolescência (ex.: pares infratores) e na vida adulta (ex.: psicopatologia). Esses fatores também podem ser de diferentes níveis: genéticos (ex.: temperamento impulsivo), cognitivos (ex.: dificuldade de aprendizado), psicológicos (ex.: crenças e atitudes hostis), relacionais (ex.: modelos violentos em casa), sociais (ex.: baixa renda) e culturais (ex.: comunidade que valoriza a violência como forma de resolver conflitos). Dessa forma, hipotetiza-se que o comportamento violento se desenvolve tendo por base os efeitos de vários fatores de risco que se acumulam ao longo do tempo para um mesmo indivíduo, mediante a carência de fatores de proteção, em um contexto específico que proporcionará a manifestação da conduta violenta.

\subsection{Fator de risco, fator de promoção, fator de proteção e resiliência: definições}

O principal foco de investigação da Criminologia Desenvolvimental - ou da PD aplicada aos comportamentos antissociais - tem sido os fatores que interferem de forma significativa no curso do desenvolvimento e que possam explicar por que algumas pessoas desenvolvem um padrão de comportamento antissocial e de conduta violenta, e outras não. Esses fatores são chamados de risco, de proteção ou de promoção, dependendo de como interferem aumentando ou diminuindo - a probabilidade de o indivíduo manifestar comportamentos antissociais. 
A maioria dos estudos criminológicos tem focalizado os fatores de risco em detrimento dos fatores protetivos, construindo o que veio a se chamar de paradigma da redução dos fatores de risco (Farrington, 2000). A ideia básica desse paradigma consiste em identificar os fatores de risco associados à conduta delituosa e delinear estratégias para anulálos ou reduzi-los. Fator de Risco tem sido definido como uma característica, experiência ou evento que aumentam as chances de um indivíduo desenvolver uma condição, comparado a outros indivíduos não estão expostos às mesmas condições (Kraemer, Kazdin, Offord, Kessler, Jensen \& Kupfer, 1997). O fator pode ser mensurado de forma categórica (ex: rendimento escolar bom ou ruim) ou contínua (ex: rendimento escolar variando de 0 a 10). Kraemer, Kazdin, Offord, Kessler, Jensen e Kupfer (1997) estabelecem que para demonstrar que uma variável é "de risco" ela precisa ser mensurada em uma população que não possui a condição clínica focalizada (ex: comportamento violento) e distinguir indivíduos que subsequentemente desenvolvem tal condição dos indivíduos que não a desenvolvem. Contudo, a mera significância estatística não é suficiente para concluir que uma variável é de risco, uma vez que em uma amostra suficientemente grande qualquer variável pode se mostrar estatisticamente significativa. Para isso, Kraemer e colegas (1997) listam cinco requisitos para estabelecer que uma determinada variável é um fator de risco para um dado desfecho mal adaptativo:

- A variável desfecho deve ser claramente definida e mensurada de forma válida e confiável;

- A população (universo) e a amostra devem ser claramente definidas;

- A variável explanatória (fator de risco) deve ser claramente definida e deve ocorrer temporalmente antes da variável de desfecho;

- Procedimentos de análise devem ser utilizados para distinguir adequadamente grupos de alto risco de grupos de baixo risco;

- Procedimentos de análise devem ser utilizados para garantir que a diferença entre os grupos de alto risco e os grupos de baixo risco possuam algum significado prático.

Nesse sentido, mais do que garantir a correlação entre duas variáveis, a denominação "fator de risco" deve ser atribuída apenas àquelas que possuírem uma ligação causal - por via direta ou indireta - à condição clínica de interesse, considerando-se também a pertinência teórica e prática do raciocínio que decorre desta ligação. Por esse motivo é importante que 
haja uma teoria que ampare e dê significado à associação estatística entre as variáveis. Ao contrário, pode-se chegar a conclusões sem sentido, baseado em relações espúrias.

Adicionalmente ao conceito de fator de risco, os pesquisadores têm identificado fatores ou marcadores de vulnerabilidade. Vulnerabilidade tem sido definida como condições que aumentam o efeito de um fator de risco (Luthar, 2006). Por exemplo, no estudo de Newsome, Vaske, Gehring e Boisvert (2016), identificou-se que o sexo masculino consiste em um marcador de vulnerabilidade para diversos fatores de risco ambientais, uma vez que meninos tendem a ser mais negativamente influenciado por esses fatores do que as meninas. Assim, embora muitos estudos misturem os conceitos de fator de risco e de vulnerabilidade, este último, sozinho, não aumenta as chances de um desfecho negativo, mas acompanhado do fator de risco potencializam os efeitos deste sobre o indivíduo considerado vulnerável.

Em uma lógica inversa a de fator de risco, tem-se discutido a existência de Fatores de Promoção, definidos como característica, experiência ou evento que diminuem as chances de um indivíduo desenvolver uma condição, comparado a outros indivíduos da mesma população não expostos ao mesmo fator (Farrington, Ttofi \& Piquero, 2016). Como observado por Farrington, Ttofi e Piquero, os fatores de risco e de promoção são, muitas vezes, lados da mesma moeda. Algumas variáveis são consideradas de risco em um extremo (ex: fraco vínculo familiar) e de promoção em outro (ex: forte vínculo familiar), sendo por isso chamadas de variáveis de Risco e de Promoção (ou mistas). Contudo, uma variável pode ser exclusivamente de Risco ou exclusivamente de Promoção, quando sua presença apenas aumenta ou apenas diminui as chances de manifestação do desfecho mal adaptativo focalizado. Como consequência dessa definição, não há interação entre um fator de risco e um fator de promoção, pois ou eles, por vezes, se referem a uma mesma variável ou, por vezes, são exclusivos.

Diferencialmente, tem-se também o conceito Fator de Proteção como uma variável que interage com o fator de risco, anulando seu efeito (fator de proteção interativo) ou diminuindo seu efeito (fator de proteção risk-based), conforme ressaltam Farrington e colegas (2016). Dessa forma, quando um fator de proteção interativo está presente, a probabilidade de manifestação do desfecho, mediante a presença do fator de risco, não aumenta; quando o fator de proteção interativo está ausente, o fator de risco incrementa a probabilidade do desfecho mal adaptativo. Quando um fator de proteção risk-based está presente em um grupo de risco, a probabilidade do desfecho nesse grupo é menor quando comparado a outro grupo igualmente exposto ao mesmo nível de risco. Por exemplo, no estudo de Komatsu, Wenger, Costa, Bazon e Andrés-Pueyo (2019) verificou-se que adolescentes em conflito com a lei para 
os quais se contavam seis fatores de proteção apresentaram uma taxa de reincidência de $26 \%$, ao passo que aqueles para os quais se contava apenas três fatores de proteção apresentaram uma taxa de $48 \%$ e aqueles para os quais não se contava nenhum fator apresentaram uma taxa de 59\%. Focalizando a reincidência em delitos violentos, as taxas foram, respectivamente, $11 \%, 26 \%$ e $35 \%$. Considerando que o número de infrações não diferia significativamente entre os grupos de adolescentes (formados em função do número de fatores proteção) e que o número de fatores de risco a que estariam expostos foi controlado, o estudo monstra a importância dos fatores protetores na redução da delinquência e da violência.

Nesse sentido, apesar do domínio do paradigma de prevenção baseada na redução/eliminação do risco, no campo da Criminologia Desenvolvimental, há um corpo crescente de estudos fomentando a discussão sobre a importância de se focar os fatores protetores (Farrington et al., 2006; Glowacz \& Born, 2015; Komatsu, Wenger, Costa, Bazon \& Andrés-Pueyo, 2019; Rutter \& Giller, 1983; Smith, Lizotte, Thornberry \& Krohn, 1995). Esses mostram que indivíduos, mesmo expostos a numerosos fatores de risco, se adaptam de forma positiva. A explicação para essas diferenças individuais seria a presença dos fatores protetores, por meio dos quais se desenvolveria a resiliência. Para Pollard, Hawkins e Arthur (1999), focar nos fatores protetores para aumentar a resiliência dos jovens promove uma abordagem mais positiva e mais atrativa para indivíduos e comunidades que o paradigma da redução dos fatores de risco, que enfatiza déficits e problemas.

A resiliência refere-se a uma adaptação positiva frente a condições adversas ou traumáticas que geralmente produzem a mal adaptação (Luthar, Cicchetti \& Becker, 2000; Masten, Best \& Garmezy, 1990). Segundo Luthar (2006), a resiliência em si não é passível de ser mensurada diretamente, sendo, portanto, inferida com base em suas duas subdimensões: a adaptação positiva e as condições adversas. As condições adversas são definidas em termos probabilísticos, como condições de alto risco que se fazem acompanhar por altas chances de mal adaptação em domínios críticos (Masten, 2001). Adaptação positiva remete a uma adaptação substancialmente melhor que a esperada dada a exposição a tais circunstâncias adversas, podendo ser mensurada pela manifestação de comportamentos relativos a competências sociais e de autorregulação emocional (Luthar, 2009; Masten, 2001).

Em oposição ao comportamento delituoso/violento, a adaptação positiva seria um estilo de vida pró-social, de acordo com o que é esperado para o estágio desenvolvimental e o contexto sociocultural em que o indivíduo se encontra. As condições adversas seriam os fatores de risco cumulativos relacionados ao ambiente ou às circunstâncias de vida, como a exposição à violência, a associação a pares infratores, a desorganização familiar e outras 
variáveis suscetíveis a impactar negativamente o desenvolvimento e de aumentar a probabilidade de um indivíduo cometer delitos (Komatsu \& Bazon, 2018, Loinaz, AndrésPueyo y Pereira, 2017). Os fatores protetores seriam aqueles suscetíveis de favorecer o desenvolvimento de capacidades que melhoram a resposta do indivíduo em um meio adverso, diminuindo a probabilidade de ele se engajar em atividade delituosa ou em violência (Komatsu et al., 2019; Luthar, 2006).

Ao perceber que nem todas as crianças e adolescentes em alto risco desenvolvem a condição correspondente ao risco, os pesquisadores se interessaram em identificar fatores particulares desses indivíduos (Cicchetti \& Curtis, 2006; Luthar, 2006). Dessa forma, a pesquisa sobre resiliência se desenvolveu para suplantar uma lacuna do paradigma da prevenção do risco, de modo que o conhecimento sobre os processos de resiliência em circunstâncias específicas de risco tornou-se fundamental para sinalizar os fatores que merecem mais atenção em cada condição de risco em particular. Em termos de prevenção primária e secundária, se faz necessário priorizar os domínios "de proteção" mais relevantes com relação à possibilidade de gerar benefícios substanciais ao indivíduo (Luthar \& Zelazo, 2003). Nesse sentido, Luthar (2006) propõe cinco critérios para identificar os fatores de proteção mais relevantes, suscetíveis de gerar resiliência:

- Devem ser conceitualmente mais salientes ou se relacionar mais fortemente ao risco em particular;

- Devem ser relativamente maleáveis ou responsivos a intervenções ambientais;

- Devem ser proximais ao indivíduo, em detrimento dos distais;

- Devem produzir efeitos mais duradouros na vida do indivíduo;

- Devem ter potencial para gerar outros ganhos, catalizando as forças e mitigando as vulnerabilidades.

Um exemplo genérico que cumpre todos os critérios acima e poderia ser aplicado à prevenção é a "educação de alta qualidade", na infância, especialmente em comunidades mais vulneráveis. A educação cumpre o critério de saliência, relacionando-se a vários resultados positivos na vida; é passível de intervenções externas; afeta diretamente a criança; e produz efeitos duradouros e promove a aquisição de outras habilidades psicológicas, cognitivas e sociais (Luthar, 2009). 


\subsection{Fatores de risco e de proteção relacionados ao engajamento infracional envolvendo condutas delituosas violentas: revisão sistemática da literatura}

Inúmeras pesquisas, com perspectiva desenvolvimental, se dedicaram a identificar fatores de risco e de proteção associados à manifestação e à manutenção da conduta delituosa, em adolescentes, e especificamente às condutas violetas. O presente tópico apresenta o trabalho de revisão sistemática da literatura relativa a essa produção científica recente. Para tal, adotou-se o seguinte procedimento de execução: 1) formulação da questão norteadora para a revisão; 2) seleção das bases de dados; 3) definição da estratégia de busca; 4) procedimentos de coleta e de seleção de dados; 5) análise e apresentação dos resultados; 6) interpretação dos dados e apresentação da revisão sistemática.

Formulação da questão norteadora. A questão norteadora foi formulada a partir do modelo P-V-O: P (participantes/contexto/situação-problema), V (variáveis em estudo) e O (desfechos/resultados da busca), segundo protocolo descrito pela Biblioteca Virtual de Saúde (BVS, s.d.). Assim, a pergunta norteadora deste estudo foi: Quais variáveis (preditores) possuem relação proximal e relevância teórica e prática com relação à conduta delituosa violenta na adolescência? Os componentes do modelo PVO possuíram a seguinte estrutura: $\mathrm{P}$ - adolescentes da população que foram entrevistados/avaliados em dois ou mais períodos da vida; V - condutas delituosas violentas; O - identificação de variáveis independentes/preditoras, antecedentes ao envolvimento em condutas delituosas violentas.

Seleção da base de dados. O levantamento se deu na plataforma Web of Science, que consiste em um sistema de buscas que envolve diversas bases de dados e que cobre um amplo espectro de periódicos (mais de 20 mil com avaliação por pares) multidisciplinares e mais de 100 mil livros (Clarivate Analytics, 2019).

Estratégia de busca. Considerando a questão norteadora, utilizou-se os seguintes termos de busca: ((violen*) AND (delinquen* OR offen*) AND (longitudinal)) e se restringiu a selecionar os artigos dos últimos três anos (2016, 2017 e 2018) em todos os idiomas disponíveis. Adicionalmente, pela relevância de alguns materiais que não se encontram nesse tipo de base de dados, se incluiu nas análises protocolos de Avaliação de Risco de Violência (ARV) mais utilizados no mundo, segundo a revisão de Singh e colegas (2014). Como condição de inclusão de estudos no presente levantamento, levou-se em conta os critérios de relevância propostos por Luthar (2006), verificando os fatores com maiores efeitos identificados por revisões sistemáticas anteriores (Hawkins et al., 2000; Komatsu \& Bazon, 
2018; Lipsey \& Derzon, 1998). De modo complementar, levou-se em consideração os critérios propostos por Kraemer e colegas (1997) para estabelecer o efeito entre as variáveis independentes e dependente, selecionando estudos com as seguintes características: variável dependente se referia a alguma modalidade de conduta delituosa violenta; amostra composta por crianças ou adolescentes da população; delineamento de pesquisa longitudinal, de modo a garantir que o fator explanatório precedia a variável de interesse - a conduta delituosa violenta.

Procedimentos de coleta e seleção de informações. A busca dos artigos nas bases de dados ocorreu no mês de dezembro de 2018. A triagem foi realizada por dois pesquisadores independentes, por meio da leitura de títulos e resumos identificados no cruzamento dos descritores utilizados na estratégia de busca, considerando a questão norteadora da revisão e os critérios de inclusão previamente estabelecidos. Na segunda etapa, os pesquisadores recuperaram e leram na íntegra os trabalhos selecionados e buscaram as informações disponíveis em relação à razão de chances (Odds Ratio [OR]) relacionadas à população exposta à variável preditora e à população não exposta à variável preditora. Os estudos em que as informações disponíveis eram o Beta (em vez de OR) e o intervalo de confiança (em vez do erro padrão), os valores foram transformados calculando-se o exponencial do Beta e dividindo-se o intervalo de confiança de $95 \%$ por 3,92. As informações foram armazenadas em uma planilha digital contendo as seguintes informações: autores, ano do estudo, país onde o estudo foi desenvolvido, número de participantes, variáveis mensuradas e os respectivos instrumentos, OR e erro padrão.

Análise e apresentação dos resultados. Os estudos foram analisados de modo quantitativo e qualitativo. Na primeira etapa realizou-se metanálises para combinar o efeito dos estudos e obter um resultado de evidência mais robusta, na qual o efeito de medida utilizado para a análise foi o OR entre participantes expostos e não expostos às variáveis/condições preditoras, utilizando-se como medida de variabilidade o erro padrão. A metanálise foi realizada quando o número de estudos sobre um mesmo construto (fator preditor) era igual ou superior a três. Ressalta-se que um construto pode ser formado por diferentes variáveis/indicadores (por exemplo, o autocontrole é um construto que abarca outros como impulsividade ou controle da raiva). As análises foram realizadas utilizando-se a função rma.uni() do pacote estatístico Metafor (Viechtbauer, 2010) do software R, versão 3.5.1. A avaliação da heterogeneidade entre os estudos e sua magnitude foi realizada mediante os testes $Q$ de Cochran e o índice $I^{2}$. As porcentagens de referência para a heterogeneidade, considerando-se o índice $I^{2}$, foram: próximas de $25 \%$ (baixa), próximas de $50 \%$ (moderada) e 
próximas de 75\% (alta) (Higgins \& Thompson, 2002). Os resultados foram apresentados em gráficos de floresta (forest plot), nos quais as medidas apresentadas foram os logaritmos dos OR. Na segunda etapa, os estudos foram analisados de forma descritiva e crítica, buscando relacionar as variáveis preditoras ao engajamento em delitos violentos por meio da relação teórica e empírica.

O levantamento resultou em 395 estudos, dos quais 34 foram selecionados seguindo os critérios de inclusão acima indicados. Esses estudos abarcaram 229 fatores explanatórios 176 de risco e 53 de proteção - e um total de 2.538 .730 participantes de 10 países distribuídos entre os continentes América do Norte (Estados Unidos), Ásia (Coréia do Sul), Europa (Alemanha, Dinamarca, Espanha, Finlândia, Holanda, Reino Unido, Suécia) e Oceania (Austrália). Os dois tópicos a seguir destacam os principais resultados dessa revisão.

\subsubsection{Os fatores de risco para a conduta violenta}

Os fatores de risco apresentados nesta seção foram agrupados em três categorias históricos, pessoais e contextuais. Os Fatores de Risco Históricos consistem em experiências - passadas - e, portanto, não suscetíveis a mudanças. Esses fatores são levados em consideração em todos os protocolos de ARV devido às evidências empíricas que demonstram sua forte associação à conduta delituosa e à reincidência violenta. Apesar de serem estáticos, considera-se que podem ser focalizados em intervenções visando o significado que tem na vida do indivíduo, de modo que a ressignificação dos eventos ou das experiências conduza a uma diminuição e até a uma anulação de seus efeitos negativos, no presente. Em relação aos fatores históricos, três subcategorias foram identificadas: experiências estressoras, histórico de problemas de comportamento e fracasso em intervenções anteriores.

No conjunto de experiências estressoras, destaca-se o fator exposição à violência enquanto testemunha ou enquanto vítima. Estudos indicam que crescer em um bairro com altas taxas de criminalidade aumenta a probabilidade de se envolver com o crime (Patchin, Huebner, McCluskey, Varano \& Bynum, 2006; Salzinger, Ng-Mak, Feldman, Kam \& Rosario, 2006). Outros estudos, entretanto, mostram que a maioria das crianças que crescem em bairros criminalizados não apresentam engajamento infracional (Chen, Voisin \& Jacobson, 2013). A incompatibilidade entre esses dois dados deve-se, aparentemente, aos sentidos dados ao construto de "exposição à violência". O fato de crescer em um bairro com altas taxas de crime, por si só, não implica qualquer relação de causalidade com o 
engajamento infracional, por isso a maioria das crianças criadas nesses ambientes se desenvolvem normalmente. Contudo, em um bairro com altas taxas de criminalidade, para determinados subgrupos, pode significar oportunidades aumentadas de se associar a pares desviantes e de testemunhar atos violentos ou de ser vítima deles. Assim, a exposição à violência também produz um efeito estressor que pode impactar negativamente o desenvolvimento psicológico, aumentando as chances de transtornos mentais, para determinados indivíduos, o que contribuí para o seu desajuste frente às demandas sociais (Braga, Gonçalves, Basto-Pereira \& Maia, 2017; Hong, Huang, Golden, Patton \& Washington, 2014). A Tabela 2.1 mostra as características dos 11 estudos revisados que estudaram a exposição ao risco e a Figura 2.1 indica uma chance de 2,4 vezes maior de um indivíduo exposto à violência apresentar comportamento violento em período subsequente, comparado a indivíduos não expostos.

Tabela 2.1

Características dos estudos sobre exposição à violência

\begin{tabular}{|c|c|c|c|c|c|}
\hline Autores & $\begin{array}{l}\text { Estudo } \\
\text { (País) }\end{array}$ & Idade & n & V.I. & V.D. \\
\hline $\begin{array}{l}\text { Espelage } \\
\text { et al. } 2018\end{array}$ & EUA & $\begin{array}{l}10-1 \text { e } \\
12-16 \\
\text { anos }\end{array}$ & 1655 & $\begin{array}{c}\text { Vitimização por pares } \\
\text { (Illinois Victimization } \\
\text { Scale; Espelage \& Holt, } \\
\text { 2001) }\end{array}$ & $\begin{array}{c}\text { Agressão Relacional } \\
\text { (Relational Aggression } \\
\text { Scale; Crick, 1996) }\end{array}$ \\
\hline $\begin{array}{l}\text { Niño et al. } \\
2017\end{array}$ & $\begin{array}{l}\text { Add Health } \\
\text { study (EUA) }\end{array}$ & $\begin{array}{c}12-13 \text { e } \\
17-18 \\
\text { anos }\end{array}$ & 10665 & $\begin{array}{l}\text { Vitimização (autoinforme } \\
\text { por questionário) }\end{array}$ & $\begin{array}{c}\text { Delinquência violenta } \\
\text { (autoinforme por } \\
\text { questionário) }\end{array}$ \\
\hline $\begin{array}{l}\text { McCuddy } \\
\quad \& \\
\text { Esbensen, } \\
2017\end{array}$ & $\begin{array}{c}\text { Gang } \\
\text { Resistance } \\
\text { Education } \\
\text { and Training } \\
\text { (USA) }\end{array}$ & $\begin{array}{l}12-15 \\
\text { anos }\end{array}$ & 3271 & $\begin{array}{l}\text { Vítima de cyberbullying } \\
\text { (autoinforme por } \\
\text { questionário) }\end{array}$ & $\begin{array}{c}\text { Delinquência violenta } \\
\text { (autoinforme por } \\
\text { questionário) }\end{array}$ \\
\hline $\begin{array}{l}\text { McCuddy } \\
\& \\
\text { Esbensen, } \\
2017\end{array}$ & $\begin{array}{c}\text { Gang } \\
\text { Resistance } \\
\text { Education } \\
\text { and Training } \\
\text { (USA) }\end{array}$ & $\begin{array}{l}12-15 \\
\text { anos }\end{array}$ & 3271 & $\begin{array}{c}\text { Vítima de bullying } \\
\text { tradicional (autoinforme por } \\
\text { questionário) }\end{array}$ & $\begin{array}{c}\text { Delinquência violenta } \\
\text { (autoinforme por } \\
\text { questionário) }\end{array}$ \\
\hline $\begin{array}{l}\text { Gehring \& } \\
\text { Vaske, } \\
2017\end{array}$ & $\begin{array}{l}\text { Add Health } \\
\text { study (EUA) }\end{array}$ & $\begin{array}{c}11-19 \\
\text { anos até } \\
12-20 \\
\text { anos }\end{array}$ & 9602 & $\begin{array}{l}\text { Violência em } \\
\text { relacionamento } \\
\text { heterossexual }\end{array}$ & $\begin{array}{c}\text { Delinquência violenta } \\
\text { (autoinforme por } \\
\text { questionário) }\end{array}$ \\
\hline $\begin{array}{l}\text { Gehring \& } \\
\text { Vaske, } \\
2017\end{array}$ & $\begin{array}{l}\text { Add Health } \\
\text { study (EUA) }\end{array}$ & $\begin{array}{c}11-19 \\
\text { anos até } \\
12-20 \\
\text { anos }\end{array}$ & 9602 & $\begin{array}{l}\text { Violência em } \\
\text { relacionamento } \\
\text { homossexual }\end{array}$ & $\begin{array}{c}\text { Delinquência violenta } \\
\text { (autoinforme por } \\
\text { questionário) }\end{array}$ \\
\hline $\begin{array}{l}\text { Leach et } \\
\text { al., } 2016\end{array}$ & $\begin{array}{l}\text { Queensland } \\
\text { Longitudinal } \\
\text { Data } \\
\text { (Austrália) }\end{array}$ & $\mathrm{n} / \mathrm{a}$ & 1882 & $\begin{array}{l}\text { Abuso físico (autoinforme } \\
\text { por questionário) }\end{array}$ & $\begin{array}{c}\text { Delito sexual } \\
\text { (Australian Bureau of } \\
\text { Statistics, 2011) }\end{array}$ \\
\hline
\end{tabular}




\begin{tabular}{|c|c|c|c|c|c|}
\hline $\begin{array}{l}\text { Leach et } \\
\text { al., } 2016\end{array}$ & $\begin{array}{c}\text { Queensland } \\
\text { Longitudinal } \\
\text { Data } \\
\text { (Austrália) }\end{array}$ & $\mathrm{n} / \mathrm{a}$ & 1882 & $\begin{array}{l}\text { Abuso emocional } \\
\text { (autoinforme por } \\
\text { questionário) }\end{array}$ & $\begin{array}{c}\text { Delito sexual } \\
\text { (Australian Bureau of } \\
\text { Statistics, 2011) }\end{array}$ \\
\hline $\begin{array}{l}\text { Leach et } \\
\text { al., } 2016\end{array}$ & $\begin{array}{c}\text { Queensland } \\
\text { Longitudinal } \\
\text { Data } \\
\text { (Austrália) }\end{array}$ & $\mathrm{n} / \mathrm{a}$ & 1882 & $\begin{array}{l}\text { Abuso sexual (autoinforme } \\
\text { por questionário) }\end{array}$ & $\begin{array}{c}\text { Delito sexual } \\
\text { (Australian Bureau of } \\
\text { Statistics, 2011) }\end{array}$ \\
\hline $\begin{array}{l}\text { Farrell \& } \\
\text { Zimmerm } \\
\text { an, } 2018\end{array}$ & $\begin{array}{l}\text { Add Health } \\
\text { study (EUA) }\end{array}$ & $\begin{array}{l}18-30 \\
\text { anos }\end{array}$ & 7706 & $\begin{array}{l}\text { Exposição a violência } \\
\text { (autoinforme por } \\
\text { questionário) }\end{array}$ & $\begin{array}{c}\text { Delinquência violenta } \\
\text { (autoinforme por } \\
\text { questionário) }\end{array}$ \\
\hline $\begin{array}{l}\text { Farrell \& } \\
\text { Zimmerm } \\
\text { an, } 2017\end{array}$ & $\begin{array}{l}\text { Add Health } \\
\text { study (EUA) }\end{array}$ & $\begin{array}{l}12-18 \\
\text { anos }\end{array}$ & 12603 & $\begin{array}{c}\text { Exposição a violência } \\
\text { (geral; autoinforme por } \\
\text { questionário) }\end{array}$ & $\begin{array}{c}\text { Delinquência violenta } \\
\text { (autoinforme por } \\
\text { questionário) }\end{array}$ \\
\hline
\end{tabular}

VI = Variável independente; $\mathrm{VD}$ = variável dependente

O.R. [IC 95\%]

\begin{tabular}{|c|c|c|}
\hline & & \\
\hline & & $1.03[0.99,1.07]$ \\
\hline & 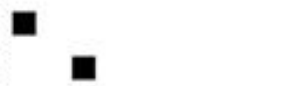 & $3.10[2.92,3.27]$ \\
\hline $\begin{array}{l}\text { Espelage et al. } 2018 \\
\text { Niño et al. } 2017 \\
\text { McCuddy \& Esbense }\end{array}$ & - & $5.21[4.87,5.54]$ \\
\hline McCuddy \& Esbensen, 2017 & E & $2.64[2.21,3.07]$ \\
\hline Gehring \& Vaske, 2017 & 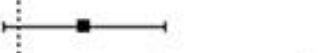 & $2.34[-0.50,5.18]$ \\
\hline \multirow{2}{*}{$\begin{array}{l}\text { Gehring \& Vaske, } 2017 \\
\text { Leach et al., } 2016\end{array}$} & & $4.94[-0.03,9.91]$ \\
\hline & घ & $1.17[1.04,1.31]$ \\
\hline Leach et al., 2016 & घ & $1.12[1.00,1.23]$ \\
\hline Leach et al., 2016 & - & $1.49[1.14,1.84]$ \\
\hline Zimmerman, 2018 & = & $1.91[1.30,2.52]$ \\
\hline Farrell \& Zimmerman, 2017 & $\mathbf{D}$ & $3.56[3.15,3.97]$ \\
\hline \multirow[t]{3}{*}{ RE Model } & - & $2.41[1.55,3.27]$ \\
\hline & 11 & \\
\hline & $\begin{array}{llllll}0 & 2 & 4 & 6 & 8 & 10\end{array}$ & \\
\hline
\end{tabular}

Figura 2.1. Forest plot da razão de chances de se envolver em comportamento violento dado à exposição à violência. $\mathrm{Q}=1250 ; \mathrm{df}=11(\mathrm{p}<0,001) ; \mathrm{I}^{2}=99,5 ; \mathrm{Z}=5,5(\mathrm{p}<0,001)$. (Fonte: autor)

Um segundo aspecto da exposição à violência identificado nos estudos revisados foi o efeito cumulativo da exposição. A exposição crônica à violência pode superativar sistemas hormonais e neuroquímicos relacionados ao estresse, podendo resultar em desajustes fisiológicos e em danos físicos e mentais (Olofsson, Lindqvist, Shaw, \& Danielsson, 2012). A Tabela 2.2 apresenta as características dos seis estudos que avaliaram o efeito cumulativo da exposição à violência, e a Figura 2.2 mostra que a exposição a mais de um tipo de violência ou a exposição por um período prolongado de violência aumentam as chances de comportamento violento em período subsequente, a depender do tipo de exposição (VI). 
Tabela 2.2

Características dos estudos sobre o efeito cumulativo de experiências adversas

\begin{tabular}{|c|c|c|c|c|c|}
\hline Autores & Estudo (País) & Idade & $\mathbf{n}$ & V.I. & V.D. \\
\hline $\begin{array}{l}\text { Fagan \& } \\
\text { Novak, } \\
2018\end{array}$ & $\begin{array}{l}\text { LONGSCAN } \\
\text { Study (EUA) }\end{array}$ & 4-16 anos & 184 & $\begin{array}{l}\text { Total de experiências } \\
\text { adversas na infância }\end{array}$ & $\begin{array}{l}\text { Delinquência violenta } \\
\text { (autoinforme por } \\
\text { questionário) }\end{array}$ \\
\hline $\begin{array}{l}\text { Fagan \& } \\
\text { Novak, } \\
2018\end{array}$ & $\begin{array}{l}\text { LONGSCAN } \\
\text { Study (EUA) }\end{array}$ & 4-16 anos & 320 & $\begin{array}{l}\text { Total de experiências } \\
\text { adversas na infância }\end{array}$ & $\begin{array}{l}\text { Delinquência violenta } \\
\text { (autoinforme por } \\
\text { questionário) }\end{array}$ \\
\hline $\begin{array}{l}\text { Farrell \& } \\
\text { Zimmerman } \\
\text {, } 2017\end{array}$ & $\begin{array}{l}\text { Add Health study } \\
\text { (EUA) }\end{array}$ & $\begin{array}{l}12-18 \\
\text { anos }\end{array}$ & $\begin{array}{c}1260 \\
3\end{array}$ & $\begin{array}{l}\text { Dois ou mais incidentes } \\
\text { de um só tipo }\end{array}$ & $\begin{array}{l}\text { Delinquência violenta } \\
\text { (autoinforme por } \\
\text { questionário) }\end{array}$ \\
\hline $\begin{array}{l}\text { Farrell \& } \\
\text { Zimmerman } \\
\text {, } 2017\end{array}$ & $\begin{array}{l}\text { Add Health study } \\
\text { (EUA) }\end{array}$ & $\begin{array}{l}12-18 \\
\text { anos }\end{array}$ & $\begin{array}{c}1260 \\
3\end{array}$ & $\begin{array}{l}\text { Dois ou mais incidentes } \\
\text { de dois ou mais tipos } \\
\text { (Polivitimização) }\end{array}$ & $\begin{array}{l}\text { Delinquência violenta } \\
\text { (autoinforme por } \\
\text { questionário) }\end{array}$ \\
\hline $\begin{array}{l}\text { Leach et al., } \\
2016\end{array}$ & $\begin{array}{l}\text { Queensland } \\
\text { Longitudinal } \\
\text { Data (Austrália) }\end{array}$ & $\mathrm{n} / \mathrm{a}$ & 1882 & $\begin{array}{l}\text { Vitimização por mais de } \\
12 \text { anos (autoinforme } \\
\text { por questionário) }\end{array}$ & $\begin{array}{l}\text { Delito sexual } \\
\text { (Australian Bureau of } \\
\text { Statistics, 2011) }\end{array}$ \\
\hline $\begin{array}{l}\text { Leach et al., } \\
2016\end{array}$ & $\begin{array}{l}\text { Queensland } \\
\text { Longitudinal } \\
\text { Data (Austrália) }\end{array}$ & $\mathrm{n} / \mathrm{a}$ & 1882 & Polivitimização & $\begin{array}{l}\text { Delito sexual } \\
\text { (Australian Bureau of } \\
\text { Statistics, 2011) }\end{array}$ \\
\hline
\end{tabular}

$\mathrm{VI}$ = variável independente; $\mathrm{VD}=$ variável dependente

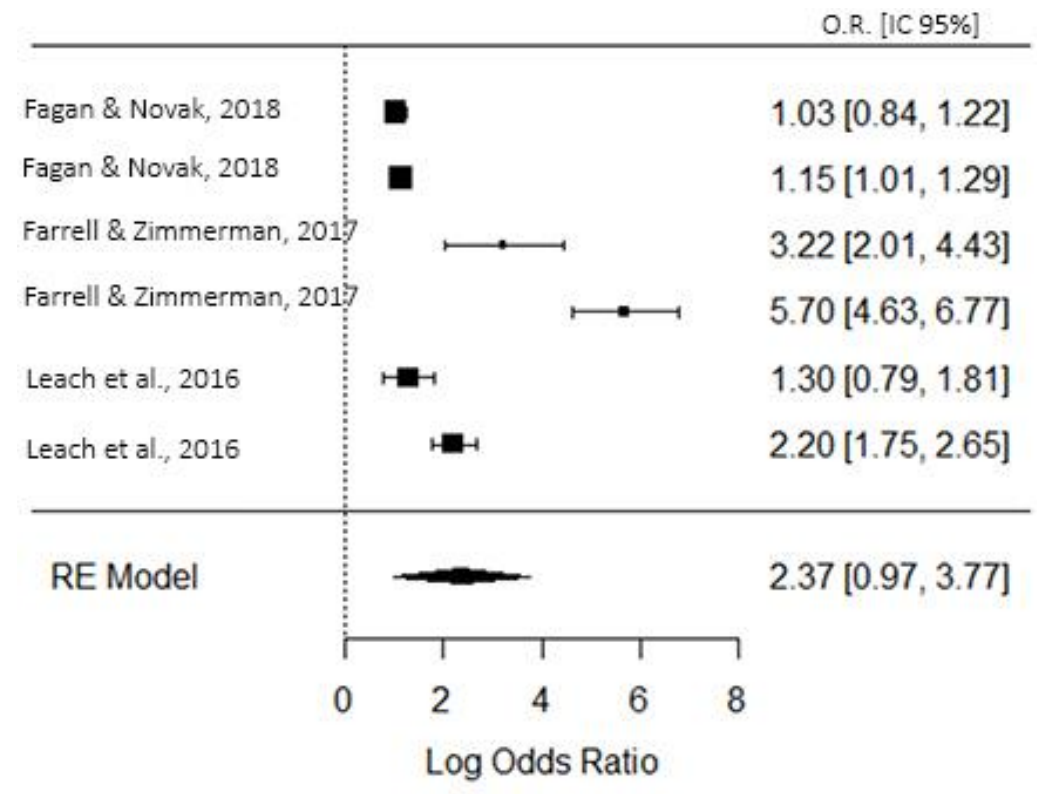

Figura 2.2. Forest plot da razão de chances de se envolver em comportamento violento dado à exposição cumulativa à violência. $\mathrm{Q}=99,8 ; \mathrm{df}=6(\mathrm{p}<0,001) ; \mathrm{I}^{2}=99,0 ; \mathrm{Z}=3,31(\mathrm{p}<$ 0,001). (Fonte: autor).

A segunda subcategoria remete ao histórico de problemas de comportamentos. A Tabela 2.3 mostra que os problemas de comportamento identificados variam entre expulsão e 
evasão escolar, comportamentos antissociais, delitos de forma geral ou os sexuais em particular, anteriores. Outros estudos, anteriores ao período abarcado pela presente revisão, estipulam que histórico de condutas violentas é o melhor preditor da conduta violenta futura, especialmente nos casos em que ocorrem de forma precoce ou com elevada frequência (Borum, Bartel \& Forth, 2006; White, Moffitt, Earls, Robins \& Silva, 1990). Para fins de avaliação, os protocolos de risco consideram que os atos violentos devem ser suficientemente graves para que tenham motivado ou que possam motivar a abertura de um processo judicial, de modo que se excluem desses atos agressões menores que aparentemente não ofereçam grandes riscos à vítima (Andrés-Pueyo, Arbach-Lucioni \& Redondo-Illescas, 2009; Borum, Bartel \& Forth, 2006; Webster, Douglas, Eaves \& Hart, 1997). Esses estudos indicam que o efeito dessas variáveis na composição do risco de violência é maior no período proximal ao episódio de violência e vai diminuindo com o passar do tempo (Borum, Bartel \& Forth, 2006). Por esse motivo, pode-se conjecturar que o efeito identificado pela presente análise e apresentado na Figura 2.3 seja maior, uma vez que a maioria dos estudos analisados incluem comportamentos antissociais em geral, o que pode diluir o efeito que seria obtido apenas se fossem considerados os delitos violentos.

Tabela 2.3

Características dos estudos sobre histórico de problemas de comportamento

\begin{tabular}{|c|c|c|c|c|c|}
\hline Autores & Estudo (País) & Idade & $\mathbf{n}$ & V.I. & V.D. \\
\hline $\begin{array}{l}\text { Sampson } \\
\text { \& Winter, } \\
2018\end{array}$ & $\begin{array}{l}\text { Project on Human } \\
\text { Development in } \\
\text { Chicago (EUA) }\end{array}$ & $\mathrm{n} / \mathrm{a}$ & 212 & $\begin{array}{l}\text { Comportamento antissocial } \\
\text { (coletado entre } 16 \text { e } 18 \text { anos; } \\
\text { Child Behavior Checklist; } \\
\text { CBCL) }\end{array}$ & $\begin{array}{l}\text { Delinquência } \\
\text { violenta (registros } \\
\text { oficiais) }\end{array}$ \\
\hline $\begin{array}{l}\text { Stander et } \\
\text { al., } 2018\end{array}$ & $\begin{array}{l}\text { The Survey of } \\
\text { Recruits' Behaviors } \\
\text { (EUA) }\end{array}$ & $\begin{array}{l}18-20 \\
\text { anos }\end{array}$ & 547 & $\begin{array}{l}\text { Assédio Sexual (Sexual } \\
\text { Experiences Questionnaire } \\
\text { (SEQ)- DoD version } \\
\text { (Fitzgerald, Magley, Drasgow, \& } \\
\text { Waldo, 1999) }\end{array}$ & $\begin{array}{l}\text { Agressão Sexual } \\
\text { (The Sexual } \\
\text { Experiences Survey } \\
\text { (SES; } \\
\text { Koss \& Gidycz, } \\
\text { 1985; Koss \& Oros, } \\
1982 \text { ) }\end{array}$ \\
\hline $\begin{array}{l}\text { Stander et } \\
\text { al., } 2018\end{array}$ & $\begin{array}{l}\text { The Survey of } \\
\text { Recruits' Behaviors } \\
\text { (EUA) }\end{array}$ & $\begin{array}{l}18-20 \\
\text { anos }\end{array}$ & 552 & $\begin{array}{l}\text { Assédio Sexual Coercitivo } \\
\text { (Sexual Experiences } \\
\text { Questionnaire; Fitzgerald et al., } \\
\text { 1999) }\end{array}$ & $\begin{array}{l}\text { Estupro (The Sexual } \\
\text { Experiences Survey } \\
\text { (SES; } \\
\text { Koss \& Gidycz, } \\
\text { 1985; Koss \& Oros, } \\
\text { 1982) }\end{array}$ \\
\hline $\begin{array}{l}\text { Goodnight } \\
\text { et al., } \\
2017\end{array}$ & $\begin{array}{l}\text { Child Development } \\
\text { Project (CDP) }\end{array}$ & $\begin{array}{l}6-23 \\
\text { anos }\end{array}$ & 466 & $\begin{array}{l}\text { Comportamento antissocial } \\
\text { (Youth Self-Report Form; } \\
\text { Achenbach, 1991) }\end{array}$ & $\begin{array}{l}\text { Agressão ao parceiro } \\
\text { íntimo (Revised } \\
\text { Conflict Tactics } \\
\text { Scale; Straus et al., } \\
\text { 1996) }\end{array}$ \\
\hline Goodnight & Child Development & $12-23$ & 466 & Comportamento antissocial & Agressão ao parceiro \\
\hline
\end{tabular}




\begin{tabular}{|c|c|c|c|c|c|}
\hline $\begin{array}{l}\text { et al., } \\
2017\end{array}$ & Project (CDP) & anos & & $\begin{array}{l}\text { (Youth Self-Report Form; } \\
\text { Achenbach, 1991) }\end{array}$ & $\begin{array}{l}\text { íntimo (Revised } \\
\text { Conflict Tactics } \\
\text { Scale; Straus et al., } \\
\text { 1996) }\end{array}$ \\
\hline $\begin{array}{l}\text { Longmore } \\
\text { et al., } \\
2016\end{array}$ & $\begin{array}{l}\text { The Toledo Adolescent } \\
\text { Relationships Study } \\
\text { (EUA) }\end{array}$ & $\begin{array}{l}12-23 \\
\text { anos }\end{array}$ & 294 & $\begin{array}{l}\text { Número de parceiros sexuais } \\
\text { fixos durante a adolescência } \\
\text { (autoinforme por questionário) }\end{array}$ & $\begin{array}{l}\text { Agressão ao parceiro } \\
\text { íntimo (Revised } \\
\text { Conflict Tactics } \\
\text { Scale; Straus et al., } \\
\text { 1996) }\end{array}$ \\
\hline $\begin{array}{l}\text { Theobald } \\
\text { et al., } \\
2016\end{array}$ & $\begin{array}{l}\text { Cambridge Study in } \\
\text { Delinquent } \\
\text { Development (Reino } \\
\text { Unido) }\end{array}$ & $\begin{array}{l}8-32 \\
\text { anos }\end{array}$ & 152 & $\begin{array}{l}\text { Suspensão escolar (autoinforme } \\
\text { por questionário) }\end{array}$ & $\begin{array}{l}\text { Agressão ao parceiro } \\
\text { íntimo (Revised } \\
\text { Conflict Tactics } \\
\text { Scale; Straus et al., } \\
\text { 1996) }\end{array}$ \\
\hline $\begin{array}{l}\text { Theobald } \\
\text { et al., } \\
2016\end{array}$ & $\begin{array}{l}\text { Cambridge Study in } \\
\text { Delinquent } \\
\text { Development (Reino } \\
\text { Unido) }\end{array}$ & $\begin{array}{l}8-32 \\
\text { anos }\end{array}$ & 152 & $\begin{array}{l}\text { Evasão escolar (autoinforme por } \\
\text { questionário) }\end{array}$ & $\begin{array}{l}\text { Agressão ao parceiro } \\
\text { íntimo (Revised } \\
\text { Conflict Tactics } \\
\text { Scale; Straus et al., } \\
\text { 1996) }\end{array}$ \\
\hline $\begin{array}{l}\text { Theobald } \\
\text { et al., } \\
2016\end{array}$ & $\begin{array}{l}\text { Cambridge Study in } \\
\text { Delinquent } \\
\text { Development (Reino } \\
\text { Unido) }\end{array}$ & $\begin{array}{l}8-32 \\
\text { anos }\end{array}$ & 152 & $\begin{array}{l}\text { Delito oficial (autoinforme por } \\
\text { questionário) }\end{array}$ & $\begin{array}{l}\text { Agressão ao parceiro } \\
\text { intimo (Revised } \\
\text { Conflict Tactics } \\
\text { Scale; Straus et al., } \\
\text { 1996) }\end{array}$ \\
\hline
\end{tabular}

VI = variável independente; $\mathrm{VD}=$ Variável dependente

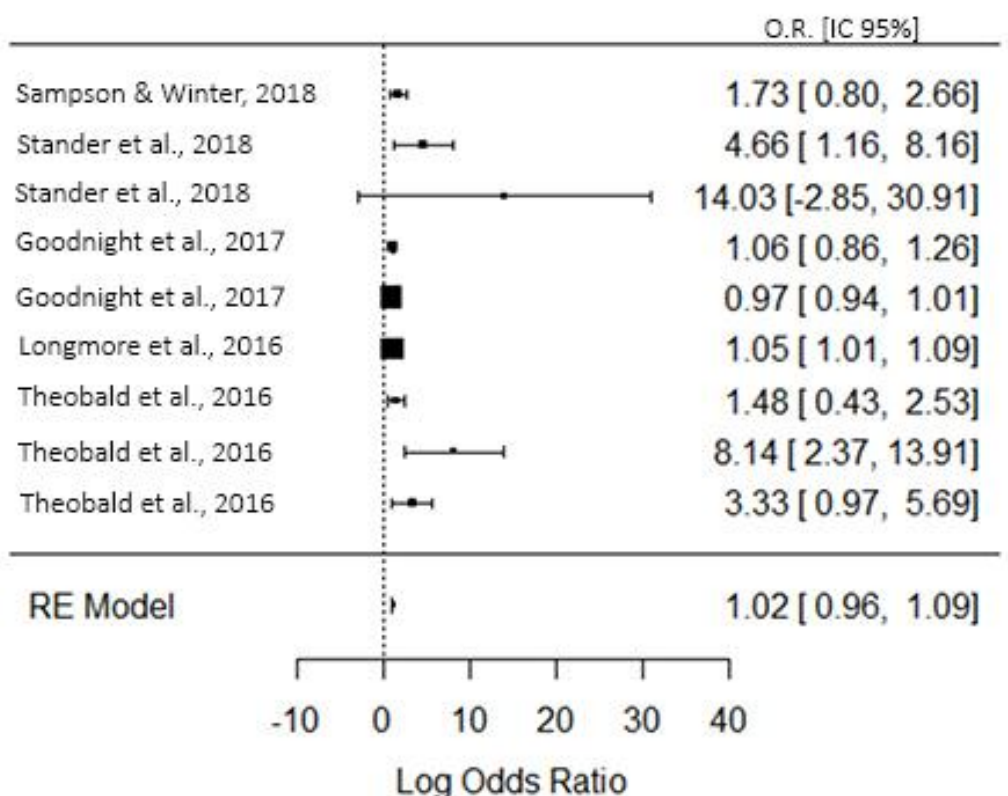

Figura 2.3. Forest plot da razão de chances de se envolver em comportamento violento dado o histórico de problemas de comportamentos. $Q=27,6 ; \mathrm{df}=9(\mathrm{p}=0,001) ; \mathrm{I}^{2}=46,7 ; \mathrm{Z}=29,8$ $(\mathrm{p}<0,001)$. (Fonte: autor). 
A última subcategoria de fatores históricos refere-se ao fracasso em cumprir satisfatoriamente programas de tratamentos anteriores, no contexto dos serviços de justiça juvenil ou de saúde mental (Andrés-Pueyo, Arbach-Lucioni \& Redondo-Illescas, 2009; Borum, Bartel \& Forth, 2006). Alguns exemplos de fatores nesse domínio seriam abandono ou a resistência em seguir um tratamento - faltar muitas vezes, chegar atrasado, não cumprir o combinado ou não colaborar com as atividades. Essa variável não foi identificada no levantamento por ser verificável em amostras clínicas que, por razão de controle, foram excluídas dos critérios de inclusão. Todavia, esse fator está presente na maioria dos protocolos de ARV devido à evidência empírica de que a falha em seguir com tratamentos indicados aumenta o risco de violência; por isso sua menção no presente tópico (Sartin, Hansen \& Huss, 2006; Swartz, Bhattacharya, Robertson \& Swanson, 2016).

Passando para a categoria de Fatores Pessoais, cinco variáveis relativas a características de funcionamento psicológico foram identificadas: baixo autocontrole, emotividade negativa, traços de psicopatia e transtornos de saúde mental.

O autocontrole consiste em um dos núcleos básicos das funções executivas e envolve a capacidade de exercer controle sobre as próprias emoções e condutas, resistindo a vontades ou a prazeres imediatos em função de metas de longo prazo, mais significativas, e/ou em função da previsão de consequências negativas dos comportamentos (Delise, 2014; Diamond, 2013; Komatsu, Costa \& Bazon, 2018). A relação entre autocontrole e engajamento infracional possui tantas evidências empíricas que o conceito de autocontrole ocupa um papel de destaque em muitas das teorias criminológicas (Gottfredson \& Hirschi, 1990; Le Blanc, 2009; Moffitt, 1993; Wikström, 2005). Na vida cotidiana, há muitas situações capazes de alterar o estado emocional das pessoas e incitar condutas violentas que só podem ser inibidas com o uso adequado de habilidades de autorregulação comportamental. Indivíduos com dificuldades de exercer o autocontrole tendem a agir de forma impulsiva mais frequentemente, utilizando-se dos mais variados recursos para atenderem suas vontades ou necessidades, de forma mais imediata, entre eles o uso da violência (Gottfredson, 2018). A Figura 2.4 mostra que os estudos levantados abordaram os três domínios do autocontrole descrito por Gottfredson e Hirschi (1990): temperamento, busca por risco e impulsividade. Os resultados mostram que a exposição aos indicadores de baixo autocontrole aumenta significativamente as chances de envolvimento em atos violentos. 
Tabela 2.4

Características dos estudos sobre autocontrole

\begin{tabular}{|c|c|c|c|c|c|}
\hline Autores & Estudo (País) & Idade & $\mathrm{n}$ & V.I. & V.D. \\
\hline $\begin{array}{l}\text { Espelage } \\
\text { et al., } \\
2018\end{array}$ & EUA & $\begin{array}{l}10- \\
16 \\
\text { anos }\end{array}$ & 1655 & $\begin{array}{l}\text { Impulsividade (Teen } \\
\text { Conflict Survey, } \\
\text { Bosworth et al. 1999) }\end{array}$ & $\begin{array}{l}\text { Agressão Relacional (tentativa de } \\
\text { causar dano a reputação da outra } \\
\text { criança/jovem (Relational } \\
\text { Aggression Scale; Crick, 1996) }\end{array}$ \\
\hline $\begin{array}{l}\text { Vogel \& } \\
\text { Van Ham, } \\
2018\end{array}$ & $\begin{array}{l}\text { Add Health study } \\
\text { (EUA) }\end{array}$ & $\begin{array}{l}12- \\
18 \\
\text { anos }\end{array}$ & 12935 & $\begin{array}{l}\text { Impulsividade } \\
\text { (autoinforme por } \\
\text { questionário) }\end{array}$ & $\begin{array}{l}\text { Delinquência violenta (autoinforme } \\
\text { por questionário) }\end{array}$ \\
\hline $\begin{array}{l}\text { Vogel \& } \\
\text { Van Ham, } \\
2018\end{array}$ & $\begin{array}{l}\text { Add Health study } \\
\text { (EUA) }\end{array}$ & $\begin{array}{l}12- \\
18 \\
\text { anos }\end{array}$ & 12935 & $\begin{array}{l}\text { Impulsividade (em } \\
\text { vizinhanças } \\
\text { desfavorecidas; } \\
\text { (autoinforme por } \\
\text { questionário) }\end{array}$ & $\begin{array}{l}\text { Delinquência violenta (autoinforme } \\
\text { por questionário) }\end{array}$ \\
\hline $\begin{array}{l}\text { Vogel \& } \\
\text { Van Ham, } \\
2018\end{array}$ & $\begin{array}{l}\text { Add Health study } \\
\text { (EUA) }\end{array}$ & $\begin{array}{l}12- \\
18 \\
\text { anos }\end{array}$ & 12936 & $\begin{array}{l}\text { Impulsividade (em } \\
\text { vizinhanças não } \\
\text { desfavorecidas); } \\
\text { (autoinforme por } \\
\text { questionário) }\end{array}$ & $\begin{array}{l}\text { Delinquência violenta (autoinforme } \\
\text { por questionário) }\end{array}$ \\
\hline $\begin{array}{l}\text { Goodnight } \\
\text { et al., } \\
2017\end{array}$ & $\begin{array}{l}\text { Child } \\
\text { Development } \\
\text { Project (CDP) }\end{array}$ & $\begin{array}{l}5-23 \\
\text { anos }\end{array}$ & 466 & $\begin{array}{l}\text { Resistência para } \\
\text { autocontrole } \\
\text { (Retrospective Infant } \\
\text { Characteristics } \\
\text { Questionnaire; Bates et } \\
\text { al., 1998) }\end{array}$ & $\begin{array}{l}\text { Agressão ao parceiro íntimo } \\
\text { (Revised Conflict Tactics Scale; } \\
\text { Straus et al., 1996) }\end{array}$ \\
\hline & & & & $\begin{array}{l}\text { Resistência para } \\
\text { autocontrole } \\
\text { (Retrospective Infant }\end{array}$ & \\
\hline $\begin{array}{l}\text { Goodnight } \\
\text { et al., } \\
2017\end{array}$ & $\begin{array}{l}\text { Child } \\
\text { Development } \\
\text { Project (CDP) }\end{array}$ & $\begin{array}{l}11- \\
23 \\
\text { anos }\end{array}$ & 466 & $\begin{array}{l}\text { Characteristics } \\
\text { Questionnaire; Bates et } \\
\text { al., 1998) }\end{array}$ & $\begin{array}{l}\text { Agressão ao parceiro íntimo } \\
\text { (Revised Conflict Tactics Scale; } \\
\text { Straus et al., 1996) }\end{array}$ \\
\hline $\begin{array}{l}\text { Cho et al., } \\
2017\end{array}$ & $\begin{array}{l}\text { Korean Youth } \\
\text { Panel Study (South } \\
\text { Korea) }\end{array}$ & $\begin{array}{l}11- \\
15 \\
\text { anos }\end{array}$ & 2844 & $\begin{array}{l}\text { Baixo autocontrole } \\
\text { (autoinforme por } \\
\text { questionário) }\end{array}$ & $\begin{array}{l}\text { Bullying (autoinforme por } \\
\text { questionário) }\end{array}$ \\
\hline $\begin{array}{l}\text { Jolliffe et } \\
\text { al., } 2016\end{array}$ & $\begin{array}{l}\text { Pittsburgh Youth } \\
\text { Study }\end{array}$ & $\begin{array}{l}10- \\
19 \\
\text { anos }\end{array}$ & 503 & $\begin{array}{l}\text { Hiperatividade alta } \\
\text { (autoinforme por } \\
\text { questionário) }\end{array}$ & $\begin{array}{l}\text { Delinquência Violenta (registro } \\
\text { oficial e autoinforme por } \\
\text { questionário) }\end{array}$ \\
\hline $\begin{array}{l}\text { Theobald } \\
\text { et al., } \\
2016\end{array}$ & $\begin{array}{l}\text { Cambridge Study } \\
\text { in Delinquent } \\
\text { Development } \\
\text { (CSDD; Reino } \\
\text { Unido) }\end{array}$ & $\begin{array}{l}8-32 \\
\text { anos }\end{array}$ & 152 & $\begin{array}{l}\text { Risk taking (autoinforme } \\
\text { por questionário) }\end{array}$ & $\begin{array}{l}\text { Agressão ao parceiro íntimo } \\
\text { (Revised Conflict Tactics Scale; } \\
\text { Straus et al., 1996) }\end{array}$ \\
\hline & $\begin{array}{l}\text { Cambridge Study } \\
\text { in Delinquent }\end{array}$ & & & & \\
\hline $\begin{array}{l}\text { Theobald } \\
\text { et al., } \\
2016\end{array}$ & $\begin{array}{l}\text { Development } \\
\text { (CSDD; Reino } \\
\text { Unido) }\end{array}$ & $\begin{array}{l}8-32 \\
\text { anos }\end{array}$ & & $\begin{array}{l}\text { Dificuldade de atenção } \\
\text { (autoinforme por } \\
\text { questionário) }\end{array}$ & $\begin{array}{l}\text { Agressão ao parceiro íntimo } \\
\text { (Revised Conflict Tactics Scale; } \\
\text { Straus et al., 1996) }\end{array}$ \\
\hline
\end{tabular}

$\mathrm{VI}=$ variável independente; $\mathrm{VD}=$ Variável dependente 
O.R. [IC 95\%]

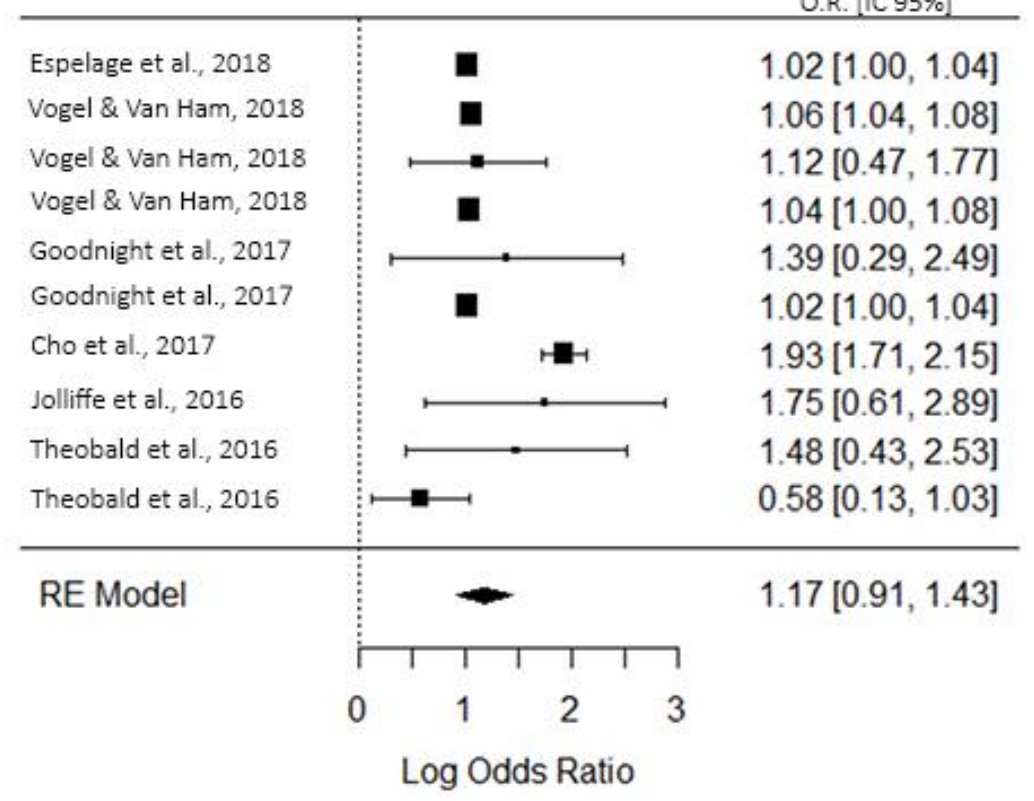

Figura 2.4. Forest plot da razão de chances de se envolver em comportamento violento dado o baixo autocontrole. $\mathrm{Q}=84,0 ; \mathrm{df}=10(\mathrm{p}<0,001) ; \mathrm{I}^{2}=99,7 ; \mathrm{Z}=8,82(\mathrm{p}<0,001)$. (Fonte: autor).

A emotividade negativa remete à tendência em sentir emoções negativas como ansiedade, insegurança, inferioridade, medo ou um mal-estar emocional geral frente a situações corriqueiras, normais. O conceito remete ao conteúdo típico ao traço de personalidade neuroticismo (Eysenck, 1967). Indivíduos com alta emotividade negativa costumam apresentar baixa tolerância à raiva, ao tédio e à frustração, o que os leva a comportarem-se de forma mais reativa e os torna mais vulneráveis aos estímulos externos (Lahey \& Waldman, 2005; Larsen \& Buss, 2014). Os estudos mostram que esses indivíduos podem passar à conduta agressiva sem necessariamente possuírem atitudes antissociais, isso porque as emoções negativas exerceriam a função de provocar o comportamento agressivo (de Barlett \& Anderson, 2012; Dam, Hjordt, Da Cunha-Bang, Sestoft, Knudsen \& Stenbæk, 2018). Nesse sentido, o sentimento de culpa após o ato violento seria uma consequência nesses indivíduos, alimentando um círculo vicioso, ao incrementar a tendência a experimentar emoções negativas. Como apresentado na Tabela 2.5, os estudos identificados no presente levantamento trabalharam com as emoções de raiva, ciúme e medo do abandono, e a Figura 2.5 indica que indivíduos que comumente experimentam esses sentimentos estão sob maior risco. Destaca-se, também, que nesse caso a conduta violenta direciona-se preferencialmente a pessoas conhecidas, como parceiro íntimo. 
Tabela 2.5.

Características dos estudos sobre emotividade negativa

\begin{tabular}{|c|c|c|c|c|c|}
\hline Autores & $\begin{array}{l}\text { Estudo } \\
\text { (País) }\end{array}$ & Idade & $\mathbf{n}$ & V.I. & V.D. \\
\hline $\begin{array}{l}\text { Espelage } \\
\text { et al., } 2018\end{array}$ & EUA & $\begin{array}{l}10-16 \\
\text { anos }\end{array}$ & 1655 & $\begin{array}{l}\text { Raiva (Modified } \\
\text { Agression Scale, } \\
\text { Bosworth et al. 1999) }\end{array}$ & $\begin{array}{l}\text { Agressão Relacional (tentativa de } \\
\text { causar dano a reputação da outra } \\
\text { criança/jovem (Relational } \\
\text { Aggression Scale; Crick, 1996) }\end{array}$ \\
\hline & & & & $\begin{array}{l}\text { Ciúme (Interpersonal } \\
\text { Jealousy Scale; Mathes }\end{array}$ & \\
\hline & $\begin{array}{l}\text { Child } \\
\text { Development }\end{array}$ & & & $\begin{array}{l}\text { \& Severa, 1981) e medo } \\
\text { do abandono }\end{array}$ & Agressão ao parceirc \\
\hline $\begin{array}{l}\text { Goodnight } \\
\text { et al., } 2017\end{array}$ & $\begin{array}{l}\text { Project } \\
\text { (EUA) }\end{array}$ & $\begin{array}{l}8-23 \\
\text { anos }\end{array}$ & 466 & $\begin{array}{l}\text { (Holtzworth-Munroe et } \\
\text { al., 2000) }\end{array}$ & $\begin{array}{l}\text { (Revised Conflict Tactics Scale; } \\
\text { Straus et al., 1996) }\end{array}$ \\
\hline $\begin{array}{l}\text { Goodnight } \\
\text { et al } \\
\text { (2017) }\end{array}$ & $\begin{array}{l}\text { Child } \\
\text { Development } \\
\text { Project } \\
\text { (EUA) }\end{array}$ & $\begin{array}{l}14-23 \\
\text { anos }\end{array}$ & 466 & $\begin{array}{l}\text { Ciúme (Interpersonal } \\
\text { Jealousy Scale; } \\
\text { Mathes \& Severa, 1981) } \\
\text { e medo do abandono } \\
\text { (Holtzworth-Munroe et } \\
\text { al., 2000) }\end{array}$ & $\begin{array}{l}\text { Agressão ao parceiro íntimo } \\
\text { (Revised Conflict Tactics Scale; } \\
\text { Straus et al., 1996) }\end{array}$ \\
\hline
\end{tabular}

VI = variável independente; $\mathrm{VD}=$ Variável dependente

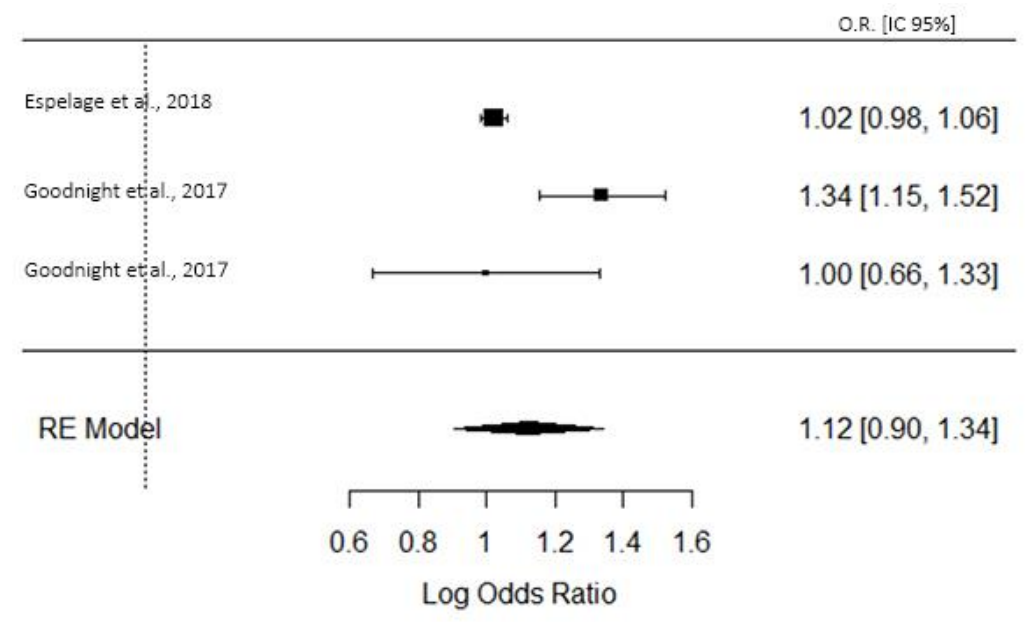

Figura 2.5. Forest plot da razão de chances de se envolver em comportamento violento dada a emotividade negativa. $\mathrm{Q}=10,9 ; \mathrm{df}=3(\mathrm{p}=0,004) ; \mathrm{I}^{2}=80,0 ; \mathrm{Z}=9,98(\mathrm{p}<0,001)$. (Fonte: autor).

Outro fator pessoal que se destaca nas pesquisa são os traços de psicopatia, que incluem componentes que se manifestam nas interações interpessoais (ex: charme superficial), na conduta (ex: atos antissociais frequentes/graves) e no plano das emoções (ex: baixa empatia, frieza/insensibilidade) que têm sido identificados por diferentes estudos como importantes preditores de conduta violenta (Goodnight et al., 2017; Jolliffe, Farrington, Loeber \& Pardini, 2016). Diferentemente da negatividade emocional, cuja motivação 
subjacente é, predominantemente, a hostilidade (frustração ou raiva), os traços de psicopatia consistem em um risco especial para a violência utilitária, na qual as características pessoais especialmente a baixa empatia e a insensibilidade - diminuem ou anulam os efeitos protetores do autoconstrangimento que poderiam inibir a conduta violenta. A Tabela 2.6 descreve os estudos levantados que investigaram traços de psicopatia, e a Figura 2.6 mostra que indivíduos com pontuações de risco nas escalas de traços de psicopatia possuem uma chance de envolvimento em condutas violentas três vezes maior que indivíduos cuja pontuação não está na faixa de risco.

Tabela 2.6

Características dos estudos sobre os traços de psicopatia

\begin{tabular}{|c|c|c|c|c|c|}
\hline Autores & $\begin{array}{l}\text { Estudo } \\
\text { (País) }\end{array}$ & Idade & $\mathbf{n}$ & V.I. & V.D. \\
\hline $\begin{array}{l}\text { Espelage et } \\
\text { al., } 2018\end{array}$ & EUA & $\begin{array}{l}10-16 \\
\text { anos }\end{array}$ & 1655 & $\begin{array}{l}\text { Preocupação Empática } \\
\text { (Teen Conflict Scale; } \\
\text { Bosworth et al. 1999) }\end{array}$ & $\begin{array}{l}\text { Agressão Relacional (tentativa de } \\
\text { causar dano a reputação da outra } \\
\text { criança/jovem (Relational Aggression } \\
\text { Scale (Crick, 1996) }\end{array}$ \\
\hline & $\begin{array}{l}\text { Child } \\
\text { Development }\end{array}$ & & & $\begin{array}{l}\text { Traços Psicopáticos } \\
\text { (Antisocial Process }\end{array}$ & Agressão ao parceiro íntimo (Revised \\
\hline $\begin{array}{l}\text { Goodnight et } \\
\text { al., } 2017\end{array}$ & $\begin{array}{l}\text { Project } \\
\text { (EUA) }\end{array}$ & $\begin{array}{l}7-23 \\
\text { anos }\end{array}$ & 466 & $\begin{array}{l}\text { Screening Device; Frick } \\
\& \text { Hare, 2001) }\end{array}$ & $\begin{array}{l}\text { Conflict Tactics Scale; Straus et al., } \\
\text { 1996) }\end{array}$ \\
\hline $\begin{array}{l}\text { Goodnight et } \\
\text { al., } 2017\end{array}$ & $\begin{array}{l}\text { Child } \\
\text { Development } \\
\text { Project } \\
\text { (EUA) }\end{array}$ & $\begin{array}{l}13-23 \\
\text { anos }\end{array}$ & 466 & $\begin{array}{l}\text { Traços Psicopáticos } \\
\text { (Antisocial Process } \\
\text { Screening Device; Frick } \\
\text { \& Hare, 2001) }\end{array}$ & $\begin{array}{l}\text { Agressão ao parceiro íntimo (Revised } \\
\text { Conflict Tactics Scale; Straus et al., } \\
\text { 1996) }\end{array}$ \\
\hline $\begin{array}{l}\text { Jolliffe et al., } \\
2016\end{array}$ & $\begin{array}{l}\text { Pittsburgh } \\
\text { Youth Study } \\
\text { (EUA) }\end{array}$ & $\begin{array}{l}10-19 \\
\text { anos }\end{array}$ & 503 & $\begin{array}{l}\text { Traços psicopáticos } \\
\text { (Recent Mood and } \\
\text { Feelings Questionnaire; } \\
\text { Costello \& Angold, 1988) }\end{array}$ & $\begin{array}{l}\text { Delinquência Violenta (registro } \\
\text { oficial e autoinforme por } \\
\text { questionário) }\end{array}$ \\
\hline
\end{tabular}

$\mathrm{VI}$ = variável independente; $\mathrm{VD}=$ Variável dependente 


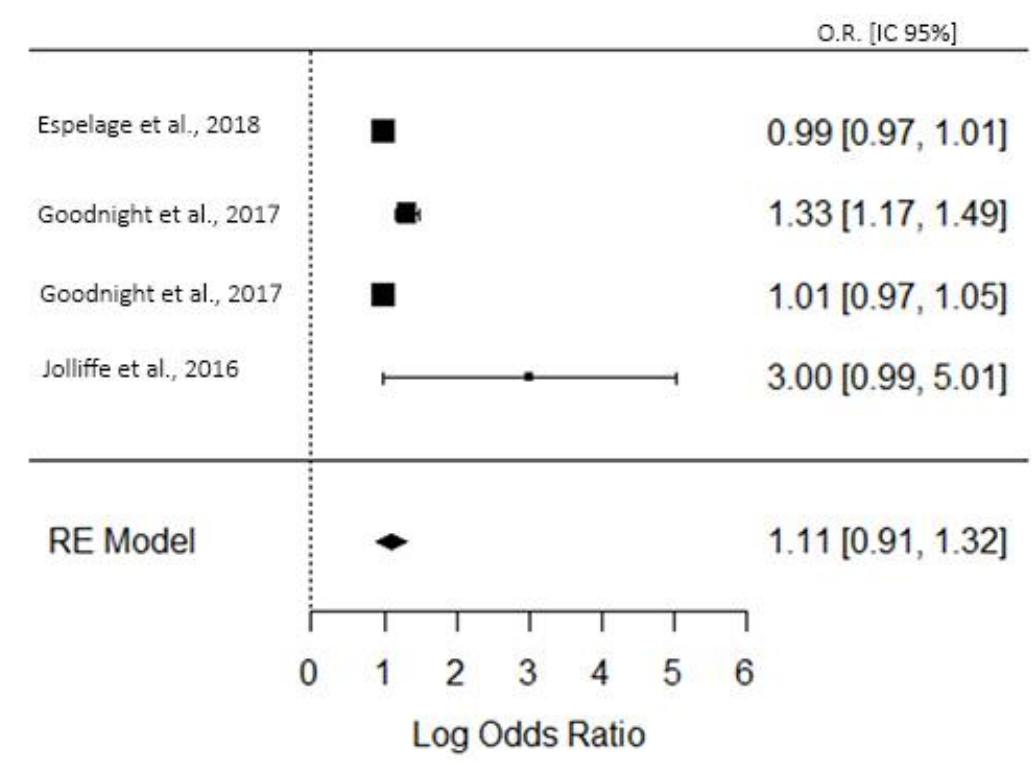

Figura 2.6. Forest plot da razão de chances de se envolver em comportamento violento dado os traços de psicopatia. $\mathrm{Q}=20,6$; $\mathrm{df}=4$ (p<0,001); $\mathrm{I}^{2}=97,8 ; \mathrm{Z}=10,5$ (p < 0,001). (Fonte: autor).

Por fim, os transtornos de saúde mental também se destacam por sua relação com condutas violentas. A revisão de Rueve e Welton (2008) mostra que a taxa de crimes violentos cometidos por amostras da população psiquiátrica equivale virtualmente a de crimes cometidos pela população geral. No entanto, alguns protocolos de ARV destacam diagnósticos de transtornos mentais severos, psicóticos e bipolares, como importante preditores do comportamento violento (Andrés-Pueyo, Arbach-Lucion \& Redondo-Illescas, 2009; Séguin, Booij \& Lilienfeld, 2018; Webster, Douglas, Eaves \& Hart, 1997). De fato, a Tabela 2.7 e a Figura 2.7 mostram que transtornos orgânicos, neuróticos, psicóticos, de abuso de substâncias e de personalidade apresentam razões superiores a de transtornos de ansiedade e de depressão. Andrés-Pueyo, Arbach-Lucion e Redondo-Illescas (2009) apontam que podem ser indicadores de transtorno mental grave a incapacidade em discernir a realidade, delírios e alucinações, pensamento racional deteriorado, isolamento severo, mania, afeto inapropriado e outros sintomas que invalidem a capacidade de autocontrole ou que produzam ideações suicida ou homicida. Nesse domínio se destacam os problemas de abuso de substâncias por serem capazes de produzir os referidos sintomas (Caton, Samet \& Hasin, 2000). Ademais, são condições que retroalimentam as dificuldades psicossociais e geram o desafio de sustentar o vício, aspectos que também concorrem para aumentar o risco de desenvolvimento ou de manutenção de padrões de comportamento infracional (Bono, Komatsu \& Bazon, 2019; Hawkins, Jenson, Catalano \& Lishner, 1988). 
Tabela 2.7

Características dos estudos sobre condições de saúde mental

\begin{tabular}{|c|c|c|c|c|c|}
\hline Autores & $\begin{array}{l}\text { Estudo } \\
\text { (País) }\end{array}$ & Idade & $\mathbf{n}$ & V.I. & V.D. \\
\hline $\begin{array}{l}\text { Espelage } \\
\text { et al., } \\
2018\end{array}$ & EUA & 10-16 anos & 1655 & $\begin{array}{l}\text { Sintomas } \\
\text { Depressivos } \\
\text { (Orpinas Modified } \\
\text { Depression Scale; } \\
\text { Orpinas, 1993) }\end{array}$ & $\begin{array}{l}\text { Agressão Relacional } \\
\text { (tentativa de causar dano a } \\
\text { reputação da outra } \\
\text { criança/jovem (Relational } \\
\text { Aggression Scale (Crick } \\
\text { 1996) }\end{array}$ \\
\hline $\begin{array}{l}\text { Dean et } \\
\text { al., } 2018\end{array}$ & Dinamarca & $\begin{array}{l}\text { Coorte de } 1965 \text { a } \\
1998 \text { acompanhada de } \\
2001 \text { a } 2013\end{array}$ & 1002276 & $\begin{array}{l}\text { Transtornos } \\
\text { orgânicos } \\
\text { (Psychiatric Central } \\
\text { Research Register) }\end{array}$ & $\begin{array}{l}\text { Delinquência violenta } \\
\text { (registros oficiais) }\end{array}$ \\
\hline $\begin{array}{l}\text { Dean et } \\
\text { al., } 2018\end{array}$ & Dinamarca & $\begin{array}{l}\text { Coorte de } 1965 \text { a } \\
1998 \text { acompanhada de } \\
2001 \text { a } 2014\end{array}$ & 1002276 & $\begin{array}{l}\text { Transtornos de uso } \\
\text { de substâncias } \\
\text { (Psychiatric Central } \\
\text { Research Register) }\end{array}$ & $\begin{array}{l}\text { Delinquência violenta } \\
\text { (registros oficiais) }\end{array}$ \\
\hline $\begin{array}{l}\text { Dean et } \\
\text { al., } 2018\end{array}$ & Dinamarca & $\begin{array}{l}\text { Coorte de } 1965 \text { a } \\
1998 \text { acompanhada de } \\
2001 \text { a } 2015\end{array}$ & 1002276 & $\begin{array}{l}\text { Transtornos do } \\
\text { espectro da } \\
\text { esquizofrenia } \\
\text { (Psychiatric Central } \\
\text { Research Register) }\end{array}$ & $\begin{array}{l}\text { Delinquência violenta } \\
\text { (registros oficiais) }\end{array}$ \\
\hline $\begin{array}{l}\text { Dean et } \\
\text { al., } 2018\end{array}$ & Dinamarca & $\begin{array}{l}\text { Coorte de } 1965 \text { a } \\
1998 \text { acompanhada de } \\
2001 \text { a } 2016\end{array}$ & 1002276 & $\begin{array}{l}\text { Transtornos } \\
\text { Neuroticos } \\
\text { (Psychiatric Central } \\
\text { Research Register) }\end{array}$ & $\begin{array}{l}\text { Delinquência violenta } \\
\text { (registros oficiais) }\end{array}$ \\
\hline $\begin{array}{l}\text { Dean et } \\
\text { al., } 2018\end{array}$ & Dinamarca & $\begin{array}{l}\text { Coorte de } 1965 \text { a } \\
1998 \text { acompanhada de } \\
2001 \text { a } 2017\end{array}$ & 1002276 & $\begin{array}{l}\text { Transtornos de } \\
\text { Personalidade } \\
\text { (Psychiatric Central } \\
\text { Research Register) }\end{array}$ & $\begin{array}{l}\text { Delinquência violenta } \\
\text { (registros oficiais) }\end{array}$ \\
\hline $\begin{array}{l}\text { Dean et } \\
\text { al., } 2018\end{array}$ & Dinamarca & $\begin{array}{l}\text { Coorte de } 1965 \text { a } \\
1998 \text { acompanhada de } \\
2001 \text { a } 2019\end{array}$ & 1002276 & $\begin{array}{l}\text { Transtornos do } \\
\text { desenvolvimento } \\
\text { (Psychiatric Central } \\
\text { Research Register) }\end{array}$ & $\begin{array}{l}\text { Delinquência violenta } \\
\text { (registros oficiais) }\end{array}$ \\
\hline $\begin{array}{l}\text { Yu et al., } \\
2018\end{array}$ & RADAR & 13 até os 18 anos & 682 & $\begin{array}{l}\text { Sintomas } \\
\text { Depressivos } \\
\text { (RADS-2; } \\
\text { Reynolds 2002) }\end{array}$ & $\begin{array}{l}\text { Delinquência violenta } \\
\text { (autoinforme por } \\
\text { questionário) }\end{array}$ \\
\hline $\begin{array}{l}\text { Yu et al., } \\
2018\end{array}$ & RADAR & 14 e 18 anos & 682 & $\begin{array}{l}\text { Sintomas } \\
\text { Depressivos } \\
\text { (RADS-2; } \\
\text { Reynolds 2002) }\end{array}$ & $\begin{array}{l}\text { Delinquência violenta } \\
\text { (autoinforme por } \\
\text { questionário) }\end{array}$ \\
\hline $\begin{array}{l}\text { Niño et } \\
\text { al., } 2017\end{array}$ & $\begin{array}{l}\text { Add } \\
\text { Health } \\
\text { study } \\
\text { (EUA) }\end{array}$ & $\begin{array}{l}12-17 \text { anos até } 13 \text { e } 18 \\
\text { anos }\end{array}$ & 10665 & $\begin{array}{l}\text { Sintomas } \\
\text { depressivos (Center } \\
\text { for Epidemiologic } \\
\text { Studies Depression } \\
\text { Scale; CES-D) }\end{array}$ & $\begin{array}{l}\text { Delinquência violenta } \\
\text { (autoinforme por } \\
\text { questionário) }\end{array}$ \\
\hline $\begin{array}{l}\text { Sahlin et } \\
\text { al (2017) }\end{array}$ & Suécia & $\begin{array}{l}\text { Indivíduos nascidos } \\
\text { entre } 1982 \text { e } 1988, \\
\text { acompanhados a } \\
\text { partir dos seus } 15 \\
\text { anos de idade }\end{array}$ & 917388 & $\begin{array}{l}\text { Histórico de } \\
\text { autolesão }\end{array}$ & $\begin{array}{l}\text { Delinquência violenta } \\
\text { (registros oficiais) }\end{array}$ \\
\hline Hemminki & Finlândia & 15-21 anos & 30225 & Uso de & Delinquência violenta \\
\hline
\end{tabular}


et al (2016)

Hemminki

et al (2016) Finlândia 15-21 anos

Hemminki

et al (2016) Finlândia

15-21 anos

Hemminki

et al (2016)

Finlândia

15-21 anos

Pittsburgh

Youth

Jolliffe et Study

al., 2016 (EUA) Pittsburgh Youth

Jolliffe et Study al., 2016 (EUA) antidepressivos (registros oficiais)

prévio

Uso de

antidepressivos Delinquência violenta

30225 prévio

Uso de antidepressivos 6

meses antes da

30225 apreensão

Uso de

antidepressivos 6

meses antes da

reincidente (registro oficial)

Delinquência violenta

(registros oficiais)

Delinquência violenta

30225 apreensão reincidente (registro oficial)

Humor depressivo

(Recent Mood and

Feelings

Questionnaire; Delinquência Violenta

Costello \& Angold, (registro oficial e 1988)

autoinforme por questionário)

Ansiedade

(autoinforme por

Delinquência Violenta

(registro oficial e autoinforme por questionário)

$\mathrm{VI}=$ variável independente $; \mathrm{VD}=$ Variável dependente

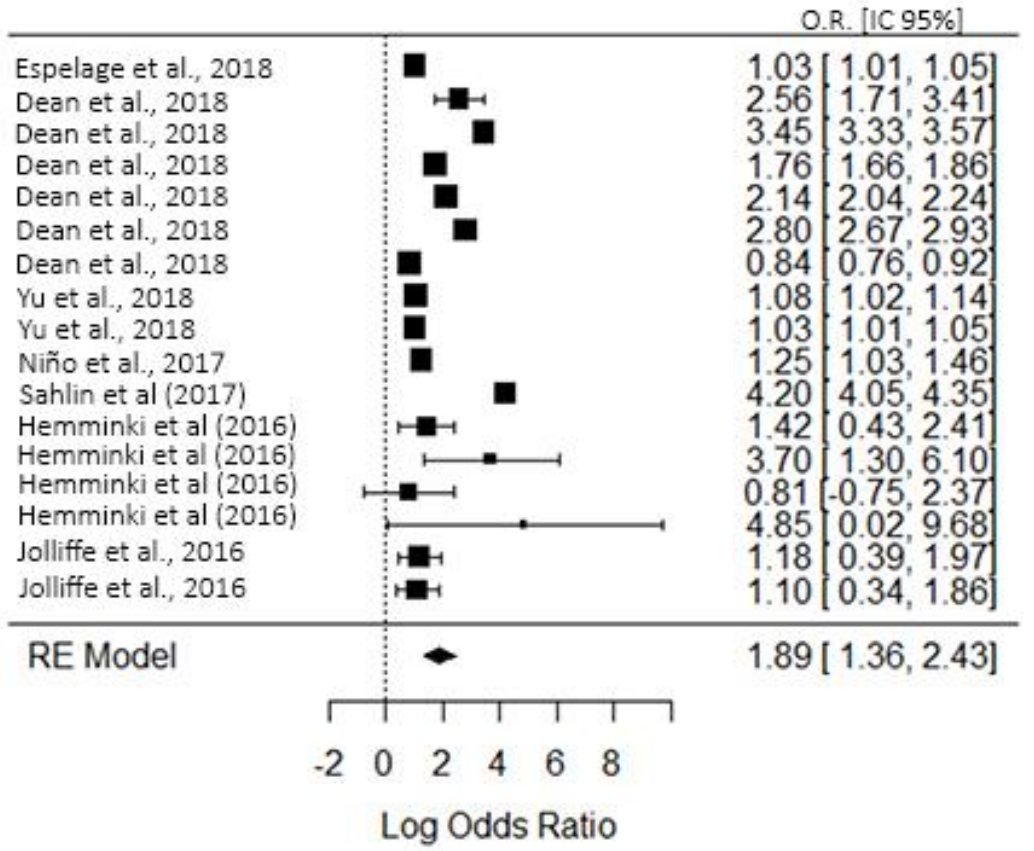

Figura 2.7. Forest plot da razão de chances de se envolver em comportamento violento dado os transtornos mentais. $\mathrm{Q}=4343$; $\mathrm{df}=17(\mathrm{p}<0,001)$; $\mathrm{I}^{2}=99,8 ; \mathrm{Z}=6,94(\mathrm{p}<0,001)$. (Fonte: autor).

Passando para os Fatores Contextuais, que indicam o modo como o indivíduo se relaciona com outras pessoas e se situa em seu entorno social, esses fatores são de natureza 
dinâmica, pois podem variar ao longo do tempo, incluso em curto espaço de tempo. Nesse domínio, três subcategorias se destacam: associação a pares infratores e envolvimento com gangues; isolamento social; inabilidade parental.

A associação a Pares Infratores - que compreende extensão da rede social e tempo despendido em atividades desestruturadas - compõe um dos principais fatores de risco para o comportamento infracional e também para a violência, como mostra a análise da Figura 2.8. A aprendizagem de comportamentos antissociais por meio da observação/imitação, do reforçamento diferencial e da pressão dos pares tem sido utilizado por muitas teorias para explicar o desenvolvimento da conduta infracional violenta e não violenta (Akers, Krohn, Lanza-Kaduce \& Radosevich, 1979; Bandura, 1977; Le Blanc, 1997; Sutherland, 1947). Um segundo fator no plano da associação a pares infratores, considerado mais significativo em termos do risco para a violência, é a afiliação na forma de pertencimento a gangues criminalizadas ou outras organizações com orientação explicitamente antissocial. O envolvimento com esse tipo de grupo organizado está intimamente ligado à prática de violências. O National Gang Intelligence Center (NGIC; 2016) define gangue como um empreendimento criminal com uma estrutura organizacional que atua continuamente em práticas criminosas, fazendo-se uso da violência para sustentar o empreendimento. $\mathrm{Na}$ perspectiva do NGIC, uma gangue consiste em um grupo de indivíduos que se organizam para atuarem continuamente em atividades criminosas, sem necessariamente possuírem uniforme, símbolo, tatuagens, ritual de iniciação ou nome. Outras definições envolvendo o conceito de gangue focam no ato criminoso, no qual um ato pode ser atribuído a uma gangue caso haja a participação de um membro da gangue e se a motivação do ato remete aos interesses da gangue (Mora \& Decker, 2018). O envolvimento em gangues caracteriza-se como um importante fator de risco por somar à associação a pares infratores o componente do compromisso com os valores da organização criminosa, na qual a aceitação e o uso da violência são intrínsecos à sobrevivência da gangue (Vigil et al., 2004). Adicionalmente, há o aspecto de vulnerabilidade dos indivíduos que em geral se afiliam a gangues, que remete a um contexto de origem caracterizado pela desorganização social e instabilidade econômica que permite que essas organizações nasçam e se estabeleçam (Curry \& Spergel, 1988; Pizzaro \& McGloin, 2004). Como mostra a Tabela 2.8, as modalidades da conduta violenta associada a frequentação de pares infratores são bastante variadas, podendo dirigir-se a outros pares, como em situação de bullying, ao parceiro íntimo ou a condutas violentas gerais. 
Tabela 2.8

Características dos estudos sobre pares infratores

\begin{tabular}{|c|c|c|c|c|c|}
\hline Autores & Estudo (País) & $\begin{array}{l}\text { Idad } \\
\text { e }\end{array}$ & $\mathbf{N}$ & V.I. & V.D. \\
\hline $\begin{array}{l}\text { Espelage et } \\
\text { al., } 2018\end{array}$ & EUA & $\begin{array}{l}10-16 \\
\text { anos }\end{array}$ & $\begin{array}{c}165 \\
5\end{array}$ & $\begin{array}{l}\text { Comportamento } \\
\text { delinquentes de pares } \\
\text { (Peer Delinquent } \\
\text { Behavior Scale; Elliott, } \\
\text { 1990) }\end{array}$ & $\begin{array}{l}\text { Agressão Relacional (tentativa } \\
\text { de causar dano a reputação da } \\
\text { outra criança/jovem (Relational } \\
\text { Aggression Scale; Crick, 1996) }\end{array}$ \\
\hline $\begin{array}{l}\text { Jung et al., } \\
2018\end{array}$ & Alemanha & $\begin{array}{l}10-19 \\
\text { anos }\end{array}$ & $\begin{array}{c}110 \\
7\end{array}$ & $\begin{array}{l}\text { Aceitação da } \\
\text { agressevidade dos } \\
\text { pares (Moller and } \\
\text { Krahé, 2009). }\end{array}$ & $\begin{array}{l}\text { Comportamento agressivo } \\
\text { (Krahé \& Moller, 2010) }\end{array}$ \\
\hline Cho, 2018 & $\begin{array}{l}\text { Korean Youth } \\
\text { Panel Study } \\
\text { (KYPS) }\end{array}$ & $\begin{array}{l}10-11 \\
\text { anos }\end{array}$ & $\begin{array}{c}284 \\
4\end{array}$ & $\begin{array}{l}\text { Afiliação a pares } \\
\text { antissociais } \\
\text { (autoinforme por } \\
\text { questionário) }\end{array}$ & $\begin{array}{l}\text { Bullying (autoinforme por } \\
\text { questionário) }\end{array}$ \\
\hline Cho, 2018 & $\begin{array}{l}\text { Korean Youth } \\
\text { Panel Study } \\
\text { (KYPS) }\end{array}$ & $\begin{array}{l}11-12 \\
\text { anos }\end{array}$ & $\begin{array}{c}284 \\
4\end{array}$ & $\begin{array}{l}\text { Afiliação a pares } \\
\text { antissociais } \\
\text { (autoinforme por } \\
\text { questionário) }\end{array}$ & $\begin{array}{l}\text { Bullying (autoinforme por } \\
\text { questionário) }\end{array}$ \\
\hline Cho, 2018 & $\begin{array}{l}\text { Korean Youth } \\
\text { Panel Study } \\
\text { (KYPS) }\end{array}$ & $\begin{array}{l}12-13 \\
\text { anos }\end{array}$ & $\begin{array}{c}284 \\
4\end{array}$ & $\begin{array}{l}\text { Afiliação a pares } \\
\text { antissociais } \\
\text { (autoinforme por } \\
\text { questionário) }\end{array}$ & $\begin{array}{l}\text { Bullying (autoinforme por } \\
\text { questionário) }\end{array}$ \\
\hline Cho, 2018 & $\begin{array}{l}\text { Korean Youth } \\
\text { Panel Study } \\
\text { (KYPS) }\end{array}$ & $\begin{array}{l}13-14 \\
\text { anos }\end{array}$ & $\begin{array}{c}284 \\
4\end{array}$ & $\begin{array}{l}\text { Afiliação a pares } \\
\text { antissociais } \\
\text { (autoinforme por } \\
\text { questionário) }\end{array}$ & $\begin{array}{l}\text { Bullying (autoinforme por } \\
\text { questionário) }\end{array}$ \\
\hline $\begin{array}{l}\text { Goodnight } \\
\text { et al., } 2017\end{array}$ & $\begin{array}{l}\text { Child } \\
\text { Development } \\
\text { Project (CDP) }\end{array}$ & $\begin{array}{l}9-23 \\
\text { anos }\end{array}$ & 466 & $\begin{array}{l}\text { Pares antissociais } \\
\text { (autoinforme por } \\
\text { questionário) }\end{array}$ & $\begin{array}{l}\text { Agressão ao parceiro íntimo } \\
\text { (Revised Conflict Tactics Scale; } \\
\text { Straus et al., 1996) }\end{array}$ \\
\hline $\begin{array}{l}\text { Goodnight } \\
\text { et al., } 2017\end{array}$ & $\begin{array}{l}\text { Child } \\
\text { Development } \\
\text { Project (CDP) }\end{array}$ & $\begin{array}{l}15-23 \\
\text { anos }\end{array}$ & 466 & $\begin{array}{l}\text { Pares antissociais } \\
\text { (autoinforme por } \\
\text { questionário) }\end{array}$ & $\begin{array}{l}\text { Agressão ao parceiro íntimo } \\
\text { (Revised Conflict Tactics Scale; } \\
\text { Straus et al., 1996) }\end{array}$ \\
\hline $\begin{array}{l}\text { McNeeley } \\
\text { \& Hoeben, } \\
2016\end{array}$ & $\begin{array}{l}\text { Study of Peers, } \\
\text { Activities and } \\
\text { Neighborhoods } \\
\text { (SPAN; } \\
\text { Holanda) }\end{array}$ & $\begin{array}{l}12-18 \\
\text { anos }\end{array}$ & 610 & $\begin{array}{l}\text { Convivência } \\
\text { social/pública não } \\
\text { estruturada }\end{array}$ & $\begin{array}{l}\text { Delinquência violenta } \\
\text { (autoinforme por questionário) }\end{array}$ \\
\hline & $\begin{array}{l}\text { The Toledo } \\
\text { Adolescent }\end{array}$ & & & & \\
\hline $\begin{array}{l}\text { Longmore } \\
\text { et al., } 2016\end{array}$ & $\begin{array}{l}\text { Relationships } \\
\text { Study (TARS; } \\
\text { EUA) }\end{array}$ & $\begin{array}{l}12-23 \\
\text { anos }\end{array}$ & 294 & $\begin{array}{l}\text { Convivência } \\
\text { social/pública não } \\
\text { estruturada }\end{array}$ & $\begin{array}{l}\text { Agressão ao parceiro íntimo } \\
\text { (Revised Conflict Tactics Scale; } \\
\text { Straus et al., 1996) }\end{array}$ \\
\hline $\begin{array}{l}\text { Jolliffe et } \\
\text { al., } 2016\end{array}$ & $\begin{array}{l}\text { Pittsburgh } \\
\text { Youth Study }\end{array}$ & $\begin{array}{l}10-19 \\
\text { anos }\end{array}$ & 503 & $\begin{array}{l}\text { Pares antissociais } \\
\text { (autoinforme por } \\
\text { questionário) }\end{array}$ & $\begin{array}{l}\text { Delinquência Violenta (registro } \\
\text { oficial e autoinforme por } \\
\text { questionário) }\end{array}$ \\
\hline
\end{tabular}

$\mathrm{VI}=$ variável independente; $\mathrm{VD}=$ Variável dependente 


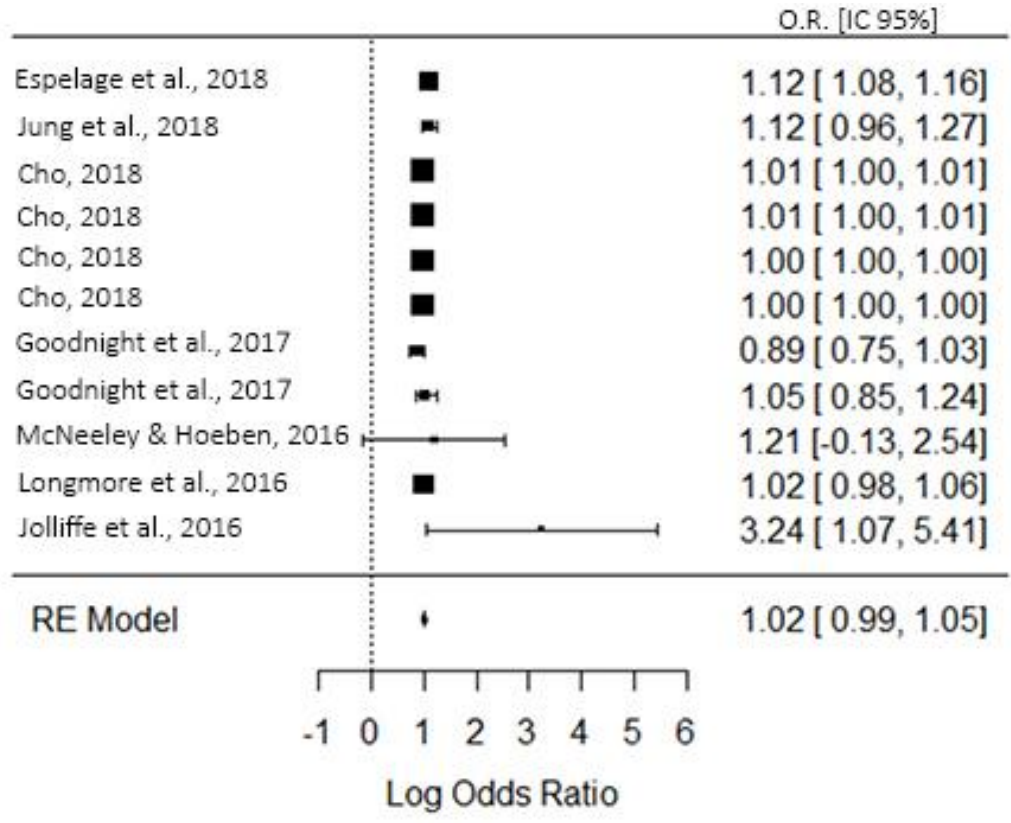

Figura 2.8. Forest plot da razão de chances de se envolver em comportamento violento dada a associação a pares infratores. $Q=4343 ; d f=17(p<0,001) ; I^{2}=99,8 ; Z=6,94(p<0,001)$. (Fonte: autor).

A segunda subcategoria contextual refere-se ao Isolamento Social, que pode ser resultado da rejeição pelos pares ou de traços de introversão acentuados que provocam uma postura ativa para evitar situações sociais. Na contramão de muitas teorias que estabelecem que o comportamento violento se desenvolve por meio de um processo de aprendizagem junto a uma rede social de modelos desviantes, o conceito de isolamento social é um aspecto incorporado especificamente na teoria da Tensão (Agnew, 1992), a qual considerou a evidência empírica de que muitos indivíduos que se implicam em delitos violentos apresentam altas pontuações em escalas que mensuram o isolamento social. Segundo a teoria, o isolamento social produz efeitos negativos, como frustração e raiva, que necessitam ser "aliviados" e o ato violento seria uma forma de fazê-lo. Nesse sentido, o efeito do isolamento social seria semelhante ao da emotividade negativa, na qual os indivíduos seriam "invadidos" por emoções negativas e necessitariam “descarregá-las”. A principal diferença entre os dois construtos seria a origem das emoções negativas; a emotividade negativa teria raízes em traços de personalidade, características predominantemente internas - relacionadas ao temperamento - enquanto o isolamento seria uma condição social-relacional. Agnew (2001) ainda estipula que a manifestação de atos antissociais como forma de descarregar a tensão é menos provável para um indivíduo se estiverem presentes, para ele, fatores protetores como sentimento de auto eficácia e valores positivos, assim como apoio social. A Tabela 2.9 e a Figura 2.9 mostram que diferentes dimensões do isolamento social estão relacionadas ao 
comportamento violento futuro, cerca de 3,7 vezes maior do que em indivíduos não expostos a esse fator.

Tabela 2.9

Características dos estudos sobre isolamento social

\begin{tabular}{|c|c|c|c|c|c|}
\hline $\begin{array}{l}\text { Autore } \\
\text { s }\end{array}$ & $\begin{array}{l}\text { Estudo } \\
\text { (País) }\end{array}$ & $\begin{array}{l}\text { Idad } \\
\text { e }\end{array}$ & n & V.I. & V.D. \\
\hline $\begin{array}{l}\text { Niño et } \\
\text { al., } \\
2017\end{array}$ & $\begin{array}{l}\text { Add Health } \\
\text { study (EUA) }\end{array}$ & $\begin{array}{l}12-18 \\
\text { anos }\end{array}$ & $\begin{array}{c}1066 \\
5\end{array}$ & $\begin{array}{l}\text { Socialmente Evitativo } \\
\text { (autoinforme por } \\
\text { questionário) }\end{array}$ & $\begin{array}{l}\text { Delinquência violenta } \\
\text { (autoinforme por questionário) }\end{array}$ \\
\hline $\begin{array}{l}\text { Niño et } \\
\text { al., } \\
2017\end{array}$ & $\begin{array}{l}\text { Add Health } \\
\text { study (EUA) }\end{array}$ & $\begin{array}{l}12-18 \\
\text { anos }\end{array}$ & $\begin{array}{c}1066 \\
5\end{array}$ & $\begin{array}{l}\text { Ativamente Isolado } \\
\text { (autoinforme por } \\
\text { questionário) }\end{array}$ & $\begin{array}{l}\text { Delinquência violenta } \\
\text { (autoinforme por questionário) }\end{array}$ \\
\hline $\begin{array}{l}\text { Niño et } \\
\text { al., } \\
2017\end{array}$ & $\begin{array}{l}\text { Add Health } \\
\text { study (EUA) }\end{array}$ & $\begin{array}{l}12-18 \\
\text { anos }\end{array}$ & $\begin{array}{c}1066 \\
5\end{array}$ & $\begin{array}{l}\text { Socialmente Desinteressado } \\
\text { (autoinforme por } \\
\text { questionário) }\end{array}$ & $\begin{array}{l}\text { Delinquência violenta } \\
\text { (autoinforme por questionário) }\end{array}$ \\
\hline $\begin{array}{l}\text { Niño et } \\
\text { al., } \\
2017\end{array}$ & $\begin{array}{l}\text { Add Health } \\
\text { study (EUA) }\end{array}$ & $\begin{array}{l}12-18 \\
\text { anos }\end{array}$ & $\begin{array}{c}1066 \\
5\end{array}$ & $\begin{array}{l}\text { Problemas com pares } \\
\text { (autoinforme por } \\
\text { questionário) }\end{array}$ & $\begin{array}{l}\text { Delinquência violenta } \\
\text { (autoinforme por questionário) }\end{array}$ \\
\hline $\begin{array}{l}\text { Jolliffe } \\
\text { et al., } \\
2016\end{array}$ & $\begin{array}{l}\text { Pittsburgh } \\
\text { Youth Study } \\
\text { (EUA) }\end{array}$ & $\begin{array}{l}10-19 \\
\text { anos }\end{array}$ & 503 & $\begin{array}{l}\text { Relação ruim com pares } \\
\text { (autoinforme por } \\
\text { questionário) }\end{array}$ & $\begin{array}{l}\text { Delinquência Violenta (registro } \\
\text { oficial e autoinforme por } \\
\text { questionário) }\end{array}$ \\
\hline $\begin{array}{l}\text { Jolliffe } \\
\text { et al., } \\
2016\end{array}$ & $\begin{array}{l}\text { Pittsburgh } \\
\text { Youth Study } \\
\text { (EUA) }\end{array}$ & $\begin{array}{l}10-19 \\
\text { anos }\end{array}$ & 503 & $\begin{array}{l}\text { Shyness/withdrawal } \\
\text { (autoinforme por } \\
\text { questionário) }\end{array}$ & $\begin{array}{l}\text { Delinquência Violenta (registro } \\
\text { oficial e autoinforme por } \\
\text { questionário) }\end{array}$ \\
\hline
\end{tabular}

$\mathrm{VI}$ = variável independente; $\mathrm{VD}=$ Variável dependente

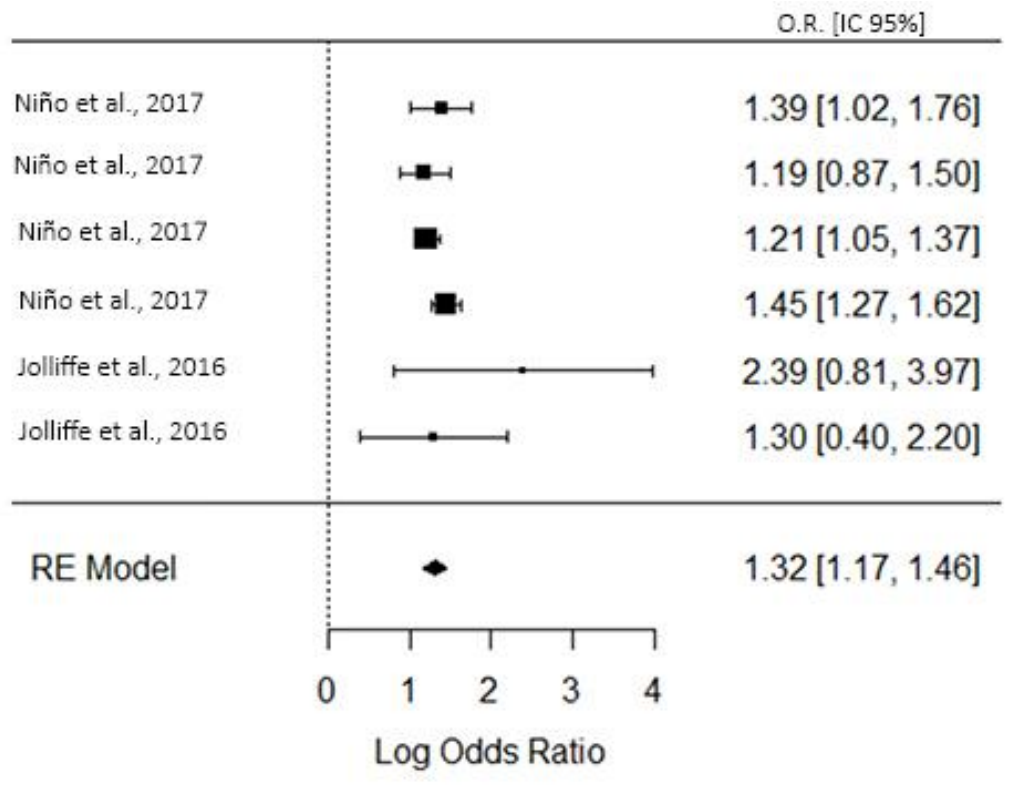

Figura 2.9. Forest plot da razão de chances de se envolver em comportamento violento dado o isolamento social. $Q=0,88 ; d f=4(p=0,828) ; I^{2}=0 ; Z=18,5(p<0,001)$. (Fonte: autor). 
Por último, a inabilidade parental consiste em um conjunto de práticas parentais negativas como a disciplina relaxada, severa ou inconsistente, e o monitoramento/supervisão ineficaz, que podem produzir os seguintes efeitos na criança ou no adolescente: enfraquecimento do vínculo com os pais e/ou outras figuras de autoridade, associação a modelos desviantes (quando o monitoramento é ineficaz), baixa tolerância à frustração ou o tédio (quando os adultos permitem que a criança faça de tudo e a qualquer hora) ou trauma (quando a disciplina é severa) (Davies \& Davidson, 2001; Hoeve, Dublas, Eichelsheim, Van der Laan, Smeenk \& Gerris, 2009). A Tabela 2.10 e a Figura 2.10 mostram a associação de diferentes práticas parentais negativas e o subsequente e significativo envolvimento em comportamentos violentos, três vezes maior em indivíduos sob práticas parentais inábeis.

Tabela 2.10

Características dos estudos sobre inabilidade parental

\begin{tabular}{|c|c|c|c|c|c|}
\hline Autores & Estudo (País) & $\begin{array}{l}\text { Idad } \\
\text { e }\end{array}$ & $\mathbf{n}$ & V.I. & V.D. \\
\hline $\begin{array}{l}\text { Theobald } \\
\text { et al., } 2016\end{array}$ & $\begin{array}{l}\text { Cambridge } \\
\text { Study in } \\
\text { Delinquent } \\
\text { Development } \\
\text { (Reino Unido) }\end{array}$ & $\begin{array}{l}8-32 \\
\text { anos }\end{array}$ & 152 & $\begin{array}{l}\text { Sofrer punição física } \\
\text { (autoinforme por } \\
\text { questionário) }\end{array}$ & $\begin{array}{l}\text { Agressão ao parceiro íntimo } \\
\text { (Revised Conflict Tactics Scale } \\
\text { (Straus, Hamby, Boney- } \\
\text { McCoy, \& Sugarman, 1996) }\end{array}$ \\
\hline $\begin{array}{l}\text { Theobald } \\
\text { et al., } 2016\end{array}$ & $\begin{array}{l}\text { Cambridge } \\
\text { Study in } \\
\text { Delinquent } \\
\text { Development } \\
\text { (Reino Unido) }\end{array}$ & $\begin{array}{l}8-32 \\
\text { anos }\end{array}$ & 152 & $\begin{array}{l}\text { Baixa supervisão } \\
\text { parental (autoinforme } \\
\text { por questionário) }\end{array}$ & $\begin{array}{l}\text { Agressão ao parceiro íntimo } \\
\text { (Revised Conflict Tactics Scale } \\
\text { (Straus, Hamby, Boney- } \\
\text { McCoy, \& Sugarman, 1996) }\end{array}$ \\
\hline $\begin{array}{l}\text { Theobald } \\
\text { et al., } 2016\end{array}$ & $\begin{array}{l}\text { Cambridge } \\
\text { Study in } \\
\text { Delinquent } \\
\text { Development } \\
\text { (Reino Unido) }\end{array}$ & $\begin{array}{l}8-32 \\
\text { anos }\end{array}$ & 152 & $\begin{array}{l}\text { Conflitos dos pais } \\
\text { (autoinforme por } \\
\text { questionário) }\end{array}$ & $\begin{array}{l}\text { Agressão ao parceiro íntimo } \\
\text { (Revised Conflict Tactics Scale } \\
\text { (Straus, Hamby, Boney- } \\
\text { McCoy, \& Sugarman, 1996) }\end{array}$ \\
\hline $\begin{array}{l}\text { Henneberg } \\
\text { er et al., } \\
2016\end{array}$ & $\begin{array}{l}\text { Multisite Violence } \\
\text { Prevention Project } \\
\text { (EUA) }\end{array}$ & & $\begin{array}{c}123 \\
2\end{array}$ & $\begin{array}{l}\text { Supervisão parental ( } \\
\text { Pittsburgh Youth } \\
\text { Survey (PYS; } \\
\text { Thornberry, Huizinga, } \\
\text { \& Loeber, 1995) }\end{array}$ & $\begin{array}{l}\text { Comportamento agressivo } \\
\text { (Problem Behavior Frequency } \\
\text { Scale (PBFS; Farrell, Kung, } \\
\text { White, \& Valois, 2000) }\end{array}$ \\
\hline $\begin{array}{l}\text { Jolliffe et } \\
\text { al., } 2016\end{array}$ & $\begin{array}{l}\text { Pittsburgh Youth } \\
\text { Study (EUA) }\end{array}$ & $\begin{array}{l}10- \\
19 \\
\text { anos }\end{array}$ & 503 & $\begin{array}{l}\text { Disciplina } \\
\text { inconsistente } \\
\text { (autoinforme por } \\
\text { questionário) }\end{array}$ & $\begin{array}{l}\text { Delinquência Violenta (registro } \\
\text { oficial e autoinforme por } \\
\text { questionário) }\end{array}$ \\
\hline $\begin{array}{l}\text { Jolliffe et } \\
\text { al., } 2016\end{array}$ & $\begin{array}{l}\text { Pittsburgh Youth } \\
\text { Study (EUA) }\end{array}$ & $\begin{array}{l}10- \\
19 \\
\text { anos }\end{array}$ & 503 & $\begin{array}{l}\text { Disciplina não } \\
\text { reforçadora } \\
\text { (autoinforme por } \\
\text { questionário) }\end{array}$ & $\begin{array}{l}\text { Delinquência Violenta (registro } \\
\text { oficial e autoinforme por } \\
\text { questionário) }\end{array}$ \\
\hline $\begin{array}{l}\text { Jolliffe et } \\
\text { al., } 2016\end{array}$ & $\begin{array}{l}\text { Pittsburgh Youth } \\
\text { Study (EUA) }\end{array}$ & $\begin{array}{l}10- \\
19 \\
\text { anos }\end{array}$ & 503 & $\begin{array}{l}\text { Não envolvimento } \\
\text { com atividades da } \\
\text { família (autoinforme }\end{array}$ & $\begin{array}{l}\text { Delinquência Violenta (registro } \\
\text { oficial e autoinforme por } \\
\text { questionário) }\end{array}$ \\
\hline
\end{tabular}




\begin{tabular}{|c|c|c|c|c|c|}
\hline & & & & por questionário) & \\
\hline $\begin{array}{l}\text { Jolliffe et } \\
\text { al., } 2016\end{array}$ & $\begin{array}{l}\text { Pittsburgh Youth } \\
\text { Study (EUA) }\end{array}$ & $\begin{array}{l}10- \\
19 \\
\text { anos }\end{array}$ & 503 & $\begin{array}{l}\text { Punição física } \\
\text { (autoinforme por } \\
\text { questionário) }\end{array}$ & $\begin{array}{l}\text { Delinquência Violenta (registro } \\
\text { oficial e autoinforme por } \\
\text { questionário) }\end{array}$ \\
\hline $\begin{array}{l}\text { Jolliffe et } \\
\text { al., } 2016\end{array}$ & $\begin{array}{l}\text { Pittsburgh Youth } \\
\text { Study (EUA) }\end{array}$ & $\begin{array}{l}10- \\
19 \\
\text { anos }\end{array}$ & 503 & $\begin{array}{l}\text { Supervisão parental } \\
\text { ausente (autoinforme } \\
\text { por questionário) }\end{array}$ & $\begin{array}{l}\text { Delinquência Violenta (registro } \\
\text { oficial e autoinforme por } \\
\text { questionário) }\end{array}$ \\
\hline
\end{tabular}

$\mathrm{VI}$ = variável independente; $\mathrm{VD}=$ Variável dependente

O.R. [IC 95\%]

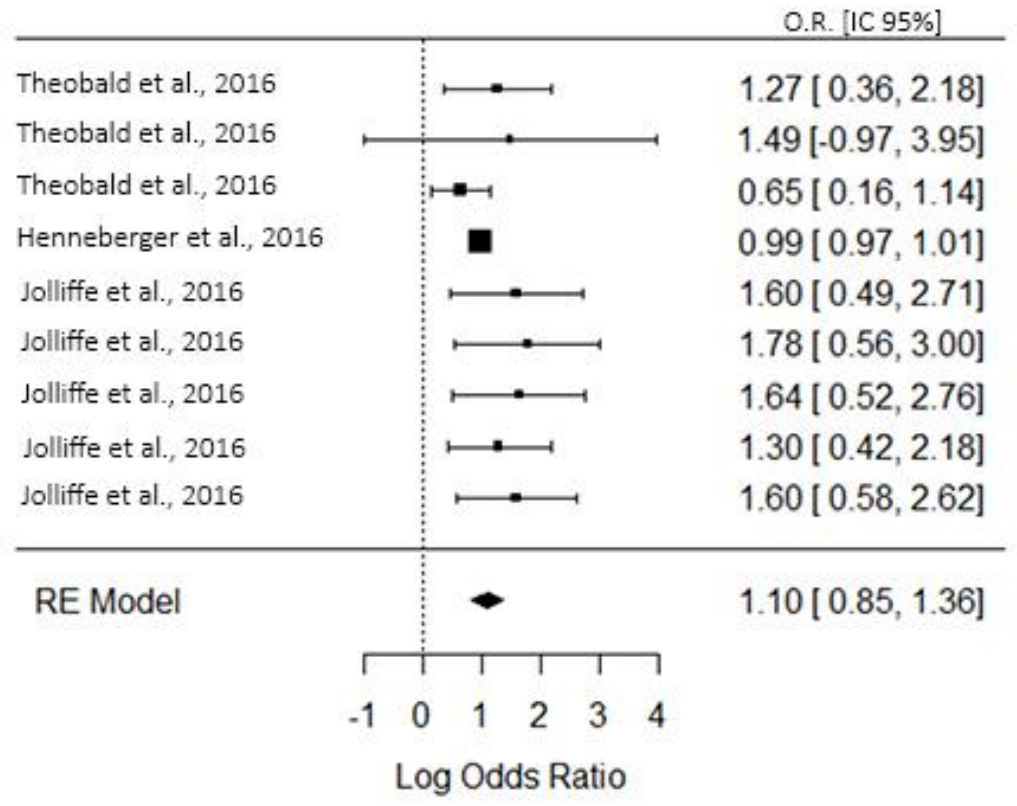

Figura 2.10. Forest plot da razão de chances de se envolver em comportamento violento dado a inabilidade parental. $\mathrm{Q}=8,24 ; \mathrm{df}=9(\mathrm{p}=0,409) ; \mathrm{I}^{2}=25,6 ; \mathrm{Z}=8,39(\mathrm{p}<0,001)$. (Fonte: autor).

Concluindo, a presente seção descreveu os principais fatores de risco (Tabela 2.11) para a conduta violenta e os analisou em termos quantitativos (combinação dos efeitos identificados pelos estudos revisados) e qualitativos (relação teórica com a conduta violenta). Há, certamente, indivíduos expostos a um ou mais desses fatores e que não desenvolvem um padrão de conduta violenta em razão do processo de resiliência fomentado por fatores protetores, tema do próximo tópico. 
Tabela 2.11

Sintese dos fatores de risco mais relevantes para a conduta violenta

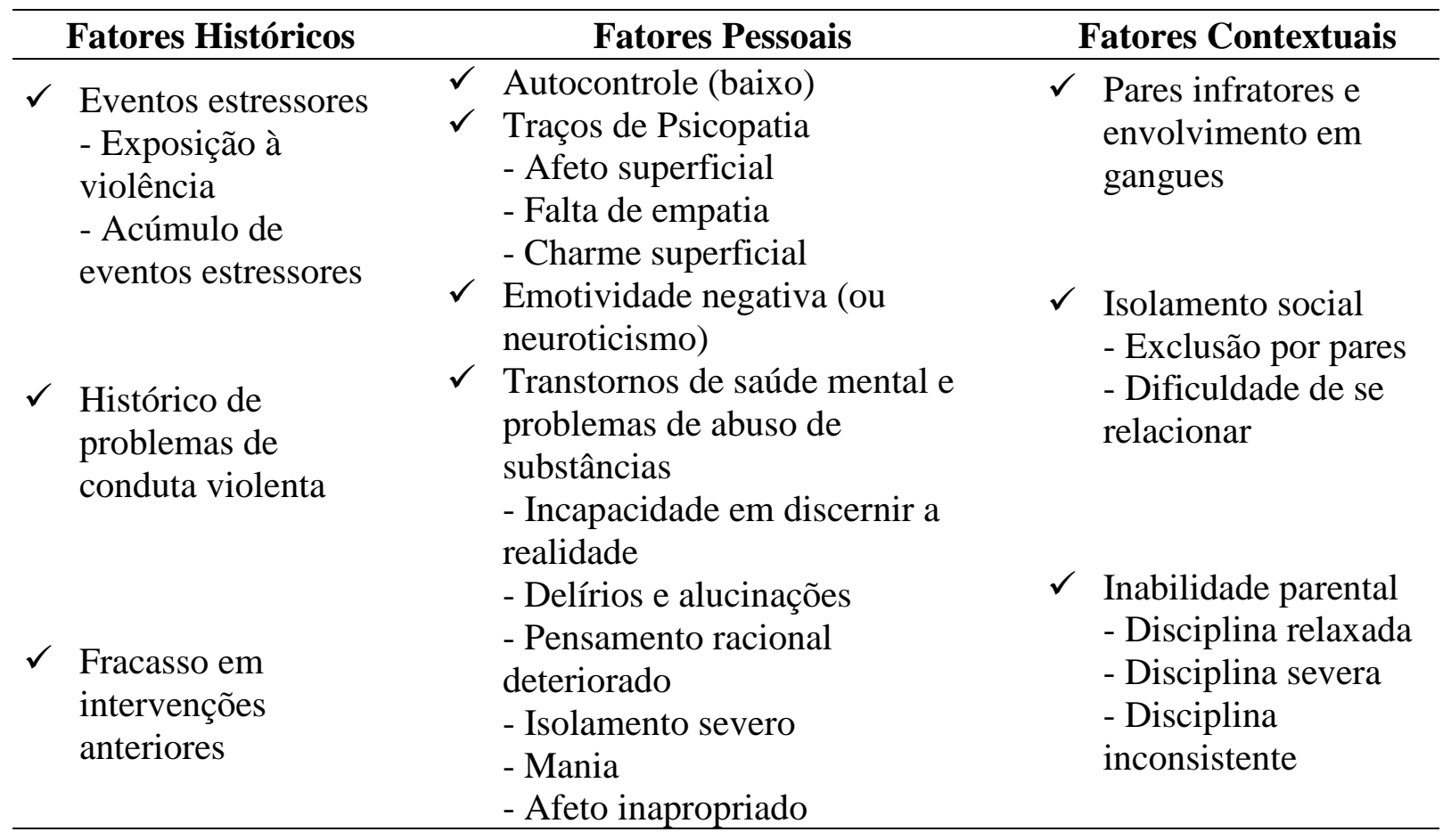

\subsubsection{Os fatores de proteção para a conduta violenta}

A maioria dos estudos e dos protocolos de ARV focalizam principalmente, quando não exclusivamente, os fatores de risco, e negligenciam os fatores protetores. Isso se deve, possivelmente, ao fato de os fatores de risco serem mais fáceis de se identificar, pois são numerosos - há uma grande quantidade de fatores que reconhecidamente promovem risco. Em contraste, identificar os fatores protetores relevantes representa uma tarefa mais desafiadora, pois significa identificar variáveis que hajam mediante os fatores de risco, efetivamente diminuindo / eliminando seus efeitos, com a ressalva de que, isoladamente, essas variáveis podem não ter significado. Apesar da reduzida literatura referente aos fatores de proteção para a violência, esses precisam ser levados em consideração para evitar que a ARV não seja desequilibrada, o que poderia gerar uma grande quantidade de falsos-positivos casos em que indivíduos avaliados como de alto risco não reincidem (DeMatteo, Heilbrun \& Marczyk, 2005; Komatsu, Wenger, Costa, Bazon \& Andrés-Pueyo, 2019).

Seguindo o critério de agrupamento do Structured Assessment of Protective Factors (SAPROF; Vogel, de Vries Robbé, Ruiter \& Bouman, 2011), os fatores de proteção apresentados nesta seção foram agrupados nas seguintes categorias: internos, motivacionais e 
externos (conforme se lê na Tabela 2.12) ${ }^{7}$. Os fatores internos referem-se a características da pessoa como autocontrole, empatia e inteligência. Os motivacionais referem-se a indicadores que representam o interesse do indivíduo em participar da sociedade de forma positiva como engajamento em atividades pró-sociais, metas de vida pró-social e atitudes positivas frente à autoridade. Os fatores externos referem-se a variáveis - características ou situações - do entorno social ou relacionais como apoio social e forte vínculo com instituições/adultos pró-sociais.

Tabela 2.12

Síntese dos fatores de proteção mais relevantes para a conduta violenta

\begin{tabular}{|c|c|c|c|}
\hline & Fatores Internos & Fatores Motivacionais & Fatores Externos \\
\hline & Autocontrole & $\begin{array}{ll}\checkmark & \text { Atitudes positivas } \\
& \text { frente às autoridades }\end{array}$ & $\checkmark \quad$ Apoio social \\
\hline & Empatia & ou às intervenções & $\checkmark$ Vínculo com \\
\hline & Inteligência & $\begin{array}{l}\checkmark \text { Comprometimento } \\
\quad \text { com escola / trabalho }\end{array}$ & $\begin{array}{l}\text { instituições/adultos pró- } \\
\text { sociais }\end{array}$ \\
\hline
\end{tabular}

O autocontrole é uma variável mista, isto é, pode atuar como risco ou como proteção para a conduta violenta. Como descrito anteriormente, problemas ou dificuldades em exercer o autocontrole é fator de risco para desenvolver padrões de comportamento violento. Na outra extremidade dessa medida encontra-se o exercício eficaz do autocontrole, caracterizando indivíduos capazes de estabelecer e seguir metas de médio e longo prazo, de postergar reforços imediatos para obter resultados mais significativos no futuro, de ponderar as consequências de suas ações e de regular impulsos e reações emotivas (de Vries Robbé, Mann, Maruna \& Thornton, 2014; Diamond, 2013). O autocontrole é um dos fatores internos avaliados por instrumentos estruturados como Structured Assessing of PROtective Factors (SAPROF), único protocolo de ARV que foca exclusivamente em fatores protetores, devido ao acúmulo de evidências indicando sua função protetora. O estudo de Vassallo, Edwards e Forrest (2016), com mais de mil jovens adolescentes do Australian Temperament Project, identificou que altos escores em autocontrole em qualquer período da adolescência correspondem consistentemente a menores chances de se envolver em condutas violentas no início da vida adulta. Estudos em outros contextos corroboram esse resultado (Jolliffe,

\footnotetext{
${ }^{7}$ Não foi possível realizar metanálise nessa parte porque o número de artigos levantados concernindo alguns construtos não foi suficiente e/ou os resultados da forma como foram apresentados eram incompatíveis, um em relação aos outros, de forma que não foi possível agrupá-los.
} 
Farrington, Loeber \& Pardini, 2016; Thompson \& Swartout, 2018). Ademais, o autocontrole não só atua como fator protetivo contra o envolvimento com a delinquência e com a violência como também se associa a resultados positivos em várias esferas da vida (Moffitt et al., 2011). A capacidade de exercer autocontrole se desenvolve especialmente na infância e na adolescência por meio dos processos de socialização, mas também há evidências de que pode ser desenvolvida em outros períodos da vida por meio de treinamentos específicos (Komatsu, Costa \& Bazon, 2018).

O segundo fator interno remete ao conceito de empatia, definido como a capacidade de perceber e de entender as emoções, sentimentos e percepções de outra pessoa, do ponto de vista dela (APA, 2015). A capacidade e o hábito de se pôr no lugar do outro permite a construção de relações mais positivas, de modo que atribuições de intenções hostis ou negativas aos outros ocorrem com menor frequência, diminuindo as oportunidades de se sentir com raiva ou frustrado (condições emocionais que, como se indicou, aumentam a probabilidade de conduta violento). A empatia também eleva o custo de condutas violentas, pois os mecanismos a ela inerentes (emocional e cognitivo) contribuem para aumentar o constrangimento interno, inibindo respostas violentas. Cabe mencionar que o desenvolvimento da empatia é favorecido por relações positivas com adultos e pelo sentimento de vinculação, especialmente na infância (de Vries Robbé, Geers, Stapel, Hilterman \& Vogel, 2015), sendo desfavorecido por práticas de abuso e de maus-tratos (Miller \& Eisenberg, 1988).

O terceiro fator interno destacado é a inteligência, definida como habilidade de derivar informação, de aprender com a experiência, de adaptar-se aos ambientes e de utilizar corretamente o pensamento e a razão (APA, 2015). Diferentes estudos têm identificado a inteligência como um aspecto pessoal protetor. No estudo de Andershed, Gibson e Andershed (2016), por exemplo, 519 indivíduos foram acompanhados dos 10 aos 47 anos, tendo-se constatado que indivíduos avaliados com inteligência alta durante a adolescência se envolveram menos em delitos violentos ao longo da vida. A inteligência se mostra bastante relacionada às funções executivas e, portanto, à capacidade de exercer apropriadamente o autocontrole (Arffa, 2007; Duggan \& Garcia-Barrera, 2015). Boas capacidades cognitivas também favorecem o bom desempenho em atividades pró-sociais, afastando o adolescente de oportunidades antissociais (Le Blanc, 1997). Os estudos também mostram que crianças com boas capacidades de aprendizado e de solução de problemas são mais bem-sucedidas em se recuperar de adversidades crônicas na infância (Masten et al., 1990; Ttofi, Farrington, Piquero, Losel, DeLisi \& Murray, 2016). Adicionalmente, quando os adultos percebem o 
potencial cognitivo das crianças tendem a dar mais atenção a elas, aumentando sua estimulação, fortalecendo os vínculos e ampliando as oportunidades de lograrem prósocialmente (Britto \& Lomonaco, 1983).

Passando para os fatores motivacionais, o primeiro deles refere-se à atitude positiva frente às regras e à autoridade. Uma atitude positiva representaria um conjunto de valores internalizados pelo indivíduo atinentes à disposição a cumprir as regras e os acordos estabelecidos, a respeitar professores e outras figuras adultas (Andrews \& Bonta, 2010; de Vries Robbé \& Vogel, 2013). Em meio a adolescentes em conflito com a lei, a atitude positiva em relação às intervenções e às autoridades aponta para um bom prognóstico com relação à não reincidência, constituindo-se, portanto, um importante indicador para a ARV, sendo, por isso, considerado nas avaliações realizadas com os principais protocolos de ARV como o Structured Assessment of Violence Risk in Youth (SAVRY; Borum, Bartel \& Forth, 2006) e o SAPROF (de Vries Robbé, Geers, Stapel, Hilterman \& de Vogel, 2015). O estudo de Komatsu e colegas (2019) junto a 858 adolescentes em conflito com a lei identificou que o efeito protetor de variáveis como atitude positiva à intervenção e motivação para a mudança equivale ao efeito protetor de variáveis sociais como apoio social, vínculo a instituições/adultos pró-sociais e engajamento em atividades pró-sociais.

$\mathrm{O}$ segundo fator protetor de natureza motivacional remete ao compromisso e ao vínculo com a escola e/ou o trabalho, mais do que apenas bons resultados escolares ou laborais (Borum, Bartel \& Forth, 2006). Segundo os autores, para ser considerado fator de proteção esse engajamento escolar ou laboral deve estar em um nível acima da média, comparativamente ao verificado em outros jovens pró-sociais. Um forte compromisso com essas instituições aumenta as oportunidades de desenvolvimento de habilidades importantes para a vida, concorre para os jovens ocuparem seu tempo com atividades pró-sociais (reduzindo o tempo para atividades não estruturadas) e amplia a rede social de pares e de adultos pró-sociais. Nesse sentido, o interesse em ter êxito na escola ou no trabalho conduziria os jovens a uma rotina e a uma rede social protetoras que reduziria o risco de se envolver em condutas violentas. Para os indivíduos com forte vínculo escolar ou laboral, o envolvimento em condutas violentas se torna mais custoso, pois colocaria em risco as metas de vida e as relações estabelecidas nessa rede formada por pares e adultos pró-sociais.

Por último, passando para os fatores externos, o apoio social se refere ao suporte oferecido por pelo menos uma figura adulta, para as tarefas cotidianas (Borum, Bartel \& Forth, 2006). Essa figura deve estar frequentemente disponível e a criança ou o adolescente deve se sentir à vontade para solicitar ajuda diante de diferentes demandas, como uma tarefa 
escolar, um mal estar físico ou emocional, entre outras. Nesse sentido, adultos - pais e mães que passam o dia todo fora de casa e não conseguem prover outra figura para substituir suas funções, mesmo que tenham orientação pró-social, podem não se constituir em figura de apoio. O apoio social de adultos pró-sociais protegem o adolescente de se envolver em atividades ou em situações de risco e também auxiliam no processo de socialização, ao oferecer modelos de conduta e ao reprovarem comportamentos desviantes e reforçarem comportamentos adequados, favorecendo o desenvolvimento pleno do adolescente (Andrews \& Bonta, 2010).

Para além do suporte social, os estudos também indicam que a vinculação com instituições/adultos que demonstrem afeto e aceitação consiste em um importante fator de proteção contra o envolvimento em violência (Atwool, 2007; Franke, 2000). O vínculo de um indivíduo com a sociedade pode se manifestar em diferentes esferas da vida de uma pessoa. $\mathrm{O}$ relacionamento do indivíduo com instituições/adultos pró-sociais pode ser entendido por meio de dois conceitos: apego e empenho (Le Blanc, 1997). O elemento mais importante do vínculo de um indivíduo a uma sociedade convencional consiste no apego às pessoas. Se uma pessoa é sensível à opinião dos outros, então ela se sente na obrigação de aderir às suas normas. $\mathrm{O}$ apego às pessoas pró-sociais pode anular as influências criminosas, mas um apego fraco ou fragmentado aumenta a suscetibilidade a essas influências. Já o empenho refere-se a uma atitude de aceitação dessas instituições ou figuras adultas e reflete em um investimento de tempo e esforço para com elas. Se o empenho for forte, aderir a comportamentos infracionais se torna "custoso". Uma pessoa que está tentada a cometer um crime vai avaliar os custos desse comportamento em relação ao investimento que já foi feito e o que ele espera alcançar nessas instituições (Le Blanc, 1997; Catalano \& Hawkings, 2005).

Em resumo, a presente seção destacou a importância dos fatores de proteção para o desenvolvimento humano, mediante os riscos para o envolvimento em delitos violentos. Tanto as ARV quanto as intervenções devem levar esses fatores em consideração. As ARV necessitam balancear adequadamente os fatores de risco com os de proteção para obter um diagnóstico preciso da situação de cada adolescente. As intervenções, igualmente, devem visar a promoção desses fatores e não só a atenuação/eliminação dos fatores de risco. 


\subsection{Teorias relativas à delinquência juvenil na perspectiva da Criminologia Desenvolvimental}

À luz das inúmeras investigações sobre os fatores de risco e de proteção associados ao desenvolvimento da conduta delituosa na adolescência, diversas teorias visando explicar o engajamento infracional foram elaboradas, cada uma priorizando um conjunto particular de fatores ou domínios relevantes. À título de síntese, explana-se brevemente sobre algumas das teorias contemporâneas mais proeminentes, a partir da obra Integrated Developmental and Life-course Theories of Offending (Farrington, 2005a). Elas serão sintetizadas a seguir com alguns acréscimos de publicações posteriores dos referidos autores. A ordem de apresentação não seguiu nenhum critério de importância, apenas a própria ordem em que elas aparecem na obra de Farrington.

Benjamin Lahey e Irwin Waldman (Lahey \& Waldman, 2005), com dados do Developmental Trends Study, desenvolveram um modelo teórico que fornece um conjunto de fatores de natureza pessoal - temperamento e cognição - que contribuiria para o desenvolvimento da propensão antissocial e problemas de saúde mental relacionados. Assim, a despeito de outros fatores, indivíduos com essas características estariam mais propensos a desenvolverem problemas de conduta, segundo os autores. O primeiro fator destacado é o traço de emotividade negativa, que caracteriza indivíduos que ressentem mais marcadamente emoções negativas (ex: frustração, irritação e tédio). O segundo é a audácia (daring), um traço que mescla aspectos dos construtos de desinibição comportamental, de busca por sensações e de busca por estímulos novos. O terceiro traço é o da baixa pró-socialidade, caracterizada por baixos níveis de simpatia, empatia e preocupação com os outros. Adicionalmente às três dimensões do temperamento, os autores estipulam que um baixo nível de habilidades cognitivas (inteligência, disfunção neuropsicológica e funcionamento executivo) e atraso no desenvolvimento verbal também contribuem à propensão antissocial. Apesar do foco em características pessoais com forte componente hereditário, os autores reconhecem que as influências ambientais são importantes para o surgimento/desenvolvimento desses déficits na infância e na adolescência.

Terrie Moffitt (1993) possui a mais conhecida das teorias da Criminologia Desenvolvimental, tendo por base as mais de 5.000 citações contabilizadas pelo Scopus e 10.000 pelo Google Scholar. Com dados do Dunedin Longitudinal Study e de revisão da literatura, a autora propõe duas categorias de delinquência juvenil, levando em conta padrões de conduta delituosa: os limitados à adolescência (adolescence-limited [AL]) e os persistentes 
no curso da vida (life-course-persistent [LCP]). Os principais fatores relacionados à conduta delituosa dos infratores AL remetem à imaturidade e à influência dos pares; os adolescentes apresentando esse padrão de conduta tenderiam a parar de infracionar com o avançar da idade. Em relação aos infratores LCP, os principais fatores relacionados são os déficits neurodesenvolvimentais como baixos níveis de autocontrole e de habilidades cognitivas, práticas parentais ruins, desorganização familiar e baixa renda; os adolescentes apresentando esse padrão de conduta tenderiam a continuar infracionando na vida adulta. Dessa forma, a autora estipula que as subfuncionalidades neuropsicológicas e as condições ambientais adversas interagem de forma a produzir uma propensão antissocial. Na mais recente revisão de sua teoria, Moffitt (2018) inclui achados de estudos que na época em que a teoria foi formulada não estavam disponíveis, como métodos de associação genômica e de neuroimagem, e também aspectos ambientais como o baixo apego à figura materna e a experiência de disciplina severa como características marcantes dos LCP. A teoria de Moffitt é a teoria desenvolvimental mais testada, e tem resistido aos testes, mostrando sua robustez teórica-empírica.

David Farrington (2005b), o criminólogo mais notório dessa lista, também desenvolveu sua Teoria Integrada do Potencial Antissocial Cognitivo (Integrated Cognitive Antisocial Potential [ICAP]) para explicar o envolvimento de adolescentes de classe médiabaixa em atividades delituosas, tendo como base empírica os dados do The Cambridge Study of Delinquency. A ICAP integra conceitos das teorias da Tensão, do Controle, do Aprendizado, da Rotulação e da Escolha Racional, mas tem como conceito chave o Potencial Antissocial (PA; definido como potencial para cometer delitos). A teoria estabelece que o PA se desenvolve em comportamento antissocial, ou seja, o potencial se concretiza em ação, a partir da cognição (pensamento e escolha) sobre as oportunidades e as vítimas. Farrington (2005b) postula o PA de longo prazo e o PA de curto prazo para distinguir o efeito que as variáveis exercem sobre o indivíduo. Entre as variáveis associadas ao PA de longo prazo estão a impulsividade, a tensão, a modelagem, os processos socializadores e os eventos de vida. Em relação ao PA de curto prazo estariam os fatores situacionais (oportunidade) e motivacionais (utilitarismo). Dessa forma, a ICAP estabelece que o cometimento de delito depende da interação entre o nível imediato de PA do indivíduo e as oportunidades ambientais, sendo mediado por um processo cognitivo de escolha racional (relação custo-benefício). Farrington (2014) ressalta que as pessoas tendem a fazer escolhas que pareçam racionais a elas, mas que indivíduos com baixos níveis de PA não cometeriam delitos mesmo diante uma situação que pareça racional cometer. 
Catalano e Hawkins (1996), com base nos dados do Seattle Social Development Project, constroem seu Modelo de Desenvolvimento Social (Social Development Model [SDM]) a partir da integração das teorias do Controle Social, Aprendizagem Social e Associação Diferencial. Os autores identificam processos de socialização que ocorrem em quatro importantes fases - pré-escola, educação infantil, ensino fundamental e ensino médio que se relacionam ao desenvolvimento do engajamento infracional. A transição entre cada fase é acompanhada por mudanças ambientais que produzem diferentes processos socializadores. O SDM possui modelos específicos para cada fase, nos quais diferentes variáveis podem atuar de forma distinta. Segundo a teoria, as crianças precisam e vão aprender padrões de comportamentos, sejam pró-sociais ou antissociais, e elas vão aprender em unidades socializadoras como famílias, escola, religião e pares. E essa socialização ocorre por meio de quatro processos: percepção de oportunidades para se envolver em atividades e interações com os outros; o grau de envolvimento e de interação; as habilidades para participar das interações; os reforços que podem vir com essas interações. Quando esses processos socializadores ocorrem de forma consistente, forma-se um vínculo social com essas unidades socializadoras, capaz de criar um controle informal e afetar o comportamento futuro em consonância com os valores dessas unidades. O SDM estabelece uma relação causal entre vínculo forte e afetivo com pares antissociais e comportamento antissocial, sendo este um dos aspectos que o diferenciam da teoria do Controle de Hirschi (1969), que caracteriza a relação entre pares desviantes como fria e frágil. Assim, o comportamento antissocial poderia surgir em três situações: 1. Quando não se desenvolve vínculos pró-sociais e, portanto, há poucos constrangimentos internos; 2. Quando o custo do delito é muito baixo e o benefício é muito alto (escolha racional baseada no custo-benefício, independente do vínculo); 3. Quando o vínculo estabelecido remete a unidades socializadoras que possuem valores antissociais.

Marc Le Blanc (1997), com base no Montreal Two Samples Longitudinal Study, desenvolveu uma teria integrativa que explica o fenômeno criminal em seus três níveis: taxas de crimes em uma sociedade (criminalidade), ocorrência de um determinado delito (crime) e desenvolvimento da conduta delituosa (o infrator/o criminoso). No nível da pessoa do infrator, a teoria Integrativa do Controle Social e Pessoal estabelece quatro mecanismos que se relacionam de forma causal à conduta delituosa: vínculos com a sociedade (apego e empenho à família, escola, religião, pares), modelos (pró-sociais ou antissociais), constrangimentos (internos ou externos) e o autocontrole. Assim, o indivíduo desenvolveria um padrão de comportamento antissocial ou pró-social a partir da qualidade e da interação entre esses quatro mecanismos. Além disso, o autor estabelece dois conjuntos de fatores 
contextuais que influenciam a dinâmica entre os mecanismos, mas não implicam causalidade: o background social e cultural e as capacidades biológicas do indivíduo. Le Blanc (2003, 2009) também postula que as trajetórias de comportamento antissocial podem ser representadas por três meta-trajetórias: delinquência comum, transitória e distintiva. A delinquência comum e a delinquência distintiva se assemelham aos AL e LCP da taxonomia de Moffitt (1993, 2018), enquanto a trajetória de delinquência transitória se posicionaria, em termos de controle e de suscetibilidade às oportunidades, em um nível intermediário entre essas duas categorias. A teoria de Le Blanc é, segundo Farrington e Ttofi (2015), a mais complexa das teorias criminológicas desenvolvimentais.

Robert Sampson e John Laub (2005), com base nos dados do estudo longitudinal Unraveling Juvenile Delinquency de Sheldon e Eleanor Glueck, identificaram que o fator mais forte e mais consistente relacionado à conduta delituosa oficial e autorrevelada eram os processos de controle social informal exercido pelas instituições família, escola e pares. Os fatores familiares relacionados à delinquência seriam os níveis inadequados de supervisão, a disciplina severa e/ou inconsistente e o fraco vínculo familiar. Em âmbito escolar, o principal fator seria o baixo vínculo com a escola/estudos. E em relação aos pares, a associação a pares antissociais estaria fortemente relacionado ao envolvimento com a delinquência. Entre as constatações das análises de Sampson e Laub, destacam-se que fatores como background social e predisposições temperamentais possuíam pouco efeito direto na delinquência, diferentemente do que muitas das outras teorias estipulam. Portanto, variáveis de background estrutural e social (renda, etnia, tamanho da família) e de natureza pessoal (temperamento, capacidades cognitivas) atuariam de forma indireta por meio de seus efeitos sobre os processos socializadores e sobre o controle social informal. Em consequência, os autores focam na importância dos agentes de controle informal e destacam a importância dos "pontos de virada" ao longo da vida, ocasionados por transformações sócio-relacionais atreladas à idade. Assim, os autores estipulam que a continuidade / à descontinuidade da delinquência na vida adulta depende dos eventos sociais que acompanham essa transição, como a participação no serviço militar, o envolvimento com algum trabalho estável, o casamento, entre outros.

Terence Thornberry (1987) propõe a Teoria Interacional da Delinquência, na qual o comportamento antissocial seria consequência de vínculos sociais frágeis e do envolvimento com uma rede de pares infratores. Porém, a própria conduta delituosa também atuaria para fragilizar os vínculos sociais e para fortalecer as crenças antissociais e aumentar a rede de pares infratores. Os autores observam que os vínculos sociais frágeis atuam como uma espécie de "liberdade de se comportar", permitindo que a pessoa cometa delitos, embora não 
seja uma causa direta do comportamento em si. Então, para o delito ocorrer, seria necessário um ambiente de aprendizagem específico, que no caso seria a associação a pares infratores e a adoção a valores antissociais. Posteriormente, fruto de trabalho em conjunto com Marvin Krohn (Thornberry \& Krohn, 2001, 2005), a teoria se ampliou e passou a incorporar outros aspectos desenvolvimentais. Os autores atribuem o início da manifestação dos comportamentos antissociais, na infância, a características individuais (traços de impulsividade, assunção de riscos e emotividade negativa), à parentalidade ineficaz (monitoramento e disciplina) e à desvantagem social (pobreza crônica, desemprego, residência em área concentrada de pobreza). Quando os comportamentos antissociais se iniciam na adolescência, os autores atribuem causas às influências ambientais, como vínculos frágeis e associação a pares infratores. E, por último, quando os comportamentos antissociais se iniciam tardiamente, ao final da adolescência e início da vida adulta, as causas seriam os déficits individuais (baixa capacidade cognitiva e problemas internalizantes), que não se manifestaram nos estágios anteriores devido ao apoio familiar e aos ambientes protetores.

Per-Olof Wikström (2005) propôs a Teoria da Ação Situacional (Situational Action Theory [SAT]) que tem como objetivo explicar os mecanismos causais que levam indivíduos a violarem as regras morais estabelecidas pelas leis. Diferente da maioria das teorias, a SAT foca nos atos criminosos (ação) e não no indivíduo que pratica o ato criminoso. Em certa medida, é necessário identificar o que leva o indivíduo a praticar o ato, mas o que Wikström propõe é identificar os processos que conectam o indivíduo ao ambiente, de modo a produzir a ação criminosa. Dessa forma, o autor estabelece que a ação do indivíduo é consequência de como ele percebe suas opções de agir e, assim, faz suas escolhas com base em particularidades do ambiente. As opções de ação e o processo de escolha são os mecanismos situacionais que conectam o indivíduo e seu ambiente à ação. Para a SAT, os valores morais e o autocontrole (agir de acordo com os próprios valores) desempenham um papel central no processo de escolha, e as motivações (desejos, ambições, tentações) vão determinar o tipo de crime que o indivíduo se envolverá. A teoria ainda estabelece que alguns indivíduos exercem melhor autocontrole que outros, resistindo às tentações e, portanto, violando as regras/leis com menos frequência. A origem do autocontrole residiria nas capacidades executivas, desenvolvidas pela interação entre fatores biológicos e experiências de vida.

Uma vez sintetizados os aspectos mais salientes de cada teoria, notam-se pontos convergentes e divergentes entre elas. Um aspecto importante que se destaca refere-se à variedade de fatores que cada teoria identifica como relevante, coincidindo, algumas vezes, mas muitas vezes não. A esse respeito surge o questionamento se as teorias não deveriam 
apresentar maior grau de convergência entre si, dado que todas se desenvolveram amparadas por dados de pesquisas empíricas de amostras populacionais. A resposta é não. As diferenças metodológicas entre os estudos - instrumentos e variáveis mensuradas de forma distintas - e as especificidades socioculturais do contexto em que os estudos foram realizados proporcionaram a diversidade teórica.

Outro ponto que se pode observar é que a maioria das teorias descritas nesse tópico trata, na verdade, da elaboração e/ou da integração de outras teorias como do Aprendizado Social (Bandura, 1977; Burgess \& Akers, 1966; Akers, Krohn, Lanza-Kaduce \& Radosevich, 1979), da Associação Diferencial (Sutherland, 1947), do Controle (Hirschi, 1969), da Escolha Racional, da Rotina (Cohen \& Felson, 1979) da Rotulação (Knutsson, 1977) ou da Teoria Geral do Crime (Gottfredson, M. R., \& Hirschi, 1990). Essa constatação ressalta a força dos construtos trazidos por essas teorias, digamos "clássicas", para a explicação da conduta delituosa. Conceitos como vínculo, controle informal e aprendizado social ressurgem na maioria das teorias descritas, o que nos permite cogitar a existência de fatores explicativos universais e outros específicos a cada realidade sociocultural.

Por fim destaca-se que, de um lado, há teorias bastante concisas - como a de Lahey e Waldman - que fornecem alguns poucos fatores-chave para a modificação do comportamento, o que pode facilitar a elaboração e a implementação de programas de intervenção psicossocial; essas, porém, ignoram fatores socioculturais sabidamente importantes. De outro lado, há teorias bastante abrangentes - como a de Le Blanc - que apresentam uma complexa teia de influências recíprocas entre variáveis que contemplam múltiplos domínios, mas que são impraticáveis no contexto da prática profissional pela restrição de tempo e de recursos. A esse respeito, os critérios de relevância dos fatores, propostos por Luthar (2006), são fundamentais para guiar a aplicação das teorias.

Considerando esses três pontos - os aspectos universais; os fatores contextuais, sociais e culturais específicos de cada localidade; e a necessidade da relevância tanto teórica quanto prática da teoria - torna-se evidente a carência de uma referência teórica e prática que possa ser empregada para guiar a proposição de políticas públicas e as práticas do judiciário, no Brasil. A despeito das generalizações que se podem fazer das teorias criminológicas desenvolvidas em outros países, o desenvolvimento da criminologia brasileira depende necessariamente de um processo de aproximação e de conhecimento da própria população brasileira, por meio de levantamento e de monitoramento periódico de variáveis como as crenças, os valores, as atitudes e os comportamentos especialmente da população jovem. 
80 | Marco teórico: a Psicopatologia do Desenvolvimento 


\section{CAPÍTULO 3}

\section{AVALIAÇÃO DE RISCO DE VIOLÊNCIA}

No âmbito internacional, as pesquisas sobre fatores de risco e de proteção para a conduta delituosa e violenta vêm sendo utilizados para a formulação de protocolos de avaliação, envolvendo instrumentos estruturados, alguns dos quais amplamente empregados no âmbito do Sistema de Justiça, com vistas às tomadas de decisão quanto à aplicação de medidas judiciais, à proposição de programas institucionais e à elaboração de planos de intervenção personalizados. Tem-se protocolos específicos, alguns para a realização de avaliação de risco de reincidência, de risco de quebra de medidas judiciais e risco de conduta violenta. Há um corpo substancial de pesquisas que mostram que esses métodos estruturados de avaliação de risco produzem estimativas mais precisas e de melhor qualidade que métodos não estruturados (Borum, 2001; Rice, 2005). A avaliação de risco baseada em evidências, servindo-se dos instrumentos formulados com base nos fatores de risco e de proteção conhecidos, tem sido reconhecida como uma das boas práticas incorporadas pelo Sistema de Justiça de muitos países, ajudando na tomada de decisões mais racionais e com impacto na redução efetiva da reincidência geral e da violência. Por esses motivos a avaliação de risco tem sido cada vez mais requisitada e implementada em instituições que necessitam tomar decisões no contexto forense (Casey, Warren \& Elek 2011; Desmarais, Johnson \& Singh, 2018).

\subsection{Razões para o uso da Avaliação de Risco de Violência}

O termo avaliação de risco de violência (ARV) se refere a uma estimativa de risco, atuarial (probabilística) ou descritiva (indicativa de um nível como, por exemplo, baixo, moderado ou alto), de um indivíduo, em um futuro próximo, envolver-se em uma situação violenta - agir de modo violento. Em um sentido mais amplo, o termo também pode se referir a todo o processo que envolve uma avaliação de risco em contexto forense: 1. Atribuir um nível de risco a um indivíduo; 2. Identificar os principais fatores que contribuem para o risco; 3. Identificar estratégias para diminuir ou manejar o risco; 4. Comunicar as informações anteriores aos tomadores de decisão (Mills, Kroner \& Morgan, 2012, p. 16-17). A avaliação de risco também pode ser aplicada para estimar o nível de risco não de pessoas, mas de 
contextos, pela qual se afere o risco de violência em determinada situação, levando-se em conta fatores que têm sido estudados no campo da Criminologia Ambiental (Cullen \& Kulig, 2018; Engelhardt \& Bartholow, 2013; Frost \& Nowak, 2014; Guedes, Moreira, Teixeira \& Cardoso, 2018; Welsh, Bader, \& Evans, 2013).

A ARV possui duas principais funções: proteger a sociedade e proteger o indivíduo (Lipsey, Howell, Kelly, Chapman \& Carver, 2010). A primeira consiste em evitar que a violência cause danos humanos e materiais, identificando situações de alto risco e promovendo ações que possam reduzir ou anular esse risco. Nesse caso, a avaliação de risco é realizada em termos contextuais, podendo levar em consideração aspectos urbanos e ambientais (como o fato de um bairro ter pouca iluminação), situacionais (como um dia de jogo de futebol entre equipes rivais) ou relacionais (como um casal com histórico de relacionamento conflituoso). Em dias de festividade religiosa, por exemplo, as autoridades de vários países se colocam em alerta para ataques terroristas por ser um período em que aumentam os riscos desse tipo de violência.

Nesse plano, há também as avaliações de risco realizadas em contexto judiciário/forense, no qual um infrator passa por uma avaliação para que sejam tomadas decisões quanto à medida judicial a que deve ser submetido ou, no caso de infratores em regime de privação de liberdade, decisões relativas à questão de quando poderá ser posto em liberdade novamente. Essas seriam a ARV a nível individual. Nesses casos, indivíduos avaliados como apresentando risco elevado para cometer atos violentos devem passar por tratamentos que diminuam os riscos, de modo a serem reintegrados e viverem livremente em sociedade.

A segunda função da ARV consiste em evitar que o próprio indivíduo agressor sofra as consequências legais, relacionais e desenvolvimentais de praticar um ato violento, por meio de práticas de prevenção primária e secundária junto a indivíduos considerados sob risco elevado. Em termos legais, o infrator poderá sofrer sanções embasadas unicamente na gravidade do ato, desconsiderando suas características e necessidades individuais, o que pode produzir efeitos adversos para o seu desenvolvimento, para além dos conhecidos efeitos negativos inerente à rotulação, que aumentam a probabilidade de voltar a infracionar (Bernburg, Krohn \& Rivera, 2006; Farrington, 1977; Farrington \& Murray, 2014; Komatsu \& Bazon, 2016). Em termos relacionais, um ato violento pode fragilizar ou mesmo romper as relações do infrator com figuras pró-sociais, como quando o ato ocorre no âmbito familiar (Acero, 2016). E em termos desenvolvimentais, uma importante consequência de praticar uma violência são as alterações neuroquímicas e neuroestruturais que ocorrem no sistema nervoso 
do próprio agressor, que facilitam a naturalização da conduta violenta, ou seja, contribuem para aumentar a probabilidade de reincidência em ações violentas. Ademais, indivíduos que se implicam em atos violentos acabam se expondo a maiores riscos, como sugere o estudo de Paul e Piquero (2008) que encontrou que infratores persistentes morrem mais frequentemente por causas não naturais, como acidentes de trânsito, homicídios e suicídios, que infratores esporádicos, em contexto estadunidense, e o estudo de Lindberg, Miettunen, Heiskala e Kaltiala-Heino (2017) que verificou que a incidência de morte prematura é duas vezes maior em infratores violentos, se comparados a infratores não violentos, em contexto finlandês. Dessa forma, a avaliação de risco apresenta-se como um procedimento que pode ajudar a identificar potenciais problemas que podem ser evitados, salvaguardando indivíduos e sociedade.

Embora a ARV possa e deva ser, preferencialmente, baseada em instrumentos estruturados, baseados no amplo e consistente conhecimento já existente sobre os principais fatores de risco e de proteção, há muito que se avançar no âmbito profissional. À título de exemplo, destaca-se o trabalho de Tolman e Mullendore (2003), no qual fizeram um levantamento junto a psicólogos clínicos no estado de Michigan e encontraram que 9\% consideram-se psicólogos forenses, embora 53\% deles já tivessem conduzido uma avaliação de risco, cujo resultado foi utilizado em procedimentos legais; e $45 \%$ já tivessem feito uma avaliação com o propósito de subsidiar decisões concernindo sentenças criminais. Em todos os casos, a maioria referiu não ter lançado mão de instrumentos específicos de avaliação de risco. Adicionalmente, Lally (2003) fornece evidências de que a preferência por instrumentos não específicos ocorre mesmo entre profissionais com especialização na área forense. Não obstante os grandes avanços teóricos e metodológicos no contexto da avaliação de risco, muitos profissionais seguem atuando de forma "intuitiva", como antigamente. Tal constatação é preocupante na medida em que a avaliação de risco traz impactos importantes para a sociedade e para a o indivíduo avaliado.

É verdade que a ARV tem sido pauta de constantes debates. Embora os estudos mostrem que as ferramentas estruturadas de avaliação de risco possuem melhor acurácia que a avaliação clínica de especialistas (Borum, 2001; Rice, 2005), há críticas em relação ao efeito estigmatizador que esse tipo de avaliação pode produzir e também dúvidas quanto à capacidade dessas ferramentas de considerar a plasticidade do desenvolvimento dos jovens e à acurácia dos instrumentos (Campbell, 2003; Monahan \& Skeem, 2016). Essas críticas são legítimas e relevantes, mas a resposta a elas é bastante simples: sem o uso de procedimentos estruturados e sistemáticos para a avaliação de risco esses pontos críticos continuam existindo 
e, talvez, de forma ainda mais aguda. Por exemplo, no estudo de Hilton e Simmons (2001), em contexto forense, foi verificado que a opinião clínica do profissional responsável pelos casos era o que mais influenciava na decisão dos tribunais em deter prisioneiros em segurança máxima ou transferi-los. Um aspecto curioso desse estudo é que a opinião clínica dos profissionais responsáveis não se correlacionou com os escores do Violence Risk Appraisal Guide (VRAG) - instrumento de avaliação de risco com base em estudos empíricos, que estava disponível a esses profissionais - mas esteve correlacionada a outras variáveis aparentemente irrelevantes para a questão, como o uso de medicamento psicotrópico e a atratividade física do paciente. Assim, fica claro que abandonar o uso de procedimentos estruturados de ARV não sanam suas limitações. Como observado por Large e Nielssen (2017), as formas de avaliação não estruturadas carecem de transparência, são muito vulneráveis a vieses cognitivos e depositam toda sua credibilidade na experiência e expertise do clínico.

Posto isso, pode-se dizer que toda autoridade judicial ou técnico forense realiza, em alguma medida, uma "avaliação de risco" para tomar suas decisões. A diferença entre as avaliações consiste no procedimento e nos materiais empregados pelos profissionais, podendo variar da mera intuição ou do uso de técnicas e instrumentos pouco robustos ao uso das ferramentas e protocolos mais atualizados e confluentes com as evidências empíricas de estudos científicos da área. O uso da ARV estruturada, com base em instrumentos, favorece ao beneficiário por tornar o processo de avaliação mais transparente, de modo que as decisões em âmbito institucional passam a ter maior legitimidade na medida em que suas justificativas são mais claras e racionais. Do ponto de vista do beneficiário, a ARV pode ajudá-lo a identificar aspectos deficitários que, se desenvolvidos, podem promover mudanças positivas significativas em sua vida social. Nesse sentido, a ARV deve ser entendida como uma ferramenta que busca melhorar as condições das pessoas, seja com a possibilidade de “abrandar” a pena/medida, conceder benefícios/progressões em âmbito institucional ou ajudálas a se compreender melhor. Em sentido oposto, a ARV não deve ser utilizada para rotular indivíduos (enfatizar aspectos estáticos/imutáveis), nem para aumentar ou endurecer a pena/medida mais do que já está previsto em lei. 


\subsection{A evolução dos procedimentos de avaliação de risco de violência}

A ideia de "identificar o risco que certos indivíduos representam à sociedade" não é nova. Embora a finalidade deste tipo de avaliação em contexto forense tenha sido estabelecida há décadas, o conceito de "risco de violência" foi sofrendo alterações. Inicialmente, as bases conceituais nesse campo assumiam uma visão dicotômica, pela qual os indivíduos avaliados podiam ou não apresentar "risco de violência" (Borum, 2000). A rigor, nessa ocasião, o conceito chave era o de "periculosidade", que implicava determinar se a pessoa possuía potencial violento ou não. Tratava-se, portanto, de uma concepção estática e que admitia pouca margem para mudanças. Conforme apontado por Andrés-Pueyo e Redondo-Illescas (2007), a capacidade preditiva da periculosidade era diminuta.

Hoje, as teorias assumem o "risco de violência" como um construto contextual (dependente das situações e das circunstâncias), dinâmico (sujeito a mudanças) e contínuo (variando em um contínuo de probabilidade). O desenvolvimento deste campo forense nas últimas décadas ocorreu por três motivos principais: 1) melhor conhecimento da natureza e dos processos que produzem a violência; 2) mudança do paradigma "avaliação da periculosidade" para "avaliação de risco"; 3) desenvolvimento de protocolos e instrumentos para avaliação de risco. De forma suscinta, a evolução dos instrumentos de ARV passaram por quatro fases de grandes transformações (Desmarais \& Singh, 2013).

A primeira geração (aproximadamente até os anos 1970) consistiu na avaliação profissional não estruturada (UPJ; Unstructured Professional Judgement). A tarefa do clínico especialista era emitir um parecer sobre a periculosidade do indivíduo, e fazia-se isso com base, principalmente, na experiência e expertise próprias. Esse procedimento passou a ser alvo de muitas críticas por sua falta de transparência e de confiabilidade. $\mathrm{O}$ inusitado título do trabalho de Ennis e Litwack (1973) resume essa fase da avaliação de risco: "Psychiatry and the Presumption of Expertise: Flipping Coins in the Courtroom". Na obra, os autores detalham como esse tipo de avaliação era tão acurada quanto a sorte / o acaso.

Com o acúmulo de conhecimento específico produzido pelo número cada vez maior de estudos longitudinais, com amostras populacionais, a segunda geração de procedimentos atinentes à avaliação de risco (anos 1980) incorporou as evidências empíricas e técnicas atuariais em um procedimento mais transparente, objetivo e acurado que a UPJ (Pfohl, S., \& Monahan, 1983). No entanto, os fatores incorporados pela segunda geração eram basicamente todos estáticos, não suscetíveis a ações de intervenção e sem expectativa de mudanças ao longo do tempo. Dessa forma, esse tipo de avaliação pouco ajudava na proposição de 
programas preventivos, além de não serem capazes de explicar satisfatoriamente a escalada ou a desistência de trajetórias violentas, por vezes verificada.

O avanço e a popularização dos computadores permitiram analisar a grande quantidade de informações provenientes dos diversos estudos longitudinais que estavam em curso e a empregar cada vez mais técnicas atuariais para estimar o risco de violência com base em algoritmos que combinavam o efeito das diferentes variáveis. Assim, a terceira geração de procedimento de avaliação de risco (anos 1990) também passou a considerar fatores de risco dinâmicos e necessidades criminogênicas (Bonta, Law \& Hanson, 1998). Isso representou um grande avanço, embora uma das deficiências dessa geração tenha sido a falta de planos de intervenção integrados que acompanhassem a ARV.

A quarta geração (anos 2000) caracterizou-se por ir além da aferição do risco e focar no tratamento e no gerenciamento dos fatores relacionados à violência, dentro do processo de avaliação (Andrés-Pueyo, Arbachi-Lucioni, Redondo, 2018; Seifert, 2012). Nesse sentido, os protocolos passaram a indicar, junto com o risco, os programas para reabilitação/tratamento e as melhores medidas para gerenciar e diminuir o risco atribuído. Atualmente, é possível que se esteja caminhado na direção de uma quinta geração de ARV, em virtude da incorporação cada vez mais crescente dos fatores de proteção, que explicariam o fato empírico de que muitos adolescentes sob alto risco não se comportam de forma violenta, e do uso de big datas e de ferramentas de machine learning.

Em síntese, antes os clínicos tinham a tarefa de determinar se um indivíduo era perigoso ou não. Agora, o desafio é determinar a natureza do risco, o grau de exposição aos riscos, o contexto em que o comportamento pode emergir e balancear com os efeitos neutralizadores dos fatores de proteção, de forma a visualizar os caminhos que permitem gerenciar o risco (Borum, 2000; Andrés-Pueyo \& Redondo-Illescas, 2007).

\subsection{Instrumentos de avaliação de risco de violência}

Os protocolos estruturados de ARV atuais podem ser classificados em duas categorias em relação à abordagem de avaliação adotada: Avaliação Atuarial e Avaliação Profissional Estruturada (SPJ; Structured Professional Judgement). A abordagem atuarial consiste em um procedimento mecânico em que os fatores de risco, em geral históricos, são computados e cruzados com uma tabela de referência que estima o risco apresentado por um indivíduo de voltar a agir violentamente, dentro de um determinado período de tempo (Desmarais \& Singh, 2013). Dessa forma, se o instrumento estima que o indivíduo possui $60 \%$ de chance de voltar 
a infracionar significa que, na amostra do estudo normativo, 60\% dos indivíduos que obtiveram pontuação igual ou superior no instrumento infracionaram. Esse método tem a vantagem de ser objetivo (não envolve julgamento humano), acurado (mais que a avaliação clínica não estruturada), transparente (os itens utilizados para informar o risco estão explícitos no instrumento) e rápido (em geral as informações estão disponíveis em registros oficiais como, por exemplo, o histórico criminal ou o histórico escolar) (Desmarais \& Singh, 2013).

Em contraste à abordagem atuarial, a SPJ consiste em uma avaliação humana, porém estruturada, de fatores que se associam teórica e empiricamente à conduta delituosa e/ou violenta. Na SPJ, cada fator estabelecido pelo protocolo deve ser pensado em termos da importância que ele tem para cada indivíduo em específico. Por isso tem a vantagem de prover informações úteis para o manejo do risco e também para a intervenção. A SPJ difere dos métodos atuariais na medida em que o próprio profissional avaliador, e não um algoritmo, quem decide se o fator de risco ou de proteção consiste em uma influência relevante na vida do indivíduo. E difere da UPJ na medida em que há um protocolo com as variáveis apropriadamente operacionalizadas e embasado por investigações científicas que guia a avaliação do profissional.

Há centenas de instrumentos de avaliação de risco disponíveis e selecionar o mais apropriado não é uma tarefa trivial e depende de cada situação. A Tabela 3.1 apresenta a descrição dos instrumentos mais utilizados no mundo, segundo a revisão de Singh, Grann e Fazel (2011). Os cinco primeiros (LSI-R, PCL-R, SORAG, Static-99 e VRAG) pertencem à categoria de instrumentos atuariais, enquanto que os seis seguintes (HCR-20, SVR-20, SARA, SAVRY, SAPROF e RisCanvi) se enquadram na categoria de SPJ. Esses dois últimos instrumentos não apareceram na revisão original, mas foram adicionados à tabela por possuírem relevância teórica e por representarem o que poderia ser chamado de quinta geração dos instrumentos de avaliação de risco.

O SAPROF (de Vries Robbé, Geers, Stapel, Hilterman \& Vogel, 2007) por ser o único instrumento de ARV que foca exclusivamente nos fatores de proteção. $O$ instrumento foi construído para balancear os fatores de risco que as demais ferramentas avaliam, em virtude do fato de a maioria dos instrumentos de ARV não considerar os fatores protetores ou considerarem apenas alguns deles. O RisCanvi não poderia aparecer na revisão por ser de uso exclusivo do governo da Catalunha, embora haja um conjunto de publicações a respeito que mostram inovações importantes em relação a outros protocolos (Andrés-Pueyo Andrés-Pueyo et al., 2018; Capdevila et al., 2015). Este instrumento possui a versão de rastreamento (RisCanvi-S) com 10 itens, que é aplicada a todos os prisioneiros da Catalunha, e a versão 
completa (RisCanvi-C) com 43 itens, aplicada nos casos em que o RisCanvi-S sinaliza risco alto ou em outras situações especiais como nos casos de prisioneiros detidos por atos violentos. A versão de rastreamento torna o funcionamento das instituições prisionais mais dinâmico, dispensando da avaliação completa aqueles que não aparentam (com base em evidências do processo de rastreamento) necessitá-la. O protocolo também é reaplicado a cada seis meses, monitorando as mudanças ao longo do tempo e acumulando dados que retroalimentam o protocolo para seu próprio aperfeiçoamento. Um recurso importante do RisCanvi refere-se ao algoritmo que combina os itens para diferenciar a natureza de risco de violência mais significativa para um determinado indivíduo, podendo ser essa de quatro tipos: violência no contexto institucional/prisional, contra a equipe técnica ou contra outros presos; contra a si próprio (suicídio); de reincidência (quando ganham a liberdade); de quebra de medida (quando recebem benefícios). Cada uma dessas categorias de risco parece ter etiologia distinta (estando associada a conjuntos diferenciados de fatores), o que justifica que os itens tenham pesos diferentes para a predição de cada uma delas. Apesar do algoritmo por trás do protocolo, o avaliador profissional tem autonomia para validar ou não o resultado, podendo discordar do risco estimado (baixo, moderado ou alto) desde que justifique o porquê, o que faz com que possa ser caracterizando como um instrumento de SPJ. O RisCanvi também prevê um conjunto de programas de intervenção e de gerenciamento de risco específicos para cada categoria de risco. 
Tabela 3.1

Síntese dos principais instrumentos de avaliação de risco

\begin{tabular}{|c|c|c|c|c|c|}
\hline Instrumento (Autores) & Itens & Descrição & Pontuação & Predição & Domínios \\
\hline $\begin{array}{l}\text { Level of Service } \\
\text { Inventory - Revised (LSI- } \\
\text { R; Andrews \& Bonta, } \\
\text { 1995) }\end{array}$ & 54 & $\begin{array}{l}\text { Desenvolvido para predizer risco de } \\
\text { reincidência geral em adultos e auxiliar } \\
\text { profissionais a tomarem decisões em } \\
\text { relação a tratamento e monitoramento. }\end{array}$ & $\begin{array}{l}0=\text { item ausente } \\
1=\text { item presente }\end{array}$ & $\begin{array}{l}\text { Delinquên } \\
\text { cia Geral }\end{array}$ & $\begin{array}{l}\text { (1) Histórico criminal } \\
\text { (2) Lazer/Ócio } \\
\text { (3) Educação/Emprego } \\
\text { (4) Pares } \\
\text { (5) Finanças } \\
\text { (6) Problema com álcool/drogas } \\
\text { (7) Família } \\
\text { (8) Emocional/Pessoal } \\
\text { (9) Acomodação } \\
\text { (10) Atitudes }\end{array}$ \\
\hline $\begin{array}{l}\text { Psychopathy Checklist- } \\
\text { Revised (PCL-R; Hare, } \\
\text { 1991, 2003) }\end{array}$ & 20 & $\begin{array}{l}\text { Desenvolvido para diagnosticar psicopatia } \\
\text { conforme definido por } \\
\text { Cleckley (1941) }\end{array}$ & $\begin{array}{l}0=\text { item não se aplica } \\
1=\text { item se aplica em alguma } \\
\text { medida } \\
2=\text { item se aplica }\end{array}$ & $\mathrm{n} / \mathrm{a}$ & $\begin{array}{l}\text { (1) egoísmo, falta de empatia e uso dos } \\
\text { outros sem remorso } \\
\text { (2) Estílo de vida antissocial e instável } \\
\text { crônico }\end{array}$ \\
\hline $\begin{array}{l}\text { Sex Offender Risk } \\
\text { Appraisal Guide } \\
\text { (SORAG; Quinsey, } \\
\text { Harris, Rice \& Cormier, } \\
\text { 1998, 2006) }\end{array}$ & 14 & $\begin{array}{l}\text { Desenvolvido para avaliar o risco de } \\
\text { reincidência violenta (incluindo violência } \\
\text { sexual) especialmente em infratores } \\
\text { sexuais }\end{array}$ & Pontuação varia entre os itens & $\begin{array}{l}\text { Violência } \\
\text { geral }\end{array}$ & $\mathrm{n} / \mathrm{a}$ \\
\hline $\begin{array}{l}\text { Static-99 (Hanson \& } \\
\text { Thornton, 1999; Harris, } \\
\text { Phenix, Hanson \& } \\
\text { Thornton, 2003) }\end{array}$ & 10 & $\begin{array}{l}\text { Desenvolvido para predizer o risco de } \\
\text { reincidência de delitos sexuais em adultos } \\
\text { infratores sexuais }\end{array}$ & Pontuação varia entre os itens & $\begin{array}{l}\text { Violência } \\
\text { sexual }\end{array}$ & $\mathrm{n} / \mathrm{a}$ \\
\hline $\begin{array}{l}\text { Violence Risk Appraisal } \\
\text { Guide (VRAG; Quinsey, } \\
\text { Harris, Rice \& Cormier, } \\
\text { 1998, 2006) }\end{array}$ & 12 & $\begin{array}{l}\text { Desenvolvido para predizer o risco de } \\
\text { reincidência de delitos violentos em } \\
\text { população psiquiátrica }\end{array}$ & Pontuação varia entre os itens & $\begin{array}{l}\text { Violência } \\
\text { geral }\end{array}$ & $\mathrm{n} / \mathrm{a}$ \\
\hline $\begin{array}{l}\text { Historical Clinical Risk } \\
\text { Management-20 (HCR- } \\
\text { 20; Webster, Eaves, } \\
\text { Douglas \& Wintrup, } \\
\text { 1995; Webster, Douglas, }\end{array}$ & 20 & $\begin{array}{l}\text { Desenvolvido para avaliar o risco de } \\
\text { violência em âmbito forense }\end{array}$ & $\begin{array}{l}0=\text { item ausente } \\
1=\text { item possivelmente presente } \\
2=\text { item definitivamente presente }\end{array}$ & $\begin{array}{l}\text { Violência } \\
\text { geral }\end{array}$ & $\begin{array}{l}\text { (1) Fatores de risco históricos } \\
\text { (2) Fatores de risco clínicos } \\
\text { (3) Fatores de gerenciamento do risco }\end{array}$ \\
\hline
\end{tabular}

Eaves \& Hart, 1997) 


\begin{tabular}{|c|c|c|c|c|c|}
\hline $\begin{array}{l}\text { Sexual Violence Risk-20 } \\
\text { (SVR-20; Boer, Hart, } \\
\text { Kropp \& Webster, 1997) }\end{array}$ & 20 & $\begin{array}{l}\text { Desenvolvido para avaliar o risco de } \\
\text { reincidência violenta (incluindo violência } \\
\text { sexual) especialmente em infratores } \\
\text { sexuais }\end{array}$ & $\begin{array}{l}0=\text { item ausente } \\
1=\text { item possivelmente presente } \\
2=\text { item definitivamente presente }\end{array}$ & $\begin{array}{l}\text { Violência } \\
\text { sexual }\end{array}$ & $\begin{array}{l}\text { (1) Fatores de risco históricos } \\
\text { (2) Fatores de risco sociais/contextuais } \\
\text { (3) Fatores de risco individuais/clínicos } \\
\text { (4) Fatores protetores }\end{array}$ \\
\hline $\begin{array}{l}\text { Spousal Assault Risk } \\
\text { Assessment (SARA; } \\
\text { Kropp \& Hart, 1994, } \\
\text { 1995, 1999) }\end{array}$ & 20 & $\begin{array}{l}\text { Desenvolvido para predizer o risco de } \\
\text { violência em homens detidos por } \\
\text { violência conjugal }\end{array}$ & $\begin{array}{l}0=\text { item ausente } \\
1=\text { item possivelmente presente } \\
2=\text { item definitivamente presente }\end{array}$ & $\begin{array}{l}\text { Violência } \\
\text { geral }\end{array}$ & $\begin{array}{l}\text { (1) Violência geral } \\
\text { (2) Violência conjugal }\end{array}$ \\
\hline $\begin{array}{l}\text { Structured Assessment of } \\
\text { Violence Risk in Youth } \\
\text { (SAVRY; Borum, Bartel, } \\
\text { \& Forth, 2002, 2003, } \\
\text { 2006) }\end{array}$ & 24 & $\begin{array}{l}\text { Desenvolvido para avaliar o risco de } \\
\text { violência em adolescentes }\end{array}$ & $\begin{array}{l}0=\text { item representa um baixo risco } \\
\text { de reincidência } \\
1=\text { item represente um risco } \\
\text { moderado de reinciência } \\
2=\text { item representa um risco alto de } \\
\text { reincidência }\end{array}$ & $\begin{array}{l}\text { Violência } \\
\text { geral }\end{array}$ & $\begin{array}{l}\text { (1) Fatores de risco históricos } \\
\text { (2) Fatores de risco sociais/contextuais } \\
\text { (3) Fatores de risco individuais/clínicos } \\
\text { (4) Fatores protetores }\end{array}$ \\
\hline $\begin{array}{l}\text { Structured Assessment of } \\
\text { Protective Factors for } \\
\text { Violence Risk (SAPROF; } \\
\text { de Vries Robbé, Geers, } \\
\text { Stapel, Hilterman \& } \\
\text { Vogel, 2007) }\end{array}$ & 17 & $\begin{array}{l}\text { Desenvolvido para balancear os fatores de } \\
\text { risco (avaliados por outras ferramentas) } \\
\text { com os fatores de proteção }\end{array}$ & $\begin{array}{l}0=\text { item não se aplica } \\
1=\text { item provavelmente se aplica ou } \\
\text { se aplica parcialmente } \\
2=\text { item definitivamente se aplica }\end{array}$ & $\begin{array}{l}\text { Violência } \\
\text { geral }\end{array}$ & $\begin{array}{l}\text { (1) Fatores internos } \\
\text { (2) Fatores motivacionais } \\
\text { (3) Fatores externos }\end{array}$ \\
\hline $\begin{array}{l}\text { Riscanvi (Departamento } \\
\text { de Justicia de la } \\
\text { Generalitat de Cataluña, } \\
\text { 2009) }\end{array}$ & 43 & $\begin{array}{l}\text { Desenvolvido para avaliar o risco de } \\
\text { condutas violentas e quebras de medidas } \\
\text { em contexto penitenciário, reincidência } \\
\text { violenta e violência autodirigida }\end{array}$ & $\begin{array}{l}0=\text { item ausente } \\
1=\text { item presente } \\
?=\text { informação não disponível }\end{array}$ & $\begin{array}{l}\text { Violência, } \\
\text { Violência } \\
\text { autodirigi } \\
\text { da, } \\
\text { Quebra de } \\
\text { medida }\end{array}$ & $\begin{array}{l}\text { (1) Fatores criminais/penitenciários } \\
\text { (2) Fatores pessoais/socio familiares } \\
\text { (3) Fatores clínicos/personalidade }\end{array}$ \\
\hline
\end{tabular}

Fonte: Singh, Grann \& Fazel (2011). Acrescentado as informações sobre o SAPROF e o Riscanvi. 
Singh, Grann e Fazel (2011) também realizaram uma metanálise de 68 estudos que verificavam a validade preditiva de cada instrumento em relação a condutas violentas. A Tabela 3.2 mostra o poder de predição de cada ferramenta em duas condições ligeiramente diferentes. Os dados da esquerda comparam indivíduos avaliados como "risco alto" com indivíduos avaliados como "risco baixo" ou "risco moderado". Os dados da direita são referentes à comparação entre indivíduos avaliados como "risco alto" ou "risco moderado" com indivíduos avaliados como "risco baixo". Os resultados mostram que os instrumentos possuem performance bastante discrepante. Como esperado, instrumentos específicos para avaliar o risco de violência, como o SAVRY, o VRAG e o SARA, tiveram melhor desempenho que o LSI-R, desenvolvido para avaliar o risco de reincidência em delitos de forma geral, e que o PCL-R. Curiosamente, instrumentos não específicos como o PCL-R e o MMPI são os mais utilizados por psicólogos em contexto forense para a avaliação de risco (Nicholson \& Norwood, 2000; Tolman \& Mullendore, 2003). Em relação ao aspecto atuarial ou de SPJ, os dados não permitiram tirar conclusões sobre uma maior ou melhor performance de um sobre o outro.

Tabela 3.2

Validade preditiva dos principais instrumentos de avaliação de risco

\begin{tabular}{lccccccccccc}
\hline \multicolumn{3}{c}{ Risco alto vs. Risco baixo/moderado } & & \multicolumn{4}{c}{ Risco alto/moderado vs. Risco baixo } \\
Instrumento & $\mathbf{n}$ & $\mathbf{k}$ & OR & I.C. 95\% & & Instrumento & $\mathbf{n}$ & $\mathbf{k}$ & OR & I.C. 95\% \\
\hline SAVRY & 1026 & 9 & 6,9 & {$[4,93-9,73]$} & & SARA & 465 & 3 & 7,9 & {$[3,12-19,8]$} \\
VRAG & 2703 & 12 & 3,8 & {$[2,85-5,16]$} & & SAVRY & 1026 & 9 & 6,4 & {$[4,4-9,32]$} \\
HCR-20 & 1374 & 9 & 3,5 & {$[2,62-4,62]$} & & SORAG & 1599 & 6 & 5,5 & {$[4,09-7,5]$} \\
SARA & 2305 & 4 & 3,4 & {$[2,72-4,29]$} & & VRAG & 2602 & 11 & 5,2 & {$[3,61-7,53]$} \\
Static-99 & 8555 & 14 & 3,1 & {$[1,94-5,02]$} & & HCR-20 & 1320 & 8 & 4,9 & {$[3,65-6,56]$} \\
SORAG & 1637 & 7 & 2,5 & {$[2,15-2,96]$} & & Static-99 & 8097 & 10 & 3,0 & {$[2,38-3,66]$} \\
PCL-R & 3854 & 20 & 2,1 & {$[1,14-3,81]$} & & PCL-R & 3854 & 20 & 2,1 & {$[1,14-3,81]$} \\
LSI-R & 4005 & 8 & 1,8 & {$[0,96-3,22]$} & & LSI-R & 4005 & 8 & 1,3 & {$[0,77-2,06]$} \\
SVR-20 & 521 & 5 & 1,6 & {$[0,36-6,84]$} & & SVR-20 & 268 & 3 & 1,2 & {$[0,18-8,32]$} \\
\hline
\end{tabular}

$\mathrm{n}=$ tamanho da amostra; $\mathrm{k}=$ número de amostras; OR = razão de chances (Odds Ratio); I.C. = limites inferiores e superiores do intervalo de confiança de 95\% para o OR. (Fonte: Singh, Grann \& Fazel, 2011)

Mediante a possibilidade de usar algum dos instrumentos mencionados, recomenda-se algumas precauções na seleção do mesmo, a depender do propósito do avaliador. Por exemplo, apesar do SAVRY ter performado melhor que o SORAG nas duas condições, a escolha do SORAG faz mais sentido se o interesse da avaliação consiste em predizer delitos 
sexuais. Nesse sentido, Fazel e Wolf (2018) recomendam dez questões a serem consideradas na escolha de um instrumento de avaliação de risco, cinco referentes à validade externa e cinco à validade interna:

1. A ferramenta foi validada externamente? Instrumentos costumam ter melhor desempenho na amostra em que foram criados.

2. A validação foi realizada na população de interesse? Um avaliador interessado em avaliar mulheres não deve selecionar um instrumento que foi validado em amostra masculina.

3. O método da validação é sólido? O protocolo de validação deve seguir o mesmo protocolo do estudo original, o número de participantes deve ser superior a 100 e não deve possuir vieses de amostragem.

4. A validação reporta as informações essenciais? Deve-se dispor de informações sobre a capacidade discriminante e da precisão do instrumento.

5. O instrumento é útil, viável e aceitável? A ferramenta deve prover informações úteis, definir claramente as variáveis e os indicadores, ser objetiva e relativamente simples de completar.

6. O instrumento segue um protocolo? Sem um protocolo a ferramenta pode ter ótimos índices de validade e precisão, mas não funcionar na prática.

7. Como os indicadores foram selecionados para compor o instrumento? Quanto mais variáveis utilizadas para chegar no instrumento final, maior a chance de ter alguma variável que foi selecionada por acaso estatístico.

8. Como as variáveis são ponderadas no modelo? A maioria dos modelos atribuem o mesmo peso a todas as variáveis, assumindo que elas possuem o mesmo grau de associação com a variável desfecho. Isso requer que as variáveis sejam independentes umas das outras. Por exemplo, se o modelo incluí as variáveis "maus-tratos infantis" e "prática parental inadequada” parte dos pesos dessas duas variáveis está sendo contabilizada mais de uma vez, pois elas não são independentes.

9. Como os parâmetros foram selecionados? Por exemplo, se a escolha do tempo estimado para predizer o risco foi escolhido arbitrariamente em 3 meses porque o tempo de 3 meses se saiu melhor que o tempo de 6 meses, isso configura um viés de múltipla testagem, de modo que na prática o instrumento se desempenhará muito pior 
10. Foi realizada uma validação interna? Métodos de bootstrapping ou de dividir a amostra aleatoriamente em duas partes para obter o modelo são formas de validação interna.

Após a escolha do instrumento que melhor atenderá às necessidades de uma ARV, alguns cuidados importantes devem ser tomados em relação ao processo de obtenção de informação e de divulgação da avaliação:

Aspectos éticos e transparência: o indivíduo avaliado deve ser informado, em linguagem que consiga entender os motivos da avaliação, quem a solicitou, o que será feito durante o processo de avaliação e como as informações poderão ser utilizadas pelo solicitante (Mills, Kroner \& Morgan, 2011). Todo o processo deve ser bem documentado, referindo os instrumentos utilizados, as informações centrais e o raciocínio utilizado para chegar à conclusão, de modo que qualquer leitor possa entender ou que o próprio avaliador possa se recordar e obter as mesmas conclusões, mesmo transcorrido um período longo (Mills et al., 2011).

Obtenção das informações: o processo de avaliação deve ser embasado por evidências e o avaliador deve buscar informações em mais de uma fonte (Mills et al., 2011; Webster, Hucker \& Bloom, 2002). Se não há informações de mais de uma fonte, é preciso relatar essa limitação. Alguns exemplos de fontes são: entrevista com o avaliado (de preferência estruturada ou semiestruturada, com foco no objetivo da avaliação), testes psicométricos, contato colateral com familiares e outros profissionais, registros escolares, histórico infracional e observação direta.

Comunicação das conclusões: o relatório deve ser apresentado de forma lógica, concisa e em uma linguagem que os aplicadores da lei possam facilmente entender o que está sendo reportado (Webster, Hucker \& Bloom, 2002). O risco aferido refere-se a um período de tempo específico e as condições que aumentam ou diminuem/eliminam devem ser explicitadas, assim como as potenciais vítimas, quando essas parecem especificas como no caso de avaliação de violência de gênero, por exemplo (Webster, Hucker \& Bloom, 2002). Mills, Kroner e Morgan (2011) sugerem que as seguintes questões devem ser contempladas no relatório: Por que o avaliado está aqui? (Contexto da avaliação); Quem é o avaliado e de onde ele vem? (Background psicossocial); $O$ que o avaliado fez? (Histórico de comportamentos); e $O$ que pode ser feito em relação a isso? (Avaliação e gerenciamento do risco). 
Reavaliação: especialmente em contexto institucional, é importante que se faça reavaliações periódicas. Como as pessoas mudam, especialmente na adolescência, o processo de avaliação deve ser considerado válido por um período curto de aproximadamente seis meses (Borum, Bartel, \& Forth, 2002).

Considerados os aspectos teóricos e práticos da avaliação de risco de violência, cabe ressaltar que no Brasil ainda há pouco esforço em construir e/ou adaptar e validar protocolos estruturados para aplicação em contexto brasileiro. E, ao que se sabe, nenhum protocolo foi sistematicamente implementado pelo sistema de justiça juvenil ou criminal. Para a população adulta, há evidências de precisão e de validade preditiva do HCR-20 em contexto psiquiátrico forense, obtidas por Telles, Day, Folino e Taborda (2009) e Telles, Folino e Aborda (2012) em Porto Alegre, Rio Grande do Sul. Para a população juvenil, não há conhecimento sobre instrumentos de avaliação de risco de violência adaptados e validados em contexto brasileiro. Nesse sentido, a presente tese consiste em uma aproximação, em termos teóricos e práticos, da obtenção de um modelo que possa ser utilizado em contexto judiciário/forense brasileiro. 


\section{CAPÍTULO 4}

\section{ESTUDO EMPÍRICO: O DESENVOLVIMENTO DO COMPORTAMENTO VIOLENTO EM UMA AMOSTRA DE ADOLESCENTES EM CONFLITO COM A LEI}

Os estudos apontam que grande parte dos indivíduos processados/julgados no Sistema de Justiça Criminal/Adulto também estiveram envolvidos com o Sistema de Justiça Juvenil, na etapa da adolescência (Farrington, 2003; Loeber, Farrington \& Petechuk, 2013). Isso quer dizer que os responsáveis por parte considerável dos crimes conhecidos (oficiais) são adolescentes com significativo engajamento infracional e adultos que, quando jovens, também passaram pela Justiça Juvenil e se mantiveram envolvidos em atividades criminais, apresentando uma conduta delituosa persistente. Os estudos também apontam que um padrão de conduta violenta pode ser identificado desde cedo, de modo que o desenvolvimento deste tipo de comportamento pode ser prevenido, tanto em nível primário quanto secundário (Loeber \& Farrington, 1998). Evidencia-se, assim, a importância de identificar os fatores associados à manifestação e à manutenção da conduta delituosa violenta, na adolescência, e compreender como esses impactam o desenvolvimento psicossocial dos jovens, para lidar com o fenômeno da delinquência juvenil violenta.

No Brasil, padece-se da falta de estudos integrativos e longitudinais interessados nesse fenômeno, o que compromete bastante o tratamento jurídico e socioeducativo ao qual os jovens têm direito (Maruschi \& Bazon, 2014). Posto isso, o presente estudo teve como principal objetivo verificar, em dois tempos, os efeitos da exposição a variáveis de risco e de proteção para a delinquência violenta em uma amostra de adolescentes brasileiros em conflito com a lei. Hipotetizava-se que a exposição a um conjunto maior de variáveis especificas de risco para a violência, mediante a ausência de fatores protetivos, prediriam o envolvimento em delitos de natureza violenta. Esperava-se também que os fatores de risco e de proteção para a delinquência geral (não violenta) não interfeririam neste resultado.

O conceito de violência pode abarcar um grande conjunto de condutas ou situações. Cabe ressaltar que, no presente estudo, o conceito definido como "uso intencional e ilegítimo de poder ou força física, real ou sob a forma de ameaça, contra outra pessoa ou outras pessoas, que resulte ou tenha grande possibilidade de resultar em lesão, morte, dano psicológico, deficiência de desenvolvimento ou privação", foi utilizado como crivo para distinguir certas condutas delituosas, tipificadas no Código Penal Brasileiro, envolvendo 
diretamente vítimas - conhecidas ou desconhecidas - de ações com potencial de causar-lhes danos físicos e psicológicos, em contraste a outras consideradas não violentas. Operacionalmente, os delitos violentos caracterizam-se como: ações imbuídas de agressão suficientemente grave para causar dano às pessoas (cortes, hematomas, fraturas e até óbito); ações que coagem e/ou forçam a vítima a fazer algo que não queira; ações realizadas com ameaça feita com auxílio de uma arma. Dada a potencialidade dos delitos violentos em causar danos severos e permanentes às vítimas, a categoria tem sido considerada a mais grave e a que mais preocupa sociedade e autoridades, de modo que sua prevenção - primária e secundária consiste em um desafio prioritário das políticas públicas (Borum, Bartel \& Forth, 2006). Adianta-se que, no presente estudo, em função do instrumento utilizado para a coleta de dados, focalizou-se especificamente os delitos "roubo", "rixa" e "lesão corporal", em contraste a outros delitos considerados não violentos ("dano", "furto", "receptação", tráfico de drogas", "porte ilegal de armas").

\subsection{Objetivos específicos}

Os objetivos específicos no tempo um (T1) foram: caracterizar a amostra em relação às variáveis independentes (fatores de risco e de proteção avaliados pelos instrumentos empregados) e dependentes (comportamentos delituosos avaliados por questionário de autorrelato e por registros oficiais).

Os fatores de risco mensurados, gerais (relacionados à delinquência de forma geral) e específicos (relacionados à delinquência violenta - em negrito), estão descritos na Tabela 4.1: 
Tabela 4.1

Fatores de risco associados à delinquência e instrumentos utilizados para mensurá-los

\begin{tabular}{|c|c|}
\hline Construtos & Escalas e Instrumentos utilizados \\
\hline \multicolumn{2}{|l|}{ Fatores Históricos } \\
\hline Eventos estressores & $\begin{array}{l}\text { - Estresse em contexto escolar }(\mathrm{QCJ}) \\
\text { - Percepção de violência e criminalidade no bairro (QCJ) }\end{array}$ \\
\hline $\begin{array}{l}\text { Histórico de problemas de } \\
\text { conduta }\end{array}$ & $\begin{array}{l}\text { - Comportamentos antissociais não violentos (QCJ) } \\
\text { - Histórico de delito violento autorrevelado (QCJ) e } \\
\text { oficial } \\
\text { - Histórico de problemas com a polícia e a justiça (QCJ) } \\
\text { - Problemas de comportamento em contexto escolar (QCJ) }\end{array}$ \\
\hline $\begin{array}{l}\text { Fracasso em intervenções } \\
\text { anteriores }\end{array}$ & $\begin{array}{l}\text { - Número de medidas socioeducativas anteriores } \\
\text { (informação oficial) }\end{array}$ \\
\hline Atraso escolar & $\begin{array}{l}\text { - Idade cronológica menos idade escolar (Atraso Escolar; } \\
\text { QCJ) }\end{array}$ \\
\hline \multicolumn{2}{|l|}{ Fatores Pessoais } \\
\hline Autocontrole (baixo) & $\begin{array}{l}\text { - Agressividade Manifesta (IJ-R-Br) } \\
\text { - Desadaptação Social (IJ-R-Br) } \\
\text { - Impulsividade (QCJ) }\end{array}$ \\
\hline Traços de psicopatia & (não foi mensurado no presente estudo) \\
\hline Emotividade negativa & $\begin{array}{l}\text { - Ansiedade Social (IJ-R-Br) } \\
\text { - Retraimento/Depressão (IJ-R-Br) }\end{array}$ \\
\hline Transtornos de Saúde Mental & $\begin{array}{l}\text { - Transtorno de Conduta (IJ-R-Br) } \\
\text { - Transtorno Opositivo Desafiador (IJ-R-Br) }\end{array}$ \\
\hline $\begin{array}{l}\text { Problemas com abuso de } \\
\text { substâncias }\end{array}$ & - Frequência do uso de álcool, maconha e outras drogas \\
\hline Valores e Atitudes & $\begin{array}{l}\text { - Atitude Violenta (QCJ) } \\
\text { - Índice de Associabilidade (IJ-R-Br) } \\
\text { - Orientação de Valores (IJ-R-Br) } \\
\text { - Valores Antissociais (QCJ) }\end{array}$ \\
\hline \multicolumn{2}{|l|}{ Fatores contextuais } \\
\hline Rotina & $\begin{array}{l}\text { - Envolvimento em atividades pró-sociais (QCJ) } \\
\text { - Rotina Desestruturada (QCJ) }\end{array}$ \\
\hline Ambiente escolar & - Desorganização escolar (QCJ) \\
\hline Ambiente comunitário & $\begin{array}{l}\text { - Bairro Deteriorado (QCJ) } \\
\text { - Controle Formal (QCJ) } \\
\text { - Controle Informal (QCJ) }\end{array}$ \\
\hline Pares infratores & - Pares Infratores (QCJ) \\
\hline Isolamento social & - Retraimento/Depressão (IJ-R-Br) \\
\hline Inabilidade parental & - Supervisão Parental (QCJ) \\
\hline
\end{tabular}


Os fatores de proteção, gerais e específicos à violência (em negrito), estão descritos na tabela 4.2:

Tabela 4.2

Fatores de risco associados à delinquência e instrumentos utilizados para mensurá-los

\begin{tabular}{ll}
\hline Construtos & Aspectos mensurados \\
\hline Fatores Internos & \\
\hline Autocontrole & $\begin{array}{l}\text { (Baixa) Impulsividade (QCJ) } \\
\text { Funções executivas (TS-V e TOL) }\end{array}$ \\
\hline Empatia & (não foi mensurado no presente estudo) \\
\hline Inteligência & Funções executivas (TS-V e TOL) \\
\hline Fatores Motivacionais & \\
\hline Atitudes Positivas frente às autoridades & (não foi mensurado no presente estudo) \\
\hline & $\begin{array}{l}\text { Valores positivos frente à escola e aos estudos } \\
\text { (QCJ) }\end{array}$ \\
Compromisso com a escola ou o trabalho & $\begin{array}{l}\text { Vínculo Escolar (QCJ) } \\
\text { Bom desempenho acadêmico (QCJ) }\end{array}$ \\
\hline Fatores Externos & \\
\hline Apoio Social & Apoio Social (QCJ) \\
\hline & Apego parental (QCJ) \\
Vínculo com adultos pró-sociais & Investimento Familiar (QCJ) \\
& Vínculo com a escola (QCJ) \\
\hline
\end{tabular}

No tempo dois (T2), além da caracterização da amostra, semelhantemente ao realizado no T1, acrescentaram-se os seguintes objetivos específicos: identificar as variáveis que discriminariam os adolescentes que se envolveram e os que não se envolveram em delitos violentos, do T1 ao T2; determinar o peso das variáveis discriminantes, no tocante à sua capacidade de predição da conduta violenta; testar, de modo restrospectivo, o poder preditivo dessas variáveis em uma subamostra de adolescentes infratores cujos dados não teriam sido utilizados para a composição do modelo preditivo. 


\subsection{Método}

Este estudo possui delineamento longitudinal retrospectivo e prospectivo, do tipo descritivo, comparativo e preditivo. Os participantes foram contatados e entrevistados em um primeiro momento, entre janeiro e agosto de 2015, ocasião em que foram coletados dados relativos às variáveis de interesse, referentes ao tempo passado e ao presente. Em um segundo momento, entre junho de 2016 e março de 2017, buscou-se recontratar todos os mesmos participantes, de forma que se voltou a coletar dados relativos às variáveis de interesse nessa ocasião $^{8}$, referentes ao tempo passado e ao presente.

\subsubsection{Aspectos éticos}

Conforme recomenda a Resolução 466/12 do Conselho Nacional de Saúde, o projeto de pesquisa foi encaminhado à análise do Comitê de Ética em Pesquisa com Seres Humanos, da Faculdade de Filosofia, Ciências e Letras de Ribeirão Preto, da Universidade de São Paulo, e teve início mediante aprovação do referido comitê (CAAE 49125415.0.0000.5407). A participação dos adolescentes, no T1, dependeu da autorização das Instituições onde foram recrutados: ONGs responsáveis pela execução de Programas de Medida de Liberdade Assistida, no município de Ribeirão Preto, e a Fundação CASA, concernindo Unidade de Internação específica, também no município de Ribeirão Preto, além da anuência do Juiz da Vara da Infância e Juventude no caso dos adolescentes que estavam internados. Ademais, mediante essas autorizações, buscou-se o aceite dos próprios adolescentes, atestado por meio do Termo de Assentimento. A participação dos adolescentes no T2, na medida em que o recrutamento dos mesmos aconteceu na comunidade, transcorreu após o aceite dos adolescentes, mediante a assinatura em um novo Termo de Assentimento e da autorização dos pais ou responsáveis, com a assinatura em um Termo de Consentimento Livre e Esclarecido, no caso dos menores de idade, e do aceite e assinatura em Termo de Consentimento Livre e Esclarecido específico, apresentado àqueles que, neste momento, já eram maiores de idade.

\footnotetext{
${ }^{8}$ Conforme será explicado na seção de participantes, de um tempo a outro houve perda de 51 adolescentes.
} 


\subsubsection{Participantes}

O presente estudo contou com a participação de adolescentes do sexo masculino que tinham, no T1, processos judiciais de execução de medida socioeducativa no município de Ribeirão Preto - SP. Nesta etapa, foram recrutados 130 adolescentes em duas instituições responsáveis por executar a medida de Liberdade Assistida, no município, e em uma Unidade de Internação da Fundação CASA, também no município.

No T2, aproximadamente 18 meses passados da data da primeira coleta de dados, empreendeu-se procedimentos para a localização/busca/contato com esses mesmos 130 adolescentes, dos quais 78 foram localizados e aceitaram a participar da pesquisa nesta segunda etapa.

Do total de 130 adolescentes que participaram da primeira etapa (T1), 12, inusitadamente, não foram localizados a partir dos dados do Sistema de Justiça Juvenil, nem por nome, nem por RG, o que inviabilizou a tentativa de contatá-los para a segunda etapa da pesquisa (T2); assim, esses 12 adolescentes tiveram seus dados excluídos de todas as análises. Dos 118 restantes, 39 não participaram da segunda etapa: 36 por não serem localizados por meio dos dados de contato disponibilizados; 3 por não aceitarem participar da pesquisa quando localizados e contatados. Deste modo, tem-se que 118 adolescentes participaram da primeira etapa da pesquisa (T1), todos do sexo masculino, com idades entre 15 e 19 anos (M $=17,8 ; \mathrm{DP}=0,8)$, distribuídos nas seguintes classes sociais segundo o Critério de Classificação Socioeconômica Brasil (CCSB) estabelecido pela Associação Brasileira de Empresas de Pesquisa (ABEP, 2014): A2 (1,5\%), B1 (1,5\%), B2 (21,5\%), C1 (43,8\%), C2 $(26,9 \%)$ e D (4,6\%). Na segunda etapa (T2), participaram 78 adolescentes que foram recuperados do T1. Esses 78 adolescentes remanescentes tinham idades entre 16 e 20 anos (M $=19,2 ; \mathrm{DP}=0,9)$, nesta segunda etapa e se alocaram nas classes sociais, segundo os mesmos critérios, da seguinte forma: B1 (2,5\%), B2 (12,7\%), C1 (54,4\%), C2 (25,3\%) e D $(5,1 \%)$. 


\subsubsection{Instrumentos}

Inúmeros estudos já realizados focalizaram os fatores de risco e de proteção associados à delinquência e à delinquência violenta e identificaram dezenas de variáveis relevantes. $\mathrm{Na}$ seção 3.3 foram apresentados os fatores mais relevantes identificados na literatura especializada de estudos empíricos e de protocolos de ARV. No presente estudo se aborcou alguns deles, em razão de diferentes limitações, dentre as quais o alcance dos instrumentos e procedimentos empregados na coleta de dados. Ressalta-se que os instrumentos descritos, embora não deem conta de todas as variáveis apontadas na literatura, exploram variáveis pessoais e sociais importantes, que os estudos revisados apresentados verificaram ter significativo poder preditivo.

\subsubsection{Questionário Sobre Comportamentos Juvenis (QCJ)}

O Instrumento original, a partir do qual se formatou a versão do QCJ empregado no presente estudo, foi desenvolvido para o projeto Observatório de Delinquência Juvenil, resultado de uma parceria entre a Escola de Criminologia da Universidade do Porto e o governo português para estabelecer dados sobre a relação entre padrões específicos de comportamento divergentes e delituosos e características individuais, relacionais e sociais dos jovens (Castro, Cardoso \& Agra, 2010). A estrutura do instrumento se assemelha ao questionário utilizado no International Self-Report Delinquency Study (ISRD), que explora informações sobre seis grandes dimensões: (1) o adolescente: idade, escolaridade, religião, temperamento, atitudes e valores; (2) a família: status socioeconômico, número de pessoas e vínculo, investimento e supervisão parental; (3) rotina e amigos: o que faz e onde vai quando tem tempo livre e o tipo de amigos (se são pró ou antissociais); (4) escola: desempenho acadêmico, estresse escolar e valores em relação aos estudos; (5) bairro: características do bairro/vizinhança e dos vizinhos; (6) comportamentos antissociais: comportamentos divergentes (ex.: uso de álcool ou outras drogas) e delituosos (ex.: furto, roubo).

Conforme descrito no relatório final do projeto (Castro, Cardoso \& Agra, 2010), a construção da versão definitiva do QCJ envolveu atividades de revisão da literatura científica, incluindo questionários utilizados em outros países, interlocução com equipes de investigadores europeus no sentido de discutir aspectos teóricos e metodológicos e duas fases de estudos pilotos. Na primeira fase, foram realizadas aplicações individuais do questionário para verificar aspectos da adequação da linguagem utilizada nas questões e facilitar a 
compreensão dos sujeitos, e para adequar o design do questionário, procurando reduzir as dificuldades e erros de preenchimento. Na segunda fase, foram realizadas 3 aplicações em dois estabelecimentos de ensino para verificar questões técnicas como tempo de aplicação e testar as instruções de preenchimento e os procedimentos das aplicações.

O QCJ foi, então, adequado ao contexto brasileiro por Komatsu (2014), fruto da proximidade entre o grupo de pesquisa português e o Grupo de Estudos e Pesquisa em Desenvolvimento e Intervenção Psicossocial (GEPDIP) da Faculdade de Filosofia, Ciências e Letras de Ribeirão Preto (FFCLRP) da Universidade de São Paulo (USP), contexto no qual se desenvolveu a presenta pesquisa. Subsequentemente, o GEPDIP utilizou o QCJ em estudos junto a diferentes populações: adolescentes de escolas particulares (Visioli, 2017); adolescentes em conflito com a lei (Komatsu \& Bazon, 2017b); adolescentes do sexo feminino (Salgado, 2017). As qualidades psicométricas do QCJ foram descritas por Komatsu, Costa, Salgado e Bazon (2019), com base em uma amostra de 836 estudantes do sexo masculino (11 e 18 anos) de três cidades da região sudeste do Brasil. Os alfas de Cronbach variaram de 0,23 a 0,89 e as correlações intradomínio foram significativas em $81 \%$ dos casos, com coeficientes variando de 0,10 a 0,54. As correlações entre as escalas e os Comportamentos Externalizantes foram significativas em $62 \%$ dos casos, variando de 0,10 a 0,43 . O QCJ mostrou-se útil para rastrear problemas sociais, relacionais e comportamentais na população adolescente.

O questionário possui 56 questões com 264 subitens de autopreenchimento. O instrumento foi concebido para ser autoaplicável, mas também pode ser aplicado por meio de entrevista no caso de participantes com dificuldades de leitura. O tempo médio de aplicação é de aproximadamente 40 minutos. Os itens do QCJ relacionados aos fatores explanatórios foram analisados e agrupados em diferentes constructos/escalas a partir do julgamento de juízes. As análises subsequentes mostraram que as escalas foram capazes de distinguir adolescentes com diferentes níveis de engajamento infracional a partir do autorrelato dos comportamentos delituosos, de modo que os grupos com piores médias nas subescalas eram os mesmos com nível de engajamento infracional mais elevado (Komatsu, 2014; Komatsu \& Bazon, 2017a, 2017b). Posteriormente, alguns itens foram adicionados ao QCJ e algumas escalas foram reformuladas e outras foram criadas, resultando em um instrumento com 23 escalas divididas nos domínios Pessoal (5), Familiar (3), Escolar (7), Rotina e Pares (3) e Comunidade e Apoio Social (5), descritos a seguir:

O domínio Pessoal é composto pelas subescalas de Impulsividade, Valores Antissociais, Atitude Violenta, Oposição a Figuras de Autoridade e Histórico de Problemas 
com a Polícia e a Justiça. Cada subescala é composta por um conjunto de itens que remetem a diferentes indicadores que comporiam o risco ou a proteção representada pela escala. As respostas aos itens são codificadas a fim de estabelecer se o indicador está ausente (0) ou presente (1) para o participante avaliado. Ao final, os itens são somados e a pontuação pode variar de zero (nenhum fator presente) até o número total de itens que compõem a subescala em questão (todos os fatores presentes).

A escala de Impulsividade remete a um temperamento aferido por uma classe de comportamentos que indicam dificuldade em exercer o autocontrole. Dos cinco itens que compõem esta subescala, três requerem dos participantes que respondam se as situações descritas a respeito deles próprios acontece "muitas vezes" (1) ou "poucas vezes" (0): 1) "Faço as coisas sem pensar", 2) "Me sinto inquieto em aulas ou palestras", 3) "Perco a cabeça". Os outros dois são do tipo "concorda" (1) ou "discorda" (0): 4) "Devemos viver o presente sem nos preocuparmos com o futuro" e 5) "Às vezes quebro as regras porque ajo sem pensar". Quanto maior a pontuação, maior a impulsividade aferida. Por representar aspectos do autocontrole, espera-se que essa escala possa diferenciar infratores violentos dos não violentos.

Os Valores Antissociais referem-se a uma crença que sustenta a aceitação/naturalização de comportamentos antissociais. Este construto é aferido por um conjunto de oito itens, mediante os quais os adolescentes têm de dizer se acham "grave ou muito grave" (0) ou "pouco ou nada grave" (1) o comportamento descrito: 1) "Danificar propositalmente algo que não lhe pertence", 2) "Faltar às aulas sem motivo sério que o justifique", 3) "Entrar em um carro para roubar algo do seu interior", 4) "Pegar dinheiro ou outra coisa que não lhe pertence em casa ou na escola", 5) "Pegar alguma coisa de uma loja sem pagar", 6) "Roubar um carro", 7) "Entrar em uma casa para roubar" e 8) "Bater em alguém". Quanto maior a pontuação, maior o nível de valores antissociais aferido. Por se tratar de valores antissociais gerais, espera-se que essa escala seja indiferente em relação à distinção de infratores violentos e de não violentos.

A Atitude Violenta refere-se à aceitação da violência envolvendo comportamentos de agressão física e/ou destrutivo. Essa é aferida por quatro afirmações mediante as quais os adolescentes têm que se posicionar favorável ("concorda": 1) ou desfavorável ("discorda": 0): 1) "Um pouco de violência faz parte da diversão", 2) "Uma pessoa tem que usar a força para ser respeitado", 3) "Se alguém me agredir, eu revido" e 4) "Não faz mal bater em alguém se ele insultou meus familiares". Quanto maior a pontuação, maior a aceitação da 
violência, ou seja, mais consolidada é a atitude violenta aferida e, portanto, espera-se que essa escala diferencie infratores violentos dos não violentos.

A Oposição a Figuras de Autoridade remete a uma disposição negativa frente às normas e aos comandos de autoridade. Esse constructo foi aferido por meio de três itens do tipo "concordo" (1) e "discordo" (0): 1) "Quando adulto me manda fazer algo, tenho vontade de fazer o contrário", 2) "A maioria das pessoas que mandam são metidas" e 3) "Quando um adulto me repreende sinto raiva e brigo ou discuto com ele". Quanto maior a pontuação, maior o nível de oposição aferido. Espera-se que essa escala diferencie infratores violentos de não violentos.

O Histórico de Problemas com a Polícia e a Justiça consiste em uma medida contínua do número de vezes que o adolescente relata ter tido problemas com a polícia somado ao número de vezes que diz ter ido ao Juiz responder por algo que tenha feito. Quanto maior a pontuação, maior o nível de problemas com a polícia e a justiça aferido. Essa escala não se relaciona diretamente com a violência, mas em alguma medida remete a um enfrentamento a figuras de autoridade, podendo distinguir infratores violentos de não violentos.

Passando para o domínio da Família, as três subescalas são Investimento Familiar, Apego Parental e Supervisão Parental. O Investimento Familiar refere-se ao tempo despendido em atividades compartilhadas entre pais e filhos e foram avaliados por dois indicadores: 1) “Quantas vezes por semana costuma jantar com os seus pais?”, pontuando um no caso de 5 ou mais vezes e zero no caso de 4 ou menos vezes; e 2) "Brinco ou pratico esportes com meus pais", pontuando um no caso de "muitas vezes" ou "sempre" e zero no caso de "poucas vezes" ou "quase nunca". Não se espera que essa escala diferencia infratores violentos dos não violentos.

O Apego Parental indica a qualidade do relacionamento com os pais e foi avaliado por quatro indicadores: 1) "Em geral, como é a relação que você tem com sua mãe (ou adulto que desempenha o papel de mãe)?", pontuando um no caso de resposta "boa" ou "muito boa" e zero no caso de "não muito boa", "ruim" ou "não vivo com ela"; 2) "Em geral, como é a relação que você tem com seu pai (ou adulto que desempenha o papel de pai)?”, pontuando um no caso de resposta "boa" ou "muito boa" e zero no caso de "não muito boa", "ruim" ou "não vivo com ele"; 3) "Com que frequência conversa com seus pais", pontuando um no caso de "sempre" ou "muitas vezes" e zero no caso de "poucas vezes" ou "nunca"; 4) "Com que frequência mente para seus pais", pontuando um no caso de "nunca" ou "poucas vezes" e um no caso de "muitas vezes" ou "sempre". Não se espera que essa escala diferencie infratores violentos dos não violentos. 
A Supervisão Parental refere-se às práticas de monitoramento das condutas dos adolescentes pelos pais, sendo avaliada por cinco itens/indicadores: 1) "Quando sai à noite, seus pais dizem a hora que deve voltar?", pontuando um no caso de "sim, quase sempre" e zero no caso de "poucas vezes" ou "nunca"; 2) "Alguma vez passou a noite fora de casa sem que seus pais soubessem onde estava?", pontuando um no caso de "nunca" e zero no caso de "uma ou algumas vezes" ou "muitas vezes"; 3) "Com que frequência seus pais conferem sua tarefa?", pontuando um no caso de "sempre" ou "muitas vezes" e zero no caso de "poucas vezes" ou "nunca"; 4) "Com que frequência seus pais te encorajam em relação aos estudos?”, pontuando um no caso de "sempre" ou "muitas vezes" e zero no caso de "poucas vezes" ou “nunca"; 5) "Seus pais conhecem seus amigos?", pontuando um no caso de "a maioria" e zero no caso de "alguns" ou "nenhum". Espera-se que essa escala diferencie infratores violentos dos não violentos.

No domínio escolar, as sete subescalas são: Escola desorganizada, Estresse em contexto escolar, Vínculo escolar, Valores positivos frente à escola e aos estudos, Bom Desempenho Acadêmico, Problemas de Comportamento em Contexto Escolar e Atraso Escolar. O conceito de Escola Desorganizada refere-se ao nível de problemas de comportamento em âmbito escolar e da deterioração das instalações. Esta subescala foi avaliada por cinco indicadores em que o adolescente poderia "concordar" ou "descordar" em relação à própria escola: 1) "Tem muitos roubos"; 2) "Tem muitas brigas"; 1) "Tem muita indisciplina em sala de aula"; 1) "Tem muito consumo de álcool e drogas"; 1) "Tem muita coisa quebrada". Não se espera que essa escala tenha relação com delitos violentos.

O Estresse em Contexto Escolar refere-se a sensações de insegurança e situações de vitimização em contexto escolar. Três itens avaliaram sensações de insegurança, pontuando um no caso de se sentir "pouco seguro" ou "nada seguro" nas seguintes situações: 1) "No caminho até a escola"; 2) "Em sala de aula"; 3) "Durante o recreio". E oito itens avaliaram situação de vitimização, pontuando um se passaram por alguma dessas situações nos últimos 12 meses: 4) "Me zoaram"; 5) "Me bateram"; 6) "Espalharam boatos sobre mim"; 7) "Me ameaçaram"; 8) "Me bateram com algum instrumento"; 9) "Me furtaram"; 10) "Me roubaram"; 11) "Me desrespeitaram por causa da minha cor ou outra característica física". Por compor uma fonte importante de estresse e exposição à violência, espera-se que essa escala discrimine adolescentes infratores violentos dos não violentos.

O Vínculo Escolar foi avaliado por dois indicadores em relação à opinião sobre a escola e sobre os professores, pontuando um no caso de "concorda" e zero no caso de "discorda": 1) "Não gostaria de mudar de escola"; 2) "Tenho bons professores". Embora o 
vínculo escolar seja referido na literatura como uma fonte de proteção, não se espera que os indicadores utilizados por essa escala discriminem infratores violentos dos não violentos.

Os Valores Positivos Frente à Escola e aos Estudos foram avaliados por três indicadores em relação ao interesse pelos estudos e às expectativas em relação ao que os estudos podem proporcionar, pontuando um no caso de "concorda" e zero no caso de “discorda": 1) "Em geral, gosto de estudar", 2) "A escola me ensina coisas úteis que vão me ajudar no futuro"; 3 ) "A escola me ajudará a arranjar um bom emprego". Na medida em que essa natureza de valores pode representar um compromisso com a escola, espera-se que possa atuar como fator de proteção, distinguindo infratores violentos de não violentos.

O Bom Desempenho Acadêmico refere-se aos resultados escolares e foi avaliado por um único item de percepção sobre o próprio rendimento escolar em relação aos colegas: 1) "Como você avalia os seus resultados escolares quando os compara com os dos seus colegas?", pontuando um no caso de "melhor que a média" e zero nos casos de "na média" ou "abaixo da média". Resultados acima da média seriam considerados como fator protetivo, denotando envolvimento com a escola e com os estudos. Todavia, a confiabilidade deste item depende da acurácia da percepção do próprio indivíduo.

Os Problemas de Comportamento em Contexto Escolar foram avaliados por cinco indicadores: 1) "Matou aula nos últimos 12 meses?", pontuando no caso de uma ou mais vezes; 2) "Você já foi chamado para conversar com o diretor?", pontuando no caso de uma ou mais vezes; 3) "Você já foi advertido na escola?", pontuando no caso de uma ou mais vezes; 4) “Você já foi suspenso?”, pontuando no caso de uma ou mais vezes; 5) "Você já se sentiu forçado a mudar de escola porque não gostavam do seu comportamento?", pontuando no caso de resposta positiva. Por se tratar de itens de problemas de comportamento geral, não se espera que essa escala diferencie infratores violentos dos não violentos. E o Atraso Escolar foi avaliado pela comparação entre idade cronológica e idade escolar, contabilizando-se, assim, o número de anos atrasados em relação ao que era esperado.

No domínio da rotina e dos pares, as três subescalas são: Rotina Desestruturada; Envolvimento em Atividades Pró-sociais; Pares Infratores. A Rotina Desestruturada avalia a frequência com a qual o jovem passa tempo o tempo livre envolvido em atividades sem supervisão de adultos, avaliada por sete itens: 1) "Com quem passa o tempo livre", pontuando em caso de passar com muitos amigos ou sozinho; 2) "Quantos dias por semana você costuma sair à noite para ir a alguma festa ou dar uma volta pela rua?", pontuando em caso dos dias serem superiores a dois; 3) "Com que frequência costuma sair com amigos para beber álcool?", pontuando nos casos de "sempre" ou "muitas vezes"; 4) "Com que frequência 
costuma sair com amigos para arrumar confusão?", pontuando nos casos de "sempre" ou "muitas vezes"; 5) "Com que frequência costuma sair com amigos para usar drogas?”, pontuando nos casos de "sempre" ou "muitas vezes"; 6) "Com que frequência costuma sair com amigos para quebrar coisas?", pontuando nos casos de "sempre" ou "muitas vezes"; 7) “Com que frequência costuma sair com amigos para zoar pessoas?”, pontuando nos casos de "sempre" ou "muitas vezes". Não se espera que essa escala diferencia infratores violentos dos não violentos.

O Envolvimento em Atividades Pró-Sociais foi avaliado por quatro itens: 1) "Você trabalha?", pontuando em caso de trabalhar a 1 ano ou mais; 2) "Você é praticante de alguma religião? (Vai a reuniões religiosas com frequência e segue o que prega a religião)?”, pontuando em caso de resposta positiva; 3) "Com que frequência costuma sair com amigos para tocar em uma banda ou grupo musical?", pontuando nos casos de "sempre" ou "muitas vezes"; 4) "Com que frequência costuma sair com amigos para praticar esportes?", pontuando nos casos de "sempre" ou "muitas vezes". Não se espera que essa escala diferencie infratores violentos de não violentos.

Os Pares Infratores refere-se à associação a pessoas da mesma faixa etária com implicação em atividade antissocial; essa foi aferida por 11 itens do tipo sim (1) e não (0): "Algum de seus amigos já fez as seguintes coisas..." 1) "Pegar alguma coisa de uma loja sem pagar?", 2) "Pegar dinheiro ou outra coisa de alguém sem que ela percebesse no momento?", 3) "Andar armado", 4) "Destruir alguma coisa que não lhe pertence", 5) "Vender drogas", 6) "Bater em alguém", 7) "Roubar um carro ou uma moto", 8) "Invadir alguma casa com a intenção de roubar", 9) “Ameaçar alguém com a intenção de conseguir dinheiro", 10) "Bater em alguém com algum instrumento" e 11) "Abrir um carro para roubar algo do seu interior". Espera-se que essa escala diferencia infratores violentos de não violentos.

No domínio da Comunidade e Apoio Social, as cinco subescalas que o compõe são: Bairro deteriorado, Percepção de violência e criminalidade no bairro, Controle Informal no bairro, Controle Formal no bairro e Apoio Social. A deterioração do bairro foi avaliada por três indicadores: 1) "Meu bairro é visto como um bom bairro para se morar", pontuando em caso de resposta negativa; 2) "Tem muitos lugares pichados no meu bairro", pontuando em caso de resposta afirmativa; 3) "Tem muitas casas abandonadas em meu bairro", pontuando em caso de resposta afirmativa.

A Percepção de violência e criminalidade no bairro remete a situações geradoras de estresse vividas pelo adolescente e que também pode funcionar como fonte de modelação de 
sua conduta na comunidade em que vive. O constructo foi aferido por quatro itens do tipo "concordo" (1) ou "discordo" (0) em relação às condições do bairro em que vive: 1) "Tem muito tráfico de drogas", 2) "Tem muitas discussões violentas entre os vizinhos", 3) "Tem muita criminalidade" e 4) "Tem gente que arruma encrenca". Pelas evidências da literatura, espera-se que essa escala diferencie adolescentes infratores violentos de não violentos.

Os mecanismos de Controle Formal e Informal foram avaliados por dois itens: 1) "Se no seu bairro os jovens estiverem na rua gritando ou insultando as pessoas que passam, seria provável que..." a) "um adulto desse bronca e os mandasse parar", b) "alguém chamasse a polícia"; 2) 1) "Se no seu bairro os jovens estiverem pichando um muro,, seria provável que..." a) "um adulto desse bronca e os mandasse parar", b) "alguém chamasse a polícia". Pontua como controle formal quando "seria muito provável" que alguém chamasse a polícia e pontua como controle informal quando "seria muito provável" que um adulto resolvesse a situação. Os mecanismos de controle estão associados com a delinquência geral, por isso não se espera que diferenciem infratores violentos dos não violentos.

Por fim, condutas antissociais - divergências e delitos - representam a parte mais extensa do QCJ, composta por um conjunto de 20 itens que investigam os comportamentos antissociais. Sete desses itens referem-se a condutas divergentes e 13 a condutas delituosas. A Tabela 4.3 apresenta todas as 20 condutas antissociais avaliadas. Para cada conduta, o instrumento requer que o participante adolescente responda se já teria apresentado a referida conduta alguma vez (no curso de sua vida). Em caso de resposta afirmativa, perguntas sucedem, questionando quantas vezes o participante teria emitido tal conduta nos últimos 12 meses. Essa informação fornece a prevalência e a frequência do comportamento no último ano. Entre os 13 delitos investigados, quatro foram considerados delitos violentos por se enquadrarem na definição adotada por este estudo, relativa à de violência interpessoal, no contexto da consecução de um delito: roubo, rixa, lesão corporal em que a vítima precisou de auxílio médico e lesão corporal com uso de instrumento. 
Tabela 4.3

Condutas antissociais avaliadas pelo Questionário sobre Comportamentos Juvenis (QCJ)

\begin{tabular}{|c|c|}
\hline Condutas & Pergunta: "Alguma vez você...." \\
\hline \multicolumn{2}{|l|}{ Divergentes } \\
\hline $\begin{array}{l}\text { Cabular aula (faltar às } \\
\text { aulas de forma } \\
\text { injustificada) }\end{array}$ & "Matou ou encanou aula?" \\
\hline $\begin{array}{l}\text { Consumo de bebidas } \\
\text { alcoólicas }\end{array}$ & "Bebeu cerveja ou vinho?” \\
\hline $\begin{array}{l}\text { Consumo de bebidas } \\
\text { alcoólicas fortes }\end{array}$ & "Bebeu vodka, whisky, tequila, pinga ou rum?" \\
\hline Consumo de maconha & "Fumou maconha?” \\
\hline $\begin{array}{l}\text { Consumo de outras } \\
\text { drogas }\end{array}$ & "Fez uso de outras drogas sem ser a maconha?" \\
\hline $\begin{array}{l}\text { Direção sem Carteira } \\
\text { Nacional de Habilitação } \\
(\mathrm{CNH})\end{array}$ & "Dirigiu um carro ou uma moto sem carteira de habilitação?" \\
\hline Evasão do Lar & $\begin{array}{l}\text { "Passou a noite fora de casa sem que seus pais (ou responsáveis) } \\
\text { soubessem onde estava?" }\end{array}$ \\
\hline
\end{tabular}

\section{Delituosas}

Dano "Destruiu ou danificou, propositalmente, algum objeto público ou
privado?"

Furto "Pegou dinheiro ou outra coisa de alguém sem que ela percebesse no momento?"

Furto em "Pegou alguma coisa e não pagou em algum estabelecimento estabelecimento comercial?"

comercial

Furto no interior de "Roubou alguma peça de um carro ou algo do seu interior?" veículos

Furto/roubo de carro ou "Roubou um carro ou uma moto?" moto

\section{Roubo}

"Roubou dinheiro ou outra coisa de alguém à força?”

Porte ilegal de arma de fogo

“Andou armado?” (em seguida solicitava-se para assinalar o tipo

Receptação de arma).

\section{Lesão corporal}

"Comprou ou vendeu alguma coisa que soubesse que tinha sido roubada?"

“Bateu em alguém?" (Se sim, segue-se a pergunta "A pessoa precisou de cuidados médicos?". Para evitar contabilizar brigas sem grande importância, apenas nos casos afirmativos para esta 
segunda questão foram considerados Lesão Corporal)

Rixa

"Participou de uma luta em grupo?”

Maus-tratos contra "Feriu ou maltratou animais de propósito?" animais

Lesão corporal com uso de instrumento

“Bateu em alguém com algum instrumento?”

Tráfico de drogas

"Vendeu drogas ou desempenhou algum papel na venda de drogas?"

\subsubsection{Inventário de Jesness - Revisado Brasileiro (IJ-R-Br)}

No presente estudo buscou-se também avaliar crenças, atitudes, percepções e sentimentos para comportamentos impulsivos e hostis, o que reflete, em boa medida, o modo de funcionamento do indivíduo em diferentes situações, especialmente as relacionadas a condutas antissociais. Para tanto, utilizou-se a versão brasileira, adaptada e validada, do Inventário de Jesness - Revisado (IJ-R: Jesness, 2003). O instrumento possui 160 questões do tipo Verdadeiro/Falso que compõem 10 escalas que representam traços de personalidade do indivíduo: Desadaptação Social (DS), Orientação de Valores (OV), Imaturidade (IM), Autismo (AU), Alienação (AL), Agressividade Manifesta (AM), Retraimento-Depressão (RT/DEP), Ansiedade Social (AS), Repressão (REP) e Negação (NEG); duas escalas referentes a tipologias descritas na quarta edição do Manual Diagnóstico e Estatístico de Transtornos Mentais (DSM-IV): Transtorno de Conduta (TC) e Transtorno Opositor Desafiador (TOD); e um índice relacionado ao potencial de reincidência de jovens infratores: Índice de Associabilidade (IA).

O conteúdo das escalas foi amplamente descrito no trabalho de Bazon (2016) e encontra-se sintetizado aqui, na tabela 4.4. O IJ-R ajuda a classificar e compreender aspectos subjetivos associados às condutas antissociais, especialmente às delitivas e, assim, a empreender intervenções com adolescentes infratores, o que faz dele um dos instrumentos de avaliação de personalidade mais utilizados no Sistema de Justiça Juvenil norte-americano (Semel, 2016). Na correção do instrumento, a pontuação bruta de cada escala é transformada em um escore $T$, que nada mais é do que o respectivo escore $z$ multiplicado por 10 e somado 50, resultando em uma distribuição aproximadamente normal com média 50 e desvio-padrão 10. Dessa forma, interpreta-se o escore como dentro da faixa normativa de um desvio-padrão 
para baixo ou para acima, portanto, entre 40 e 60 pontos. Escores abaixo ou acima dessa pontuação são considerados disfuncionais.

No Brasil, o IJ-R foi traduzido e adequado semanticamente por Manzi-Oliveira (2012), o que deu origem ao IJ-R-Br, sendo que Bazon (2016), Costa, Komatsu e Bazon (2017) e Bazon, Costa e Komatsu (2018) contribuíram com estudos visando obter novas evidências de precisão e de validade do instrumento ao contexto brasileiro. Nesse conjunto de investigações, verificou-se que a consistência interna das escalas do IJ-R-Br, aferida por testereteste com intervalo de um mês e meio junto a 38 adolescentes não judicializados variou de 0,45 a 0,71 . Verificou ainda que a consistência interna aferida pelo método das metades junto a 2.328 adolescentes variou de 0,57 a 0,87 . Quanto à validade, as pontuações dos adolescentes judicializados e não judicializados diferiram em $76 \%$ das comparações realizadas para cada escala, por faixa etária de 13 a 18 anos, indicando que as medidas concorrem em um mesmo critério. Além disso, as escalas DS e IA do IJ-R-Br mostraram-se bastante sensíveis em classificar corretamente $75 \%$ e $80 \%$ dos adolescentes não judicializados e $79 \%$ e $81 \%$ dos adolescentes judicializados, respectivamente.

Tabela 4.4

Síntese das escalas do Inventário de Jesness

\section{Desadaptação Social (DS): 62 itens}

\section{Exemplos de itens}

15. É muito melhor não ter 22. Um tipo como eu, primeiro entra na briga e depois faz as perguntas; 33. Os policiais metem o nariz em muitas coisas que não é serviço deles. confiança em ninguém;

\section{Descrição}

Refere-se à dificuldade do indivíduo de respeitar as exigências da vida social, de se conformar às regras sociais. Indivíduos com altas pontuações tendem a apresentar sentimentos de infelicidade, aflição e inquietação. Por conta de seu mal-estar psicológico, são invadidos por sentimentos de hostilidade difíceis de controlar. Desconfiam de figuras de autoridade, culpabilizam os outros por seus próprios problemas e tendem a buscar atividades de risco, muitas vezes de modo impulsivo.

\section{Orientação de Valores (OV): 38 itens}

\section{Exemplos de itens}

5. Eu gosto muito de estar ligado ao mesmo grupo de amigos;

\section{Descrição}

Refere-se a crenças, pensamentos e atitudes associadas ao comportamento infracional. Os itens dessa escala referem-se a situações em que se enaltece o uso da força para resolver 
40. Vencer uma briga é a maior satisfação que existe; 71. Na minha vida nunca aconteceu uma grande coisa.

\section{Exemplos de itens}

8. Quando me criticam eu me sinto facilmente ferido; 39. Somente as crianças pequenas é que choram quando elas se machucam; 108. Um dia eu gostaria de dirigir um carro de corrida.

\section{Exemplos de itens}

74. Muitas pessoas falam de mim por trás;

99. É preciso ser alguém muito inteligente para ganhar de mim;

158. Eu acho que eu tenho alguma coisa que não funciona na minha cabeça.

\section{Exemplos de itens}

15. É muito melhor não ter confiança em ninguém;

57. Pouco me importa se as pessoas gostam ou não de problemas, se concebe que brigas e confusões são inevitáveis, que se valoriza um grupo de amigos próximos como forma de se proteger e se apresenta uma tendência a somatizar tensões internas.

\section{Imaturidade (IM): 29 itens}

\section{Descrição}

Refere-se à percepção do mundo, dos outros e de si mesmo de um modo que seria esperado em indivíduos mais novos. Dessa forma, uma pontuação alta remete à falta de acurácia para perceber e interpretar os estímulos ambientais que é adquirida com o avanço da idade, pelo acúmulo de experiências. Pontuações muito baixas, contudo, pode indicar pessimismo e cinismo acentuado. Este fator não tem relação direta com o envolvimento em atividades infracionais; ele é mais útil no momento da elaboração e implementação de um plano de intervenção dos adolescentes.

\section{Autismo (AU): 26 itens}

\section{Descrição}

Trata-se de uma avaliação irrealista de si mesmo, notadamente autocentrado/egocentrado. Os itens que compõem essa escala remetem a uma avaliação de si mesmo como autossuficiente, forte e esperto, ao mesmo tempo que outros itens revelam uma preocupação com algo errado na própria "cabeça". Por isso, uma pontuação alta nessa escala indica uma grande insegurança disfarçada de adequação, decorrente de alguma defasagem no desenvolvimento cognitivo e integrativo.

\section{Alienação (AL): 25 itens}

\section{Descrição}

Reflete uma atitude negativa, baseada na desconfiança e estranhamento em relação aos outros. Indivíduos que pontuam alto nessa escala tendem a ser céticos e críticos em relação ao outro, principalmente às figuras de autoridade, sobre as quais 
$\operatorname{mim}$;

135. As pessoas que tem autoridade geralmente estão contra mim. sustentam a crença de que são dominadoras, injustas e desleais. A dificuldade na interação com o outro favorece um modo de relação hostil.

\section{Agressividade Manifesta (AM): 31 itens}

\section{Exemplos de itens}

11. Quando alguém me manda fazer alguma coisa, eu tenho vontade de fazer o contrário;

38. Eu perco a paciência por coisas que não tem muita importância;

55. Quando eu tento ser um bom sujeito, sempre me acontece uma coisa ruim.

\section{Retraimento/Depressão (RT/DEP): 22 itens}

\section{Exemplos de itens}

47. Meu pai era muito ocupado para cuidar de $\operatorname{mim}$;

65. Não acredito que eu vou ter um grande sucesso na vida;

71. Na minha vida nunca aconteceu uma grande coisa.

\section{Exemplos de itens}

21. Eu me preocupo pelo que as outras pessoas pensam de mim; 25 . Eu fico sem jeito quando peço para

\section{Descrição}

Remete a conteúdos de natureza emocional associados à raiva e à agressividade. A consciência dessas emoções e sentimentos negativos e da reatividade a esses provoca desconforto nos indivíduos com alta pontuação. Esse desconforto decorre da preocupação e frustração de não conseguirem entender a si mesmos nem se sentirem bem consigo mesmos.

\section{Descrição}

Remete uma tendência em fugir e evitar interações sociais, provocando isolamento. Indivíduos com alta pontuação percebem-se mais tristes e deprimidos e podem apresentar baixa produtividade, desinteresse na atividades cotidianas e baixa autoestima. Apesar de buscarem o isolamento, o fato de ficarem sozinhos os fazem sentir-se mal compreendidos. Essa escala não tem relação direta com a delinquência.

\section{Ansiedade Social (AS): 20 itens}

\section{Descrição}

Os itens dessa escala apontam para uma vivência consciente de desconforto emocional atrelado à ansiedade nas relações interpessoais. Indivíduos que pontuam alto tendem a se sentir tensos nas relações sociais e interpessoais, percebendo-se 
alguém me fazer um favor; 35. Mesmo que eu não mostre, eu tenho medo de muitas coisas

\section{Exemplos de itens}

19. Eu nunca conto mentiras;

70. Não me importo quando alguém mexe comigo ou se diverte as minhas custas; 78. Eu gosto de todas as pessoas que eu conheço.

\section{Exemplos de itens}

90. Eu não me preocupo muito pelo que acontece; 107. Os pais e as mães implicam sempre com os jovens;

118. Falar com os meus pais é tão fácil como falar com os jovens da minha idade.

\section{Índice de Associabilidade (IA)}

\section{Descrição}

Os itens da escala DS contam positivamente para o IA. a delinquência.

\section{Repressão (REP): 14 itens} próprios sentimentos e emoções.

\section{Negação (NG): 19 itens} de conflitos familiares importantes. tímidos e muito sensíveis às críticas. Por esse motivo, evitam situações sociais e apresentam problemas de entrosamento com pares de idade. Essa escala também não tem relação direta com

Reflete a tendência em neutralizar ou reprimir da consciência os sentimentos e emoções negativas, como se tudo estivesse sempre bem. Indivíduos com alta pontuação nessa escala tendem a ser acríticos em relação a si e aos outros. Contudo, uma alta pontuação pode decorrer de outros dois motivos: o respondente mentiu ou apresenta dificuldades em nomear os

Remete a uma tendência em negar as próprias inadequações e infelicidades e os conflitos que possuem com os pais/responsáveis. Indivíduos com alta pontuação nessa escala relutam em tomar consciência de problemas e dificuldades do dia a dia. Uma pontuação muito baixa pode indicar a presença

O índice é resultado de uma combinação matemática das pontuações das escalas DS, OV, AU, AL, AM, RT/DEP, AS e REP. O IA é considerado a informação mais relevante para distinguir infratores de não infratores. Ele agrupa e sintetiza informações que indicam uma tendência para comportar-se de um modo que transgrida regras socialmente estabelecidas.

\section{Transtorno de Conduta (TC): 14 itens}


10. Às vezes eu tenho a impressão de que eu quero bater em alguém; 28. Às vezes, é bom conseguir enganar, "enrolar" alguém;

51. Eu já usei uma arma que poderia ter machucado alguém.
Representa uma série de afirmações que remetem a comportamentos de agredir pessoas e animais, destruir propriedades, furtar ou violar regras seriamente. Tais comportamentos estão associados aos critérios de classificação de TC proposta pelo DSM-IV.

\section{Transtorno Opositor Desafiador (TOD): 16 itens}

\section{Exemplos de itens}

44. Sinto muito prazer em irritar as outras pessoas; 126. Eu costumo discutir com pessoas mais velhas que acham que sabem de tudo;

131. Às vezes quando minha família me diz para eu não fazer alguma coisa, eu não escuto e faço o que eu quero.

\section{Descrição}

Representa comportamentos de desobediência ou conflitivo com figuras de autoridade. Os itens dessa escala estão associados aos critérios de classificação de TOD proposta pelo DSM-IV.

\section{Provas de desempenho executivo}

O Compêndio de Testes Neuripsicológicos (Strauss et al., 2006) apresenta dois testes de desempenho, visando avaliar as funções executivas, que são de rápida aplicação e foram incluídos como instrumentos do presente estudo: Teste de Stroop e Torres de Londres. Vale destacar que as Funções Executivas estão na base do autocontrole (variável de interesse no presente estudo) e englobam processos cognitivos e meta-cognitivos que permitem o indivíduo executar, controlar e regular seus próprios comportamentos, emoções, cognições e ações, permitindo, assim, implicar-se em comportamentos adaptativos, organizados e direcionados a alcançar objetivos (Dias \& Seabra, 2012). De acordo com o Centro sobre a 
Criança em Desenvolvimento de Harvard (2012), as funções executivas e a autorregulação são habilidades essenciais para obter sucesso acadêmico, no trabalho e na vida pessoal. Socialmente, os ganhos em bem-estar coletivo e individual se dão na redução dos gastos em saúde e nas taxas de criminalidade.

O desenvolvimento dessas funções acontece desde o nascimento, atinge um pico de crescimento dos 3 aos 6 anos e continua por algumas décadas, até se estabilizar por volta dos 30 anos. Segundo os estudos desse centro, esse desenvolvimento ocorre por meio das relações interpessoais, das atividades que os indivíduos têm oportunidade de se engajar e dos lugares em que vivem, aprendem e brincam. Experiências adversas - quando as crianças não têm suas necessidades atendidas pelas relações com adultos próximos e/ou pelo ambiente em que estão inseridas, ou pior, quando as experiências são fontes de estresse crônico, como nos casos de maus-tratos - podem prejudicar o desenvolvimento dessas funções (Center on the Developing Child, 2012).

Muitos casos clínicos e estudos de neuroimagem levaram os pesquisadores a atribuir ao lobo frontal um papel importante para o desempenho satisfatório em tarefas que exigem processamento executivo. Problemas com as funções executivas têm sido atribuídos a lesões ou mal funcionamento do lobo frontal. Embora nem todas as pessoas com lesão nesta região do cérebro apresentem prejuízos nas funções executivas, devido à neuroplasticidade.

Conforme pontuam Strauss, Sherman e Spreen (2006), o mal funcionamento das funções executivas pode se manifestar numa ampla classe de problemas cotidianos, como comportamento social inadequado; dificuldades em tomar decisões e fazer boas escolhas; dificuldades em seguir ou alterar planos; problemas com organização; distração; dificuldades em situações que exigem memória; e dificuldade em antecipar consequências. Ainda segundo esses autores, a disfunção executiva pode se refletir em testes de performance, nos quais indivíduos com algum tipo de mal funcionamento costumam iniciar as tarefas de um jeito ruim, apresentar mal planejamento e memória de trabalho ruim, dificuldade em corrigir erros ou aprender com a própria tarefa em questão.

\subsubsection{Teste de Stroop - Versão Victoria}

O teste Stroop foi desenvolvido por John Ridley Stroop em 1935 e tem sido amplamente utilizado como teste neuropsicológico para avaliar aspectos das funções executivas, como velocidade de processamento de informações, memória de trabalho, atenção 
seletiva, ativação semântica, flexibilidade cognitiva e controle inibitório (Macleod, 1991; Duncan, 2006; Strauss, Sherman, \& Spreen, 2006; Klein et al, 2010).

A versão Victoria utilizada no presente estudo foi escolhida devido a uma série de vantagens que Strauss e colegas (2006) apontam. A primeira é que ela é mais breve que outras versões, com apenas 24 itens em cada etapa, economizando tempo na aplicação (leva aproximadamente 5 minutos). Além disso, as evidências de pesquisas apontam que versões breves devem ser preferidas quando se trata de identificar indivíduos que possuem dificuldades com a tarefa (Strauss et al., 2006). Em um teste como o Stroop, também não é desejável prolongar a aplicação para que os participantes não aprendam sobre o próprio teste durante a própria execução da tarefa. Por fim, a versão Victoria é de domínio público, podendo ser utilizada ou modificada por qualquer pessoa.

O Teste de Stroop Victoria (TSV) é composto por três cartões com estímulos impressos nas cores verde, vermelho, azul e amarelo, como mostra a Figura 4.1. O primeiro cartão possui apenas retângulos coloridos com uma das 4 cores. $\mathrm{O}$ segundo cartão possui palavras neutras (Cada, Nunca, Tudo e Nada) pintadas com uma das quatro cores, sendo que as cores permanecem sempre na mesma posição. O terceiro cartão possui palavras conflitantes (nome de cores) pintadas com uma das quatro cores, sendo que nunca coincide de a palavra estar colorida com a cor que ela representa.

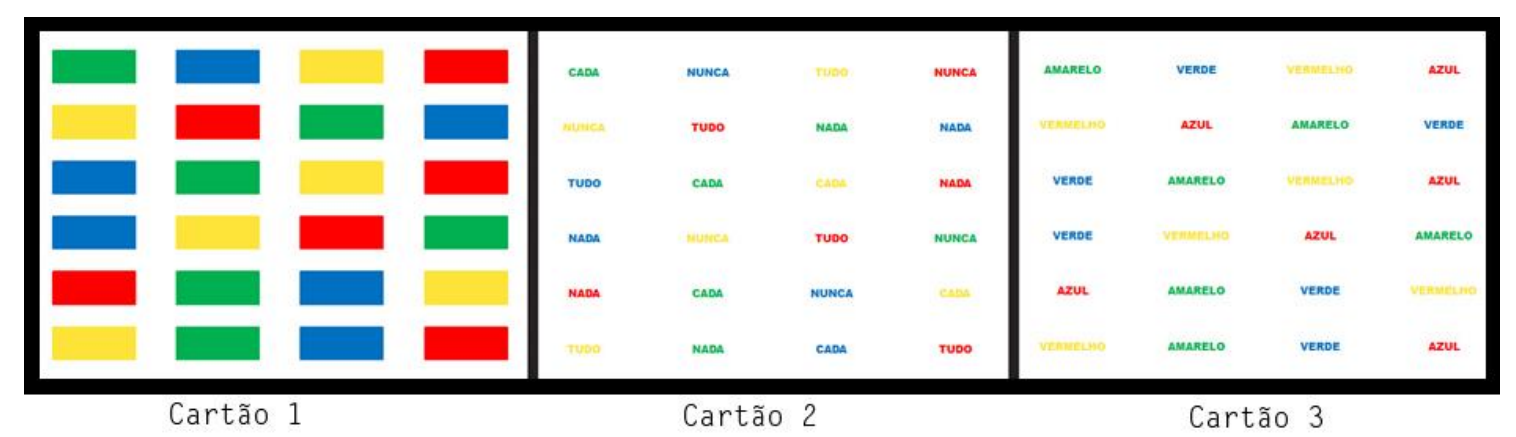

Figura 4.1. Cartões do Teste de Stroop Victoria (Fonte: autor)

A tarefa do respondente é nomear as cores dos retângulos e das palavras, linha por linha, da esquerda para a direita, o mais rápido possível, ignorando o conteúdo das palavras. No terceiro cartão, observa-se o efeito Stroop, caracterizado pela redução da velocidade na nomeação das cores e eventuais erros de nomeação. Sendo assim, utiliza-se como medida o tempo de execução e a quantidade de erros em cada etapa. Autocorreções espontâneas são pontuadas como corretas. Ressalta-se que o teste de Stroop não pode ser aplicado em 
indivíduos analfabetos ou com habilidade de leitura prejudicada ao ponto de não conseguirem ler as palavras das cores fluentemente.

Os dados normativos do TSV foram construídos com base em 272 canadenses de 18 a 94 anos. Para faixa de 18-39 anos, a média do tempo para completar a tarefa foi de 11s (DP = 2,5), 13s (DP = 2,9) e 22,1s (DP = 7,2) para os cartões I, II e III, respectivamente; e a média do número de erros para o cartão 3 foi de $2(\mathrm{DP}=0,6)$ (Strauss et al., 2006). No Brasil, os dados normativos para jovens de 18 a 21 anos de escolas públicas apontam média de tempo de $17 \mathrm{~s}(\mathrm{DP}=2,7), 19,2 \mathrm{~s}(\mathrm{DP}=3,2)$ e 27,2s $(\mathrm{DP}=5,5)$ e número médio de erros de 0 (DP = $0), 0,15(\mathrm{DP}=0,5)$ e $0,5(\mathrm{DP}=0,8)$ para os cartões I, II e III, respectivamente (Komatsu, Santos \& Bazon, 2019).

\subsubsection{Torres de Londres (TOL)}

O teste TOL foi desenvolvido por Shallice (1982) para avaliar o planejamento e as habilidades de resolução de problemas em pacientes com prejuízos no lobo frontal. Este teste consiste em apresentar ao participante três torres-modelo com argolas coloridas distribuídas em cada uma delas, solicitando que o mesmo reproduza, em outras três torres cujas argolas estão em uma posição inicial diferente, a mesma posição das argolas das torres-modelo (Figura 4.2). O participante só pode mover uma argola por vez (a que está acima das demais, em cada uma das torres), sendo-lhe solicitado que pense antes de começar a mexer as argolas. Há diversas versões do TOL com diferentes números de baterias. A versão utilizada no presente estudo foi a de Phillips (1999), na qual o respondente precisa completar oito modelos de torres diferentes.
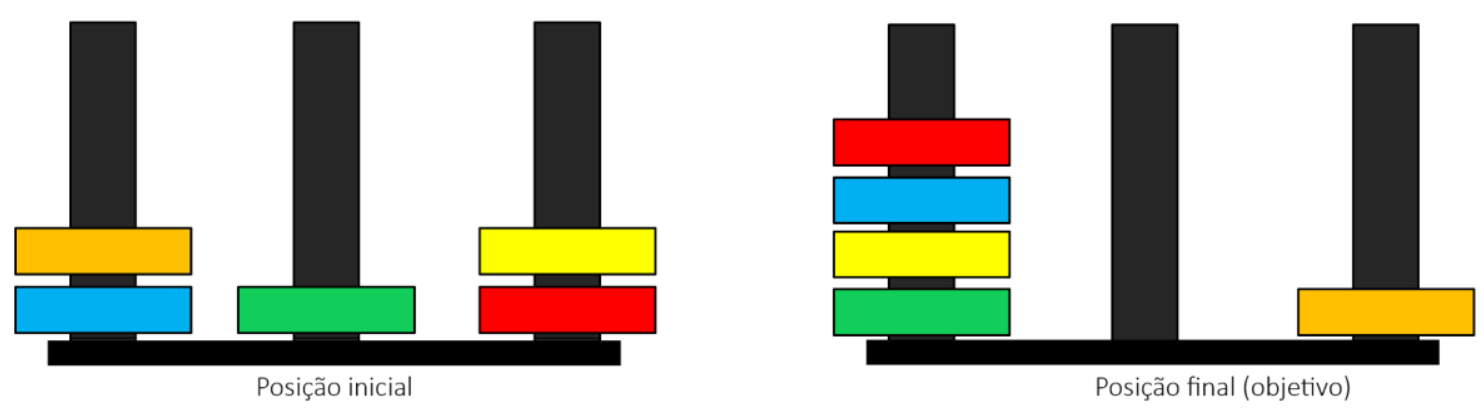

Figura 4.2. Teste das Torres de Londres. O participante deve movimentar, uma a uma, as argolas (ou blocos) das torres da posição inicial até que as torres fiquem iguais às torres da posição final. (fonte: autor) 
Neste teste, é contabilizado o tempo que o participante leva para planejar seus movimentos (tempo que leva para realizar o primeiro movimento), o tempo até completar a tarefa e o número total de movimentos até obter o resultado correto. Shallice (1982) encontrou que indivíduos que demoram mais tempo para começar a resolver e aqueles que realizam mais movimentos até chegar no resultado esperado são os que possuem mais prejuízos no lobo frontal.

A literatura tem mostrado a relação do TOL com habilidades de raciocínio e pensamento abstrato (Bugg et al., 2006), inteligência verbal (Unterrainer et al., 2004), inibição de impulso (Luciana et al., 2009) e como evidência para aferição do funcionamento das funções executivas do lobo frontal (Sylvers Ryan, Alden \& Brennan, 2009). O Teste das Torres de Londres também tem sido usado em amostras clínicas de adolescentes infratores. Veneziano, Veneziano, LeGrand e Richards (2004) encontraram que tanto adolescentes infratores sexuais quanto infratores implicados em outros tipos de delitos (não sexuais) necessitaram em média 10 movimentos a mais do que a população normativa, demonstrando pior performance. Além disso, os infratores iniciavam a tarefa cerca de 20 segundos antes que a população normativa, tempo de planejamento significativamente menor. Pham, Vanderstukken, Philippot e Vanderlinden (2003), dividiram uma amostra de 36 infratores de acordo com a pontuação no Psychopathy Checklist-Revised (PCL-R) e compararam o desempenho dos dois grupos na Torre de Londres. O grupo com maior pontuação no PCL-R, chamados de "com traços de psicopatia", apresentou significativamente mais movimentos que o grupo que pontuou menos. No Brasil, os dados normativos para jovens de 18 a 21 anos de escolas públicas apontam média de movimentos de $5(\mathrm{DP}=2,1), 11,2(\mathrm{DP}=3,3), 7,6(\mathrm{DP}=$ 3,7), $10(\mathrm{DP}=3,1), 6,5(\mathrm{DP}=2,3), 12$, ( $\mathrm{DP}=3,5), 9,7(\mathrm{DP}=1,6), 11,9(\mathrm{DP}=2,6)($ Komatsu, Santos \& Bazon, 2019). 


\subsubsection{Procedimento de coleta de dados}

Para a coleta de dados no $\mathrm{T} 1$, os adolescentes foram recrutados em duas Organizações Não-Governamentais (ONGs) prestadoras do serviço de Liberdade Assistida (n = 46), no município de Ribeirão Preto - SP, e em uma das unidades de Internação da Fundação CASA $(n=84)$, também sediada no município de Ribeirão Preto - SP, mediante autorização destas instituições, autorização dos pais/responsáveis, por meio da assinatura do Termo de Consentimento Livre e Esclarecido, e do próprio aceite dos participantes, manifesto em Termo de Assentimento. Tanto as instituições quanto os participantes e seus responsáveis foram informados quanto ao objetivo, método e aspectos éticos do trabalho, de modo que a coleta de dados junto aos adolescentes só foi iniciada quando todas as questões relativas à pesquisa estavam esclarecidas.

A coleta de dados se deu de forma individual em uma sala reservada na própria instituição onde os adolescentes foram recrutados. Nesta etapa da pesquisa (T1), foram aplicados os instrumentos QJC e IJ-R-Br, na forma de entrevista. O pesquisador leu as perguntas/itens dos instrumentos e assinalou as respostas dadas pelos adolescentes em folhas do Questionário e do Inventário. Conforme o já mencionado, essas entrevistas ocorreram entre os meses de janeiro e agosto de 2015.

$\mathrm{Na}$ segunda etapa da pesquisa (T2), passados em média 18 meses do primeiro levantamento, de posse das informações para contatar os adolescentes em suas residências/comunidades - telefone(s) e/ou o endereço-, passou-se a se buscar pelos mesmos de forma a poder convidá-los para colaborarem com a pesquisa no segundo levantamento. Nesta etapa (T2), conforme o já mencionado, 81 adolescentes foram localizados, sendo que três deles, após o convite para a participação no segundo levantamento, decidiram não aceitarão participar da pesquisa. Os 78 adolescentes remanescentes, após esclarecimento do objetivo, do método e dos aspectos éticos da pesquisa, foram visitados e entrevistados em suas casas. Nesta segunda etapa, os adolescentes foram submetidos aos mesmos instrumentos da primeira etapa (também aplicados na forma de entrevista), assim como ao Teste de Stroop Versão Victoria e ao Teste da Torre de Londres. Conforme o já mencionado, esta segunda etapa se desenrolou entre os meses junho de 2016 e março de 2017.

Adicionalmente, empreendeu-se procedimentos para levantar e registrar dados sobre a delinquência oficial dos adolescentes envolvidos na pesquisa, por meio de análise documental, de modo a compor a variável "Histórico de Infrações". O Histórico de Infrações (delitos oficialmente reconhecidos e atribuídos ao adolescente) em função das quais teriam 
sido apreendidos e processados durante toda a adolescência foi levantado junto ao histórico de processos dos adolescentes $(\mathrm{n}=118)$, arquivados no Núcleo de Atendimento Integrado (NAI) ${ }^{9}$ da comarca de Ribeirão Preto - SP, em março de 2017, uma vez finalizada a coleta de dados junto aos próprios adolescentes, no T2, cerca de 18 meses após a coleta realizada no T1. Foram registrados os tipos delitos e as datas em que os mesmos haviam ocorrido. Com este procedimento, obteve-se a lista de todos os delitos pelos quais os adolescentes pesquisados haviam sido apreendidos e processados na Justiça Juvenil. Entre os 19 tipos delitos identificados neste levantamento, seis foram considerados violentos por se enquadrarem na definição adotada por este estudo: ameaça, lesão corporal, roubo, sequestro, latrocínio e homicídio.

A título de síntese, a Figura 4.3 esquematiza os procedimentos de coleta de dados juntos aos adolescentes investigados no $\mathrm{T} 1$ e no $\mathrm{T} 2$, indicando os instrumentos empregados.

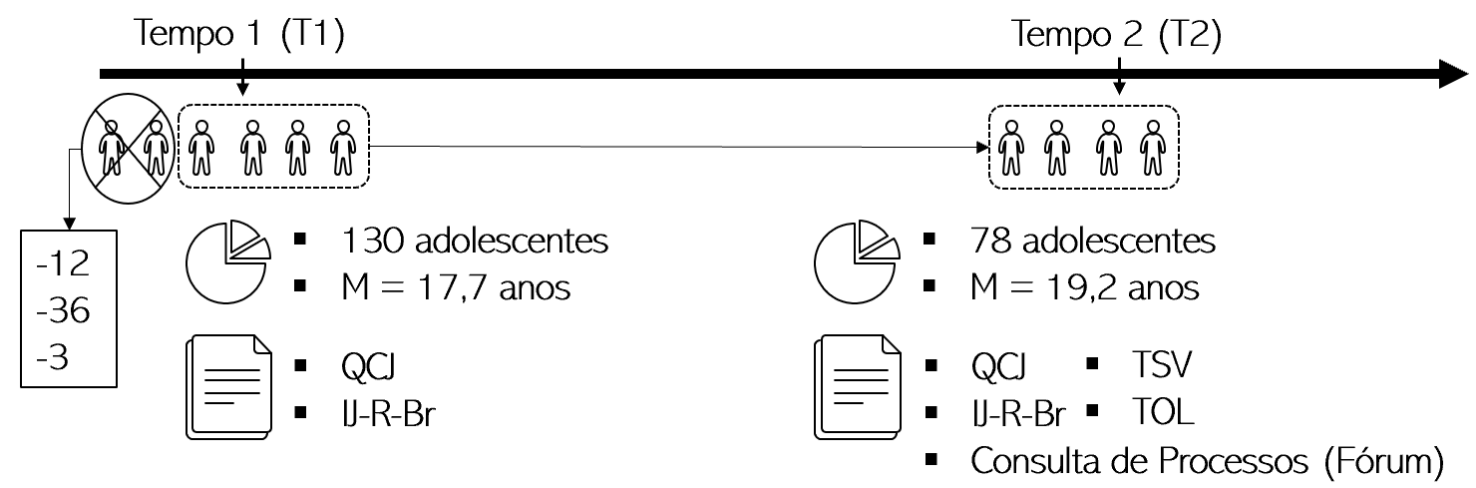

Figura 4.3. Adolescentes que participaram em cada etapa da pesquisa e instrumentos empregados na coleta de dados em cada etapa (Fonte: Autor)

\footnotetext{
${ }^{9}$ A título de esclarecimento, o NAI é um serviço que dá cumprimento ao Artigo 88 do Estatuto da Criança e do Adolescente (ACA) no seu inciso V. O NAI foi concebido para fomentar uma política de integração operacional de órgãos do Judiciário, Ministério Público, Defensoria, Segurança Pública e Assistência Social, preferencialmente em um mesmo local, para efeito de agilização do atendimento inicial ao adolescente a quem se atribua autoria de ato infracional. Nesse sentido, este serviço detém dados relativos a Boletins de Ocorrência Policial, nos quais há adolescentes envolvidos, e a Processos originados do fato de terem sido representados devido ao cometimento de uma infração.
} 


\subsubsection{Procedimento de análise de dados}

Todas as informações coletadas na primeira e na segunda etapas da pesquisa foram armazenadas em um banco de dados digital, distinguindo as informações referentes a cada tempo da coleta. Em seguida, análises descritivas foram realizadas com o objetivo de sintetizar as informações referentes aos dados coletados no T1 e no T2, calculando-se as médias, desvios-padrão, medianas, mínimos e máximos das variáveis quantitativas e as frequências das variáveis categóricas.

No T1, os adolescentes foram designados como "violentos" ou "não violentos" a partir de seus históricos comportamentais. Para tal, utilizou-se dois critérios de classificação distintos: 1) tendo como referência o autorrelato de delitos no decorrer do último ano; 2) tendo como referência o dado sobre ao menos um delito violento no histórico oficial de delitos (atinente aos boletins de ocorrência). Pelo primeiro método, 40 adolescentes foram classificados no Grupo Não Violento (GNV) e 78 adolescentes foram classificados no Grupo Violento (GV). Pelo segundo método, o GNV reuniu 52 adolescentes e o GV, 66. Em seguida, as médias dos dois grupos foram comparadas em relação aos parâmetros de engajamento infracional fornecidos pelos comportamentos delituosos autorrevelados (idade de início, diversidade e frequência), às pontuações nas escalas do IJ-R-Br e nas medidas dos fatores de risco e de proteção do QJC. Como as medidas não apresentaram grande assimetria e grande curtose, e pelo fato de o teste $\mathrm{t}$ apresentar-se robusto com amostras suficientemente grandes (Lumley, Diehr, Emerson, \& Chen, 2002), optou-se pelo uso do teste t para amostras independentes como método de análise comparativa entre os grupos. Para corrigir o viés da significância devido às múltiplas comparações, foi empregado o procedimento de BenjaminiHochbergd (1995) em todas as comparações.

O mesmo procedimento de comparação dos grupos foi realizado com os dados obtidos no T2. Adicionalmente, nessa etapa, os escores dos grupos GNV e GV no QCJ foram transformados em escore-z com base nos parâmetros da população normativa do instrumento, com vistas a visualizar o quanto a pontuação dos grupos diferiam entre si e também o quanto desviavam de adolescentes não infratores da mesma faixa etária.

Com fins de identificar mudanças psicossociais associadas a mudanças de trajetórias, foram identificados os indivíduos que passaram de Violentos no T1 para Não violentos no T2 (V-NV) e de Não Violentos no T1 para Violentos no T2 (NV-V). O teste Wilcoxon foi utilizado para identificar alterações significativas entre os próprios indivíduos nas escalas do 
IJ-R-Br e nos construtos avaliados pelo QCJ, com vistas a identificar possíveis explicações para a mudança no comportamento delituoso, de acordo com dado autorrevelado.

Por fim, foram realizadas duas regressões logísticas utilizando como variáveis independentes as diversas escalas e construtos mensurados pelo IJ-R-Br e pelo QCJ, considerados potenciais risco ou proteção associados à variável dependente em foco, no caso, a conduta delituosa violenta autorrevelada no T2. O peso dessas variáveis foi atribuído pela razão de chances (Odds Ratio), de modo a obter um modelo preditivo testável em uma amostra que não participou da construção deste modelo.

Os modelos foram obtidos por dois métodos distintos de selecionar as variáveis relevantes: Forward Conditional e Insert. O primeiro consistiu em inserir todas as variáveis de risco e de proteção do IJ-R-Br e do QCJ, mensuradas no T1, como preditores do comportamento violentos e, por procedimentos iterativos, selecionar apenas as variáveis consideradas relevantes para o modelo. O segundo modelo foi composto por variáveis relevantes selecionadas anteriormente pelo teste de qui-quadrado, no qual as variáveis que separavam maiores proporções de adolescentes violentos em um grupo e de adolescentes não violentos em outro foram utilizadas para compor o modelo.

Para a construção dos modelos foram selecionados aleatoriamente 55 adolescentes (70\% da amostra) e, em seguida, ambos foram testados, seguindo a equação descrita por Agresti (2012, p. 163), nos 23 (30\%) dos adolescentes que não participaram da construção dos modelos. Considerou-se como provável envolvimento em delito violento a probabilidade maior que 0,50 , e o provável não envolvimento foi aferido pela probabilidade menor ou igual a 0,50 . 


\subsection{Resultados}

Destacam-se como primeiros resultados a frequência de infrações (delitos oficiais) pelos quais os adolescentes do presente estudo haviam sido apreendidos até o momento em que a coleta desta informação foi realizada, em março de 2017, após se encerrarem as coletas do T2. A Tabela 4.5 mostra que delitos envolvendo substâncias ilícitas, seja na forma de tráfico, seja na de posse para consumo pessoal, correspondem à quase metade do total das infrações registradas (47,7\%). Já os delitos violentos identificados (Roubo, Homicídio, Lesões Corporais, Ameaça, Latrocínio e Sequestro) somam mais de um quinto das infrações $(22,5 \%)$.

Tabela 4.5

Frequência de delitos oficiais atribuídos aos adolescentes $(n=118)$

\begin{tabular}{lcc}
\hline Delito & Freq. & $\mathbf{\%}$ \\
\hline Tráfico de Drogas & 166 & 43,5 \\
Roubo & $\mathbf{7 7}$ & $\mathbf{2 0 , 2}$ \\
Furto & 34 & 8,9 \\
Receptação & 33 & 8,6 \\
Posse de Drogas para Consumo Pessoal & 16 & 4,2 \\
Adulteração de Sinal Identificador de Veículo Automotor & 7 & 1,8 \\
Desacato & 4 & 1,0 \\
Homicídio & $\mathbf{4}$ & $\mathbf{1 , 0}$ \\
Lesões Corporais & $\mathbf{4}$ & $\mathbf{1 , 0}$ \\
Porte de Arma de Fogo & 4 & 1,0 \\
Fraude & 3 & 0,8 \\
Ameaça & $\mathbf{2}$ & $\mathbf{0 , 5}$ \\
Fuga de Pessoa Presa & 2 & 0,5 \\
Latrocínio & $\mathbf{2}$ & $\mathbf{0 , 5}$ \\
Dano Qualificado & 1 & 0,3 \\
Estelionato & 1 & 0,3 \\
Incêndio & 1 & 0,3 \\
Resistência & 1 & 0,3 \\
Sequestro e Cárcere Privado & $\mathbf{1}$ & $\mathbf{0 , 3}$ \\
Infração não especificada & 19 & 5,0 \\
\hline Total & 382 & 100 \\
\hline Nota
\end{tabular}

Nota: em negrito, os delitos caracterizados como violentos por envolver violência interpessoal

Condizente com os dados oficiais, as informações fornecidas pelos próprios adolescentes, por meio das respostas ao Questionário (QCJ), mostraram que os delitos envolvendo substâncias psicoativas ilícitas, especificamente o tráfico de drogas, teria sido de fato o delito praticado pela maior parte dos adolescentes (87\% no T1 e 95\% no T2), 
sendo também o ato praticado com maior frequência (39\% do total dos atos no T1 e $64 \%$ do total dos atos no T2), como mostram as tabelas 4.6 e 4.7, respectivamente.

É também interessante notar que a maioria dos adolescentes revelou já ter portado uma arma de fogo, sendo que a frequência com a qual o fizeram, de acordo com o próprio relato foi de $19 \%$ e $14 \%$ do total de delitos reportados nos Tempos 1 e 2, respectivamente. Esse dado chama atenção porque, embora o Porte de Arma de Fogo não seja um delito violento em si, ele é uma conduta de risco para outros delitos potencialmente violentos.

Tabela 4.6

Quantidade de adolescentes que revelaram cada comportamento delituoso investigado pelo QCJ (Autorrevelados)

\begin{tabular}{|c|c|c|c|c|}
\hline \multirow[b]{2}{*}{ Delito } & \multicolumn{2}{|c|}{$\begin{array}{c}\text { T1 } \\
(n=118)\end{array}$} & \multicolumn{2}{|c|}{$\begin{array}{c}\text { T2 } \\
(n=78)\end{array}$} \\
\hline & Freq. & $\%$ & Freq. & $\%$ \\
\hline Tráfico de Drogas & 103 & $87 \%$ & 73 & $94 \%$ \\
\hline Receptação & 87 & $74 \%$ & 61 & $78 \%$ \\
\hline Porte de Arma de Fogo & 75 & $64 \%$ & 45 & $58 \%$ \\
\hline Furto de veículo & 67 & $57 \%$ & 41 & $53 \%$ \\
\hline Roubo & 64 & $54 \%$ & 40 & $51 \%$ \\
\hline Dano & 61 & $52 \%$ & 60 & $77 \%$ \\
\hline Furto em estabelecimento comercial & 53 & $45 \%$ & 50 & $64 \%$ \\
\hline Furto de pessoas & 52 & $44 \%$ & 39 & $50 \%$ \\
\hline Rixa & 39 & $\mathbf{3 3 \%}$ & 37 & $47 \%$ \\
\hline Lesão corporal com uso de instrumento & 39 & $33 \%$ & 26 & $33 \%$ \\
\hline Maus-tratos de animais & 33 & $28 \%$ & 13 & $17 \%$ \\
\hline Furto em interior de veículo & 27 & $23 \%$ & 13 & $17 \%$ \\
\hline Lesão corporal & 13 & $11 \%$ & 4 & $5 \%$ \\
\hline
\end{tabular}

Os delitos violentos investigados (Lesão corporal, Lesão corporal com uso de instrumento e Roubo) somaram 13\% do total de delitos revelados no T1 e $8 \%$ no T2 (Tabela 4.7), porcentagens menores que aquelas aferidas a partir dos dados do Sistema de Justiça Juvenil, como mostrado na tabela 4.5. 
Tabela 4.7

Quantidade de adolescentes e frequência de comportamentos delituosos investigados pelo QCJ no último ano (Autorrevelados)

\begin{tabular}{|c|c|c|c|c|c|c|}
\hline \multirow[b]{2}{*}{ Delito } & \multicolumn{3}{|c|}{$\begin{array}{c}\text { T1 } \\
(n=118)\end{array}$} & \multicolumn{3}{|c|}{$\begin{array}{c}\text { T2 } \\
(n=78)\end{array}$} \\
\hline & Prev. & Freq. & $\%$ & Prev. & Freq. & $\%$ \\
\hline Tráfico de Drogas & 61 & 2491 & $40 \%$ & 14 & 1775 & $64 \%$ \\
\hline Porte de Arma de Fogo & 47 & 1175 & $19 \%$ & 23 & 392 & $14 \%$ \\
\hline Receptação & 58 & 1009 & $16 \%$ & 25 & 140 & $5 \%$ \\
\hline Roubo & 40 & 666 & $11 \%$ & 27 & 186 & $7 \%$ \\
\hline Furto de veículo & 37 & 288 & $5 \%$ & 19 & 59 & $2 \%$ \\
\hline Furto de pessoas & 21 & 303 & $5 \%$ & 11 & 94 & $3 \%$ \\
\hline Dano & 19 & 98 & $2 \%$ & 17 & 30 & $1 \%$ \\
\hline Furto em estabelecimento comercial & 16 & 68 & $1 \%$ & 27 & 43 & $2 \%$ \\
\hline Lesão corporal com uso de instrumento & 16 & 44 & $1 \%$ & 10 & 30 & $1 \%$ \\
\hline Lesão corporal & 12 & 47 & $1 \%$ & 4 & 5 & $\mathbf{0 \%}$ \\
\hline Maus-tratos de animais & 9 & 41 & $1 \%$ & 4 & 5 & $0 \%$ \\
\hline Furto em interior de veículo & 8 & 32 & $1 \%$ & 2 & 3 & $0 \%$ \\
\hline Rixa & 7 & 11 & $0 \%$ & 8 & 11 & $0 \%$ \\
\hline
\end{tabular}

Prev. $=$ prevalência de adolescentes que referiram o delito; Freq. = soma de vezes que o delito foi realizado no último ano; \%: frequência relativa.

A tabela 4.8 mostra que idade em que o primeiro delito foi cometido variou de 11,6 anos no T1 para 10,9 no T2. Essa variação, que teoricamente não deveria ocorrer dado que a idade entre o T1 e T2 não poderia mudar, tampouco ser maior no T1, é certamente decorrência do fato de a idade média ser recalculada com base nos participantes que integram a amostra do T2, lembrando que houve a perda de 40 participantes, de um tempo a outro, assim como das imprecisões nas informações oferecidas pelos próprios participantes, nos dois momentos da coleta, considerando os limites mnemônicos.

A frequência de delitos que os adolescentes teriam realizados no decorrer do último ano apresenta grande variabilidade ( $\mathrm{DP}=85,3$ e Máx $=585$, no T1), denotando a presença de outliers que cometem uma quantidade de delitos muito maior que a maioria dos participantes, muito provavelmente devido à elevada frequência com a qual delitos como Tráfico de Drogas, Dano e Receptação são reportados. A frequência de delitos violentos também apresenta importante amplitude no T1; esta se mostra, contudo, menor e mais estável no T2. 
Tabela 4.8

Medidas de tendência central dos comportamentos delituosos autorrevelados

\section{DP Mdn Mín Máx}

\section{$\mathrm{T1}(\mathrm{n}=118)$}

Delitos - Idade da primeira vez

Delitos - Freq. Último ano

11,6

53,7

2,4

12

$\begin{array}{ll}6 & 17\end{array}$

Delitos - Diversidade

5,9

85,3

26,5

$0 \quad 585$

Delitos Violentos - Diversidade

1,3

3,6

6

$0 \quad 13$

Delitos Violentos - Freq. Último Ano

$6,5 \quad 21,3$

$0 \quad 4$

\section{T2 $(\mathbf{n}=78)$}

Delitos - Idade da primeira vez

Delitos - Freq. Último ano

10,9

3,5

0

$0 \quad 151$

Delitos - Diversidade

38,4

3,5

12

$6 \quad 16$

Delitos Violentos - Diversidade

6,9

58,1

11

$0 \quad 325$

Delitos Violentos - Freq. Último Ano

$1,2 \quad 1,1$

6,5

113

$2,8 \quad 5,8$

6,1

$\begin{array}{ll}0 & 4\end{array}$

.

Na tabela 4.9 são apresentadas as quantidades de adolescentes que relataram cada um dos comportamentos de risco referente ao uso de substâncias psicoativas. Nota-se que quase todos os adolescentes já tinham feito uso de álcool (90\%) ou de alguma droga ilícita (92\%) no T1. No T2, todos os jovens já haviam ingerido álcool e quase todos (96\%) consumido alguma droga ilícita ao menos uma vez na vida. Apesar do fato de que no T2 grande parte desses jovens já havia atingido a maioridade - idade legal para consumir álcool - destaca-se que mais da metade $(51 \%)$ informou consumir com regularidade - ao menos uma vez por semana; e aproximadamente um a cada seis jovens (17\%) referiram fazer uso semanal de maconha, no $\mathrm{T} 2$.

Tabela 4.9

Frequência de adolescentes por categoria de uso de substâncias

\begin{tabular}{|c|c|c|c|c|}
\hline & \multicolumn{2}{|c|}{$\begin{array}{c}\text { T1 } \\
(\mathrm{n}=118)\end{array}$} & \multicolumn{2}{|c|}{$\begin{array}{c}\text { T2 } \\
(n=78)\end{array}$} \\
\hline & Freq. & $\%$ & Freq. & $\%$ \\
\hline Consumo de álcool (na vida) & 106 & 90 & 78 & 100 \\
\hline Consumo semanal de álcool & 45 & 38 & 40 & 51 \\
\hline Consumo de drogas (na vida) & 109 & 92 & 75 & 96 \\
\hline Consumo semanal de maconha & 16 & 14 & 13 & 17 \\
\hline Consumo semanal de outras drogas & 2 & 2 & 0 & 0 \\
\hline
\end{tabular}


A tabela 4.10 mostra os escores médios dos adolescentes nas escalas do QCJ. É importante lembrar que no caso dos fatores de risco como, por exemplo, Impulsividade ou Atitude Violenta, cada escore denota a presença de um indicador de risco, ou seja, quanto maior a pontuação, maior o risco; no caso de fatores de proteção como, por exemplo, Vínculo Escolar, cada escore representa um indicador de proteção, ou seja, um elemento a mais na constituição de uma ligação forte com a escola ou com a educação, tendo por base uma crença que essas instituições podem proporcionar mudanças positivas na vida.

Tabela 4.10

Médias, desvios-padrão, medianas, mínimos e máximos dos adolescentes na pontuação das escalas do QCJ no T1 e no T2

\begin{tabular}{|c|c|c|c|c|c|c|c|c|c|c|}
\hline \multirow[b]{2}{*}{ Escala do QCJ } & \multicolumn{5}{|c|}{ Tempo $1(n=118)$} & \multicolumn{5}{|c|}{ Tempo $2(n=78)$} \\
\hline & $\mathbf{M}$ & DP & Md & Mn & $\mathbf{M x}$ & $\mathbf{M}$ & DP & Md & Mn & $\mathbf{M x}$ \\
\hline Impulsividade & 1,9 & 1,3 & 2 & 0 & 5 & 1,8 & 1,4 & 2 & 0 & 5 \\
\hline Valores antissociais & 1,5 & 2,0 & 1 & 0 & 8 & 1,3 & 1,9 & 0 & 0 & 8 \\
\hline Atitude violenta & 1,6 & 1,2 & 2 & 0 & 4 & 1,5 & 1,2 & 1 & 0 & 4 \\
\hline $\begin{array}{l}\text { Oposição a figuras de } \\
\text { autoridade }\end{array}$ & 1,5 & 1,0 & 2 & 0 & 3 & 1,4 & 1,0 & 2 & 0 & 3 \\
\hline $\begin{array}{l}\text { Problemas com a polícia e } \\
\text { a justiça }\end{array}$ & 6,3 & 1,9 & 7 & 2 & 8 & 6,0 & 1,9 & 6 & 2 & 8 \\
\hline Investimento familiar & 0,4 & 0,6 & 0 & 0 & 2 & 0,4 & 0,6 & 0 & 0 & 2 \\
\hline Apego parental & 2,4 & 1,2 & 3 & 0 & 4 & 2,5 & 1,2 & 3 & 0 & 4 \\
\hline Supervisão parental & 3,3 & 1,1 & 3 & 0 & 5 & 3,3 & 1,1 & 4 & 0 & 5 \\
\hline Escola desorganizada & 2,4 & 1,6 & 2,5 & 0 & 5 & 2,3 & 1,6 & 2 & 0 & 5 \\
\hline $\begin{array}{l}\text { Estresse em contexto } \\
\text { escolar }\end{array}$ & 2,2 & 2,1 & 2 & 0 & 8 & 2,2 & 2,0 & 2 & 0 & 7 \\
\hline Vínculo escolar & 1,4 & 0,7 & 2 & 0 & 2 & 1,4 & 0,7 & 2 & 0 & 2 \\
\hline $\begin{array}{l}\text { Valores positivos frente à } \\
\text { escola e aos estudos }\end{array}$ & 2,4 & 0,7 & 3 & 0 & 3 & 2,4 & 0,8 & 3 & 0 & 3 \\
\hline $\begin{array}{l}\text { Bom desempenho } \\
\text { acadêmico }\end{array}$ & 0,3 & 0,5 & 0 & 0 & 1 & 0,2 & 0,4 & 0 & 0 & 1 \\
\hline $\begin{array}{l}\text { Prob. de comp. em } \\
\text { contexto escolar }\end{array}$ & 3,8 & 0,9 & 4 & 1 & 5 & 3,8 & 0,9 & 4 & 1 & 5 \\
\hline Atraso escolar & 2,2 & 1,1 & 2 & 0 & 5 & 2,2 & 1,2 & 2 & 0 & 5 \\
\hline Rotina desestruturada & 2,9 & 1,6 & 3 & 0 & 7 & 2,6 & 1,4 & 3 & 0 & 6 \\
\hline Atividades pró-sociais & 1,0 & 0,9 & 1 & 0 & 4 & 1,0 & 0,9 & 1 & 0 & 4 \\
\hline Pares infratores & 0,8 & 1,7 & 0 & 0 & 10 & 0,8 & 1,8 & 0 & 0 & 10 \\
\hline Bairro deteriorado & 1,1 & 1,0 & 1 & 0 & 3 & 1,0 & 1,0 & 1 & 0 & 3 \\
\hline $\begin{array}{l}\text { Percepção de violência e } \\
\text { criminalidade no bairro }\end{array}$ & 2,3 & 1,4 & 3 & 0 & 5 & 2,3 & 1,4 & 2,5 & 0 & 5 \\
\hline $\begin{array}{l}\text { Controle informal no } \\
\text { bairro }\end{array}$ & 1,5 & 0,7 & 2 & 0 & 2 & 1,6 & 0,6 & 2 & 0 & 2 \\
\hline Controle formal no bairro & 1,1 & 0,9 & 1 & 0 & 2 & 1,1 & 0,9 & 1 & 0 & 2 \\
\hline
\end{tabular}


Apoio social Idade do Primeiro Delito

Diversidade de delitos

Freq. de delitos (último

ano)

Diversidade delitos

violentos

Freq. delitos violentos (último ano)
$2,1 \quad 1,1 \quad 2 \quad 0$

$12,4 \quad 2,0 \quad 13 \quad 7$

$3,8 \quad 3,4 \quad 3,5 \quad 0$

$25,2 \quad 68,0 \quad 2$

$0,7 \quad 0,8 \quad 0$

$2,0 \quad 4,9$

$\begin{array}{cccccc}3 & 1,9 & 1,1 & 2 & 0 & 3 \\ 17 & 12,2 & 2,0 & 13 & 7 & 16 \\ 11 & 5,7 & 2,5 & 5 & 0 & 11\end{array}$

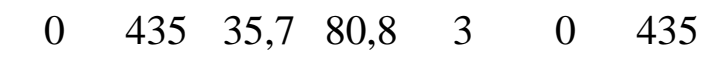

M: média; DP: desvio-padrão; Md: mediana; Mn: mínimo; Mx: máximo.

A tabela 4.11 apresenta as medidas centrais normatizadas dos escores obtidos pelos participantes nas escalas do Inventário de Jesness (IJ-R-Br). No T1, com exceção do verificado em IA, escala na qual o escore médio do grupo situa-se acima de 60, ou seja, acima de um desvio-padrão, em todas as outras subescalas do instrumento a amostra obteve escores médios dentro de um desvio-padrão; assim, em média, estariam dentro do esperado para sua idade. Todavia, as amplitudes das pontuações, aferidas pelos valores Mínimos e Máximos, indicam que em todas as escalas há pelo menos um adolescente abaixo e um adolescente acima dos desvios padrões esperado para a idade (entre 40 e 60). A mediana mostra que em algumas escalas, como DS, AL e IA, mais da metade da amostra está acima de um desvio. Esclarece-se que para esta descrição, trabalhou-se com dados de 117 participantes, pois houve perda das respostas de um participante.

No T2, também se verificou que o IA consiste na única escala em que o escore médio padronizado dos participantes está acima de um desvio-padrão, sendo que sua mediana $(60,5)$ indica que metade dos participantes está acima desse valor. Em todas as outras escalas, os escores médios padronizados estão dentro do intervalo de mais ou menos um desvio-padrão. Os mínimos e os máximos nessas escalas indicam, todavia, que há participantes abaixo e acima desta faixa de "normalidade", relativa às pontuações entre 40 e 60, sendo que em alguns casos a pontuação se encontraria a três desvios-padrões acima e dois abaixo da média, indicando a existência de dificuldade em grau significativo nos aspectos representados pelo construto/subescala. 
Tabela 4.11

Escores normatizados nas escalas do IJ-R-Br

\begin{tabular}{|c|c|c|c|c|c|c|c|c|c|c|}
\hline & \multicolumn{5}{|c|}{ Tempo $1(n=117)$} & \multicolumn{5}{|c|}{ Tempo $2(n=78)$} \\
\hline Escala & $\mathbf{M}$ & $\mathbf{D P}$ & Mdn & Mín & Máx & $\mathbf{M}$ & DP & Mdn & Mín & Máx \\
\hline DS & 59,9 & 11,5 & 62 & 34 & 78 & 59,2 & 10,4 & 59 & 39 & 79 \\
\hline $\mathrm{OV}$ & 55,8 & 10,3 & 57 & 30 & 73 & 55,3 & 9,6 & 54 & 28 & 81 \\
\hline IM & 52,8 & 12,9 & 53 & 25 & 75 & 53,1 & 11,9 & 53 & 29 & 76 \\
\hline $\mathrm{AU}$ & 50,7 & 12,9 & 50 & 28 & 80 & 51,9 & 12,6 & 51,5 & 27 & 78 \\
\hline $\mathrm{AL}$ & 58,1 & 12,5 & 60 & 28 & 77 & 56,6 & 10,9 & 57 & 35 & 78 \\
\hline $\mathrm{AM}$ & 54,4 & 12,9 & 58 & 23 & 75 & 53,5 & 10,9 & 52,5 & 30 & 76 \\
\hline RT/DEP & 52,5 & 11,2 & 53 & 30 & 73 & 53,1 & 12,1 & 53 & 31 & 79 \\
\hline $\mathrm{AS}$ & 53,3 & 10 & 53 & 33 & 70 & 53,4 & 9,7 & 55 & 31 & 74 \\
\hline REP & 54,2 & 11 & 53 & 35 & 85 & 55,4 & 12 & 55 & 32 & 80 \\
\hline NEG & 47,7 & 11,4 & 47 & 27 & 73 & 48 & 10,8 & 45,5 & 30 & 73 \\
\hline IA & 61,6 & 9,9 & 64 & 36 & 80 & 61,3 & 10,9 & 60,5 & 34 & 82 \\
\hline TC & 56,1 & 13,7 & 55 & 25 & 85 & 55,4 & 12,8 & 56 & 31 & 82 \\
\hline TOD & 48,9 & 10,6 & 50 & 25 & 70 & 47,9 & 9,9 & 47,5 & 23 & 69 \\
\hline
\end{tabular}

As tabelas 4.12, 4.13 e 4.14 apresentam os resultados das comparações, no T1, entre os grupos Não Violento (GNV) e Violento (GV), considerando que o critério para pertencer ao GV era ter revelado ao menos um delito violento durante os 12 meses que precederam a primeira entrevista. A Tabela 4.12 traz as comparações entre as medidas da conduta delituosa. Nota-se que o GV maior diversidade e frequência de delitos, tanto oficiais quanto autorrevelados. Em relação à idade em que teriam cometido o primeiro delito e a idade em que foram apreendidos pela primeira vez, os grupos não se distinguiram significativamente. Interessante notar que há aproximadamente quatro anos de diferença entre a idade em que revelaram ter cometido o primeiro delito e a idade em que foram apreendidos pela primeira vez. Outro ponto a se observar é que, mesmo não tendo revelado delitos violentos na entrevista, há adolescentes do GNV que, segundo informação oficial, teriam sido apreendidos, antes da entrevista, por infração violenta, motivo pelo qual a média do grupo foi calculada em 0,6 (e não zero) nesse quesito.

A Tabela 4.13 mostra a comparação entre GNV e GV nas escalas do QCJ. Diferenças significativas foram detectadas em pelo menos uma escala de cada domínio do QCJ. Chama a atenção o fato de os adolescentes do GV perceberem-se com melhores resultados acadêmicos que os adolescentes do GNV, embora tenham, em média, a mesma quantidade de anos de 
atraso escolar. No restante das comparações em que foram identificadas diferenças significativas, o GV pontuou mais alto nas escalas de fatores de risco e mais baixo nas escalas de fatores de proteção.

A Tabela 4.14 apresenta a comparação entre os escores normatizados do IJ-R-Br. Os grupos não se diferenciaram na escala de Agressividade Manifesta, Ansiedade Social e Repressão. Na escala Negação, o GNV apresentou média estatisticamente maior. Em todas as outras escalas, a média do GV foi superior. A magnitude das diferenças foi de média a grande em quatro das comparações (DS, OV, Au e ODD > 0,50) e de grande a muito grande na escala de Transtorno de Conduta (>0,70). 
Tabela 4.12

Comparação das médias de idade do primeiro delito, diversidade e frequência anual de delitos entre os grupos GNV e GV (Autorrelato - T1)

\begin{tabular}{|c|c|c|c|c|c|c|c|c|c|c|c|c|}
\hline \multirow[b]{2}{*}{ Delitos } & \multicolumn{5}{|c|}{ GNV $(n=72)$} & \multicolumn{5}{|c|}{ GV $(n=46)$} & \multirow[b]{2}{*}{ d de Cohen } & \multirow[b]{2}{*}{$\mathbf{p}$} \\
\hline & $\mathbf{M}$ & DP & Mdn & Mín & Máx & $\mathbf{M}$ & DP & Mdn & Mín & Máx & & \\
\hline AUTORREVELADOS & & & & & & & & & & & & \\
\hline Idade do primeiro delito & 12,5 & 2,1 & 13 & 8 & 17 & 11,7 & 2,1 & 12 & 7 & 15 & $-0,37$ & 0,06 \\
\hline Diversidade de delitos & 4,3 & 3,2 & 3,5 & $\mathbf{0}$ & 11 & 8,4 & 2,6 & 9 & 3 & 13 & 1,34 & $\mathbf{0 , 0 0}$ \\
\hline Freq. de delitos (último ano) & 21,3 & 39,1 & 2 & $\mathbf{0}$ & 208 & 103,0 & 110,9 & 70 & 1 & 585 & 1,16 & $\mathbf{0 , 0 0}$ \\
\hline Diversidade delitos violentos & 0,8 & 1,1 & $\mathbf{0}$ & $\mathbf{0}$ & 3 & 2,1 & 0,9 & 2 & 1 & 4 & 1,17 & $\mathbf{0 , 0 0}$ \\
\hline Freq. delitos violentos (último ano) & $\mathbf{0 , 0}$ & $\mathbf{0 , 0}$ & $\mathbf{0}$ & $\mathbf{0}$ & $\mathbf{0}$ & 16,9 & 31,7 & 6,5 & 1 & 151 & $\mathbf{0 , 9 5}$ & $\mathbf{0 , 0 0}$ \\
\hline OFICIAIS & & & & & & & & & & & & \\
\hline Idade do primeiro delito & 15,8 & 1,1 & 15,7 & 13,8 & 18,0 & 15,6 & 1,4 & 15,7 & 12,6 & 18,1 & $-0,13$ & 0,49 \\
\hline Freq. de delitos & 2,9 & 1,8 & 3 & 1 & 9 & 3,7 & 2,0 & 3 & 1 & 9 & 0,41 & $\mathbf{0 , 0 3}$ \\
\hline Freq. de delitos Violentos & 0,6 & $\mathbf{0 , 7}$ & $\mathbf{0}$ & $\mathbf{0}$ & 3 & 1,0 & $\mathbf{1 , 0}$ & 1 & $\mathbf{0}$ & 5 & 0,56 & $\mathbf{0 , 0 0}$ \\
\hline
\end{tabular}

Nota: em negrito, as escalas que diferiram significativamente $(\mathrm{p}<0,05)$. 
Tabela 4.13

Comparação das médias das escalas do QCJ entre os grupos GNV e GV (Autorrelato - T1)

\begin{tabular}{|c|c|c|c|c|c|c|c|c|c|c|c|c|}
\hline & \multicolumn{5}{|c|}{ GNV $(n=72)$} & \multicolumn{5}{|c|}{ GV $(n=46)$} & \multirow[b]{2}{*}{ d de cohen } & \multirow[b]{2}{*}{$\mathbf{p}$} \\
\hline & $\mathbf{M}$ & DP & Mdn & Mín & Máx & $\mathbf{M}$ & DP & Mdn & Mín & Máx & & \\
\hline Impulsividade & 1,8 & 1,4 & 2 & 0 & 5 & 2,0 & 1,3 & 2 & 0 & 5 & 0,13 & 0,49 \\
\hline Valores antissociais & 1,1 & 1,8 & $\mathbf{0}$ & $\mathbf{0}$ & 8 & 2,1 & 2,3 & 1 & $\mathbf{0}$ & 8 & $\mathbf{0 , 5 2}$ & $\mathbf{0 , 0 1}$ \\
\hline Atitude Violenta & 1,3 & 1,1 & 1 & $\mathbf{0}$ & 4 & 2,1 & 1,2 & 2 & $\mathbf{0}$ & 4 & $\mathbf{0 , 7 0}$ & $\mathbf{0 , 0 0}$ \\
\hline Oposição a figuras de autoridade & 1,3 & 1,0 & 1 & $\mathbf{0}$ & 3 & 1,8 & 1,0 & 2 & $\mathbf{0}$ & 3 & $\mathbf{0 , 5 1}$ & $\mathbf{0 , 0 1}$ \\
\hline Problemas com a Polícia e a Justiça & 6,0 & 2,0 & 6,5 & 2 & 8 & 6,7 & 1,6 & 8 & 3 & 8 & 0,38 & $\mathbf{0 , 0 3}$ \\
\hline Investimento familiar & 0,4 & 0,6 & 0 & 0 & 2 & 0,3 & 0,6 & 0 & 0 & 2 & $-0,13$ & 0,49 \\
\hline Apego parental & 2,6 & 1,1 & 3 & $\mathbf{0}$ & 4 & 2,1 & 1,2 & 2 & $\mathbf{0}$ & 4 & $-0,47$ & $\mathbf{0 , 0 1}$ \\
\hline Supervisão Parental & 3,4 & 1,0 & 4 & 1 & 5 & 3,0 & 1,1 & 3 & $\mathbf{0}$ & 5 & $-0,43$ & $\mathbf{0 , 0 3}$ \\
\hline Escola desorganizada & 2,1 & 1,5 & 2 & $\mathbf{0}$ & 5 & 2,9 & 1,7 & 3 & $\mathbf{0}$ & 5 & $\mathbf{0 , 5 1}$ & $\mathbf{0 , 0 1}$ \\
\hline Estresse em contexto escolar & 2,1 & 2,1 & 2 & 0 & 7 & 2,5 & 2,1 & 2 & 0 & 8 & 0,17 & 0,37 \\
\hline Vínculo escolar & 1,4 & 0,7 & 2 & 0 & 2 & 1,2 & 0,8 & 1 & 0 & 2 & $-0,26$ & 0,17 \\
\hline Valores positivos frente à escola e aos estudos & 2,4 & 0,8 & 3 & 0 & 3 & 2,5 & 0,7 & 3 & 0 & 3 & 0,08 & 0,66 \\
\hline Bom desempenho acadêmico & 0,2 & $\mathbf{0 , 4}$ & $\mathbf{0}$ & $\mathbf{0}$ & 1 & 0,5 & 0,5 & $\mathbf{0}$ & $\mathbf{0}$ & 1 & 0,56 & 0,01 \\
\hline Problemas de Comportamento em Contexto Escolar & 3,6 & 1,0 & 4 & 1 & 5 & 4,0 & 0,6 & 4 & 2 & 5 & 0,45 & $\mathbf{0 , 0 1}$ \\
\hline Atraso escolar & 2,2 & 1,2 & 2 & 0 & 5 & 2,1 & 1,0 & 2 & 0 & 5 & $-0,14$ & 0,46 \\
\hline Rotina Desestruturada & 2,6 & 1,7 & 2 & $\mathbf{0}$ & 7 & 3,4 & 1,4 & 3 & $\mathbf{0}$ & 6 & $\mathbf{0 , 5 3}$ & $\mathbf{0 , 0 1}$ \\
\hline Atividades Pró-sociais & 1,1 & 0,9 & 1 & 0 & 4 & 0,9 & 0,9 & 1 & 0 & 4 & $-0,24$ & 0,20 \\
\hline Pares infratores & 6,7 & $\mathbf{3 , 7}$ & 7,5 & $\mathbf{0}$ & 12 & 9,3 & 2,6 & 10 & $\mathbf{0}$ & 12 & $\mathbf{0 , 7 8}$ & $\mathbf{0 , 0 0}$ \\
\hline Bairro deteriorado & 1,1 & 1,0 & 1 & 0 & 3 & 1,2 & 1,1 & 1 & 0 & 3 & 0,10 & 0,62 \\
\hline Percepção de violência e criminalidade no bairro & 2,1 & 1,5 & 2 & $\mathbf{0}$ & 5 & 2,6 & 1,2 & 3 & $\mathbf{0}$ & 5 & 0,39 & 0,04 \\
\hline Controle Informal no bairro & 1,6 & 0,7 & 2 & 0 & 2 & 1,4 & 0,7 & 2 & 0 & 2 & $-0,20$ & 0,29 \\
\hline Controle Formal no bairro & 1,3 & 0,9 & 2 & $\mathbf{0}$ & 2 & 0,9 & 0,9 & 1 & $\mathbf{0}$ & 2 & $-0,39$ & 0,04 \\
\hline Apoio Social & 2,0 & 1,1 & 2 & 0 & 3 & 2,2 & 1,0 & 2,5 & 0 & 3 & 0,18 & 0,33 \\
\hline
\end{tabular}

Nota: em negrito, as escalas que diferiram significativamente $(\mathrm{p}<0,05)$. 
Tabela 4.14

Comparação das médias do escore normatizado do IJ-R-Br entre os grupos GNV e GV (Autorrelato - T1)

\begin{tabular}{|c|c|c|c|c|c|c|c|c|c|c|c|c|}
\hline & \multicolumn{5}{|c|}{ GNV $(n=72)$} & \multicolumn{5}{|c|}{ GV $(n=46)$} & \multirow[b]{2}{*}{ d de cohen } & \multirow[b]{2}{*}{ p } \\
\hline & $\mathbf{M}$ & DP & Mdn & Mín & Máx & $\mathbf{M}$ & DP & Mdn & Mín & Máx & & \\
\hline IA & 59,8 & 10,6 & 63 & 36 & 80 & 64,3 & 8,1 & 65 & 45 & 80 & 0,46 & $\mathbf{0 , 0 1}$ \\
\hline DS & 56,9 & 12,0 & 56 & 34 & 72 & 64,5 & 8,9 & 68 & 34 & 78 & 0,69 & $\mathbf{0 , 0 0}$ \\
\hline OV & 53,7 & 10,6 & 56 & 30 & 73 & $\mathbf{5 8 , 9}$ & 9,1 & 62 & 32 & 73 & $\mathbf{0 , 5 1}$ & $\mathbf{0 , 0 1}$ \\
\hline IM & 51,0 & 13,0 & 50 & 25 & 73 & 55,5 & 12,4 & 53 & 25 & 75 & 0,35 & 0,06 \\
\hline $\mathbf{A U}$ & 47,9 & 12,4 & 47 & 28 & 80 & 55,1 & 12,5 & 57,5 & 30 & 73 & 0,58 & $\mathbf{0 , 0 0}$ \\
\hline AL & 56,5 & 13,3 & 58 & 30 & 77 & 60,7 & 10,9 & 61,5 & 28 & 77 & 0,33 & 0,07 \\
\hline $\mathbf{A M}$ & 51,5 & 12,9 & 53 & 28 & 75 & $\mathbf{5 9 , 0}$ & 11,7 & 60 & 23 & 75 & 0,60 & $\mathbf{0 , 0 0}$ \\
\hline RT.DEP & 51,3 & 12,0 & 53 & 30 & 67 & 54,4 & 9,5 & 53 & 30 & 73 & 0,28 & 0,14 \\
\hline AS & 52,0 & 10,5 & 53 & 33 & 70 & 55,4 & 8,8 & 55 & 33 & 70 & 0,34 & 0,07 \\
\hline REP & 55,6 & 11,1 & 53 & 35 & 85 & 52,1 & 10,7 & 50 & 35 & 80 & $-0,32$ & 0,10 \\
\hline NEG & 48,7 & 11,9 & 47 & 30 & 70 & 46,1 & 10,4 & 47 & 27 & 73 & $-0,23$ & 0,21 \\
\hline CD & 52,4 & 12,9 & 50 & 25 & 80 & 61,8 & 13,0 & 65 & 30 & 85 & $\mathbf{0 , 7 3}$ & $\mathbf{0 , 0 0}$ \\
\hline ODD & 46,9 & 10,7 & 45 & 25 & 70 & 52,1 & 9,6 & 53 & 35 & 70 & $\mathbf{0 , 5 0}$ & $\mathbf{0 , 0 1}$ \\
\hline
\end{tabular}

Nota: em negrito, as escalas que diferiram significativamente $(p<0,05)$. 
Similarmente às três tabelas anteriores, as tabelas 4.15, 4.16 e 4.17 apresentam os resultados das comparações, também no T1, entre os GNV e GV, mas desta vez adotando as informações oficiais como critério de classificação dos grupos.

A tabela 4.15 mostra as comparações entre as medidas da conduta delituosa. Destaca-se que, embora os adolescentes no GNV nunca tenham sido apreendidos por delito violento, esses revelaram uma média de 4,8. As diferenças comportamentais identificadas entre os grupos foram em diversidade de delitos cometidos até aquele momento da vida, no tocante aos delitos violentos e aos não violentos.

A Tabela 4.16 apresenta as comparações dos escores médios das escalas avaliadas pelo QCJ, destacando-se o fato de que nenhuma das comparações se mostraram significativas.

Por último, a Tabela 4.17 apresenta a comparação entre os escores normatizados do IJ-R-Br. Assim como nas escalas do QCJ, os grupos não apresentaram diferenças significativas nas escalas do IJ-R-Br. 
Tabela 4.15

Comparação das médias de idade do primeiro delito, diversidade e frequência anual de delitos entre os grupos GNV e GV (Informação Oficial-T1)

\begin{tabular}{lccccccccccccc}
\hline & \multicolumn{1}{c}{ GNV $(\mathbf{n}=\mathbf{7 2})$} & \multicolumn{1}{c}{ GV $(\mathbf{n}=\mathbf{4 6})$} \\
Delitos & $\mathbf{M}$ & $\mathbf{D P}$ & $\mathbf{M d n}$ & Mín & Máx & M & DP & Mdn & Mín & Máx & d de cohen & p \\
\hline AUTORREVELADOS & & & & & & & & & & & & \\
Idade do primeiro delito & 12,3 & 2,1 & 13 & 8 & 16 & 12,1 & 2,1 & 12 & 7 & 17 & $-0,06$ & 0,76 \\
Diversidade de delitos & $\mathbf{4 , 8}$ & $\mathbf{3 , 6}$ & $\mathbf{4}$ & $\mathbf{0}$ & $\mathbf{1 3}$ & $\mathbf{6 , 8}$ & $\mathbf{3 , 3}$ & $\mathbf{7}$ & $\mathbf{0}$ & $\mathbf{1 2}$ & $\mathbf{0 , 5 8}$ & $\mathbf{0 , 0 0}$ \\
Freq. Delitos (Último Ano) & 45,1 & 95,9 & 8,5 & 0 & 585 & 59,5 & 75,8 & 47 & 0 & 356 & 0,16 & 0,36 \\
Diversidade delitos violentos & $\mathbf{0 , 9}$ & $\mathbf{1 , 1}$ & $\mathbf{0}$ & $\mathbf{0}$ & $\mathbf{4}$ & $\mathbf{1 , 7}$ & $\mathbf{1 , 2}$ & $\mathbf{1 , 5}$ & $\mathbf{0}$ & $\mathbf{4}$ & $\mathbf{0 , 7 2}$ & $\mathbf{0 , 0 0}$ \\
Freq. Delitos Violentos (Último ano) & 4,3 & 20,9 & 0 & 0 & 150 & 8,4 & 21,6 & 0,5 & 0 & 151 & 0,20 & 0,30 \\
\hline OFICIAIS & & & & & & & & & & & \\
Idade do primeiro delito & 15,7 & 1,0 & 15,6 & 13,8 & 18,0 & 15,7 & 1,4 & 15,7 & 12,6 & 18,1 & 0,04 & 0,84 \\
Freq. de Delitos & 3,0 & 1,5 & 3 & 1 & 6 & 3,3 & 2,1 & 3 & 1 & 9 & 0,21 & 0,28 \\
Freq. de Delitos Violentos & $\mathbf{0 , 0}$ & $\mathbf{0 , 0}$ & $\mathbf{0}$ & $\mathbf{0}$ & $\mathbf{0}$ & $\mathbf{1 , 4}$ & $\mathbf{0 , 7}$ & $\mathbf{1}$ & $\mathbf{1}$ & $\mathbf{5}$ & $\mathbf{3 , 3 7}$ & $\mathbf{0 , 0 0}$ \\
\hline
\end{tabular}

Nota: em negrito, as escalas que diferiram significativamente $(\mathrm{p}<0,05)$. 
Tabela 4.16

Comparação das médias nos escores das escalas do QCJ entre os grupos NV e V (Informação oficial - T1)

\begin{tabular}{|c|c|c|c|c|c|c|c|c|c|c|c|c|}
\hline & \multicolumn{5}{|c|}{ GNV $(n=72)$} & \multicolumn{5}{|c|}{ GV $(n=46)$} & \multirow[b]{2}{*}{ d de cohen } & \multirow[b]{2}{*}{ p } \\
\hline & $\mathbf{M}$ & DP & Mdn & Mín & Máx & $\mathbf{M}$ & DP & Mdn & Mín & Máx & & \\
\hline Impulsividade & 2,0 & 1,3 & 2 & 0 & 5 & 1,8 & 1,3 & 2 & 0 & 5 & $-0,14$ & 0,45 \\
\hline Valores antissociais & 1,5 & 2,0 & 1 & 0 & 8 & 1,4 & 2,1 & 1 & 0 & 8 & $-0,03$ & 0,85 \\
\hline Atitude violenta & 1,7 & 1,2 & 1,5 & 0 & 4 & 1,6 & 1,2 & 2 & 0 & 4 & $-0,04$ & 0,83 \\
\hline Oposição a figuras de autoridade & 1,5 & 1,0 & 1 & 0 & 3 & 1,5 & 1,0 & 2 & 0 & 3 & 0,01 & 0,97 \\
\hline Prob. com a polícia e a justiça & 6,3 & 2,0 & 7 & 2 & 8 & 6,3 & 1,8 & 7 & 2 & 8 & 0,04 & 0,81 \\
\hline Investimento familiar & 0,4 & 0,6 & 0 & 0 & 2 & 0,4 & 0,6 & 0 & 0 & 2 & $-0,02$ & 0,93 \\
\hline Apego parental & 2,3 & 1,2 & 2 & 0 & 4 & 2,5 & 1,2 & 3 & 0 & 4 & 0,19 & 0,30 \\
\hline Supervisão parental & 3,2 & 1,1 & 3 & 1 & 5 & 3,3 & 1,1 & 3 & 0 & 5 & 0,14 & 0,47 \\
\hline Escola desorganizada & 2,3 & 1,5 & 2,5 & 0 & 5 & 2,5 & 1,6 & 2,5 & 0 & 5 & 0,08 & 0,68 \\
\hline Estresse em contexto escolar & 2,2 & 2,1 & 2 & 0 & 8 & 2,3 & 2,1 & 2 & 0 & 8 & 0,04 & 0,84 \\
\hline Vínculo escolar & 1,3 & 0,8 & 2 & 0 & 2 & 1,4 & 0,7 & 1,5 & 0 & 2 & 0,02 & 0,90 \\
\hline Valores positivos frente à escola e aos estudos & 2,3 & 0,8 & 2,5 & 0 & 3 & 2,5 & 0,7 & 3 & 0 & 3 & 0,22 & 0,22 \\
\hline Bom desempenho acadêmico & 0,2 & 0,4 & 0 & 0 & 1 & 0,4 & 0,5 & 0 & 0 & 1 & 0,30 & 0,12 \\
\hline Prob. de comp. em contexto escolar & 3,7 & 1,1 & 4 & 1 & 5 & 3,8 & 0,8 & 4 & 2 & 5 & 0,07 & 0,68 \\
\hline Atraso escolar & 2,2 & 1,2 & 2 & 0 & 5 & 2,1 & 1,1 & 2 & 0 & 5 & $-0,05$ & 0,79 \\
\hline Rotina desestruturada & 3,0 & 1,8 & 3 & 0 & 7 & 2,8 & 1,5 & 3 & 0 & 6 & $-0,11$ & 0,54 \\
\hline Atividades pró-sociais & 1,0 & 1,0 & 1 & 0 & 4 & 1,0 & 0,8 & 1 & 0 & 3 & 0,04 & 0,83 \\
\hline Pares infratores & 7,0 & 3,7 & 8 & 0 & 12 & 8,2 & 3,4 & 10 & 0 & 12 & 0,35 & 0,06 \\
\hline Bairro deteriorado & 1,3 & 1,0 & 1 & 0 & 3 & 0,9 & 1,0 & 1 & 0 & 3 & $-0,35$ & 0,06 \\
\hline Percepção de violência e criminalidade no bairro & 2,3 & 1,4 & 2 & 0 & 5 & 2,3 & 1,4 & 3 & 0 & 5 & $-0,06$ & 0,73 \\
\hline Controle Informal no bairro & 1,5 & 0,8 & 2 & 0 & 2 & 1,5 & 0,6 & 2 & 0 & 2 & 0,09 & 0,61 \\
\hline Controle Formal no bairro & 1,2 & 0,9 & 1,5 & 0 & 2 & 1,1 & 0,9 & 1 & 0 & 2 & $-0,18$ & 0,35 \\
\hline Apoio Social & 2,0 & 1,2 & 2 & 0 & 3 & 2,2 & 1,0 & 2 & 0 & 3 & 0,19 & 0,29 \\
\hline
\end{tabular}


Tabela 4.17

Comparação das médias nos escores normatizados das escalas do IJ-R-Br entre os grupos NV e V (Informação oficial $-T 1)$

\begin{tabular}{|c|c|c|c|c|c|c|c|c|c|c|c|c|}
\hline & \multicolumn{5}{|c|}{ GNV $(n=72)$} & \multicolumn{5}{|c|}{$G V(n=46)$} & \multirow[b]{2}{*}{ d de cohen } & \multirow[b]{2}{*}{$\mathbf{p}$} \\
\hline & $\mathbf{M}$ & DP & Mdn & Mín & Máx & $\mathbf{M}$ & DP & Mdn & Mín & Máx & & \\
\hline IA & 62,9 & 10,5 & 65 & 36 & 80 & 60,6 & 9,3 & 63 & 40 & 80 & $-0,23$ & 0,203 \\
\hline DS & 61,7 & 10,5 & 65 & 34 & 72 & 58,4 & 12,1 & 60 & 34 & 78 & $-0,30$ & 0,123 \\
\hline OV & 57,6 & 9,5 & 60 & 31 & 73 & 54,3 & 10,7 & 56 & 30 & 73 & $-0,33$ & 0,084 \\
\hline IM & 54,1 & 12,0 & 55 & 30 & 73 & 51,7 & 13,6 & 50 & 25 & 75 & $-0,19$ & 0,320 \\
\hline $\mathrm{AU}$ & 52,2 & 12,5 & 53 & 28 & 80 & 49,6 & 13,1 & 48,5 & 30 & 73 & $-0,21$ & 0,279 \\
\hline $\mathrm{AL}$ & 60,4 & 10,6 & 60 & 33 & 77 & 56,3 & 13,6 & 60 & 28 & 77 & $-0,35$ & 0,069 \\
\hline $\mathrm{AM}$ & 54,1 & 12,2 & 55 & 28 & 75 & 54,7 & 13,6 & 58 & 23 & 75 & 0,05 & 0,815 \\
\hline RT.DEP & 52,5 & 11,3 & 53 & 30 & 67 & 52,4 & 11,2 & 53 & 30 & 73 & $-0,01$ & 0,953 \\
\hline AS & 53,3 & 10,2 & 53 & 33 & 70 & 53,3 & 9,9 & 53 & 33 & 67 & 0,00 & 0,998 \\
\hline REP & 55,4 & 12,1 & 53 & 35 & 85 & 53,3 & 10,1 & 51,5 & 35 & 80 & $-0,19$ & 0,291 \\
\hline NEG & 46,8 & 10,4 & 47 & 30 & 73 & 48,4 & 12,1 & 47 & 27 & 70 & 0,14 & 0,459 \\
\hline $\mathrm{CD}$ & 56,1 & 13,9 & 55 & 25 & 80 & 56,2 & 13,7 & 55 & 30 & 85 & 0,01 & 0,962 \\
\hline ODD & 47,9 & 10,4 & 50 & 25 & 70 & 49,7 & 10,7 & 50 & 30 & 70 & 0,17 & 0,379 \\
\hline
\end{tabular}


Passando para as comparações no T2, a composição dos grupos foi reformulada, de modo que no $\mathrm{GV}$ se incluiu os adolescentes que revelarem, naquele momento, ao menos um delito violento nos últimos 12 meses. Nessa nova formação, os dois grupos tiveram seu tamanho reduzido, devido à perda de participantes de um tempo ao outro. Em relação às diferenças nos padrões de conduta dos grupos, na Tabela 4.18 é possível conferir que o GV possui maior média de diversidade e frequência anual de delitos que o GNV, embora os adolescentes desse grupo não tenham sido apreendidos com maior frequência que os deste. Todavia, apesar da pontuação inferior, verificou-se que os adolescentes em GNV teriam se iniciado em atividades delituosas precocemente $(M=12,5$ anos $)$ e apresentariam elevada diversidade $(M=4,4)$ e frequência $(M=21,0)$ de delitos, padrões característicos de infratores persistentes.

A tabela 4.19 mostra que o número de escalas do QCJ que antes distinguiam os dois grupos diminuiu. Das 13 escalas em que se constatou diferenças significativas no T1, apenas cinco mantiveram-se diferentes no T2: Atitude Violenta, Oposição a Figuras de Autoridade, Escola Desorganizada, Pares Infratores e Percepção de Violência e Criminalidade no Bairro.

E a Tabela 4.20 mostra a comparação dos dois grupos em relação às novas pontuações obtidas nas escalas do IJ-R-Br, no T2. O Índice de Associabilidade passou a não distinguir os grupos. E semelhante ao T1, a escala de Repressão permaneceu sem distinguir os grupos. Todas as demais escalas foram significativamente distintas. As diferenças de maior magnitude se deram nas escalas DS, OV, AM, AS e TC $(d>0,70)$. 
Tabela 4.18

Comparação das médias de idade do primeiro delito, diversidade e frequência anual de delitos entre os grupos GNV e GV (Autorrelato - T2)

\begin{tabular}{|c|c|c|c|c|c|c|c|c|c|c|c|c|}
\hline \multirow[b]{2}{*}{ Delitos } & \multicolumn{5}{|c|}{ GNV $(n=44)$} & \multicolumn{5}{|c|}{ GV $(n=34)$} & \multirow{2}{*}{$\begin{array}{c}\text { d de } \\
\text { cohen }\end{array}$} & \multirow[b]{2}{*}{ p } \\
\hline & $\mathbf{M}$ & DP & Mdn & Mín & Máx & $\mathbf{M}$ & DP & Mdn & Mín & Máx & & \\
\hline \multicolumn{13}{|l|}{ AUTORREVELADOS } \\
\hline Idade do primeiro delito & 12,5 & 3,3 & 13 & 0 & 16 & 11,7 & 2,8 & 12 & 0 & 15 & $-0,23$ & 0,31 \\
\hline Diversidade de delitos & 4,4 & 3,4 & 4 & $\mathbf{0}$ & 11 & 6,8 & 3,6 & 7 & $\mathbf{0}$ & 14 & 0,69 & $\mathbf{0 , 0 0}$ \\
\hline Freq. de delitos (último ano) & 21,0 & 43,7 & 3 & $\mathbf{0}$ & 210 & 67,3 & 87,1 & 59 & $\mathbf{0}$ & 357 & $\mathbf{0 , 7 6}$ & 0,01 \\
\hline Diversidade delitos violentos & 1,2 & 1,2 & 1 & 0 & 4 & 1,7 & 1,3 & 2 & 0 & 4 & 0,45 & 0,06 \\
\hline Freq. de delitos violentos (último ano) & $\mathbf{1 , 3}$ & 2,9 & $\mathbf{1}$ & $\mathbf{0}$ & 19 & 11,3 & 28,2 & $\mathbf{1 , 5}$ & $\mathbf{0}$ & 152 & 0,63 & 0,046 \\
\hline \multicolumn{13}{|l|}{ OFICIAIS } \\
\hline Idade do primeiro delito & 15,8 & 1,1 & 15,7 & 13,8 & 18,0 & 15,6 & 1,4 & 15,7 & 12,6 & 18,1 & $-0,13$ & 0,62 \\
\hline Freq. de delitos & 2,9 & 1,8 & 3 & 1 & 9 & 3,7 & 2,0 & 3 & 1 & 9 & 0,41 & 0,05 \\
\hline Freq. de delitos violentos & $\mathbf{0 , 6}$ & $\mathbf{0 , 7}$ & $\mathbf{0}$ & $\mathbf{0}$ & 3 & $\mathbf{1 , 0}$ & $\mathbf{1 , 0}$ & 1 & $\mathbf{0}$ & 5 & $\mathbf{0 , 5 6}$ & $\mathbf{0 , 0 0}$ \\
\hline
\end{tabular}

Nota: em negrito, as escalas que diferiram significativamente $(\mathrm{p}<0,05)$. 
Tabela 4.19

Comparação das médias nas escalas do QCJ entre os grupos GNV e GV (Autorrelato - T2)

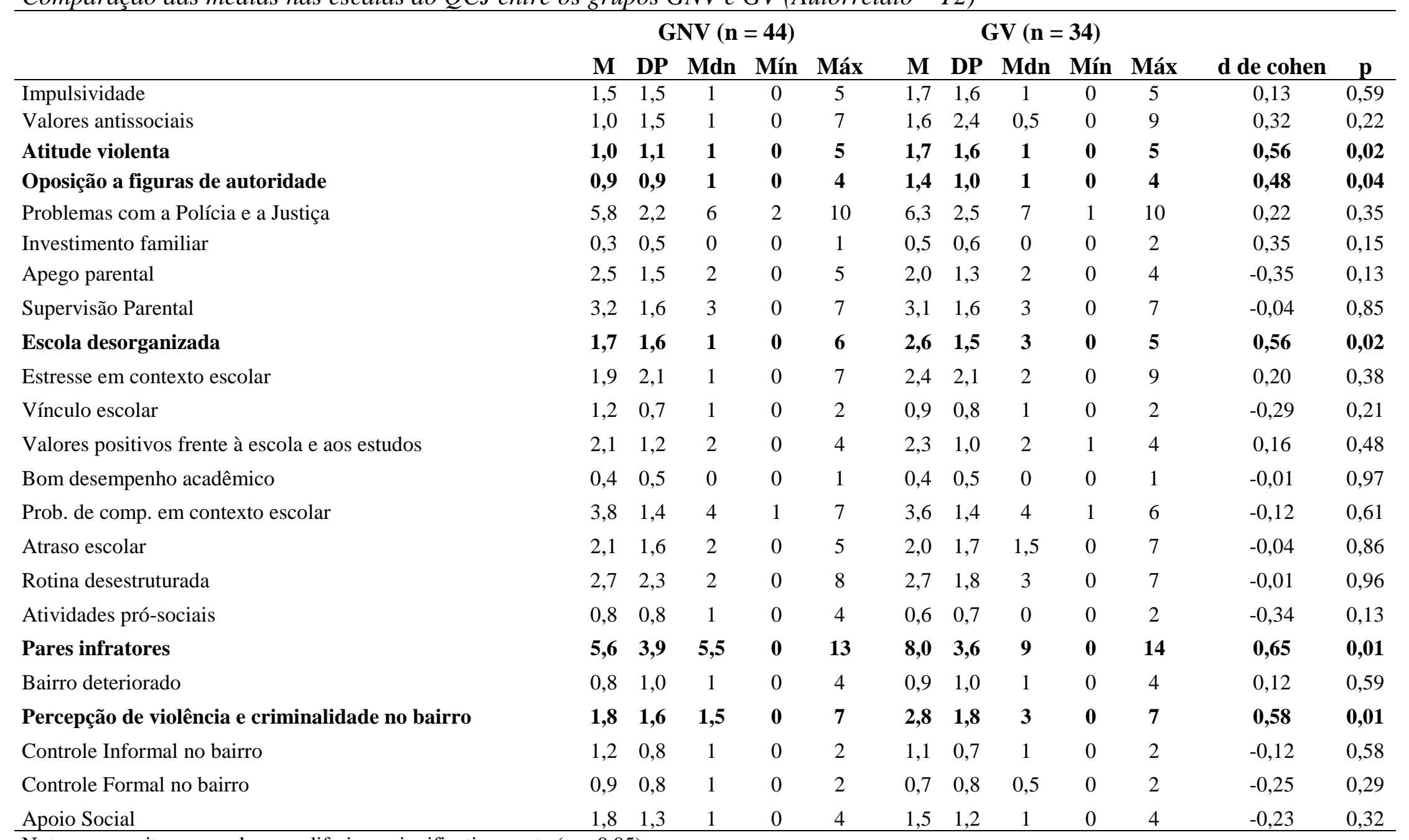

Nota: em negrito, as escalas que diferiram significativamente $(\mathrm{p}<0,05)$. 
Tabela 4.20

Comparação das médias nas escalas do IJ-R-Br entre os grupos GNV e GV (Autorrelato-T2)

\begin{tabular}{|c|c|c|c|c|c|c|c|c|c|c|c|c|}
\hline & \multicolumn{5}{|c|}{ GNV $(n=44)$} & \multicolumn{5}{|c|}{ GV $(n=34)$} & \multirow[b]{2}{*}{ d de cohen } & \multirow[b]{2}{*}{$\mathbf{p}$} \\
\hline & M & DP & Mdn & Mín & Máx & $\mathbf{M}$ & DP & Mdn & Mín & Máx & & \\
\hline IA & 60,2 & 11,1 & 61 & 34 & 82 & 62,1 & 10,3 & 59,5 & 44 & 82 & 0,17 & 0,46 \\
\hline DS & 54,9 & 10,0 & 53 & 39 & 79 & 64,8 & 8,2 & 66 & 40 & 76 & 1,05 & $\mathbf{0 , 0 0}$ \\
\hline OV & 52,5 & 8,6 & 52,5 & 28 & 70 & $\mathbf{5 8 , 9}$ & 9,8 & 57,5 & 43 & 81 & 0,71 & $\mathbf{0 , 0 0}$ \\
\hline IM & $\mathbf{5 0 , 9}$ & 10,6 & $\mathbf{5 0 , 5}$ & 29 & 76 & 56,3 & 11,3 & 59,5 & 34 & 73 & $\mathbf{0 , 5 0}$ & $\mathbf{0 , 0 3}$ \\
\hline $\mathbf{A U}$ & 49,2 & 12,0 & 47 & 27 & 74 & 55,1 & 12,3 & 56,5 & 32 & 78 & 0,49 & 0,04 \\
\hline $\mathbf{A L}$ & 54,1 & 9,6 & 52,5 & 35 & 78 & 59,7 & 11,7 & 62 & 38 & 78 & 0,55 & $\mathbf{0 , 0 2}$ \\
\hline $\mathbf{A M}$ & 48,8 & 9,2 & 48 & 30 & 69 & 59,5 & 10,1 & 60,5 & 39 & 76 & 1,13 & $\mathbf{0 , 0 0}$ \\
\hline RT.DEP & 50,7 & 11,6 & $\mathbf{5 0 , 5}$ & 31 & 72 & 55,9 & 11,2 & 57 & 32 & 79 & 0,46 & 0,05 \\
\hline $\mathbf{A S}$ & $\mathbf{5 0 , 3}$ & 9,4 & $\mathbf{5 0 , 5}$ & 30 & 70 & 56,8 & 9,1 & 57 & 38 & 74 & $\mathbf{0 , 7 0}$ & $\mathbf{0 , 0 0}$ \\
\hline REP & 57,0 & 12,7 & 56 & 35 & 80 & 53,4 & 10,7 & 51 & 32 & 78 & $-0,30$ & 0,19 \\
\hline NEG & $\mathbf{5 0 , 7}$ & 11,4 & 51 & 30 & 74 & 46,0 & 9,6 & 44,5 & 31 & 67 & $-0,44$ & $\mathbf{0 , 0 5}$ \\
\hline CD & 51,0 & 12,0 & 48,5 & 31 & 78 & 60,7 & 11,9 & 60 & 31 & 82 & $\mathbf{0 , 8 1}$ & $\mathbf{0 , 0 0}$ \\
\hline ODD & 45,4 & $\mathbf{9 , 1}$ & 45 & 23 & 64 & 51,3 & 10,1 & 51,5 & 27 & 69 & $\mathbf{0 , 6 3}$ & $\mathbf{0 , 0 1}$ \\
\hline
\end{tabular}

Nota: em negrito, as escalas que diferiram significativamente $(\mathrm{p}<0,05)$. 
Ademais, destaca-se uma comparação entre GNV e GV, no T2, que não foi feita no T1. A Tabela 4.19 mostra os escores médios obtidos nas tarefas do Teste de Stroop - Victoria (TS-V) e do Teste das Torres de Londres (TOL). O GV (M = 2,4) obteve mais erros no cartão 3 do Teste de Stroop que o GNV $(M=1,6)$. Em relação aos tempos para completar as tarefas deste teste, os grupos não se diferenciaram estatisticamente. O tempo para iniciar o TOL e o tempo para finalizar a tarefa também não diferenciou os grupos estatisticamente, mas o $\mathrm{GV}(\mathrm{M}=5,3)$ precisou de mais movimentos para completar a tarefa comparado ao GNV $(\mathrm{M}=4,2)$. 
Tabela 4.21

Comparação das médias nos escores dos testes Stroop e TOL entre os grupos NV e V (Autorrelato - T2)

\begin{tabular}{|c|c|c|c|c|c|c|c|c|c|c|c|c|}
\hline & \multicolumn{5}{|c|}{ GNV $(n=44)$} & \multicolumn{5}{|c|}{$\mathrm{GV}(\mathrm{n}=34)$} & \multirow{2}{*}{$d$ Cohen } & \multirow{2}{*}{$\mathrm{p}$} \\
\hline & $\mathrm{M}$ & $\mathrm{DP}$ & Mdn & Mín & Máx & $M$ & $\mathrm{DP}$ & Mdn & Mín & Máx & & \\
\hline Stroop - Tempo 1 & 13 & 2,6 & 13 & 9 & 17 & 13,6 & 2,7 & 14 & 9 & 18 & $-0,2$ & 0,354 \\
\hline Stroop - Tempo 2 & 14,1 & 3,5 & 14 & 9 & 20 & 14,6 & 3,1 & 14 & 10 & 20 & $-0,2$ & 0,503 \\
\hline Stroop - Tempo 3 & 22,1 & 6,8 & 23 & 11 & 34 & 20,7 & 7,5 & 20,5 & 11 & 37 & 0,2 & 0,395 \\
\hline Stroop erro - cartão 3 & 1,6 & 1,4 & 2 & $\mathbf{0}$ & 4 & 2,4 & 1,7 & 3 & $\mathbf{0}$ & 5 & $-0,5$ & $\mathbf{0 , 0 3 8}$ \\
\hline TOL - tempo para iniciar & 13,8 & 4,5 & 13 & 5 & 22 & 14 & 5,2 & 14,5 & 5 & 21 & 0 & 0,858 \\
\hline TOL - tempo para finalizar & 39,9 & 11,5 & 38 & 21 & 60 & 37,1 & 11,8 & 34 & 17 & 58 & 0,2 & 0,295 \\
\hline TOL - movimentos extras & 4,2 & 1,7 & 4 & $\mathbf{0}$ & 9 & 5,3 & 2,5 & 5 & 1 & 15 & $-0,5$ & $\mathbf{0 , 0 2 5}$ \\
\hline
\end{tabular}

Nota: em negrito, as escalas que diferiram significativamente $(p<0,05)$. 
As tabelas 4.22, 4.23, 4.24 e 4.25 apresentam as mesmas comparações entre GNV e GV no QCJ, no IJ-R-Br e nos testes TS-V e TOL, com a diferença de que os grupos foram definidos a partir de informações do histórico oficial de delitos. Na Tabela 4.20 observa-se que, além das diferenças em diversidade de delitos autorrevelados, identificadas no T1, a frequência de delitos autorrevelados no decorrer do último ano também indicou diferenças significativas entre os grupos. Embora as frequências tenham, em média, diminuído de um tempo a outro (em GNV esta teria reduzido de 45,5 para 14,7; em GV, de 59,6 para 58,6), os valores continuaram altos.

Em relação às escalas do $\mathrm{QCJ}$, os grupos, que no $\mathrm{T} 1$ não diferiram significativamente em nenhuma, passaram a apresentar médias estatisticamente distintas na escala de Pares Infratores, conforme mostra a Tabela 4.23. O GV (M = 7,5; DP = $3,7)$ apresentou maior pontuação que o $\operatorname{GNV}(\mathrm{M}=5,4$; $\mathrm{DP}=4,0)$, sendo que essa diferença pode ser considerada de magnitude moderada $(d=0,55)$.

E a Tabela 4.24 mostra que, assim como no T1, os grupos não se diferenciaram em nenhuma das escalas do IJ-R-Br. Nota-se, contudo, que ambos os grupos estão com a média no Índice de Associabilidade acima da faixa de normalidade prevista pelo instrumento.

Por último, nas comparações entre as medidas avaliadas pelo Teste de Stroop e TOL, os grupos não apresentaram nenhuma diferença significativa (Tabela 4.25). Em resumo, observa-se que em todas as comparações entre GNV e GV, quando estes são formados tendo como critério as informações oficiais, encontram-se menos diferenças significativas e menor magnitude entre as diferenças quando comparados aos GNV e GV formados tendo como critério as informações autorreveladas. 
Tabela 4.22

Comparação das médias de idade do primeiro delito, diversidade e frequência anual de delitos entre os grupos GNV e GV (Informação oficial-T2)

\begin{tabular}{lccccccccccccc}
\hline & \multicolumn{1}{c}{ GNV $(\mathbf{n}=\mathbf{3 1})$} & \multicolumn{1}{c}{ GV $(\mathbf{n}=\mathbf{4 7})$} \\
Delitos & $\mathbf{M}$ & $\mathbf{D P}$ & Mdn & Mín & Máx & M & DP & Mdn & Mín & Máx & d de cohen & p \\
\hline AUTORREVELADOS & & & & & & & & & & & & \\
Idade do primeiro delito & 12,1 & 3,7 & 13 & 0 & 16 & 12,1 & 2,7 & 12 & 0 & 16 & 0,01 & 0,98 \\
Diversidade de delitos & $\mathbf{3 , 4}$ & $\mathbf{3 , 0}$ & $\mathbf{3}$ & $\mathbf{0}$ & $\mathbf{1 1}$ & $\mathbf{6 , 8}$ & $\mathbf{3 , 4}$ & $\mathbf{7}$ & $\mathbf{0}$ & $\mathbf{1 4}$ & $\mathbf{1 , 0 8}$ & $\mathbf{0 , 0 0}$ \\
Freq. de delitos (último ano) & $\mathbf{1 4 , 7}$ & $\mathbf{2 4 , 6}$ & $\mathbf{3}$ & $\mathbf{0}$ & $\mathbf{9 1}$ & $\mathbf{5 8 , 6}$ & $\mathbf{8 3 , 3}$ & $\mathbf{4 4}$ & $\mathbf{0}$ & $\mathbf{3 5 7}$ & $\mathbf{0 , 8 6}$ & $\mathbf{0 , 0 0}$ \\
Diversidade delitos violentos & $\mathbf{1 , 0}$ & $\mathbf{1 , 0}$ & $\mathbf{1}$ & $\mathbf{0}$ & $\mathbf{3}$ & $\mathbf{1 , 7}$ & $\mathbf{1 , 3}$ & $\mathbf{2}$ & $\mathbf{0}$ & $\mathbf{4}$ & $\mathbf{0 , 6 3}$ & $\mathbf{0 , 0 1}$ \\
Freq. de delitos violentos (último ano) & 1,0 & 2,0 & 1 & 0 & 11 & 8,7 & 24,3 & 1 & 0 & 152 & 0,55 & 0,04 \\
\hline OFICIAIS & & & & & & & & & & & \\
Idade do primeiro delito & 15,6 & 1,0 & 15,5 & 13,8 & 18 & 15,8 & 1,4 & 15,8 & 12,6 & 18,1 & 0,21 & 0,40 \\
Freq. de delitos & 3,1 & 1,8 & 3,0 & 1,0 & 6,0 & 3,4 & 2,1 & 3,0 & 1,0 & 9,0 & 0,17 & 0,48 \\
Freq. de delitos violentos & $\mathbf{0 , 0}$ & $\mathbf{0 , 0}$ & $\mathbf{0}$ & $\mathbf{0}$ & $\mathbf{0}$ & $\mathbf{1 , 4}$ & $\mathbf{0 , 8}$ & $\mathbf{1}$ & $\mathbf{1}$ & $\mathbf{5}$ & $\mathbf{3 , 2 3}$ & $\mathbf{0 , 0 0}$ \\
\hline
\end{tabular}

Nota: em negrito, as escalas que diferiram significativamente $(\mathrm{p}<0,05)$. 
Tabela 4.23

Comparação das médias nos escores das escalas do QCJ entre os grupos NV e V (Informação oficial - T2)

\begin{tabular}{|c|c|c|c|c|c|c|c|c|c|c|c|c|}
\hline & \multicolumn{5}{|c|}{ GNV $(\mathbf{n}=31)$} & \multicolumn{5}{|c|}{ GV $(n=47)$} & \multirow[b]{2}{*}{ d de cohen } & \multirow[b]{2}{*}{ p } \\
\hline & $\mathbf{M}$ & DP & Mdn & Mín & Máx & $\mathbf{M}$ & DP & Mdn & Mín & Máx & & \\
\hline Impulsividade & 1,7 & 1,5 & 1 & 0 & 5 & 1,6 & 1,5 & 1 & 0 & 5 & $-0,12$ & 0,60 \\
\hline Valores antissociais & 1,2 & 1,5 & 1 & 0 & 7 & 1,3 & 2,2 & 0 & 0 & 9 & 0,03 & 0,89 \\
\hline Atitude violenta & 1,2 & 1,4 & 1 & 0 & 5 & 1,3 & 1,4 & 1 & 0 & 5 & 0,08 & 0,73 \\
\hline Oposição a figuras de autoridade & 1,0 & 0,9 & 1 & 0 & 4 & 1,2 & 1,0 & 1 & 0 & 4 & 0,21 & 0,38 \\
\hline Problemas com a polícia e a justiça & 5,8 & 2,3 & 6 & 1 & 10 & 6,2 & 2,4 & 7 & 1 & 10 & 0,17 & 0,48 \\
\hline Investimento familiar & 0,3 & 0,5 & 0 & 0 & 1 & 0,4 & 0,5 & 0 & 0 & 2 & 0,16 & 0,49 \\
\hline Apego parental & 2,5 & 1,7 & 3 & 0 & 5 & 2,2 & 1,3 & 2 & 0 & 5 & $-0,20$ & 0,34 \\
\hline Supervisão Parental & 3,2 & 1,7 & 3 & 1 & 7 & 3,1 & 1,5 & 3 & 0 & 7 & $-0,07$ & 0,77 \\
\hline Escola desorganizada & 2,0 & 1,6 & 2 & 0 & 5 & 2,2 & 1,7 & 2 & 0 & 6 & 0,12 & 0,62 \\
\hline Estresse em contexto escolar & 2,1 & 1,8 & 1 & 0 & 7 & 2,1 & 2,3 & 1 & 0 & 9 & 0,02 & 0,95 \\
\hline Vínculo escolar & 1,2 & 0,8 & 1 & 0 & 2 & 1,0 & 0,8 & 1 & 0 & 2 & $-0,21$ & 0,36 \\
\hline Valores positivos frente à escola e aos estudos & 2,2 & 1,0 & 2 & 1 & 4 & 2,2 & 1,2 & 2 & 0 & 4 & 0,05 & 0,84 \\
\hline Bom desempenho acadêmico & 0,3 & 0,5 & 0 & 0 & 1 & 0,4 & 0,5 & 0 & 0 & 1 & 0,21 & 0,37 \\
\hline $\begin{array}{l}\text { Prob. de comp. em contexto escolar } \\
\text { Atraso escolar }\end{array}$ & $\begin{array}{l}3,8 \\
2,3\end{array}$ & $\begin{array}{l}1,7 \\
1,9\end{array}$ & $\begin{array}{l}4 \\
2\end{array}$ & $\begin{array}{l}1 \\
0\end{array}$ & $\begin{array}{l}7 \\
7\end{array}$ & $\begin{array}{l}3,6 \\
1,9\end{array}$ & $\begin{array}{l}1,1 \\
1,5\end{array}$ & $\begin{array}{l}4 \\
2\end{array}$ & $\begin{array}{l}1 \\
0\end{array}$ & $\begin{array}{l}6 \\
5\end{array}$ & $\begin{array}{l}-0,14 \\
-0,21\end{array}$ & $\begin{array}{l}0,51 \\
0,34\end{array}$ \\
\hline $\begin{array}{l}\text { Rotina desestruturada } \\
\text { Atividades pró-sociais }\end{array}$ & $\begin{array}{l}2,7 \\
0,9\end{array}$ & $\begin{array}{l}2,4 \\
0,9\end{array}$ & $\begin{array}{l}2 \\
1\end{array}$ & $\begin{array}{l}0 \\
0\end{array}$ & $\begin{array}{l}8 \\
4\end{array}$ & $\begin{array}{l}2,7 \\
0,6\end{array}$ & $\begin{array}{l}1,8 \\
0,6\end{array}$ & $\begin{array}{l}2 \\
1\end{array}$ & $\begin{array}{l}0 \\
0\end{array}$ & $\begin{array}{l}7 \\
2\end{array}$ & $\begin{array}{c}0,03 \\
-0,40\end{array}$ & $\begin{array}{l}0,89 \\
0,06\end{array}$ \\
\hline Pares infratores & 5,4 & 4,0 & 5 & $\mathbf{0}$ & 13 & 7,5 & 3,7 & 8 & $\mathbf{0}$ & 14 & $\mathbf{0 , 5 5}$ & $\mathbf{0 , 0 2}$ \\
\hline Bairro deteriorado & 1,0 & 0,9 & 1 & 0 & 3 & 0,8 & 1,0 & 1 & 0 & 4 & $-0,16$ & 0,49 \\
\hline Percepção de violência e criminalidade no bairro & 2,2 & 1,7 & 2 & 0 & 7 & 2,3 & 1,8 & 2 & 0 & 7 & 0,04 & 0,88 \\
\hline Controle Informal no bairro & 1,1 & 0,8 & 1 & 0 & 2 & 1,1 & 0,7 & 1 & 0 & 2 & 0,03 & 0,91 \\
\hline Controle Formal no bairro & 0,9 & 0,8 & 1 & 0 & 2 & 0,8 & 0,8 & 1 & 0 & 2 & $-0,12$ & 0,62 \\
\hline Apoio Social & 1,6 & 1,2 & 1 & 0 & 4 & 1,7 & 1,3 & 1 & 0 & 4 & 0,11 & 0,63 \\
\hline
\end{tabular}

Nota: em negrito, as escalas que diferiram significativamente $(\mathrm{p}<0,05)$. 
Tabela 4.24

Comparação das médias nos escores normatizados das escalas do IJ-R-Br entre os grupos NV e V (Informação oficial $-T 2)$

\begin{tabular}{|c|c|c|c|c|c|c|c|c|c|c|c|c|}
\hline & \multicolumn{5}{|c|}{ GNV $(n=31)$} & \multicolumn{5}{|c|}{$\mathrm{GV}(\mathrm{n}=47)$} & \multirow[b]{2}{*}{ d de cohen } & \multirow[b]{2}{*}{$\mathrm{p}$} \\
\hline & $M$ & DP & Mdn & Mín & Máx & $\mathrm{M}$ & $\mathrm{DP}$ & Mdn & Mín & Máx & & \\
\hline IA & 61,0 & 11,7 & 61 & 34 & 82 & 61,0 & 10,2 & 60 & 43 & 82 & 0,00 & 0,997 \\
\hline DS & 59,2 & 10,7 & 58 & 41 & 79 & 59,3 & 10,3 & 61 & 39 & 76 & 0,01 & 0,962 \\
\hline OV & 57,0 & 9,9 & 58 & 33 & 81 & 54,2 & 9,3 & 53 & 28 & 72 & $-0,29$ & 0,205 \\
\hline IM & 53,2 & 10,7 & 53 & 30 & 76 & 53,3 & 11,6 & 53 & 29 & 73 & 0,01 & 0,978 \\
\hline $\mathrm{AU}$ & 52,4 & 12,4 & 51 & 30 & 74 & 51,4 & 12,5 & 52 & 27 & 78 & $-0,08$ & 0,737 \\
\hline $\mathrm{AL}$ & 57,8 & 10,7 & 58 & 38 & 78 & 55,7 & 11,0 & 56 & 35 & 78 & $-0,19$ & 0,415 \\
\hline $\mathrm{AM}$ & 51,6 & 10,7 & 52 & 30 & 74 & 54,7 & 11,1 & 53 & 34 & 76 & 0,28 & 0,236 \\
\hline RT.DEP & 52,4 & 10,6 & 53 & 32 & 70 & 53,4 & 12,4 & 52 & 31 & 79 & 0,09 & 0,705 \\
\hline AS & 50,6 & 9,6 & 52 & 30 & 74 & 54,8 & 9,6 & 56 & 36 & 70 & 0,44 & 0,063 \\
\hline REP & 58,1 & 13,1 & 57 & 36 & 80 & 53,6 & 10,8 & 54 & 32 & 78 & $-0,36$ & 0,101 \\
\hline NEG & 47,6 & 10,9 & 45 & 30 & 74 & 49,4 & 10,9 & 48 & 31 & 69 & 0,16 & 0,482 \\
\hline $\mathrm{CD}$ & 52,8 & 13,0 & 52 & 31 & 78 & 56,8 & 12,7 & 57 & 36 & 82 & 0,31 & 0,178 \\
\hline ODD & 45,7 & 10,0 & 45 & 23 & 64 & 49,4 & 9,7 & 50 & 32 & 69 & 0,38 & 0,106 \\
\hline
\end{tabular}


Tabela 4.25

Comparação das médias nos escores dos testes Stroop e TOL entre os grupos NV e V (Informação oficial - T2)

\begin{tabular}{|c|c|c|c|c|c|c|c|c|c|c|c|c|}
\hline & \multicolumn{5}{|c|}{ Não Violento $(n=31)$} & \multicolumn{5}{|c|}{ Violento $(n=47)$} & \multirow{2}{*}{$\begin{array}{c}\text { d de } \\
\text { Cohen }\end{array}$} & \multirow{2}{*}{$\mathbf{p}$} \\
\hline & $\mathbf{M}$ & DP & Mdn & Mín & Máx & $\mathbf{M}$ & DP & Mdn & Mín & Máx & & \\
\hline Stroop $-\mathrm{T} 1$ & 13,6 & 2,4 & 14 & 9 & 17 & 13 & 2,8 & 13 & 9 & 18 & 0,3 & 0,274 \\
\hline Stroop - T2 & 14,3 & 3,3 & 13 & 9 & 20 & 14,4 & 3,3 & 15 & 9 & 20 & $-0,1$ & 0,829 \\
\hline Stroop - tempo 3 & 22,7 & 7,8 & 24 & 11 & 34 & 20,7 & 6,6 & 21 & 11 & 37 & 0,3 & 0,222 \\
\hline Stroop erro - cartão 3 & 1,9 & 1,6 & 2 & 0 & 4 & 2 & 1,6 & 2 & 0 & 5 & $-0,1$ & 0,7 \\
\hline TOL - T1nicio & 13,1 & 5 & 13 & 5 & 21 & 14,4 & 4,6 & 14 & 5 & 22 & $-0,3$ & 0,236 \\
\hline TOL - tempo finalizar & 39,7 & 12,5 & 38 & 17 & 60 & 37,9 & 11,2 & 37 & 19 & 59 & 0,1 & 0,514 \\
\hline TOL - mov. extras & 4,6 & 1,3 & 5 & 3 & 9 & 4,7 & 2,6 & 4 & 0 & 15 & 0 & 0,917 \\
\hline
\end{tabular}


Sintetizando as informações dos grupos, segundo critério de divisão a partir da delinquência autorrevelada, os adolescentes tiveram suas pontuações normatizadas segundo o escore-z com base nos parâmetros da população normativa de adolescentes de escolas públicas e privadas com mais de 17 anos $(\mathrm{n}=195)$ obtidos por Komatsu, Costa, Salgado e Bazon (2019) e comparadas com a pontuação que a amostra, como um todo, obteve no T1 (Figura 4.4). Foram destacadas com um asterisco as diferenças de meio desvio-padrão em relação à população normativa, e com dois asteriscos as diferenças acima de um desviopadrão em relação à população normativa.

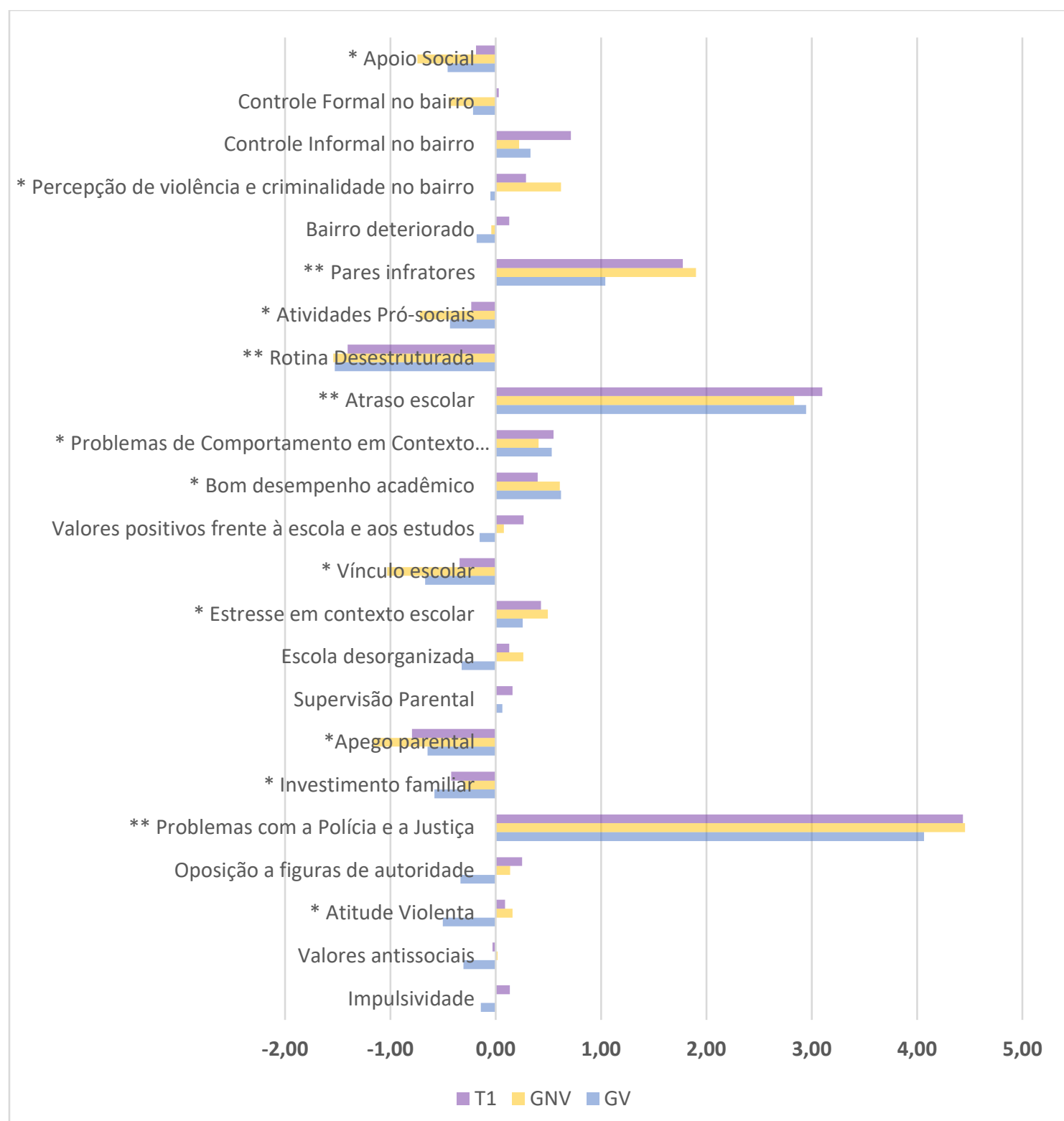

Figura 4.4. Escores normatizados dos adolescentes no T1, do GNV no T2 e do GV no T2 em relação às escalas do QCJ (Fonte: autor) 
Passando para o objetivo de identificar mudanças no plano das condutas delitivas, em especial à violência, atreladas a alterações nos fatores investigados em nível pessoal e social, ressalta-se incialmente que dos adolescentes remanescentes, ou seja, em meio ao total de adolescentes reencontrado no T2, 27 persistiram em condutas violentas (V-V), sete não haviam manifesto condutas violentas e passaram a manifestar (NV-V), 15 haviam manifesto condutas violentas e deixaram de fazê-lo (V-NV), e 29 continuaram sem manifestar condutas violentas (NV-NV). Focalizando os adolescentes em relação aos quais se denotou descontinuidade na trajetória da conduta, V-NV $(n=15)$ e NV-V $(n=7)$, implementou-se o teste não paramétrico de Wilcoxon para amostras pareadas visando comparar o desempenho dos participantes com eles próprios em todas as escalas do QCJ e do IJ-R-Br. Os resultados dessas comparações são mostrados nas tabelas 4.26, 4.27, 4.28, 4.29, 4.30 e 4.31.

Em termos condutuais, os adolescentes reunidos em V-NV, embora não tenham cometido mais nenhum delito violento, revelaram uma diversidade maior de delitos no T2 (M $=8,1 ; \mathrm{Mdn}=8,0)$, comparando ao que haviam revelado no $\mathrm{T} 1(\mathrm{M}=7,3 ; \mathrm{Mdn}=7)$, como mostra a tabela 4.26. Em relação à frequência de delitos, apesar de haver, em média, uma redução numericamente grande do $\mathrm{T} 1(\mathrm{M}=36,3 ; \mathrm{Mdn}=12)$ para o $\mathrm{T} 2(\mathrm{M}=15,9 ; \mathrm{Mdn}=6)$, as evidências não foram suficientes para afirmar que essas diferenças foram significativas ( $p$ $=0,36)$.

\section{Tabela 4.26}

Comparação dos escores do grupo $V-N V(n=15)$ com ele mesmo em relação à diversidade de atos divergentes e diversidade e frequência anual de delitos - teste de Wilcoxon

\begin{tabular}{|c|c|c|c|c|c|c|c|c|c|c|c|c|}
\hline \multirow[b]{2}{*}{ DELITOS } & \multicolumn{5}{|c|}{ T1 } & \multicolumn{7}{|c|}{$\mathbf{T 2}$} \\
\hline & $\mathbf{M}$ & DP & Mdn & Mín & Máx & $\mathbf{M}$ & DP & Mdn & Mín & Máx & $\mathbf{Z}$ & $\mathbf{P}$ \\
\hline Diversida-de & 7,3 & 3,2 & 7 & 2 & 12 & 8,1 & 2,5 & 8,0 & 4 & 12 & $-2,7$ & $\mathbf{0 , 0 1}$ \\
\hline Frequência & 36,3 & 56,5 & 12 & 0 & 212 & 15,9 & 29,3 & 6,0 & 0 & 117 & $-0,9$ & 0,36 \\
\hline
\end{tabular}

Nas escalas do QCJ, notou-se que o grupo V-NV diminuiu na pontuação de número de Pares Infratores e de Problemas com a Polícia e a Justiça. Como mostra a tabela 4.27, as medianas dessas duas escalas caíram dois pontos do T1 para o T2. 
Tabela 4.27

Comparação dos escores do grupo V-NV $(n=15)$ com ele mesmo nas escalas do QCJ - teste de Wilcoxon

\begin{tabular}{|c|c|c|c|c|c|c|c|c|c|c|c|c|}
\hline & \multicolumn{5}{|c|}{ T1 } & \multicolumn{7}{|c|}{ T2 } \\
\hline & M & DP & Mdn & Mín & Máx & M & DP & Mdn & $\begin{array}{c}\text { Mí } \\
\text { n }\end{array}$ & $\begin{array}{c}\text { Má } \\
\text { x }\end{array}$ & $\mathbf{Z}$ & p \\
\hline $\begin{array}{l}\text { Valores } \\
\text { antissociais } \\
\text { Atitude }\end{array}$ & 0,9 & 1,2 & 0,0 & 0,0 & 4,0 & 1,2 & 0,8 & 1,0 & 0,0 & 2,0 & $-1,0$ & 0,34 \\
\hline Violenta & 1,3 & 1,1 & 1,0 & 0,0 & 4,0 & 1,3 & 0,8 & 1,0 & 0,0 & 3,0 & $-0,2$ & 0,87 \\
\hline $\begin{array}{l}\text { Impulsividade } \\
\text { Valores }\end{array}$ & 1,7 & 1,4 & 1,0 & 0,0 & 5,0 & 2,1 & 1,4 & 2,0 & 0,0 & 5,0 & $-1,7$ & 0,09 \\
\hline $\begin{array}{l}\text { escolares } \\
\text { Repetições na }\end{array}$ & 1,8 & 0,6 & 2,0 & 0,0 & 2,0 & 1,7 & 0,6 & 2,0 & 0,0 & 2,0 & $-0,7$ & 0,48 \\
\hline $\begin{array}{l}\text { escola } \\
\text { Suspensão da }\end{array}$ & 2,1 & 1,2 & 2,0 & 0,0 & 4,0 & 1,2 & 1,1 & 1,0 & 0,0 & $\begin{array}{l}3,0 \\
20\end{array}$ & $-1,8$ & 0,07 \\
\hline Escola & 5,4 & 6,2 & 4,0 & 0,0 & 20,0 & 5,0 & 6,4 & 2,0 & 0,0 & 0 & $-1,0$ & 0,32 \\
\hline $\begin{array}{l}\text { Pares } \\
\text { infratores } \\
\text { Violência no }\end{array}$ & 8,4 & 3,2 & 10,0 & 1,0 & 11,0 & 7,4 & 3,5 & 8,0 & $\mathbf{0 , 0}$ & $\begin{array}{c}12 \\
0\end{array}$ & $-2,5$ & 0,01 \\
\hline $\begin{array}{l}\text { bairro } \\
\text { Problemas } \\
\text { com a Polícia e } \\
\text { a Justiça }\end{array}$ & 2,5 & 1,5 & 3,0 & 0,0 & 4,0 & 2,5 & 0,9 & 2,0 & 1,0 & 4,0 & $-0,3$ & 0,75 \\
\hline
\end{tabular}

Nota: em negrito, as escalas que diferiram significativamente $(\mathrm{p}<0,05)$.

Em relação à pontuação no IJ-R-Br, observou-se redução nas escalas DS, OV, AL e AM (Tabela 4.28). No T1, pelo menos metade dos adolescentes havia pontuado acima de um desvio-padrão em duas dessas escalas (DS, Mdn = 64; AL, Mdn =60), e próximo do limiar de um desvio em outras duas ( $\mathrm{OV}, \mathrm{Mdn}=57$; AM, Mdn = 58). Já no T2, a mediana para essas escalas esteve muito próxima de um desvio-padrão em relação à população normativa (DS = 54; $\mathrm{OV}, \mathrm{AL}$ e $\mathrm{AM}=52$ ). 
Tabela 4.28

Comparação dos escores do grupo $V-N V(n=15)$ com ele mesmo nas escalas do $I J-R-B r-$ teste de Wilcoxon

\begin{tabular}{|c|c|c|c|c|c|c|c|c|c|c|c|c|}
\hline & \multicolumn{5}{|c|}{$\mathbf{T 1}$} & \multicolumn{7}{|c|}{$\mathbf{T} 2$} \\
\hline & $\mathbf{M}$ & DP & Mdn & Mín & Máx & $\mathbf{M}$ & DP & Mdn & Mín & Máx & $\mathbf{Z}$ & $\mathbf{P}$ \\
\hline DS & 61,8 & 9,4 & 64,0 & 48,0 & 72,0 & 54,9 & 7,1 & 54,0 & 44,0 & 66,0 & $-3,2$ & 0,001 \\
\hline OV & 56,6 & 7,4 & 57,0 & 42,0 & 68,0 & 52,3 & 4,6 & 52,0 & 45,0 & 61,0 & $-2,4$ & $\mathbf{0 , 0 1 7}$ \\
\hline IM & 52,6 & 11,8 & 55,0 & 30,0 & 73,0 & 56,5 & 7,8 & 58,0 & 46,0 & 71,0 & $-1,8$ & 0,068 \\
\hline AU & 53,2 & 11,7 & 57,0 & 30,0 & 68,0 & 55,6 & 11,7 & 58,0 & 27,0 & 71,0 & $-1,7$ & 0,087 \\
\hline $\mathbf{A L}$ & 57,3 & 13,1 & 60,0 & 37,0 & $\mathbf{7 7 , 0}$ & 53,3 & 8,7 & 52,0 & 36,0 & 69,0 & $-2,1$ & $\mathbf{0 , 0 3 5}$ \\
\hline $\mathbf{A} \mathbf{M}$ & 57,2 & 10,5 & $\mathbf{5 8 , 0}$ & 35,0 & 68,0 & 52,1 & 5,6 & 52,0 & 44,0 & 64,0 & $-2,2$ & $\mathbf{0 , 0 3 1}$ \\
\hline RT & 53,1 & 8,2 & 53,0 & 40,0 & 67,0 & 54,1 & 10,0 & 53,0 & 37,0 & 72,0 & $-0,9$ & 0,343 \\
\hline AS & 56,4 & 7,1 & 57,0 & 40,0 & 67,0 & 56,5 & 8,4 & 57,0 & 37,0 & 70,0 & $-0,2$ & 0,812 \\
\hline REP & 51,1 & 8,3 & 50,0 & 40,0 & 67,0 & 51,9 & 10,7 & 54,0 & 35,0 & 75,0 & $-0,7$ & 0,475 \\
\hline NEG & 45,2 & 8,9 & 47,0 & 33,0 & 63,0 & 47,0 & 8,7 & 47,0 & 30,0 & 62,0 & $-1,7$ & 0,095 \\
\hline IA & 60,1 & 8,6 & 63,0 & 43,0 & 74,0 & 61,5 & 8,1 & 62,0 & 48,0 & 80,0 & $-1,8$ & 0,077 \\
\hline $\mathrm{TC}$ & 56,7 & 13,0 & 60,0 & 35,0 & 80,0 & 56,8 & 11,4 & 57,0 & 41,0 & 77,0 & $-0,2$ & 0,850 \\
\hline TOD & 49,9 & 9,7 & 53,0 & 30,0 & 65,0 & 49,3 & 8,1 & 50,0 & 32,0 & 60,0 & $-0,4$ & 0,689 \\
\hline
\end{tabular}

Nota: em negrito, as escalas que diferiram significativamente $(\mathrm{p}<0,05)$.

Focalizando os adolescentes que no T1 não haviam revelado delitos violentos e, no $\mathrm{T} 2$, revelaram (grupo NV-V), nota-se que, em termos condutuais, os adolescentes passaram a revelar uma diversidade maior de delitos no T2 (Mdn aumentou de 3 para 5; p < 0,05), mas a diferença na frequência de delitos entre T1 e T2 não foi estatisticamente significativa, como mostra a Tabela 4.29.

Tabela 4.29

Comparação dos escores do grupo $N V-V(n=7)$ com ele mesmo em relação à diversidade de atos divergentes e diversidade e frequência anual de delitos - teste de Wilcoxon

\begin{tabular}{|c|c|c|c|c|c|c|c|c|c|c|c|c|}
\hline \multirow[b]{2}{*}{ DELITOS } & \multicolumn{5}{|c|}{ T1 } & \multicolumn{7}{|c|}{$\mathbf{T 2}$} \\
\hline & $\mathbf{M}$ & $\overline{\text { DP }}$ & Mdn & Mín & Máx & $\mathbf{M}$ & DP & Mdn & Mín & Máx & $\overline{\mathbf{Z}}$ & p \\
\hline Diversidade & 2,7 & 2,0 & 3 & $\mathbf{0}$ & 6 & 5,1 & 1,7 & 5 & 3,0 & 8,0 & $-2,2$ & $\mathbf{0 , 0 3}$ \\
\hline Frequência & 24 & 32 & 2 & 0 & 71 & 21,9 & 37,7 & 6 & 2,0 & 105 & $-1,2$ & 0,24 \\
\hline
\end{tabular}

Nota: em negrito, as escalas que diferiram significativamente $(\mathrm{p}<0,05)$. 
A tabela 4.30 mostra as pontuações obtidas pelos adolescentes do grupo NV-V no IJ$\mathrm{R}-\mathrm{Br}$, sendo que em nenhuma das comparações foi identificado diferenças estatisticamente significativas.

Tabela 4.30

Comparação dos escores do grupo $\mathrm{NV}-\mathrm{V}(n=7)$ com ele mesmo nas escalas do IJ-R-Brteste de Wilcoxon

\begin{tabular}{|c|c|c|c|c|c|c|c|c|c|c|c|c|}
\hline & \multicolumn{5}{|c|}{ T1 } & \multicolumn{7}{|c|}{$\mathbf{T 2}$} \\
\hline & $\mathbf{M}$ & DP & Mdn & Mín & Máx & $\mathbf{M}$ & $\mathbf{D P}$ & Mdn & Mín & Máx & $\mathbf{Z}$ & $\mathbf{p}$ \\
\hline DS & 53,4 & 18,2 & 50,0 & 34,0 & 72, & 60,3 & 8,1 & 9,0 & 51,0 & 74,0 & $-1,2$ & 0,237 \\
\hline $\mathrm{OV}$ & 51,9 & 13,5 & 4,0 & 30,0 & 68, & 54,1 & 11,4 & 52,0 & 43,0 & 76,0 & $-0,5$ & 0,612 \\
\hline IM & 53,0 & 16,2 & 3,0 & 35,0 & 73,0 & 51,4 & 12,9 & 48,0 & 34,0 & 66,0 & $-0,8$ & 0,396 \\
\hline $\mathrm{AU}$ & 48,6 & 13,6 & 47,0 & 30,0 & 70,0 & 48,6 & 13,5 & 45,0 & 35,0 & 73,0 & $-0,2$ & 0,833 \\
\hline $\mathrm{AL}$ & 53,6 & 20,1 & 43,0 & 33,0 & 77,0 & 54,1 & 17,3 & 44,0 & 38,0 & 77,0 & $-0,4$ & 0,674 \\
\hline $\mathrm{AM}$ & 50,3 & 16,3 & 48,0 & 28,0 & 70,0 & 55,3 & 7,5 & 53,0 & 42,0 & 64,0 & $-1,2$ & 0,248 \\
\hline RT/DEP & 52,4 & 14,7 & 57,0 & 30,0 & 67,0 & 51,7 & 16,0 & 58,0 & 32,0 & 72,0 & $-0,3$ & 0,733 \\
\hline AS & 54,7 & 10,5 & 57,0 & 37,0 & 63,0 & 54,7 & 11,9 & 56,0 & 38,0 & 70,0 & $-0,2$ & 0,865 \\
\hline REP & 55,4 & 4,6 & 55,0 & 50,0 & 60,0 & 55,1 & 7,1 & 56,0 & 46,0 & 66,0 & $-0,1$ & 0,916 \\
\hline NEG & 47,9 & 12,0 & 43,0 & 33,0 & 63,0 & 52,1 & 11,8 & 56,0 & 36,0 & 67,0 & $-1,8$ & 0,071 \\
\hline IA & 57,0 & 14,9 & 60,0 & 36,0 & 80,0 & 57,0 & 12,2 & 55,0 & 44,0 & 82,0 & $-0,2$ & 0,866 \\
\hline $\mathrm{TC}$ & 47,9 & 12,9 & 50,0 & 25,0 & 65,0 & 48,3 & 9,4 & 52,0 & 31,0 & 60,0 & $-0,7$ & 0,497 \\
\hline TOD & 41,9 & 7,9 & 45,0 & 30,0 & 50,0 & 41,9 & 9,3 & 45,0 & 27,0 & 54,0 & $-0,1$ & 0,916 \\
\hline
\end{tabular}

Em relação às escalas do QCJ, os adolescentes aumentaram as pontuações em Valores Antissociais (Mdn subiu de 0,4 para 0,8; p =0,011) e em Problemas com a Polícia e a Justiça (Mdn subiu de 2,5 para 2,9; $\mathrm{p}=0,046$ ) (Tabela 4.31).

De modo geral, pode-se dizer que as alterações significativas nos escores do T1 ao T2 foram positivas para o grupo V-NV e negativa para o grupo NV-V. A única exceção refere-se aos dados relacionados à diversidade de delitos autorrevelados, que aumentaram nos dois casos. Também se observa, tendo como parâmetro a quantidade de escalas que indicaram diferenças estatísticas significativas, quando se comparou os GNV e GV anteriormente, que poucas mudanças foram significativas. Quanto a este aspecto, frisa-se o diminuto número de 
participantes em cada grupo, especialmente no $\mathrm{NV}-\mathrm{V}$, condição que tende a fornecer evidências menos robustas relativa à realidade investigada.

Tabela 4.31

Comparação dos escores do grupo $N V$ - $V(n=7)$ com ele mesmo nas escalas do QCJ-teste de Wilcoxon

\begin{tabular}{|c|c|c|c|c|c|c|c|c|c|c|c|c|}
\hline & \multicolumn{5}{|c|}{ T1 } & \multicolumn{7}{|c|}{$\mathbf{T 2}$} \\
\hline & $\mathbf{M}$ & DP & Mdn & Mín & Máx & $\mathbf{M}$ & DP & Mdn & Mín & Máx & $\mathbf{Z}$ & $\mathbf{p}$ \\
\hline Impulsividade & 1,4 & 1,0 & 1,6 & 0,0 & 4,0 & 1,3 & 1,0 & 1,7 & 0,0 & 5,0 & $-0,4$ & 679 \\
\hline Valores antissociais & $\mathbf{0 , 1}$ & $\mathbf{0 , 0}$ & 0,4 & $\mathbf{0 , 0}$ & 1,0 & 1,4 & 1,0 & $\mathbf{0 , 8}$ & 1,0 & 3,0 & $-2,5$ & ,011 \\
\hline Atitude violenta & 0,9 & 0,0 & 1,2 & 0,0 & 3,0 & 1,6 & 1,0 & 1,4 & 0,0 & 4,0 & $-1,4$ &, 157 \\
\hline Valores escolares & 2,0 & 2,0 & 0,0 & 2,0 & 2,0 & 1,3 & 2,0 & 1,0 & 0,0 & 2,0 & $-1,6$ &, 102 \\
\hline Repetições na escola & 2,0 & 2,0 & 1,4 & 0,0 & 4,0 & 2,4 & 3,0 & 1,1 & 1,0 & 4,0 & $-0,8$ & ,453 \\
\hline Suspensão da escola & 4,3 & 1,0 & 9,2 & 0,0 & 25,0 & 3,0 & 1,0 & 3,3 & 1,0 & 10,0 & $-0,7$ & ,492 \\
\hline Pares infratores & 6,1 & 8,0 & 3,3 & 1,0 & 9,0 & 6,1 & 8,0 & 3,7 & 1,0 & 10,0 & 0,0 & 1,00 \\
\hline $\begin{array}{l}\text { Violência no bairro } \\
\text { Problemas com a }\end{array}$ & 2,1 & 2,0 & 1,3 & 0,0 & 4,0 & 1,1 & 1,0 & 1,2 & 0,0 & 3,0 & $-1,9$ & 059 \\
\hline Polícia e a Justiça & 4,9 & $\mathbf{5 , 0}$ & 2,5 & 2,0 & 8,0 & 4,3 & 4,0 & 2,9 & 1,0 & 8,0 & $-2,0$ &, 046 \\
\hline
\end{tabular}

Por fim, as tabelas 4.32 e 4.33 mostram os resultados das análises de regressão e do teste dos modelos para predizer a conduta delituosa violenta. A tabela 4.30 mostra que as variáveis selecionadas pelo método Forward Conditional explicam $62 \%$ da variância na variável dependente, enquanto o modelo formado pelo método Insert explica 54\%. Nos dois casos, o teste de Omnibus para os coeficientes do modelo identificou significância estatística $(\mathrm{p}<0,001)$.

Tabela 4.32

Modelo de Regressão Logística para a emissão de delito violento

95\% I.C. $\operatorname{EXP}(B)$

B S.E. Wald O.R.

Variàveis incluídas

Inf. Sup.

*Modelo 1: método forward conditional

\begin{tabular}{lcccccc} 
Ato violento $(0 / 1)$ & 2,77 & 1 & 8 & 16,03 & 2 & 106 \\
$\mathrm{DS}>60(0 / 1)$ & 1,44 & 1 & 3 & 4,24 & 1 & 24 \\
$\mathrm{AS}>60(0 / 1)$ & 2,95 & 1 & 6 & 19,14 & 2 & 196 \\
$\mathrm{NEG}>60(0 / 1)$ & 3,09 & 2 & 4 & 21,87 & 1 & 446 \\
Pares infratores & 0,39 & 0 & 4 & 1,48 & 1 & 2 \\
Constante & $-6,36$ & 2 & 9 & 0,00 & & \\
\hline
\end{tabular}




\begin{tabular}{lcccccc}
\hline **Modelo 2: método insert & & & & & & \\
Ato violento $(0 / 1)$ & 2,94 & 1 & 9 & 18,90 & 3 & 124 \\
DS $>60(0 / 1)$ & 0,67 & 1 & 1 & 1,96 & 0 & 11 \\
TC $>50(0 / 1)$ & 1,98 & 1 & 3 & 7,27 & 1 & 81 \\
Atraso escolar (em anos) & 0,31 & 0 & 2 & 1,36 & 1 & 2 \\
Pares infratores & 0,39 & 0 & 0 & 1,00 & 1 & 1 \\
Constante & $-3,75$ & 1 & 9 & 0,02 & & \\
\hline
\end{tabular}

$*$ Modelo 1: $X^{2}(5)=34, \mathrm{p}<0.001 ; \mathrm{R}^{2}$ de Nagelkerke $=62 \% ;$ Acurácia $=85 \%(\mathrm{~S}=75 \% ; \mathrm{E}=94 \%) . * *$ Modelo 2: $X^{2}(5)=29, \mathrm{p}<0.001 ; \mathrm{R}^{2}$ de Nagelkerke $=55 \% ;$ Acurácia $=80 \%(\mathrm{~S}=67 \% ; \mathrm{E}=90 \%)$.

Finalmente, a tabela 4.33 mostra as probabilidades de cada adolescente cometer delitos violento no T2, calculadas pelos modelos com base nas Equações 4.1 e 4.2, respectivamente.

\section{Equação 4.1. Fórmula utilizada pelo modelo 1}

$$
\frac{1}{1+e^{(-(-6,36+(2,77 * X 1)+(1,44 * X 2)+(2,95 * X 3)+(3,09 * X 4)+(0,39 * X 5)))))}}
$$

Onde $X_{1}=$ Ato violento, $X_{2}=$ DS maior que $60, X_{3}=$ AS maior que $60, X_{4}=$ Neg maior que 60 e $X_{5}=$ pontuação na escala de pares infratores.

\section{Equação 4.2. Fórmula utilizada pelo modelo 2}

$$
\frac{1}{1+e^{(-(-3,75+(2,94 * X 1)+(0,67 * X 2)+(1,98 * X 3)+(0,31 * X 4)+(0,001 * X 5)))))}}
$$

Onde $X_{1}=$ Ato violento, $X_{2}=$ DS maior que $60, X_{3}=$ TC maior que 50, $X_{4}=$ atraso escolar em anos e $X_{5}=$ pontuação na escala de pares infratores.

A acurácia do modelo 1 foi de $74 \%$, sendo $70 \%$ de sensibilidade e $77 \%$ de especificidade (área sob a curva $=0,70$ ). A acurácia do modelo 2 foi de $83 \%$, sendo $90 \%$ de sensibilidade e $77 \%$ de especificidade (área sob a curva $=0,78$ ). 
Tabela 4.33

Acurácia dos modelos 1 e 2 para predizer a prática de delito violento no T2

\begin{tabular}{|c|c|c|c|c|c|c|c|}
\hline \multirow[b]{2}{*}{ Participante } & \multirow[b]{2}{*}{$\begin{array}{l}\text { Violência } \\
\text { (T2) }\end{array}$} & \multicolumn{3}{|c|}{ Modelo 1} & \multicolumn{3}{|c|}{ Modelo 2} \\
\hline & & $\mathbf{P}(\mathbf{V})$ & Predição & Acertou? & $\mathbf{P}(\mathbf{V})$ & Predição & Acertou? \\
\hline 1 & Não & 0,02 & NV & Sim & 0,06 & NV & Sim \\
\hline 2 & Não & 0,01 & NV & Sim & 0,08 & NV & Sim \\
\hline 3 & Sim & 0,99 & $\mathrm{~V}$ & Sim & 0,75 & V & Sim \\
\hline 4 & Não & 0,01 & NV & Sim & 0,03 & NV & Sim \\
\hline 5 & Não & 0,14 & NV & Sim & 0,10 & NV & Sim \\
\hline 6 & Não & 0,34 & $\mathrm{NV}$ & Sim & 0,18 & $\mathrm{NV}$ & Sim \\
\hline 7 & Não & 0,00 & NV & Sim & 0,03 & NV & Sim \\
\hline 8 & Não & 0,01 & $\mathrm{NV}$ & Sim & 0,04 & $\mathrm{NV}$ & Sim \\
\hline 9 & Não & 0,99 & $\mathrm{~V}$ & Não & 0,14 & NV & Sim \\
\hline 10 & Sim & 0,00 & NV & Não & 0,04 & NV & Não \\
\hline 11 & Sim & 0,73 & $\mathrm{~V}$ & Sim & 0,25 & $\mathrm{NV}$ & Não \\
\hline 12 & Sim & 0,99 & V & Sim & 0,94 & V & Sim \\
\hline 13 & Não & 0,75 & V & Não & 0,68 & V & Não \\
\hline 14 & Sim & 0,80 & V & Sim & 0,97 & V & Sim \\
\hline 15 & Não & 0,87 & V & Não & 0,39 & $\mathrm{NV}$ & Sim \\
\hline 16 & Sim & 1,00 & $\mathrm{~V}$ & Sim & 0,90 & V & Sim \\
\hline 17 & Não & 0,01 & NV & Sim & 0,30 & NV & Sim \\
\hline 18 & Não & 0,35 & NV & Sim & 0,39 & NV & Sim \\
\hline 19 & Sim & 0,10 & NV & Não & 0,62 & V & Sim \\
\hline 20 & Sim & 0,90 & $\mathrm{~V}$ & Sim & 0,92 & V & Sim \\
\hline 21 & Sim & 1,00 & V & Sim & 0,92 & V & Sim \\
\hline 22 & Sim & 0,00 & NV & Não & 0,02 & NV & Não \\
\hline 23 & Não & 0,19 & NV & Sim & 0,10 & $\mathrm{NV}$ & Sim \\
\hline & & & Acurácia: & 0,74 & & Acurácia: & 0,83 \\
\hline & & & ssibilidade: & 0,70 & & nsibilidade: & 0,90 \\
\hline & & Esl & ecificidade: & 0,77 & Es & ecificidade: & 0,77 \\
\hline
\end{tabular}

Nota: $\mathrm{P}(\mathrm{V})=$ probabilidade de cometer delito violento no $\mathrm{T} 2$. 


\subsection{Discussão}

O presente estudo buscou identificar as principais variáveis associadas à conduta delituosa violenta na adolescência e, mais especificamente, ao desenvolvimento desta conduta, investigando adolescentes em conflito com a lei brasileira em dois momentos (T1 e T2), com um intervalo de tempo médio de 18 meses. Apesar da perda de $34 \%$ da amostra do T1 ao T2, foi possível acompanhar 78 adolescentes e verificar o impacto de alterações psicossociais no comportamento antissocial manifestado, incluindo a conduta delituosa violenta.

Boa parte dos adolescentes estudados, no momento inicial da pesquisa (T1), havia sido processada em razão de delitos relativos à venda ou à posse de drogas ilícitas (47\%). Tomando por base os dados de delinquência autorrevelada, as porcentagens de adolescentes que revelaram a participação nesse tipo de delito nos dois momentos da investigação seriam ainda maiores, $87 \%$ em T1 e $94 \%$ em T2.

Vale notar que os delitos relacionados às drogas ilícitas, classificados como nãoviolentos no presente estudo (levando em conta os critérios adotados), é o mais frequentemente cometido pelos adolescentes em conflito com a lei, no Brasil, de acordo com os dados do Cadastro Nacional de Adolescentes em Conflito com a Lei. Só em 2018, mais de 50 mil guias por ato infracional de Tráfico de Drogas atribuídos a adolescentes foram expedidas. Diante desse cenário, é possível dizer que a delinquência juvenil oficial se atrela mais preponderantemente a atos não-violentos. Aliás, essa problemática representa de $20 \%$ a $30 \%$ da criminalidade brasileira. Assim, será importante entender, em pesquisas futuras, as motivações pessoais e as necessidades sociais, associadas a esse tipo de delito, assim como o contexto sociocultural no qual esses atos se manifestam, para elucidar as razões pelas quais é o delito mais frequente no país e pensar as formas de lidar com essa realidade. A discussão sobre a descriminalização e a regulamentação de uso de algumas drogas têm se intensificado nos últimos anos, e esse debate deve acontecer de forma séria e compromissada socialmente, uma vez que a criminalização não parece se apresentar mecanismo eficaz no controle deste tipo de crime. É fato que o crime de "tráfico de drogas" se mostra muitas vezes associado a outros, esses sim violentos. Em estudo realizado nos Estados Unidos, Gavrilova, Kamada e Zoutman (2017) identificaram que a regularização da maconha em estados próximos ao México se fez acompanhar da redução na taxa de crimes violentos, possivelmente, segundo os autores, em razão da do abalo deste fato no financiamento de organizações criminosas. 
De todo modo, os delitos classificados como violentos, de acordo com os critérios do presente estudo, compuseram o segundo conjunto de condutas mais frequentes na amostra estudada no T1 (23,5\%, distribuídos entre ameaça, roubo, lesão corporal, latrocínio e homicídio). Em relação aos delitos violentos autorrevelados, levando em conta as modalidades pesquisadas, verificou-se que a proporção de adolescentes que os revelaram, em T1, foi de 54\% (roubo), rixa (33\%), lesão corporal com uso de instrumentos (33\%) e lesão corporal (11\%) e, em T2, foi de 51\% (roubo), 47\% (rixa), 33\% (lesão corporal com uso de instrumentos) e 5\% (lesão corporal). A quantidade de vezes em que esses atos teriam sido realizados ao longo do último ano antes de cada entrevista representou $13 \%$ em T1 e $8 \%$ em T2, do total de delitos, denotando, em efeito, a baixa proporção desse tipo de delitos praticados pelos mesmos.

Com base nesses números, nota-se que a frequência relativa em que os adolescentes são apreendidos por delitos violentos é maior que a frequência relativa em que esses delitos são cometidos. De modo inverso, outros delitos, como o Porte Ilegal de Arma de Fogo, classificado no presente estudo como delito não-violento, chamou a atenção, pois correspondeu a 19\% (em T1) e a 14\% (em T2) do total de delitos revelados pelos participantes, mas a apenas $1 \%$ dos delitos pelos quais foram apreendidos. Assim, pode-se dizer que a representatividade de cada modalidade de delito no Sistema de Justiça Juvenil varia de acordo com sua natureza, evidenciando aspectos da reação social do delito e da probabilidade de apreensão de cada ato delituoso. Dentro disto, a delinquência juvenil retratada pelos dados oficiais é substancialmente diferente da retratada pelas informações autorreveladas, ressaltando, conforme apontam Thornberry e Krohn (2000), que o método de obtenção dos dados determina como a realidade será apreendida.

Portanto, considerando os dados do autorrelato como mais condizentes com àqueles que descrevem, aproximadamente, a efetiva trajetória da conduta delituosa dos adolescentes investigados, destaca-se que eles permitiram apreender um engajamento infracional significativo, na amostra, levando em conta as variáveis indicativas idade de início, diversidade e frequência de delitos praticados. Os dados médios nessas variáveis do engajamento infracional indicaram que eles apresentariam trajetórias que remetem majoritariamente a uma delinquência distintiva/persistente. Os adolescentes revelaram, já no $\mathrm{T} 1$, ter praticado o primeiro delito aos 11,6 anos, em média, idade situada em período de transição entre o final da infância e o início da adolescência. Esta idade média pode ser considerada precoce, semelhante à encontrada em estudos com outras amostras de adolescentes infratores, do mesmo contexto sociocultural (Bono, Komatsu \& Bazon, 2019; 
Komatsu \& Bazon, 2017a). Sabe-se que quanto mais precoce a idade de início da participação em atividades delituosas, mais provável a estabilização da conduta no repertório comportamental do indivíduo, o que propicia a persistência da conduta delituosa no tempo e, também, mais provável sua diversificação (em termos de experimentação de modalidades diferentes de delitos) e, com isso, a emissão de delitos violentos (Le Blanc, 2002). Quanto à diversidade de delitos distintos praticados, em T1, os jovens revelaram em média 5,9 delitos diferentes (de um total de 13 possíveis/investigados), sendo, a essa altura, 1,3 violentos (de 4 possíveis/investigados). A frequência média com a qual esses delitos teriam sido praticados nos 12 meses anteriores à coleta de dados seria de 53,7. Esses dados mostram que a delinquência retratada pelo autorrelato difere significativamente da delinquência oficial em termos de magnitude, sendo a delinquência autorrevelada muito mais frequente que a delinquência oficial, como era esperado.

Tratando a amostra de adolescentes como um todo, ainda, em termos de exposição aos fatores de risco e de proteção investigados, verificou-se que ela apresentou, em geral, pontuação nos instrumentos empregados indicativa de maior risco e de menor proteção em relação aos parâmetros da população normativa. Destacando o uso de substâncias psicoativas, avaliado por meio de questões específicas do QCJ, observou-se que praticamente todos os adolescentes relataram já ter experimentado álcool (90\%) e alguma droga ilícita (92\%). Esse dado mostra o quanto o uso de álcool e outras drogas é difundido em meio aos adolescentes infratores em geral, representando uma problemática que perpassa a trajetória da conduta delituosa de muitos.

Com relação aos fatores atinentes a variáveis pessoais, avaliados especificamente pelo IJ-R-Br, observou-se que os escores médios nas escalas mostram que a maioria dos adolescentes estudados possuía, quando foram avaliados pela primeira vez (T1), pontuações de pelo menos um desvio-padrão em relação à população normativa nas escalas Desadaptação Social, Alienação e Índice de Associabilidade (Mdn > 60). A pontuação elevada nessas escalas indicaria, entre outros aspectos, adolescentes apresentando significativa orientação antissocial, característica que em geral discrimina adolescentes apresentando uma delinquência distintiva (com engajamento infracional significativo) de adolescentes apresentando uma delinquência comum (Costa, Komatsu \& Bazon, 2019). No T2, as pontuações nessas escalas diminuíram no sentido de apontar uma atenuação da orientação antissocial, o que pode ser explicado pelo curso do desenvolvimento psicológico, o que é compatível com apontamentos da literatura sobre a delinquência juvenil de um ponto de vista desenvovlimental (Monahan, Steinberg, Cauffman \& Mulvey, 2013). Reitera-se que os 
aspectos avaliados pelo Inventário, que permitem aferir tal orientação, são dinâmicos, por definição, tendendo, portanto, a sofrer alterações com o avanço da idade, sendo que este ajuste explica, para alguns, o abandono das atividades delituosas, ou seja, o fenômeno da desistência conforme mostram outros estudos longitudinais (Farrington et al., 2006; Le Blanc, 2003).

Focalizando, agora, o fenômeno da delinquência distintiva violenta, objeto principal de interesse do presente estudo, destaca-se primeiramente, que os resultados obtidos pelas comparações entre os grupos (GNV e GV) dependem do critério de formação dos grupos utilizado - formados com base nas informações oficiais versus formados com base nas informações autorreveladas, tanto no T1 quanto no T2. As comparações mostraram que os grupos formados a partir das informações oficiais, tanto em T1 quanto em T2, não indicaram diferenças nas escalas dos instrumentos empregados para avaliar os adolescentes em termos psicossociais, revelando que a classificação dos adolescentes em violentos e não-violentos baseada neste tipo de informação se aproxima da aleatoriedade. As comparações feitas entre grupos formados a partir do dado de autorrelato, tanto em T1 quanto em T2, contrariamente, indicaram uma quantidade importante de variáveis de natureza pessoal e social discriminando os indivíduos, associando-se, portanto, à conduta violenta autorrevelada.

As comparações entre GNV e GV, compostos com base na informação autorrevelada, mostram que os adolescentes do GV teriam começado a praticar delitos mais cedo, sendo seu comportamento delituoso mais diversificado e também mais frequente (cinco vezes maior que no GNV). A idade de início, a diversidade e a frequência de delitos são variáveis que revelam o nível de engajamento infracional dos adolescentes. Adicionalmente, a violência também consiste em um aspecto significativo do engajamento infracional; assim, é coerente que os infratores violentos se caracterizem por apresentar uma atividade delituosa mais precoce, mais diversificada e mais frequente. No T2, essas diferenças se mantiveram, com exceção da diversidade de delitos violentos. Essa variável pode ter deixado de discriminar os grupos devido aos adolescentes que faziam parte do GV, no T1, e passaram ao GNV no T2, ou seja, passaram a compor o GNV sem, contudo, deixarem de possuir um delito violento em seus históricos comportamentais.

Em relação às variáveis psicossociais, as comparações entre GNV e GV mostraram que esses eram diferentes, já nesse ponto do tempo - quando tinham em média 17,8 anos de idade, em padrão de comportamento e nas seguintes variáveis psicossociais: Valores Antissociais, Atitude Violenta, Oposição a Figuras de Autoridade, Problemas com a Polícia e a Justiça, Apego Parental, Supervisão Parental, Escola Desorganizada, Bom Desempenho 
Acadêmico, Problemas de Comportamento em Contexto Escolar, Rotina Desestruturada, Pares Infratores, Percepção de Violência e de Criminalidade no Bairro e Controle Formal no Bairro. No T2, as comparações entre GNV e GV denotam diferenças significativas nas seguintes variáveis: Atitude Violenta, Oposição a Figuras de Autoridade, Escola Desorganizada, Pares Infratores e Percepção de Violência e Criminalidade no Bairro. Dessa forma, pode-se pensar que as variáveis relevantes identificadas no T1 são, temporalmente, mais ligadas à manifestação de condutas violentas na adolescência, enquanto que as variáveis que permaneceram distintas no T2 podem estar associadas à manutenção da conduta violenta na vida adulta. Em concordância com o que foi abordado no capítulo 2, o modo como as variáveis afetam o indivíduo difere de acordo com seu estágio de desenvolvimento psicossocial e com os períodos de transições significativos - como o da adolescência à vida adulta, podendo diminuir ou aumentar sua intensidade ou começar ou deixar de ter efeito a depender da fase da vida.

Sublinha-se que no âmbito dos aspectos pessoais, no T1, o GV apresentou maiores pontuações em Valores Antissociais, Atitudes Violentas, Oposição a Figuras de Autoridade e Problemas com a Polícia e a Justiça. Era esperado que o GV apresentasse mais atitudes violentas e, consequentemente, que indicasse envolvimento em mais situações de conflitos com figuras de autoridade, incluindo a Polícia e a Justiça. Todavia, esperava-se que em termos de valores antissociais os grupos se equiparassem, dado que ambos são compostos por adolescentes infratores apresentando uma delinquência distintiva. Os resultados sugerem que há diferenças qualitativas e quantitativas entre os grupos, no qual os valores antissociais consistiriam em um aspecto quantitativo que faz o GV pontuar mais que o GNV, por serem mais engajados de forma geral, embora este não necessariamente seja um fator que explique o engajamento em condutas violentas.

No T2, apenas as escalas de Atitude Violenta e Oposição a Figuras de Autoridade discriminaram os grupos no domínio pessoal, sendo que as demais escalas, teoricamente menos relacionadas com a violência, perderam força com o início da vida adulta. Ainda no plano pessoal, destaca-se que a escala de Impulsividade do QCJ não discriminou os grupos, nem em T1 e nem em T2, ao contrário do que se esperava por representar um aspecto de baixo autocontrole. A estratégia de avaliar as Funções executivas no T2, contudo, evidenciaram dois aspectos relevantes: a) os jovens investigados, independentemente do grupo, teriam em média mais dificuldades que jovens da população, na mesma faixa etária, tendo cometido mais erros no cartão 3 do Teste de Stroop (TS-V) e maior quantidade de movimentos extras no teste Torre de Londres (TOL) que a população normativa de 
adolescentes de escola pública (Komatsu, Santos \& Bazon, 2019); b) os jovens alocados em GV teriam em média mais dificuldade que os alocados em GNV, apresentando mais erros no cartão 3 do TS-V e maior quantidade de movimentos extras no TOL. O desempenho no TS-V é um indicativo das capacidades de atenção seletiva, flexibilidade cognitiva e controle inibitório; e o desempenho no TOL avalia as habilidades de planejamento e resolução de problemas (Strauss et al., 2006). Ambos estão associados a medidas de impulsividade/falta de controle e prejuízos nas funções de autorregulação, denotando que os jovens infratores e especialmente aqueles apresentando condutas violentas, neste momento, teriam significativamente mais prejuízos nessas funções. O fato de os participantes apresentarem essas diferenças nas tarefas executivas, mas não se distinguirem na escala de Impulsividade do QCJ, pode dever-se às características dos instrumentos utilizados. Considerando o tipo de questão do QCJ, a ausência de diferença (uma vez que era esperada), pode decorrer da dificuldade dos próprios adolescentes/jovens em reconhecerem e em relatarem suas dificuldades em tarefas que exigem atenção e autocontrole no dia a dia, algo que não ocorre em uma medida de desempenho, ainda que simples, como os testes de Stroop e das Torres de Londres.

No âmbito dos aspectos sociais, destaca-se que, no domínio familiar, GV pontuou mais baixo que GNV, no T1, em duas escalas de proteção: Apego Parental e Supervisão Parental. A supervisão adequada proporcionada pelos pais/cuidadores, ancorada em relações afetivas fortes, funciona como proteção ao engajamento infracional geral (Dib, Komatsu \& Bazon, 2019; Le Blanc, 1997) e, aparentemente, ao engajamento em conduta violentas também, na adolescência. Assim, em alguma medida esperava-se uma não diferenciação entre os grupos nessas variáveis por serem fatores de risco para a delinquência geral. No T2, nenhuma das escalas no âmbito familiar discriminou os grupos. Esses aspectos que antes distinguiam os grupos podem efetivamente ter seus impactos reduzidos, na regulação da conduta, com passagem do tempo, devido ao ingresso na etapa da vida adulta, em virtude de significativas transformações sociais e relacionais, com a relativa independência dos pais/cuidadores e o eventual estabelecimento de relacionamento conjugal próprio (Catalano \& Hawkins, 1996; Sampson \& Laub, 2005). Nesse ponto, será importante que os instrumentos de pesquisa, em investigações futuras, busquem verificar a existências de vínculos não apenas em relação aos pais/cuidadores, mas a também a outras figuras de apoio.

No domínio escolar, três escalas do QCJ distinguiram os grupos no T1: Escola Desorganizada/Deteriorada, Problemas de Comportamento e Bom Desempenho Acadêmico, nas quais o GV pontuou mais alto em todas. Os adolescentes do GV perceberiam suas escolas 
como mais desorganizadas, em termos de indisciplina, de prática de delitos em seu interior e de degradação física, reiterando uma imagem que, no geral, representa uma visão bastante negativa do ambiente escolar, algo muito comum em meio a adolescentes infratores, e que muitas vezes antecede a evasão da escola (Silva, Cianflone \& Bazon, 2016). Os adolescentes do GV também indicaram ter, mais frequentemente, histórico de problema de comportamento em contexto escolar, assinalados por meio de sanções como suspensões e expulsões, o que também contribuiria para compor o conjunto de experiências negativas/estressantes em contexto escolar. Inusitadamente, apesar destes aspectos negativos mencionados, os adolescentes do GV responderam às questões atinentes ao desempenho acadêmico de modo a indicar que se perceberiam com melhor desempenho, comparando-se aos alunos de sua turma, que os adolescentes do GNV. É certo que a diferença encontrada, neste sentido, não era esperada, mas é possível que esta se deva mais propriamente a vieses de subjetividade, considerando que a aferição do desempenho acadêmico deu-se tendo por base a percepção dos adolescentes. Nesse tocante, será importante que estudos futuros contemplem outras medidas do desempenho acadêmico, como as notas nas avaliações escolares e as aquisições efetivamente feitas pelos adolescentes.

No T2, o único aspecto que continuou distinguindo os grupos foi a percepção da desorganização e da deterioração, reiterando que a percepção negativa da escola persiste como aspecto relevante na problemática da implicação dos adolescentes / dos jovens em delinquência violenta, suscitando questões sobre o fato de a experiência escolar, à luz desta percepção, constituir-se em aspecto relevante para a predição do envolvimento dos adolescentes / dos jovens em condutas violentas. A irrelevância das outras variáveis atinentes à escola, no T2, talvez se deva ao fato de muitos dos jovens investigados, por ocasião da pesquisa, já terem concluído ou abandonado os estudos, com o consequente distanciamento do ambiente escolar e perda de significado das variáveis em questão (e, assim, de sua força de influência no comportamento).

No que concerne aos aspectos da Rotina e dos Pares de Idade, ambas as escalas Rotina Desestruturada e Pares Infratores - distinguiram significativamente GV e GNV, no T1. A rigor, não se esperava que as variáveis, especialmente rotina desestruturada, distinguisse os grupos, uma vez que ambas são, de forma geral, importantes fatores de risco para a delinquência. A Rotina desestruturada por que cria a oportunidade para os delitos; e a frequentação de pares infratores porque, além de também oportunizar a prática de delitos, produz socialização em valores e em atitudes antissociais (Catalano \& Hawkins, 1996; Le Blanc, 1997). No T2, diferentemente, somente afiliação a pares infratores continuou 
distinguindo GV de GNV, no sentido de indicar uma ligação mais importante dos jovens engajados em violência a pares de idade infratores, sublinhando a importância desta variável para as condutas agressivas na passagem da adolescência para a vida adulta. A frequentação / a afiliação dos jovens a pares infratores pode assumir diferentes contornos, podendo variar desde conhecer e gastar algum tempo do dia com eles, até integrar um grupo com orientação claramente criminal, uma gang ou organização criminosa (Sutherland, 1947; Vigil et al., 2004). A conduta delituosa violenta tem se mostrado mais fortemente associada ao pertencimento de adolescentes/ jovens a gangues/grupos criminalizados relativamente organizados que à mera frequentação de pares infratores (Lanctôt \& Le Blanc, 1996; Mora \& Decker, 2018; Vigil et al., 2004). Essa nuance relacionada ao tipo de ligação a pares infratores não é, contudo, focalizada nas questões do QCJ, impondo a necessidade de considerar tal aspecto em investigações futuras.

No tocante às comparações entre os dois grupos, nos dois tempos, tem-se que a variável no domínio Bairro/Comunidade - Percepção de Criminalidade e de Violência - os distinguiu tanto no T1 quanto no T2, com o GV pontuando mais alto que o GNV. É fato que uma medida da percepção da criminalidade e da violência na comunidade de residência não corresponde exatamente à medida das taxas desses fenômenos. Essa nuance na avaliação poderá ser levada em conta em investigações futuras. De todo modo, mediante os resultados obtidos é possível afirmar que aqueles que apreendem o próprio entorno sociocomunitário como mais criminalizado e mais violento parecem mais a risco de engajar-se em delitos violentos. Segundo a literatura, a exposição reiterada à atividade criminal e à violência, na comunidade, pode impactar o desenvolvimento do comportamento individual de diferentes maneiras. Como testemunha ou como vítima, a "convivência" em contextos marcados por altas taxas de criminalidade e de eventos violentos, oferece às crianças e aos adolescentes modelos desviantes, com quais poderão se identificar ou não, a depender de outras variáveis. Nesses contextos, fomentam-se atitudes antissociais ao gerar dessensibilização progressiva em relação ao uso da violência como forma de interagir e/ou resolver problemas (Mrug, Madan \& Windle, 2016; Tella, Freira, Gálvez, Schargrodsky, Shalom \& Sigman, 2017). No mais, sabe-se que a violência na comunidade gera estresse, e este também se constitui em fator de risco para o desenvolvimento de diversos problemas de comportamento (internalizantes e/ou externalizantes), os quais podem se constituir em fatores de risco para a delinquência e, especialmente, para a delinquência violenta.

Por fim, no âmbito das variáveis sociais, outra variável que diferenciou os grupos no T1, de forma inusitada, foi Controle Formal, uma vez que GNV pontuou significativamente 
mais alto, na escala, que GV. O controle formal, ou seja, o número de vezes em que o indivíduo é abordado pela polícia e/ou processado na justiça em razão de suas condutas, normalmente se liga, positivamente, à reiteração na conduta e, com isso, ao fomento a trajetórias de delinquência distintiva (Le Blanc, 1997). Em termos práticos, quanto mais um indivíduo é apreendido/processado, mais ele reitera na ação, provavelmente em razão de efeitos produzidos pela rotulação negativa (que implicam em maior vigilância e em diminuição de oportunidades de socialização positiva) (Farrington, 1977; Bernburg, Krohn \& Rivera, 2006). Ainda em termos práticos, o inverso também seria verdadeiro, ou seja, quanto mais um indivíduo reitera em atos delituosos, mais ele se arrisca a ser apreendido/processado, sobretudo em contexto com maior monitoramento ostensivo, geralmente observado em bairros/regiões com taxas elevadas de criminalidade (Mears, Stewart, Warren \& Simons, 2016). Posto isso, era de se esperar, mediante a caracterização dos padrões de conduta delituosa em função dos dados de autorrelato, nos dois grupos, que GV referisse mais "controle formal". Isso, todavia, não se verificou. Ademais, em T2, a escala deixou de diferenciar os grupos.

Focalizando aspectos estritamente psicológicos, tendo por base as variáveis (constructos) inerentes ao IJ-R-Br, sublinha-se que os grupos, no T1, se diferenciaram em sete das 13 escalas, o que mostra que os adolescentes cuja conduta remete a uma delinquência persistente que não envolve violência e uma que envolve violência apresentam muitas diferenças no plano das crenças, dos valores e das atitudes, atuando, segundo a teoria inerente ao próprio instrumento, na sustentação dos padrões de conduta. As escalas Imaturidade (Im), Alienação (Al), Retraimento/Depressão (Rt/Dep), Ansiedade Social (AS), Repressão (Rep) e Negação (Neg) não discriminaram GNV e GV, neste ponto do tempo. No T2, a diferença entre os dois grupos ampliou-se e modificou-se ligeiramente, verificando-se que GNV e GV passaram a se diferenciar em 11 das 13 escalas. Eles não apresentaram diferenças significativas apenas em Repressão (Rep) e no Índice de Associabilidade (IA). De forma geral, segundo a interpretação do instrumento, o grupo de adolescentes com prática de delitos violentos obteve pior desempenho nas escalas em que se constataram diferenças significativas. Destaca-se, contudo, que tanto no GV quanto no GNV, no T1 e no T2, há indivíduos cujas pontuações estão abaixo $(<40)$ e acima $(>60)$ dos parâmetros da população normativa da mesma faixa de idade, assim como há indivíduos com pontuação indicativa de um funcionamento normativo (>40 e <60). Nesse sentido, embora os adolescentes estejam homogeneamente agrupados em termos de não engajamento ou de engajamento em conduta 
violenta, no interior de cada grupo há também diferenças em relação ao funcionamento psicológico (alguns apresentando mais problemas que outros).

Considerando a definição dos constructos representados em cada escala, destaca-se primeiramente a Desadaptação Social (DS), que representa um conjunto de atitudes associadas a necessidades não atendidas, que definem a extensão com a qual o indivíduo partilha padrões adaptativos que demonstram inabilidade em atender, de maneira socialmente aceitável, as demandas do ambiente (Bazon, 2016). Os itens dessa escala representam crenças, atitudes e tendências comportamentais que favorecem a desconfiança e a hostilidade na relações interpessoais, como se pode observar nos seguintes exemplos: "Eu sinto raiva quando pessoas desonestas conseguem se livrar da justiça", "Eu me preocupo muito em fazer as coisas certas" (pontua quando falso), "É muito melhor não ter confiança em ninguém” e "Eu entro em muitas brigas". Assim, em termos relacionais, indivíduos com pontuações altas nesta escala tendem a apresentar inaptidão nas interações sociais, desconfiança e hostilidade em relação ao outro, dificuldades nas funções de controle dos impulsos e comportamentos agressivos (Jesness, 2003; Bazon, 2016; Santos, Komatsu \& Bazon, 2019). Dessa forma, faz sentido que GNV e GV tenham se diferenciado nessa escala, com GV apresentando escores médios mais altos, indicativos de mais problemas, nos tempos T1 e T2, como também a magnitude da diferença, nesta, tenha sido grande.

A segunda escala que descriminou os grupos, em T1 e em T2, foi Orientação de Valores (OV). Esta é composta por itens relacionados a crenças e atitudes favoráveis a (ou que naturalizam) comportamentos antissociais, conforme se nota no conteúdo de alguns dos itens que a avaliam: "A maioria das pessoas engana um pouco para conseguir dinheiro", " $A$ maioria dos policiais não é inteligente", "Não parece ser errado roubar de comerciantes desonestos". Nos estudos de validação, essa escala vem apresentando boa acurácia em discriminar adolescentes infratores de não infratores (Costa, Komatsu \& Bazon, 2017). Outros itens dessa escala referem-se à presença de inquietações, ansiedade, pensamentos estranhos e alienação social: "De vez em quando, eu tenho pensamentos diferentes e esquisitos na minha cabeça", "Eu sinto que meu coração bate mais rápido quando alguém não para de me fazer perguntas" e "Parece que quase sempre que eu me esforço para fazer a coisa certa, algo ruim acontece", "A maior parte do tempo eu não encontro nada para fazer". Ela ainda inclui itens cujos conteúdos se mostram mais fortemente relacionados a atitudes violentas: "Quando eu estou realmente com raiva, eu sou capaz de fazer qualquer coisa", "Vencer uma briga é a maior satisfação que existe", "Eu nunca fugiria diante de uma briga". Assim, embora a escala não tenha sido concebida para avaliar ou predizer condutas violentas, pode-se pensar 
que há um subconjunto específico de itens que pode ter contribuído para detectar uma diferença entre os grupos GV e GNV, com GV apresentando escores médios mais altos, indicativos de mais problemas.

A escala de Imaturidade ( $\mathrm{Im}$ ) diferenciou os grupos no T2, embora não fosse esperado essa diferença em nenhum dos tempos, em razão do fato de o seu conteúdo não ter relação direta com a delinquência violenta, como se pode observar pelo conteúdo dos itens: "Quando me criticam eu me sinto facilmente ferido", "É difícil se divertir a não ser que eu esteja com meus amigos" e "Só um bebê é que chora quando se machuca". Essa escala reflete a extensão com a qual o indivíduo falha em demonstrar respostas, atitudes e percepções esperadas para alguém de sua idade (Jesness, 2003). Pontuar baixo em Im indica uma orientação realista maior, embora escores muito baixos podem sugerir pessimismo e cinismo acentuados (Bazon, 2016). Adolescentes infratores tendem a pontuar mais alto nessa escala (Jesness, 2003), como foi constatado em contexto brasileiro, no qual adolescentes infratores/judicializados tiveram maior pontuação que os não-infratores/não-judicializados (Costa, Komatsu \& Bazon, 2017). No presente estudo, os grupos não se diferenciaram no T1, mas no T2 o GV apresentou escores médios mais elevados. Contudo, apesar da diferença encontrada entre os grupos, cabe ressaltar que ambos estariam dentro da faixa normativa, nos tempos $\mathrm{T} 1$ e T2, o que reforça a tese de que a escala de Im não possui relevância para explicar o engajamento em condutas violentas. Segundo Cowden, Peterson e Pacht (1969) e Jesness (2003), adolescentes infratores que pontuam mais alto nessa escala são menos aderentes aos programas de tratamento e, por isso, apresentam piores prognósticos.

A escala Autismo (Au), por sua vez, remete à tendência do indivíduo ter seu pensamento regulado excessivamente por necessidades pessoais, de modo que a percepção de si e do outro, assim como o planejamento da ação, se apresentam como fortemente autocentradas e, por conseguinte, irrealistas (Jesness, 2003), como se pode observar pelos itens: "Eu me sinto mal quando sou repreendido, acusado ou criticado", "Muitas pessoas falam de mim por trás" e "É preciso ser alguém muito inteligente para me enganar". Nesse sentido, indivíduos que pontuam alto costumam atribuir uma importância exagerada às próprias necessidades, formando uma imagem amplificada de si próprio, juntamente com a experimentação de uma dificuldade para diferenciar o que é seu (em termos de subjetividade) do que não é (Bazon, 2016). Os estudos de validade do IJ-R apontam que indivíduos que pontuam alto nessa escala tendem a apresentar comportamentos hostis e agressivos (Jesness, 2003). Assim, era esperado que o GV apresentasse uma média superior ao GNV, o que se confirmou com os resultados obtidos. No entanto, observa-se que, apesar das diferenças entre 
os grupos, ambos pontuaram, em média, dentro da faixa normativa. Esse resultado pode dever-se ao tamanho limitado da amostra, tanto no T1 quanto no T2, bem como ao fato de os componentes abarcados pela escala remeterem a aspectos que atuam mais como condições de vulnerabilidade, que de risco propriamente.

A escala de Alienação (Al) refere-se à desconfiança e ao estranhamento em relação ao outro, de modo que indivíduos que pontuam alto nessa escala costumam ser céticos e críticos em relação às pessoas, especialmente em relação às figuras de autoridade, repercutindo em uma atitude predominantemente hostil em suas respostas (Jesness, 2003), observado pelos seguintes itens: "A maior parte dos policiais está pronta para ajudar você" (pontua quando falso), "Os policiais metem o nariz em muitas coisas que não é serviço deles", "A maioria das pessoas que mandam é arrogante". Geralmente, a escala Al distingue adolescentes infratores de não infratores (Costa, Komatsu \& Bazon, 2017; Jesness, 2003), e os resultados aqui obtidos não indicaram diferenças significativas no T1, mas a escala foi capaz de diferenciar adolescentes infratores violentos de não violentos no final da adolescência/início da vida adulta, indicando que adolescentes que permanecem na trajetória de condutas violentas podem apresentar piora nessa escala ao longo do tempo, mas que a escala de Alienação, por si, não consiste em um fator de risco para a violência.

A escala Agressividade Manifesta (AM), conforme o esperado, discriminou os grupos nos dois tempos. Essa escala consiste primariamente em itens de natureza afetiva que sugerem a presença de sentimentos de raiva e de hostilidade facilmente eliciados (Jesness, 2003), como indicam o conteúdo de seus itens: “Às vezes eu tenho a impressão de que eu quero bater em alguém", "É difícil para qualquer pessoa saber em que momento ela vai sentir raiva ou se meter em encrenca" e "Um tipo como eu, primeiro entra na briga e depois faz as perguntas". Altas pontuações em AM estão associadas a comportamentos hostis e agressivos, fazendo com que indivíduos que apresentam essas características tendam a ser mais reativos e a cometerem delitos violentos (Jesness, 2003; Bazon, 2016), o que explicaria o motivo do GV ter pontuado bem acima de GNV. Cabe ressaltar que o GNV obteve pontuação média equivalente à população normativa, indicando que essa escala seja específica para a questão da violência, sem contudo diferenciar infratores gerais de não infratores.

A escala Retraimento/Depressão (Rt/Dep) não diferenciou os grupos em T1, mas passou a diferenciar em T2, com GV pontuando me média mais alto que GNV. Esta escala avalia o quanto o indivíduo tende a resolver seus problemas de falta de satisfação consigo mesmo e com os outros por meio de uma fuga passiva ou do isolamento (Jesness, 2003), como indicam seus itens: "Eu me sinto muitas vezes sozinho e triste", "Na minha vida nunca 
aconteceu uma grande coisa" e "Eu gosto mais de ficar sozinho do que com as outras pessoas". Pessoas com alta pontuação costumam se perceber como deprimidas, incompreendidas, insatisfeitas consigo mesmo e com os outros, preferindo ficar sozinhas mesmo que acompanhadas por um sentimento de solidão (Jesness, 2003). Embora os itens de Rt/Dep remetam a conteúdos que não se liguem diretamente à delinquência em geral e tampouco à violência em específico, eles remetam a aspectos de emotividade negativa e isolamento social - que tem se mostrado associado à violência, inclusive predizendo-a (Dam et al., 2018; Lahey \& Waldman, 2005). O fato dos grupos terem se diferenciado apenas em T2 sugere que a Rt/Dep não atua diretamente para a manifestação da conduta violenta, mas que os indivíduos que permanecem em uma trajetória marcada por atos violentos acabam por experimentar mais sentimentos negativos ligados à depressão e ao isolamento.

Na mesma direção, Ansiedade Social (AS), que remete a sentimentos de ansiedade e desconforto emocional nas interações sociais/nas relações interpessoais, mostrou diferença entre os grupos, novamente, somente quando mais velhos (T2), o que pode indicar que os sentimentos/emoções negativas atreladas tanto à Rt/Dep quanto à AS mantem-se estável e dentro da normalidade naqueles que não se engajam em violência e se acentuem naqueles que se engajam em violência na passagem da adolescência para a adultez. A exemplo do que se escreveu a respeito da escala Rt/Dep, os aspectos subjetivos avaliados por essas duas escalas também remetem àquilo que descreve o construto maior, a Emotividade Negativa, que expressa a tendência em experienciar estados negativos como tristeza, raiva, ansiedade e estresse, como indicam os itens: "Eu fico nervoso se ficar muito tempo parado sentado", "Eu me preocupo pelo que as outras pessoas pensam de mim" e "Eu sinto que meu coração bate mais rápido quando alguém não para de me fazer perguntas". Estudos indicam forte relação entre esses traços disposicionais e condutas violentas (Capaldi, Knoble, Shortt, \& Kim, 2012; Moffitt, Krueger, Caspi \& Fagan, 2000). Assim, tem-se que GV novamente pontuou mais alto que o GNV no T2. Jesness (2003) aponta que não há diferenças importantes entre infratores e não-infratores nesses atributos. Costa, Komatsu e Bazon (2017), todavia, verificaram que adolescentes infratores/judicializados pontuaram mais alto que adolescentes nãoinfratores/não-judicializados, a partir da segunda metade da adolescência. Sendo esta escala composta por itens relacionados principalmente a situações ansiogênicas na interação com o outro, pode-se supor que essa ansiedade é causada por déficits de repertório social, que por sua vez está relacionado a uma probabilidade maior de se recorrer a métodos/estratégias para atender necessidades ou para solucionar problemas pessoais que não são socialmente aceitáveis, o que pode incluir o uso da violência (OMS, 2009). 
A escala Negação (Neg) também foi capaz de distinguir os grupos apenas no T2. Essa é a única escala invertida do Instrumento, na qual se espera pontuações mais baixas em infratores (em comparação a não-infratores). Os itens da escala, por exemplo "Meu pai era muito ocupado para cuidar de mim, se preocupar comigo" e "Eu acho difícil conversar sobre meus problemas com minha família e com meus pais", remetem a uma condição na qual o indivíduo vive e apreende problemas/conflitos familiares e inadequações/dificuldades pessoais, mas tenta não pensar nisso, de modo a não se sentir invadido e imobilizado pelos sentimentos de infelicidade que estas questões podem suscitar. Uma pontuação relativamente elevada nessa escala é indicativa de maior ajustamento emocional, denotando um certo otimismo (Jesness, 2003) e a existência de recursos pessoais adequados para evitar sentimentos ruins (Santos, Komatsu \& Bazon, 2019). No transcorrer da adolescência, conforme vão adquirindo mais capacidade de perceber os problemas dentro da própria família, adolescentes infratores tendem a pontuar em Neg mais baixo que adolescentes não infratores (Costa, Komatsu \& Bazon, 2017). Os resultados obtidos indicaram que GNV pontuou mais alto que GV, o que parece fazer sentido. Contudo, apesar da diferença significativa, os dois grupos apresentaram pontuações médias dentro da faixa normativa, quando na verdade, esperava-se que os dois grupos pontuassem abaixo da média normativa, o que ocorreu ligeiramente com o GV. De igual modo ao pontuado para $\mathrm{Au}$, esse resultado pode dever-se ao tamanho limitado da amostra, bem como ao fato de os componentes abarcados pela escala remeterem a aspectos que atuam mais como condições de vulnerabilidade, que de risco propriamente.

As últimas duas escalas que diferenciaram os grupos tanto em T1 quanto em T2 são Transtorno de Conduta (TC) e Transtorno Opositivo Desafiador (TOD), ambas com itens que remetem aos critérios para diagnóstico dos transtornos homônimos, descritos no DSM-IV (Jesness, 2003). O resultado obtido em TC, com GV pontuando mais alto era esperado, uma vez que seus itens remetem diretamente a condutas violentas como, por exemplo: "Eu já fui mal com pessoas ou animais" e "Eu já usei uma arma que poderia ter machucado alguém". Dessa forma, o resultado reforça a validade concorrente do instrumento, embora não contribua explicitamente para explicar o porquê dos comportamentos violentos. A escala TOD, por sua vez, compreende itens que remetem a condutas de enfrentamento, e também a conteúdos atitudinais relacionados a situações de desobediência a figuras de autoridade: "Quando alguém me manda fazer alguma coisa, eu tenho vontade de fazer o contrário" e "Sinto muito prazer em irritar algumas pessoas". Sendo os delitos violentos uma modalidade dentro de uma grande classe de comportamentos que ferem normas e desafiam as autoridades 
(que são responsáveis por regular/controlar esse tipo de conduta), pode-se supor a existência de uma correlação positiva entre os escores nessa escala e as medidas de atos de desobediência tanto mais forte, mais evidente, quanto mais explicitamente tais comportamentos forem, o que é o caso daqueles que implicam em violência interpessoal, o que, talvez, explique o fato do GV ter uma pontuação maior que GNV também nessa escala. Ademais, destaca-se que TOD é, por alguns autores, considerado um traço multidimensional, incluindo Irritabilidade. Nesse sentido, o estudo de Aebi e colegas (2015) encontrou que esta dimensão específica de TOD se mostra fortemente associada à reincidência de delitos violentos.

O Índice de Associabilidade (IA), composto por uma combinação de itens das outras escalas com a função de distinguir adolescentes infratores (engajamento infracional) e não infratores (não engajamento infracional) com maior acurácia, em razão de sua orientação social antissocial (Jesness, 2003) discriminou GNV e GV somente no T1, com GV pontuando mais alto que GNV, o que se alinha à própria diferença nos padrões de conduta encontrada. Todavia, como o IA sintetiza informações que indicam uma tendência para comportar-se de um modo a transgredir regras sociais estabelecidas, essa escala é teoricamente mais útil na avaliação do potencial de risco de reincidência infracional geral (Bazon, 2016). Assim, como os dois grupos aqui comparados são compostos por adolescentes infratores que apresentam uma delinquência persistente, não era esperado que se distinguissem quanto à pontuação no IA, o que se verificou somente em T2. Ressalta-se, de todo modo, que os dois grupos estiveram acima da média da população normativa nos dois tempos.

Por fim, a única escala em que os dois grupos não se diferenciaram em T1 e em T2 foi Repressão (Rep). Os itens da escala de Repressão buscam apreender um modo de funcionamento psicológico em que o indivíduo tende a "retirar da consciência" as sensações e os sentimentos desagradáveis, inerentes à vida, assim como raiva e o desgosto atrelados, de modo a forjar uma imagem para si e para o outro de hipernormalidade, como se tudo estivesse sempre bem raiva e desgosto (Jesness, 2003; Bazon, 2016). No geral, adolescentes infratores pontuam mais alto que adolescentes não infratores nessa escala (Costa, Komatsu \& Bazon, 2017; Jesness, 2003). Pelos resultados obtidos, nos dois momentos, os adolescentes dos dois grupos lançariam mão deste mecanismo de defesa de igual modo, sendo que não se esperava que diferenciassem aqueles que se engajam em delitos violentos dos que não se engajam.

De forma geral, os resultados obtidos com a aplicação do Jesness, nos dois momentos, indicam que os infratores apresentando uma conduta delituosa violenta apresentariam 
funcionamento psicológico mais prejudicado. A gravidade dos atos infracionais consiste em um importante indicador de engajamento infracional que se faz acompanhar por algum nível de disfuncionalidade (aferida por uma performance "pior" nos aspectos avaliados). Em contrapartida, observou-se que a pontuação do GNV esteve, em média, não apenas dentro da normalidade como muito próximo à da população normativa em todas as escalas do IJ-R-Br, nos tempos 1 e 2. A única exceção foi o Índice de Associabilidade, que esteve aproximadamente um desvio-padrão acima da população normativa, também nos dois tempos. Esse dado indica que, em termos de funcionamento psicológico, esses adolescentes apresentariam um funcionamento muito semelhante ao de adolescentes de suas idades, o que sugere que as necessidades criminogênicas desses jovens são de natureza mais contextual e social do que pessoal.

Partindo para a discussão dos resultados concernentes às trajetórias, relativa às alterações na manifestação da conduta delitiva com observação em dois tempos, sublinha-se primeiramente o fato de os indivíduos, ainda que uma minoria, apresentarem mudanças substanciais em vários domínios em um período relativamente curto, evidenciando a plasticidade do comportamento humano e, com isso, a possibilidade de intervenção visando mudanças nas trajetórias condutuais, a curto e a médio prazo, mesmo em meio a indivíduos apresentando significativo engajamento infracional. Observando os adolescentes que no T1 eram violentos e no T2 deixaram de ser (V-NV), observou-se que as alterações mais substanciais se processaram no plano das variáveis psicológicas, tomando por base os constructos avaliados pelo IJ-R-Br, uma vez que passaram a exibir escores na faixa da normalidade. Destaca-se, nesse plano, os escores médios em Desadaptação Social (DS), que diminuíram significativamente do $\mathrm{T} 1(\mathrm{M}=61,8 ; \mathrm{Mdn}=64)$ para o $\mathrm{T} 2(\mathrm{M}=54,9 ; \mathrm{Mdn}=54)$. A escala DS é um indicativo das dificuldades do indivíduo em respeitar as exigências da vida social, representadas por inquietações e dificuldades em controlar os impulsos e os sentimentos hostis. Dessa forma, essa escala representa um importante aspecto do funcionamento do indivíduo e parece associado ao comportamento violento. No âmbito das variáveis sociais, do T1 ao T2, também se verificou diminuição significativa, nos adolescentes do grupo V-NV, em frequentação de Pares Infratores, o que também ajuda a entender a redução observada na escala de Problemas com a Polícia e a Justiça, igualmente significativa.

Em relação aos adolescentes cuja conduta percorre trajetória oposta, indo da não violência para a violência ( $\mathrm{NV}-\mathrm{V})$, observa-se, em um primeiro plano, que passaram a apresentar uma diversidade de atos significativamente maior, o que era esperado, dado que antes eles não haviam revelado delitos violentos e passaram a revelar, embora não se note 
aumento significativo na frequência dos delitos. Ou seja, seu padrão condutual não se agrava em termos de frequência, mas em termos de violência, ao passarem à prática de delitos requerendo uso de abordagem violenta na sua consecução. Por se tratar de um grupo muito diminuto de adolescentes - apenas sete indivíduos - as constatações a respeito desse grupo são muito particulares, e se prestam o oferecer pistas sobre os aspectos relevantes associados às alterações na trajetória, sem que se possa efetivamente generalizar os achados para o segmento. Isto posto, ressalta-se que sua conduta se fez acompanhar por aumento substancial nos escores associados a valores antissociais e a atitudes violentas, do T1 ao T2, assim como em escores do IJ-R-Br, no qual se nota maior desvio em relação à população normativa e uma piora, no sentido da interpretação do instrumento, em relação a como se apresentavam em T1, especificamente nas escalas DS e AM. Ou seja, nesses adolescentes os sentimentos de raiva, as atitudes de hostilidade e os níveis de impulsividade aumentam e, consequentemente, as dificuldades em respeitar as exigências da vida social.

Nas análises de regressão se destacou o fato de que o histórico não oficial de delitos violentos é o principal fator preditivo de delitos violentos no futuro, reiterando a máxima de que o modo como a pessoa se comporta, mediante inalteração das circunstâncias, tende a se manter estável. A escala Desadaptação Social do IJ-R-Br também esteve presente nos dois modelos, alinhando-se ao que se verificou nas comparações dos adolescentes de um tempo a outro. A escala Pares Infratores foi a terceira variável destacada, também presente nos dois modelos. As escalas Ansiedade Social e Negação do IJ-R-Br completaram o modelo 1 e as escala Transtorno de Conduta do IJ-R-Br e Atraso Escolar do QCJ completaram o modelo 2. Nos testes preditivos, os dois modelos apresentaram alta acurácia (74\% e 83\%, respectivamente). A capacidade em classificar corretamente os infratores apresentando conduta não violenta (especificidade) foi de $77 \%$ nos dois modelos; e a capacidade em classificar corretamente os infratores apresentando conduta violenta (sensibilidade) foi de $70 \%$ no modelo 1 e $90 \%$ no modelo 2 . Tais índices são considerados altíssimos para ciências do comportamento humano, mostrando que os construtos que compuseram os modelos são medidas representativas da problemática em foco, representando diferentes e variados aspectos da funcionalidade do indivíduo, conseguindo abarcar em si fatores importantes para a predição do comportamento violento. Assim, no plano ambiental, para os adolescentes investigados, destacam-se as variáveis pares infratores e atraso escolar.

Com relação ao fato de os fatores protetores não aparecerem no modelo, há duas observações a serem feitas. A primeira refere-se ao fato desses fatores serem pouco explorados nos instrumentos. No QCJ, apenas 8 escalas (de 23) referem-se a fatores de 
proteção, sendo algumas dessas medidas claramente frágeis, como descrito na descrição do instrumento. Nesse sentido, tanto na atividade de investigação quanto na de avaliação e de intervenção, se faz necessário incorporar ferramentas que alcancem os fatores protetores dos indivíduos. A segunda refere-se ao fato de que os aspectos de personalidade, em tese, se mostrarem como reflexo da influência dos fatores protetivos, de igual modo aos fatores de risco. Considerando que a personalidade resulta da interação entre traços - características pessoais - e estímulos ambientais / experiências de vida, pode-se considerar que aspectos da personalidade, passíveis de avaliação, consistem em uma medida que sintetiza a influência resultante da exposição do indivíduo aos fatores de risco e de proteção, ainda que a avaliação não deixe claro quais fatores/vivências são essas.

Nesse sentido, ressalta-se os aspectos dinâmicos da interação entre esses fatores, como os efeitos que a frequentação de pares infratores pode produzir na constituição do sistema de crenças e de valores desses adolescentes, mediante dificuldades escolares que concorrem para um gradual afastamento dos jovens dessa instituição (atraso escolar). Ou da influência do temperamento impulsivo na busca por atividades de risco que podem facilitar a construção de uma rede de pares que buscam o mesmo tipo de atividade. Ou a própria conduta violenta, que pode ter como consequência a apreensão e a internação, produzindo vivências específicas em instituições da Justiça Juvenil. Ou, ainda, a não apreensão e uma possível naturalização da conduta violenta em função do reforço positivo que ela pode produzir. Assim, mais do que a contribuição de cada um dos fatores isoladamente, deve-se considerar a interação entre eles e o efeito cumulativo decorrente dessa interação.

Finalizando, ressalta-se a necessidade de testar a eficácia do modelo em outras populações. Deve-se considerar também a adição de julgamentos profissionais estruturados que possam melhorar a eficácia do modelo. Investigações futuras podem/devem ser empreendidas focalizando as mudanças individuais, mais do que a pontuação média dos grupos, o que poderá acrescentar informações mais precisas e oferecer uma compreensão maior dos mecanismos que promovem as alterações nas trajetórias condutuais. Esse enfoque pode ser feito por meio de análises de cluster centradas na pessoa como, por exemplo, a de classes latentes. 


\subsection{Limitações e contribuições do estudo}

Os resultados aqui apresentados devem ser interpretados considerando o número relativamente pequeno da amostra e a perda de participantes ao longo do tempo, o que circunscreve os resultados, e limitam sua generalização. Conforme aponta a literatura (Nagin, 2005), a análise de trajetórias requer que o estudo seja iniciado com um número amostral grande para compensar as perdas e a reduzida porcentagem de adolescentes para os quais se observa mudanças de trajetória num período curto, dado constatado por esse estudo. A quantidade reduzida de participantes para os quais se denotou mudança nas trajetórias da conduta (NV-V e V-NV) dificultou a abordagem quantitativa pretendida. Em relação ao aspecto instrumental, destaca-se o fato de o QCJ compreender um rol diminuto de delitos violentos, ignorando comportamentos relevantes para o estudo do objeto em foco, como ameaças, bullying, agressões sexuais e homicídios. Há também fragilidades em várias de suas escalas psicossociais, cujos índices de precisão e de validade são baixos nas escalas Investimento Familiar, Supervisão Parental, Atividades Pró-Sociais, Bairro Deteriorado e Desempenho Acadêmico (Komatsu, Costa, Salgado \& Bazon, 2019).

Ainda com vistas ao estudo das trajetórias, outra importante limitação a ser considerada deve-se ao fato (não intencional) de os adolescentes recrutados para o estudo, já no T1, apresentarem uma delinquência persistente e, alguns, uma delinquência persistente envolvendo violência, uma vez que tinham em média três delitos oficiais em suas trajetórias, alguns deles classificáveis como violentos, o que suscita a questão de os padrões condutuais à época já estarem em alguma medida estabelecidos, verificando-se que somente uma minoria dos indivíduos apresentou alteração do padrão de conduta do T1 ao T2, seja no sentido de tornar-se violento ou de deixar de ser violento. Esse desenho, contudo, permitiu uma análise adicional, transversal (além da longitudinal), baseada no modelo "caso-controle", de forma que nos dois tempos pode-se investigar quais variáveis psicossociais mostravam-se associadas à delinquência persistente maior, ou seja, àquela em que há agravamento no sentido de envolver delitos violentos.

De todo modo, pode-se considerar que o modelo preditivo se beneficiou em parte do fato de adolescentes estudados apresentarem desde o T1 uma delinquência persistente, uma vez que se se considerasse apenas a informação de delito oficial prévio o modelo teria acertado a maioria dos resultados. Cabe, contudo, ressaltar que o modelo se saiu melhor do que se apostasse apenas nessa informação (delito prévio) e logrou em predizer corretamente a 
classificação dos indivíduos que mudaram de trajetória, com base em outros indicadores que remetem ao funcionamento psicológico e à exposição aos riscos.

À parte tais considerações, destaca-se que os principais fatores identificados no estudo referem-se a aspectos do funcionamento psicológico, tais quais os aferidos pela escala Desadaptação Social (DS) do IJ-R-Br, e a aspectos sociorrelacionais como frequentação de pares infratores, fracasso acadêmico representado pelo atraso escolar e histórico de problemas de conduta (escala TC do IJ-R-Br), em especial o comportamento violento prévio (histórico de delitos não oficiais aferido pelo QCJ). Por se tratar de um primeiro passo para a elaboração de um protocolo estruturado de avaliação de risco de envolvimento em violência em adolescentes/jovens no contexto brasileiro, os resultados aqui apresentados são bastante promissores, no sentido de elucidar os mecanismos que operam para a produção do engajamento em condutas violentas e de apoiar tomadas de decisão melhores que as embasadas por instrumentos gerais não específicos. 
178 | Estudo empírico: o desenvolvimento do comportamento violento 


\section{CAPÍTULO 5}

\section{IMPLICAÇÕES DA TESE E CONSIDERAÇÕES FINAIS}

Os profissionais nos campos de atuação forense e saúde mental lidam, em suas práticas, cada vez mais com situações em que se demanda avaliação de risco para a violência. Nesse sentido, a presente tese contribuiu sistematizando o conhecimento disponível na literatura nacional e internacional e oferecendo informações novas provenientes do estudo empírico. Cabe, neste último capítulo, fazer apontamentos sobre o caminho, que se acredita, importante a trilhar no âmbito das políticas públicas, das práticas profissionais e das atividades de pesquisa.

\subsection{Políticas públicas de prevenção - apontamentos}

Lipsey, Howell, Kelly, Chapman e Carver (2010) propõem que as duas metas das políticas públicas na área devem ser proteger a sociedade e propiciar mudanças nas trajetórias de vida dos jovens violentos e, com isso, na trajetória da conduta violenta que risca se desenvolver. Diferentes autores sugerem que essa meta só pode ser alcançada se houver integração entre os diferentes serviços públicos e privados e listam um conjunto de componentes necessários a um sistema colaborativo entre os serviços, a serem contemplados para reduzir os riscos e aumentar a proteção (Baker-Henningham \& Bóo, 2010; Komatsu, Costa \& Bazon, 2018; Lipsey et al., 2010):

Uma primeira linha de políticas públicas deve visar promoção do desenvolvimento integral e prevenção de problemas de comportamento desde os primeiros anos de vida (Hughes \& Enzor, 2010; Komatsu, Costa e Bazon, 2018). Como explicado no capítulo dois, experiências prévias são levadas adiante no processo de desenvolvimento humano, impactando de forma positiva ou negativa as fases seguintes. Portanto, aquisições satisfatórias na infância facilitam aquisições na adolescência. De modo contrário, déficits e traumas na infância produzem dificuldades de adaptação psicossocial na adolescência, que podem ser levadas à vida adulta, mediante falta de ajuda / de apoio, produzindo uma série de prejuízos em diferentes áreas da vida. Nesse sentido, faz-se necessário capacitar as famílias a fornecerem monitoramento, apoio e estimulação adequados a seus filhos. Essa psicoeducação 
poderia ocorrer, inicialmente, de modo relativamente informal, em contexto de acompanhamento pós-parto ou nas oportunidades criadas pelas primeiras vacinações, por exemplo, tal qual se faz com relação a outros temas da área da saúde. Por exemplo, o estudo de Wendland-Carro, Piccinini e Millar (1999) mostrou que um grupo de mães que assistiram a um vídeo curto sobre a importância da interação entre mãe e bebê mostrou-se mais responsivos às necessidades do filho, um mês após o vídeo, comparado a um grupo de mães que assistiram outro vídeo não relacionado. Assim, mesmo intervenções simples/curtas podem produzir efeitos positivos e duradouros no comportamento dos pais.

É importante também que haja instituições sociais voltadas à oferta de apoio no cuidado/educação das crianças, como creches e brinquedotecas, a todo cuidador que precise e/ou queira. Sem embargo, é necessário que essas instituições contem com profissionais capacitados e com estrutura adequada para fomentar o desenvolvimento e a socialização das crianças. Os profissionais necessitam entender o seu papel e a importância da estimulação nessa etapa da vida. As atividades a oferecer devem, por exemplo, serem significativas em relação ao desenvolvimento das funções executivas. A revisão de Benson e Sabbagh (2017) mostra que a estimulação por meio da interação social nessa etapa é crucial para o desenvolvimento das funções executivas, em função da qual a criança desenvolve, entre outras habilidades, a capacidade de se colocar no lugar do outro, elemento importante para a proteção à agressividade reiterada e, com isso, às condutas violentas em etapas posteriores da vida. É preciso também que haja programas de capacitação aos profissionais em contexto escolar, para que possam identificar precocemente crianças em situação que ameaçam o seu desenvolvimento, experienciando maus-tratos, abusos e negligência, ou outras práticas parentais negativas, de modo possam intervir adequadamente junto à família ou acionar rapidamente serviços mais especializados.

Uma segunda linhagem de políticas públicas deve focalizar o apoio e a capacitação das famílias para fornecerem monitoramento, estimulação e suporte a seus filhos (Bernier, StLaurent, Matte-Gagné, Milot, Hammond \& Carpendale, 2017). O acompanhamento das famílias deve ser contínuo, visto que as diferentes fases desenvolvimentais da criança e do adolescente são muito particulares e requerem competências especificas para a oferta de cuidados específicos. Programas de capacitação podem ser fornecidos em âmbito comunitário ou escolar, facilitando também a troca de experiências com outros pais/cuidadores, sempre guiados e assessorados por profissional capacitado. Entre as habilidades importantes a serem desenvolvidas estão: monitoramento não coercitivo; educação consistente e coerente; apoio 
emocional e social; técnicas de autocontrole (para si mesmos e para ensinar aos filhos); reconhecimento das necessidades do filho e dos melhores momentos para intervir (por exemplo, programas de intervenção (Cano, 2015) mostram que é ineficaz tentar intervir quando o adolescentes está em estado de raiva - justamente o momento em que muitos pais creem ser necessário intervir).

Uma terceira linha consiste em identificar infratores persistentes e violentos e prover enquadramento institucional adequado, mediante falha de medidas em meio aberto (Lipsey et al., 2010; Seifert, 2012). Sabe-se que o fracasso em medidas judiciais/socioeducativas anteriores consiste em um forte preditor para a violência. Nesse sentido, o melhor a ser feito é identificar indivíduos nessa situação e alocá-los em instituições com programas bem elaborados, com capacidade de ofertar tratamentos específicos para a delinquência persistente e violenta e promover reinserção. No Brasil, esse procedimento ocorre por meio da aplicação de medida de internação. Essas instituições certamente contemplam, ao menos temporariamente, a primeira meta de Lipsey e colegas (proteger a sociedade); mas há dúvidas de que contemplem satisfatoriamente a segunda (promover mudanças na trajetória das condutas). Para que isso ocorra é necessário que desenvolvam e implementem programas específicos para a reabilitação de infratores violentos - que transcendam objetivos meramente ocupacionais e/ou visando sua empregabilidade - com vistas ao seu desenvolvimento psicológico, no plano da empatia, da moralidade, do autocontrole e da autorregulação, e outras capacitações específicas relacionadas às necessidades psicossociais dos adolescentes. Concomitantemente, é preciso que os pais/cuidadores desses jovens sejam capacitados para recebê-los no ambiente de origem, na transição do meio fechado para o meio aberto. Nesse sentido, é preciso ressaltar que da mesma forma que o comportamento violento surge em função de múltiplos determinantes, a intervenção também deve focar múltiplos domínios (indivíduo, família, escola).

A quarta linhagem de políticas públicas na área consiste em capacitar profissionais de diferentes instituições que lidam com adolescentes/jovens a identificar problemas relacionados à saúde mental e ao abuso de substâncias psicoativas. Estima-se que mais da metade dos infratores do Sistema de Justiça Juvenil possuam problemas de saúde mental ou de uso de substâncias (Bono, Komatsu \& Bazon, 2019; Justice Policy Institute, 2009). Familiares, educadores, profissionais da saúde e da assistência social devem estar aptos a identificar problemas dessa natureza e acionar os serviços especializados para essas problemáticas. Adicionalmente, é necessário serviços especializados para tratar os 
adolescentes/os jovens em conflito com a lei que possuem alguma dessas problemáticas, em comorbidade com a delinquência persistente. Partindo da premissa de que cada adolescente infrator deve receber uma medida, um tratamento personalizado, condizente com suas condições e necessidades específicas, no caso de adolescentes com transtornos mentais ou apresentando um uso problemático de substâncias, esse princípio deve ser levado ainda mais à risca, pois essas condições impõe um tratamento e um manejo específico (Morgan et al., 2012).

Em síntese, as políticas públicas devem focalizar a redução de fatores de risco e a promoção de fatores protetores (1) na infância e (2) na adolescência, (3) estabelecer condições específicas de tratamento para infratores crônicos e violentos e (4) considerar as condições específicas de saúde mental, disponibilizando a estrutura e os recursos adequados para tratar essa natureza de problema.

\subsection{Programas de prevenção - práticas profissionais}

Focalizando a delinquência violenta, a prevenção primária consiste em uma série de medidas visando impedir que os adolescentes se envolvam em atos violentos. A prevenção secundária consiste em medidas que visam reabilitar os adolescentes que já se envolveram em condutas violentas, visando que não reincidam. Há na literatura dezenas de programas de prevenção e de tratamento/reabilitação para a conduta violenta em jovens, mas aqui serão abordados os programas mais efetivos, seguindo os quatro critérios propostos pelo Office of the Surgeon General (2001) como requisitos científicos para avaliar a efetividade do programa:

- Estudo com delineamento rigoroso (experimental ou quasiexperimental);

- Redução significativa na conduta violenta;

- Replicação demonstrando os efeitos obtidos;

- Efeitos duradouros (deve se manter ao menos um ano após a intervenção). 
A Tabela 5.1 sintetiza os principais apontamentos sobre os programas de prevenção revisados pelo relatório do Office of the Surgeon General (2001) que se mostraram efetivos para reduzir a violência e outros fatores de riscos em geral.

\section{Tabela 5.1}

Programas que se mostraram efetivos para reduzir o comportamento violento

\section{Seattle Social Development Project (J. David Hawkins)}

O programa trabalha múltiplos domínios com o objetivo de aumentar o vínculo da criança/adolescente com a escola e a família e diminuir diversos riscos que atingem essa faixa etária. As atividades envolvem alunos, professores e pais em diferentes momentos da intervenção, e dura por toda a adolescência. Adolescentes que passam por esse programa apresentam menos problemas com substâncias, comportamentos de risco e envolvimento em delitos violentos.

\section{Prenatal and Infancy Home Visitation by Nurses (David Olds)}

As ações previstas nesse programa iniciam-se antes do nascimento, com profissionais da saúde visitando os futuros pais em um intervalo de uma semana a um mês durante os dois primeiros anos de vida do bebê. O programa visa (1) promover suporte social à família; (2) incentivar o desenvolvimento pessoal das mães, incluindo o sucesso nos estudos e o desenvolvimento de competências sociais e de auto eficácia; (3) garantir a saúde e o desenvolvimento geral da criança. Esse programa reduz a prevalência de maus-tratos e negligência nas crianças e o envolvimento posterior em atividades antissociais, entre elas a conduta violenta, diminuindo também a taxa de aprisionamentos.

Functional Family Therapy (James F. Alexander)

Voltado para crianças ou adolescentes que estão sob alto risco ou já apresentam condutas violentas, o programa prevê de 8 a 30 horas de trabalho com o jovem e a família, dependendo das necessidades. O programa inclui desenvolvimento do engajamento para diminuir as chances de desistência do programa (entrevista motivacional), mudanças nas crenças e outros comportamentos mal adaptativos, avaliação dos comportamentos interpessoais, mudança de comportamentos por meio de um treinamento com o jovem e com os pais e uma etapa de generalização dos comportamentos desenvolvidos.

\section{Multisystemic Therapy (Scott Henggeler)}

Voltado para famílias de adolescentes em conflito com a lei que apresentam comportamento 
violento, delinquência crônica ou abuso de substâncias, esse programa se divide em quatro tipos de intervenção: terapia familiar estratégica, terapia familiar estrutural, treinamento parental e terapia cognitiva-comportamental. O programa demora cerca de 60 horas divididas em 4 meses. Os adolescentes que participam do programa apresentam redução na frequência de delitos e de comportamentos agressivos e violentos.

\section{Multidimensional Treatment Foster Care (Patricia Chamberlain)}

Voltado para famílias de adolescentes com histórico de delitos violentos ou delinquência crônica, o programa propõe um tratamento que oferece supervisões intensas em casa, na escola e na comunidade. Também inclui treinamento dos pais para que possam melhorar na educação com os filhos. Possui duração de aproximadamente 12 meses. Os jovens que participam desse programa apresentam redução significativa de atos violentos.

\section{School Transitional Environmental Program (Robert Felner)}

Esse programa postula que eventos transicionais (como mudar de escola) produz experiências estressantes que colocam a criança em risco para desenvolver problemas de comportamento. Assim, o programa visa reduzir o efeito estressor e a desorganização dessas mudanças de ambiente ao longo da vida, melhorando o desenvolvimento de competências do adolescente e reduzindo as taxas de evasão escolar, problemas de abuso de substâncias e de conduta violenta.

\section{Montreal Longitudinal Study/Preventive Treatment Program (Richard Tremblay)}

Consiste em uma intervenção de 2 anos junto a crianças de 7-9 anos de famílias de baixa renda. O programa se divide em treinamento de habilidades sociais na escola (19 sessões) e treinamento parental (17 sessões). O treinamento dos pais envolve entender a criança, monitorar e reforçar adequadamente, disciplinar efetivamente e gerenciar crises familiares. $\mathrm{O}$ programa melhora o ajuste da criança (e posteriormente, do adolescente) à escola e reduz as taxas de evasão escolar, os problemas com uso de substâncias, o envolvimento em gangues e o número de detenções pela polícia.

\section{Syracuse Family Development Research Program (J. Ronald Lally)}

Voltado a famílias de baixa renda, envolve visitas familiares para treinamento parental e um treinamento individualizado durante 5 anos, envolvendo cuidados diários e treinamento da criança em habilidades cognitivas e sociais. Esse programa produz bons resultados acadêmicos e reduz o envolvimento em brigas graves e o contato com a polícia aos 19 anos.

Perry Preschool Program (David Weikart)

Voltado para crianças de 3 a 4 anos de famílias de baixa renda, o programa prevê o 
desenvolvimento físico, intelectual e social por meio de estimulação intensa dois anos antes de a criança entrar na escola. O programa também prevê visitas domiciliares semanais para atender às necessidades sociais da família, se desejarem. Crianças que participaram do programa apresentam, ao longo da vida, melhores resultados acadêmicos, melhor inserção no mercado de trabalho e menos detenções na vida adulta do que crianças que não participaram do programa.

\section{Striving Together to Achieve Rewarding Tomorrows (Adele Harrell)}

Voltado para crianças/adolescentes de 11 a 13 anos que vivem em bairros conturbados, as intervenções inerentes ao programa foca em oito componentes, cada um relacionado com algum risco específico para a violência. Indivíduos que participam desse programa apresentam menor uso de substâncias e menos envolvimento em delitos violentos um ano após o programa.

\section{Intensive Protective Supervision Project (Kathy Dudley)}

O programa propõe o tratamento de jovens em conflito com a lei abaixo de 16 anos fora do sistema de justiça, colocando-os sob supervisões intensivas em meio aberto. Os resultados desse tipo de intervenção mostram-se melhores que as medidas padrões oferecidas pelo sistema de justiça.

Fonte: adaptado de Office of the Surgeon General (2001)

\subsection{Pesquisas futuras - apontamentos}

Para além dos delineamentos de pesquisas que possam cobrir as lacunas do método empregado no presente estudo, em alguma medida já indicadas, é necessário pensar em programas de pesquisa mais amplos que possam contemplar as grandes questões com relação ao conhecimento científico da problemática em foco no contexto sociocultural brasileiro, para a elaboração de protocolos de avaliação válidos e confiáveis e para estabelecer programas de prevenção eficazes.

Em primeiro lugar, seria muito importante a organização de um observatório da delinquência juvenil por meio da implementação de levantamentos de dados periódicos junto aos adolescentes, de modo a observar tendências. Esses levantamentos poderiam se dar em escolas públicas e privadas de diferentes cidades do Brasil, de forma a conseguir informações sobre uma amostra representativa. Seria importante levantar as crenças, os valores e as 
condutas para estabelecer parâmetros comparativos e identificar possíveis novas tendências. Por exemplo, atualmente o cyberbullying pode ser considerado uma forma de conduta violenta, porém pouco sabemos sobre a magnitude do fenômeno, as características dos autores e das vítimas, entre outras informações. Previamente aos levantamentos, seria importante realizar grupos focais para com esses jovens, para contemplar nos levantamentos atitudes e condutas que podem ser importantes, na visão dos jovens, mas que os instrumentos atuais não abarcam. É possível, por exemplo, que haja uma série de condutas violentas que hoje ainda não são tipificadas em lei e que seriam relevantes para um protocolo de avaliação de risco.

Este tipo de monitoramento já ocorre em diversas localidades: Add Health study (EUA), Child Development Project (EUA), Project on Human Development in Chicago (EUA), Multisite Violence Prevention Project (EUA), National Youth Survey (EUA), Pittsburgh Youth Study (EUA), The Survey of Recruits' Behaviors (EUA), RADAR (Holanda), Korean Youth Panel Study (Coreia do Sul), Crime in the Modern City (Alemanha), The Cambridge Study in Delinquent Development (Inglaterra), Australian Temperament Project (Australia), Queensland Longitudinal Data (Austrália), Individual Development and Adaptation (Suécia), Dunedin Multidisciplinary Health and Development Study (Nova Zelândia), International Self-Report Delinquency Study (35 países). No Brasil, ao que se sabe, há dois projetos de pesquisa de grande porte que se aproximam desses levantamentos, a saber a Pesquisa Nacional sobre a Saúde do Escolar (Instituto Brasileiro de Geografia e Estaística [IBGE], 2016) e o estudo longitudinal Socialização Legal na cidade de São Paulo (Núcleo de Estudos da Violência [NEV], 2017), que buscam levantar valores e comportamentos de risco dos adolescentes, mas não focalizam nos comportamentos delitivos e seus fatores explanatórios mais proximais. Destaca-se, também, que o Brasil passou a fazer parte da atual terceira onda de levantamentos do International Self-Report Delinquency Study, um estudo comparativo envolvendo 35 países, o que pode ser um grande avanço no sentido de conhecer a realidade brasileira. Porém, até o momento não se sabe sobre as características da amostra e o alcance dos resultados.

Em segundo lugar, seria importante acompanhar uma amostra relativamente grande por longo período de tempo. Pesquisas com delineamento longitudinal são necessárias para conhecer processos e estabelecer relações causais entre as variáveis, testar a capacidade preditivas de instrumentos e identificar variáveis importantes que não estavam previstas no início do estudo. A construção de um protocolo de avaliação de risco de violência deve, necessariamente, passar por uma validação preditiva. Sabe-se que a implementação de 
pesquisas longitudinais não é fácil nem barato, por isso seria necessário o amparo de agências de fomento de pesquisas e outras instituições que apoiassem a execução desses projetos (seja criando facilidades na entrada e nas coletas de dados, nas instituições, seja apoiando tecnicamente e financeiramente a equipe de pesquisa).

Em terceiro lugar, seria preciso desenvolver e testar programas de prevenção primária e secundária específicos para o contexto brasileiro. O objetivo final da avaliação de risco de violência consiste em propor medidas que possam gerenciar o risco e promover fatores protetivos. Em outras palavras, não basta apontar para o que está deficitário, se faz necessário apresentar soluções que favoreçam o curso do desenvolvimento para uma alternativa mais saudável. Como se abordou no tópico anterior, há vários programas de prevenção específicos para adolescentes que têm sido aplicados em diversos países e que se mostraram eficazes no sentido de produzir mudanças significativas e duradouras. Assim, um importante avanço na prevenção da violência consistiria em verificar a aplicabilidade e a eficácia desses e de novos programas em crianças e adolescentes brasileiros.

\subsection{Considerações finais}

A presente tese abordou a violência criminal no Brasil, estimada com base nas informações disponíveis de diferentes fontes de dados. Dentro dessa modalidade de violência, destacou-se a condição da população jovem, em razão das características da etapa de vida, crítica para o desenvolvimento de padrões de comportamento, incluído aí o antissocial e o violento. As diferentes circunstâncias desenvolvimentais - hormonais, fisiológicas, afetivoemocionais, cognitivas, relacionais e sociais - fazem com que a infância e a adolescência sejam os períodos mais sensíveis para a aquisição de capacidades que devem preparar o jovem para os diferentes desafios impostos pela vida em sociedade. Quando essas aquisições não acontecem de modo satisfatório, nos períodos propícios, problemas em diferentes áreas da vida tendem a se manifestar e a se acumular. Os adolescentes infratores persistentes, aqueles que praticam atos delituosos de forma reiterada, representam um grupo de adolescentes que por diferentes motivos apresentam dificuldades significativas no processo de adaptação positiva às normas sociais e para desenvolverem um padrão de comportamento pró-social. Dentro desta perspectiva, destacou-se a importância das MVI para orientar o trabalho de avaliação e os programas de prevenção primária e secundária. 
$\mathrm{Na}$ sequência, buscou-se explanar sobre os fatores e os mecanismos atinentes ao desenvolvimento desses padrões de conduta, tendo como referência a abordagem da Psicopatologia Desenvolvimental, realizando depois revisões sistemáticas da literatura para identificar os principais fatores de risco e de proteção para a conduta violenta na adolescência. Metanálises foram implementadas para combinar o efeito de diferentes estudos e reunir as evidências mais sólidas sobre o tema. Por fim, relatou-se os resultados de um estudo empírico em que uma pequena amostra de adolescentes em conflito com a lei foi acompanhada por um período de 18 meses, com vistas a monitorar e a identificar os fatores associados à conduta violenta e aqueles mais especificamente atrelados à alteração nas trajetórias da conduta, buscando testar um modelo preditivo. Os resultados encontrados sugeriram que mudanças em variáveis pessoais e sociais são acompanhadas por mudanças condutuais, e que a conduta violenta pode ser antecipada com elevado grau de acurácia com base em informações prévias. Tal achado, embora decorrente de um estudo modesto, em termos de amostra, coaduna com apontamentos da literatura e, assim, sugere frentes de trabalho para as políticas públicas, e para os profissionais que executam as medidas socioeducativas, além dos pesquisadores na área. Espera-se que o conhecimento produzido nesta tese transponha as barreiras acadêmicas e inspire atividades práticas, de forma a converter-se em conhecimento aplicável. 


\section{REFERÊNCIAS}

ABEP. Associação Brasileira de Empresas de Pesquisa. (2014). Critérios de classificação econômica 2014.

Acero, J. L. S. (2016). Violencia filioparental: características psicosociales de adolescentes y progenitores en conflicto familiar severo (Tese de doutorado). Universidade Complutense de Madrid, Madrid, Espanha.

Achenbach, T. M. (1974). Developmental psychopathology. New York, NY: Ronald Press.

Aebi, M., Barra, S., Bessler, C., Steinhausen, H., Walitza, S., \& Plattner, B. (2015). Oppositional defiant disorder dimensions and subtypes among detained male adolescent offenders. Journal of Child Psychology and Psychiatry, 57(6), 729-736.

Agnew, R. (1992). Foundation for a general strain theory of crime and delinquency. Criminology, 30, 47-88.

Agnew, R. (2001). Building on the foundation of general strain theory: Specifying the types of strain most likely to lead to crime and delinquency. Journal of Research in Crime and Delinquency, 38, 319-361.

Agresti, A. (2012). Categorical data analysis (3ed). Hoboken, NJ: John Wiley \& Sons.

Akers, R. L., Krohn, M. D., Lanza-Kaduce, L., \& Radosevich, M. (1979). Social Learning and Deviant Behavior: A Specific Test of a General Theory. American Sociological Review, 44(4):636-655. doi:10.2307/2094592

Allport, G. W. (1937). Personality: A psychological interpretation. New York, NY: Holt.

Alper, M., \& Chappell, A. (2012). Untangling fear of crime: a multi-theoretical approach to examining the causes of crime-specific fear. Sociological Spectrum: Mid-South Sociological Association, 32(4), 346-363. doi:10.1080/02732173.2012.664048 
Andershed, A.-K., Gibson, C. L., \& Andershed, H. (2016). The role of cumulative risk and protection for violent offending. Journal of Criminal Justice, 45, 78-84. doi:10.1016/j.jcrimjus.2016.02.006

Andrés-Pueyo, A., Arbach-Lucioni, K., \& Redondo-Illescas, S. (2009). Riscanvi completo: definición de ítems. (Documento não publicado).

Andrés-Pueyo, A. , Arbach-Lucioni, K. and Redondo, S. (2018). The RisCanvi: A New Tool for Assessing Risk for Violence in Prison and Recidivism. In J. P. Singh, D. G. Kroner, J. S. Wormith, S. L. Desmarais \& Z. Hamilton, Handbook of Recidivism Risk/Needs Assessment Tools (eds). Hoboken, NJ: John Wiley \& Sons. doi:10.1002/9781119184256.ch13

Andrés-Pueyo, A., \& Redondo-Illescas, S. (2007). Predicción de la violencia: entre la peligrosidad y la valoración del riesgo de violencia. Papeles del Psicólogo, 28(3), 157 173.

Andrews, D. A., \& Bonta, J. (2010). The psychology of criminal conduct (5th ed.). Cincinnati, OH, US: Anderson Publishing Co.

APA. American Psychological Asossiation. (2015). APA Dictionary of Psychology (Second Edition). York, PA: Maple Press. doi:10.1037/14646-000

Arffa, S. (2007). The relationship of intelligence to executive function and non-executive function measures in a sample of average, above average, and gifted youth. Archives of Clinical Neuropsychology, 22(8), 969-978. doi:10.1016/j.acn.2007.08.001

Associação Nacional dos Centros de Defesa da Criança e do Adolescente. (2007). Justiça Juvenil. A visão da ANCED sobre seus conceitos e prática, em uma perspectiva dos Direitos Humanos. São Paulo: ANCED.

Atwool, N. (2007). The role of secure attachment as a protective factor for vulnerable infants. Social Work Now, 38, 11-20. 
Bandura, A. (1977). Social learning theory. Englewood Cliffs, NJ: Prentice Hall.

Baker-Henningham, H., \& Bóo, F. L. (2010). Early Childhood Stimulation Interventions in Developing Countries: A Comprehensive Literature Review. IZA Discussion Paper No. 5282.

Barberet, R., Bowling, B., Junger-Tas, J., Rechea_Arberola, C., \& Zurawan, A. (2004). SelfReported Juvenile Delinquency in England and Wales, The Netherlands and Spain. Helsinki: HEUNI.

Barlett, C. P., \& Anderson, C. A. (2012). Direct and indirect relations between the Big 5 personality traits and aggressive and violent behavior. Personality and Individual Differences, 52:870-875.

Bazon, M. R. (2016). Avaliação Psicológica de Adolescentes em Conflito com a Lei: validação do Inventário de Jesness - Revisado. Tese de Livre Docência, Faculdade de Filosofia, Ciências e Letras de Ribeirão Preto, Universidade de São Paulo, Ribeirão Preto. Bazon, M. R., Costa, R., \& Komatsu, A. V. (2018). Validez de Constructo del Inventario de Jesness-Revisado-Brasileiro. In E. Arias, J. Sanmarco \& X. Camplá (eds.), XI Congreso Internacional de Psicología Jurídica y Forense: Libro de Actas (pp. 573). Santiago de Compostela, España: Sociedad Española de Psicología Jurídica y Forense.

Bazon, M. R., Komatsu, A. V., Panosso, I. R., Estevão, R. (2011). Adolescentes em conflito com a lei, padrões de comportamento infracional e trajetória da conduta delituosa: um modelo explicativo na perspectiva desenvolvimental. Rev. Bras. Adolescência e Conflitualidade, n. 5, p. 59-87.

Beckett, K. (1999). Making Crime Pay: Law and Order in Contemporary American Politics. Oxford University Press. 
Benjamini, Y., \& Hochberg, Y. (1995). Controlling the false discovery rate: a practical and powerful approach to multiple testing. Journal of the Royal Statistical Society B 57: 289300.

Benson, J. E., \& Sabbagh, M. A. (2017). Executive Functioning Helps Children Think About and Learn About Others' Mental States. Executive Functions in Childrens Everyday Lives, 54-69. doi:10.1093/acprof:oso/9780199980864.003.0005

Bernburg, J.G., Krohn, M.D., \& Rivera, C.J. (2006). Official Labeling, Criminal Embeddedness, and Subsequent Delinquency: A Longitudinal Test of Lebeling Theory. Journal of Research in Crime and Delinquency, 43; 67. doi:10.1177/0022427805280068

Bernier, A., St-Laurent, D., Matte-Gagné, C., Milot, T., Hammond, S. I., \& Carpendale, J. I. (2017). Parenting and Young Children's Executive Function Development. Executive $\begin{array}{lllll}\text { Functions } & \text { in } \quad \text { Childrens }\end{array}$ doi:10.1093/acprof:oso/9780199980864.003.0006

Bertini, I. M., \& Estevão, R. (1986). Inventário de Personalidade de Jesness: verificação da fidedignidade. Relatório de pesquisa enviado à FAPESP.

Best, J. (1999). Random Violence: How We Talk about New Crimes and New Victims. University of California Press.

Bono, E. L., Komatsu, A. V., Bazon, M. R. (2019). Padrões de uso de drogas e problemas associados em adolescentes em conflito com a lei. (Artigo em avaliação pelo periódico: Psico-USF).

Bonta, J., Law, M., \& Hanson, K. (1998). The prediction of criminal and violent recidivism among mentally disordered offenders: A meta-analysis. Psychological Bulletin, 123(2), 123-142. doi:10.1037/0033-2909.123.2.123

Borum, R. (2000). Assessing Violence Risk among Youth. Journal of Clinical Psychology, 56, 1263-1288. doi:10.1002/1097-4679(200010)56:10<1263::AID-JCLP3>3.0.CO;2-D 
Borum, R., Bartel, P., \& Forth, A. (2006). Manual for the Structured Assessment for Violence Risk in Youth (SAVRY). Odessa, FL: Psychological Assessment Resources.

Braga, T., Gonçalves, L. C., Basto-Pereira, M., \& Maia, Â. (2017). Unraveling the link between maltreatment and juvenile antisocial behavior: A meta-analysis of prospective longitudinal studies. Aggression and Violent Behavior, 33, 37-50.

doi:10.1016/j.avb.2017.01.006

BRASIL. Ministério da Justiça e Cidadania. Secretaria Nacional de Segurança Pública. (2013). Pesquisa Nacional de Vitimização. Brasília, DF: Senasp/MJC.

BRASIL. Secretaria Presidencial de Assuntos Estratégicos. (2018). Custos econômicos da criminalidade no Brasil. Relatório de Conjuntura nº 4. Brasília, DF.

Britto, V. M. V., \& Lomonaco, J. B. F. (1983). Expectativa do professor: implicações psicológicas e sociais. Psicologia: Ciência e Profissão, 3(2), 59-79. doi:10.1590/S141498931983000100005

Bugg, J. M., Zook, N. A., DeLosh, E. L., Davalos, D. B., \& Davis, H. P. (2006). Age differences in fluid intelligence: Contributions of general slowing and frontal decline. Brain and Cognition, 62, 9-16. doi:10.1016/j.bandc.2006.02.006

Burgess, R. L., \& Akers, R. L. (1966). A Differential Association-Reinforcement Theory of Criminal Behavior. Social Problems, 14(2):128-147. doi:10.2307/798612

Buss, A. H., \& Plomin, R. (2015). Temperament: early developing personality traits. New York, NY: Psychology Press.

BVS. Biblioteca Virtual da Saúde. (n.d.). Busca por informação e evidências científicas na Biblioteca Virtual em Saúde.

Campbell, T. W. (2003). Sex offenders and actuarial risk assessment: Ethical considerations. Behavioral Sciences and the Law, 21, 269-279. doi:10.1002/bs1.530 
Cano, A. (2015). Adolescentes y violencias: programas y experiencias efectivas. In J. Pérez \& M. Escrivá (coord.), El marco global de atención al menor: prácticas basadas en la evidencia, reflexiones y experiencias de éxito. Tirant lo Blanch.

Capaldi, D. M., Knoble, N. B., Shortt, J. W., \& Kim, H. K. (2012). A Systematic Review of Risk Factors for Intimate Partner Violence. Partner Abuse, 3(2), 231-280.

Capdevila, M. C., Serentill, M. B., Ferrer Puig, M., Andrés-Pueyo, A., Ferrer, B. F, López, N. C. ... Encinas, J. M. (2015). Tasa de reincidencia penitenciaria 2014. Centro de Estudios Jurídicos y Formación Especializada, Generalitat de Catalunya.

Caprirolo, D., Jaitman, L., \& Melo, M. (2017). Os custos de bem-estar do crime no Brasil: um país de contrastes. In L. Jaitman (ed.), Os custos do crime e da violência: Novas evidências e constatações na América Latina e Caribe. Nova Iorque, NW: Banco Interamericano de Desenvolvimento. doi:10.18235/0000615

Casey, P. M., Warren, R. K., \& Elek, J. K. (2011). Using offender risk and needs assessment information at sentencing: Guidance for courts from a national working group. Williamsburg, VA: National Center for State Courts.

Castro, J., Cardoso, C., \& Agra, C. (2010). Projecto: Observatório da Delinquência Juvenil. Relatório Final. Escola de Criminologia, Faculdade de Direito da Universidade do Porto. (Não publicado).

Catalano, R. F., \& Hawkins, J.D. (1996). The social development model: a theory of antisocial behavior. In J. D. Hawkins (ed.), Delinquency and Crime: Current Theories (pp. 149-197). Cambridge: Cambridge University Press.

Caton, C., Samet, S., \& Hasin, D. (2000). When Acute-Stage Psychosis and Substance Use Co-Occur: Differentiating Substance-Induced and Primary Psychotic Disorders. Journal of Psychiatric Practice, 6(5):256-66. 
Center on the Developing Child (2012). Executive Function (InBrief). Disponível em: http://developingchild.harvard.edu/resources/inbrief-executive-function/ Acessado em: Abril de 2017.

Chen, P., Voisin, D. R., \& Jacobson, K. C. (2013). Community Violence Exposure and Adolescent Delinquency: Examining a Spectrum of Promotive Factors. Youth \& Society, 48(1), 33-57. doi:10.1177/0044118X13475827

Cicchetti, D. (1984). The emergence of developmental psychopathology. Child Dev, 55:1-7.

Cicchetti, D. (2006). Development and Psychopatology. In D. Cicchetti \& D. Cohen (Eds.), Developmental psychopathology: theory and method (2nd ed., vol. 1, pp. 1-23). New York: Wiley.

Cicchetti, D. (2016). Developmental Psychopathology, 2nd Edition (Vol 1-4). New York, NY: Wiley.

Cicchetti, D., \& Cohen, D, J. (1995). Developmental Psychopathology, 2nd Edition (Vol. 12). Hoboken, NJ: Wiley.

Cicchetti, D., \& Cohen, D, J. (2006). Developmental Psychopathology, 2nd Edition (Vol 1-3). New York, NY: Wiley.

Cicchetti, D., \& Curtis, W. J. (2006). The Developing Brain and Neural Plasticity: Implications for Normality, Psychopathology, and Resilience. In D. Cicchetti \& D. Cohen (Eds.), Developmental psychopathology: theory and method (2nd ed., vol. 2, pp. 1-51). New York: Wiley.

Cicchetti, D., \& Rogosch, F. A. (1996). Equifinality and multifinality in developmental psychopathology. Development and Psychopathology, 8(4), 597-600. doi:10.1017/S0954579400007318

Cicchetti, D., \& Sroufe, L. A. (2000). Reflecting on the past and planning for the future of developmental psychopathology. Development and Psychopathology, 12(3), 255-550.

Clarivate Analytics. (2019). Web of Science platform: Web of Science: Summary of Coverage. Disponível em: https://clarivate.libguides.com/webofscienceplatform

Cohen, L., \& Felson, M. (1979). Social Change and Crime Rate Trends: A Routine Activity Approach. American Sociological Review, 44(4), 588-608. doi:10.2307/2094589

Comissão Pastoral da Terra. (2018). Conflitos no campo: Brasil 2017. Goiânia, GO: Centro de Documentação Dom Tomás Balduino - CPT. 
Confederação Nacional da Indústria. CNI. (2017). Retratos da Sociedade Brasileira: segurança pública. Ano 6, Número 38.

Costa, R. C. S., Komatsu, A. V., \& Bazon, M. R. (2017). Psychological Assessment of Adolescent Offenders: Validity of the Brazilian Jesness Inventory - Revised. International Annals of Criminology, 55, 60-77. doi:10.1017/cri.2017.2

Costa, R. C. S., Komatsu, A. V., \& Bazon, M. R. (2019). Avaliação Psicológica em Delinquência Juvenil: Precisão e Validade do Inventário de Jesness - revisado brasileiro. (Artigo em avaliação pelo periódico: Psico PUC RS)

Cullen, F. T., \& Kulig, T. C. (2018). Evaluating Theories of Environmental Criminology. Oxford Handbooks Online. doi:10.1093/oxfordhb/9780190279707.013.7

Curry, G. D. \& Spergel, I. (1988). Gang homicide, delinquency, and community. Criminology, 26, 381- 405 .

Dam, V., Hjordt, L., Cunha-Bang, S. D., Sestoft, D., Knudsen, G., \& Stenbæk, D. (2018). Five-factor personality is associated with aggression and mental distress in violent offenders. $\quad$ European $\quad$ Neuropsychopharmacology, 28. doi:10.1016/j.euroneuro.2017.12.061

Davies, H. J., \& Davidson, H. A. (2001). Parental Involvement Practices of Juvenile Courts. Report to the Office of Juvenile Justice and Delinquency Prevention, U.S. Department of Justice. Washington, DC: American Bar Association.

Day, D. M., Wanklyn, S.G., \& Yessine, A.K. (2014). A Review of Terminological, Conceptual, and Methodological Issues in the Developmental Risk Factor Literature for Antisocial and Delinquent Behavior. Child Youth Care Forum (2014) 43:97-112.

de Vries Robbé, M., Geers, M.C.K., Stapel, M., Hilterman, E.L.B., \& de Vogel, V. (2015). SAPROF - Youth Version English. Guidelines for the assessment of protective factors for violence risk in juveniles. English version. Utrecht: De Forensische Zorgspecialisten. 
de Vries Robbé, M., Mann, R. E., Maruna, S., \& Thornton, D. (2014). An Exploration of Protective Factors Supporting Desistance From Sexual Offending. Sexual Abuse: A Journal of Research and Treatment, 27(1), 16-33. doi:10.1177/1079063214547582

de Vries Robbé, M., \& de Vogel, V. (2013). Protective factors for violence risk: Bringing balance to risk assessment. In C. Logan, \& L. Johnstone (Eds.), Managing Clinical Risk: A guide to effective practice (pp. 293-310). London: Routledge.

Delisi, M. (2014). Low Self-Control Is a Brain-Based Disorder. In: BEAVER, Kevin; BARNES, JC; BOUTWELL, Brian. The nurture versus biosocial debate in criminology: on the origins of criminal behavior and criminality. Thousand Oaks: Sage Publication Inc. DeMatteo, D., Heilbrun, K., \& Marczyk, G. (2005). Psychopathy, risk of violence, and protective factors in a noninstitutionalized and noncriminal sample. The International Journal of Forensic Mental Health, 4(2), 147-157. doi:10.1080/14999013.2005.10471220

Desmarais, S. L., \& Singh, J. P. (2013). Risk Assessment Instruments Validated and Implemented in Correctional Settings in the United States. CSG Justice Center.

Desmarais, S. L., Johnson, K. L., \& Singh, J. P. (2017). Performance of Recidivism Risk Assessment Instruments in U.S. Correctional Settings. Handbook of Recidivism Risk/Needs Assessment Tools, 1-29. doi:10.1002/9781119184256.ch1

Diamond, A. (2013). Executive functions. Annual Review of Psychology, 64:135-168.

Dias, N. M., \& Seabra, A. G. (2012). Executive demands of the Tower of London task in Brazilian teenagers. Psychol. Neurosci. vol.5 no.1. doi:10.3922/j.psns.2012.1.09

Dib, M. A., Komatsu, A. V., \& Bazon, M. R. (2019). Regulação do comportamento delituoso na e pela família: um estudo comparativo. (Artigo em avaliação pelo periódico: Gerais: Revista Interinstitucional de Psicologia). 
Doran, B. J., \& Burgess, M. B. (2011). Why Is Fear of Crime a Serious Social Problem?. In Putting Fear of Crime on the Map. Springer Series on Evidence-Based Crime Policy. Springer, New York, NY. doi:10.1007/978-1-4419-5647-7_2

Douglas, K. S., Hart, S. D., Webster, C. D., Belfrage, H., Guy, L. S., \& Wilson, C. M. (2014). Historical-Clinical-Risk Management-20, Version 3 (HCR-20V3): Development and Overview. International Journal of Forensic Mental Health, 13(2), 93-108. doi:10.1080/14999013.2014.906519

Duggan E.C., Garcia-Barrera M.A. (2015) Executive Functioning and Intelligence. In: Goldstein S., Princiotta D., Naglieri J. (eds) Handbook of Intelligence. Springer, New York, NY. doi:10.1007/978-1-4939-1562-0_27

Duntley, J. D., \& Buss, D. M. (2011). Homicide adaptations. Aggression and Violent Behavior, 16:399-410. doi:10.1016/j.avb.2011.04.016

Elliott, D. S., Ageton, S. S., Huizinga, D., Knowles, B. A. \& Canter, R. J. (1983). Prevalence and Incidence of Delinquent Behavior: 1976-1980-National Estimates of Delinquent Behavior by Sex, Race, Social Class and Other Selected Variables. Washington, D. C.: U. S. Departament of Justice.

Engelhardt, C. R., \& Bartholow, B. D. (2013). Effects of Situational Cues on Aggressive Behavior. Social and Personality Psychology Compass, 7, 762-774. doi:10.1111/spc3.12067

Ennis, B. J., \& Litwack, T. R. (1974). Psychiatry and the Presumption of Expertise: Flipping Coins in the Courtroom. California Law Review, 62(3), 693. doi:10.2307/3479746

Enns, P. K. (2016). Incarceration Nation: How the United States Became the Most Punitive Democracy in the World. Cambridge University Press.

Eysenck, H. J. (1967). The biological basis of personality. Transaction Publishers. 
Farrington, D. P. (1977). The effects of public labelling. British Journal of Criminology, 17, 112-125. doi:10.1093/oxfordjournals.bjc.a046802

Farrington, D. (1995). Key issues in the integration of motivational and opportunity-reducing crime prevention strategies. In P. Wikstrom, R. Clarke, \& J. McCord (Eds.), Integrating crime prevention strategies: Propensity and opportunity (pp. 333-357). Stockholm, Sweden: National Council for Crime Prevention.

Farrington, D. P. (1977). The effects of public labelling. British Journal of Criminology, 17, 112-125. doi:10.1093/oxfordjournals.bjc.a046802

Farrington, D.P. (2000). Explaining and Preventing Crime: The Globalization of Knowledge. Criminology, 38(1):1-24. doi:10.1111/j.1745-9125.2000.tb00881.x

Farrington, D.P. (2003). Key Results from the First Forty Years of the Cambridge Study in Delinquent Development. In: T.P. Thornberry \& M.D. Krohn (Eds.). Taking Stock of Delinquency: An Overview of Findings from Contemporary Longitudinal Studies. New York: Kluwer Academic Publishers.

Farrington, D. P. (2005a). Integrated developmental and life-course theories of offending. New Brunswick: Transaction.

Farrington, D. P. (2005b). The integrated cognitive antisocial potential (ICAP) theory. In: D. P. Farrington (ed.), Integrated developmental and life-course theories of offending. New Brunswick: Transaction.

Farrington, D. (2014). Integrated Cognitive Antisocial Potential Theory. In G. Bruinsma \& D. Weisburd (eds.), Encyclopedia of Criminology and Criminal Justice. New York, NY: Springer. doi:10.1007/978-1-4614-5690-2

Farrington, D. P., Coid, J. W., Harnett, L., Jolliffe, D., Soteriou, N., Turner, R. \& West, D. J. (2006). Criminal careers up to age 50 and life success up to age 48: new findings from the 
Cambridge Study in Delinquent Development, 299 Gr. Brit. Home Off. Res. Dev. \& Stat. Dictorate 1, 4-5.

Farrington, D. P., \& Murray, J. (Eds.). (2014). Labeling theory: empirical tests. New Brunswick: Transaction Publishers.

Farrington, D. P., Piquero, A. R., \& Jennings, W. G. (2013). Offending from Childhood to Late Middle Age. Recent Results from the Cambridge Study in Delinquent Development. New York, NY: Springer. doi:10.1007/978-1-4614-6105-0

Farrington, D. P., \& Ttofi, M. M. (2015). Developmental and Life-Course Theories of Offending. In: J. Morizoti \& L. Kazemian (eds.), The Development of Criminal and Antisocial Behavior: Theory, Research and Practical Applications. Cham: Springer. doi:10.1007/978-3-319-08720-7

Farrington, D. P., Ttofi, M. M., \& Piquero, A. R. (2016). Risk, promotive and protective factors in youth offending: Results from the Cambridge Study in Delinquent Development. Journal of Criminal Justice, 45, 63-70. doi:10.1016/j.jcrimjus.2016.02.014

Fazel, S., \& Wolf, A. (2018). Selecting a risk assessment tool to use in practice: a 10-point guide. Evidence-Based Mental Health, 21:41-43.

FBSP. Fórum Brasileiro de Segurança Pública. (2017). Anuário Brasileiro de Segurança Pública 2017. 11 a edição. São Paulo, SP: Fórum Brasileiro de Segurança Pública.

FBSP. Fórum Brasileiro de Segurança Pública. (2018). Anuário Brasileiro de Segurança Pública 2018. São Paulo, SP: Fórum Brasileiro de Segurança Pública.

Fonseca, A. C. (2000). Comportamentos anti-sociais: Uma introdução. Revista Portuguesa de Pedagogia, Ano XXXIV, no 1, 2 e 3, 9-36.

Franke, T. M. (2000). The role of attachment as a protective factor in adolescent violent behavior. Adolescent \& Family Health, 1(1), 40-51. 
Frankenhuis, W. E., \& Del Giudice, M. (2012). When do adaptive developmental mechanisms yield maladaptive outcomes? Dev Psychol, 48(3):628-42. doi:10.1037/a0025629

Frost, E., \& Nowak, M. (2014). Inclusive Security, Inclusive Cities. Geneva Declaration. Policy Paper 1.

Gavrilova, E. , Kamada, T. and Zoutman, F. (2017). Is Legal Pot Crippling Mexican Drug Trafficking Organisations? The Effect of Medical Marijuana Laws on US Crime. Econ J. doi:10.1111/ecoj.12521

Garofalo, J. (1981). The fear of crime: causes and consequences. Journal of Criminal Law and Criminology, 72(2): 839.

Gibson, C. L., Zhao, J., Lovrich, N. P., \& Gaffney, M. J. (2002). Social Integration, Individual Perceptions of Collective Efficacy, and Fear of Crime in Three Cities. Justice Quarterly, 19: 537-564. doi:10.1080/07418820200095341

Glowacz F., Born M. (2015). Away from Delinquency and Crime: Resilience and Protective Factors. In: Morizot J., Kazemian L. (eds) The Development of Criminal and Antisocial Behavior. Springer: Cham.

Goodnight, J. A., Bates, J. E., Holtzworth-Munroe, A., Pettit, G. S., Ballard, R. H., Iskander, J. M., ... Lansford, J. E. (2017). Dispositional, demographic, and social predictors of trajectories of intimate partner aggression in early adulthood. Journal of Consulting and Clinical Psychology, 85(10), 950-965. doi:10.1037/ccp0000226

Gottfredson, M. (2018). Self-Control Theory and Criminal Violence. In A. Vazsonyi, D. Flannery, \& M. DeLisi (Eds.), The Cambridge Handbook of Violent Behavior and Aggression (Cambridge Handbooks in Psychology, pp. 301-323). Cambridge: Cambridge University Press. doi:10.1017/9781316847992.018 
Gottfredson, M. R., \& Hirschi, T. (1990). A general theory of crime. Stanford: Stanford University Press.

Gottfredson D.M., \& Tonry M. (1987). Prediction and classification: criminal justice decision making. Chicago, IL: University of Chicago Press; 1987.

Guedes, I., Moreira, S., Teixeira, N., \& Cardoso, C. (2018). Podemos reduzir a insegurança? Um enfoque no ambiente físico. In C. Agra \& M. A. Gomes (orgs.), Criminologia Integrativa: contributos para uma comunidade criminológica de Língua Portuguesa. Belo Horizonte, MG: D’Plácido.

Hawkins, J. D., Herrenkohl, T. I., Farrington, D. P., Brewer, D., Catalano, R. F., Harachi, T. W., \& Cothern, L. (2000). Predictors of Youth Violence. Washington, DC: Office of Juvenile Justice and Delinquency Prevention - Juvenile Justice Bulletin. doi:10.1037/e524202006-001

Hawkins, J. D, Jenson, J. M., Catalano, R. F., \& Lishner, D. M. (1988). Delinquency and Drug Abuse: Implications for Social Services. Social Service Review, 62(2):258-284.

Hilton, N. Z., \& Simmons, J. L. (2001). The influence of actuarial risk assessment in clinical judgments and tribunal decision about mentally disordered offenders in maximum security. Law and Human Behavior, 25, 393-408. doi:10.1023/A:1010607719239

Hirschi, T. (1969). Causes of delinquency. Berkeley, CA: University of California Press.

Hoeve, M., Dublas, J. S., Eichelsheim, V. I., Van der Laan, P. H., Smeenk, W., \& Gerris, J. R. M. (2009). The Relationship Between Parenting and Delinquency: A Meta-analysis. J Abnorm Child Psychol, 37(6):749-775. doi:10.1007/s10802-009-9310-8

Hong, J. S., Huang, H., Golden, M., Patton, D. U., \& Washington, T. (2014) Are Community Violence-Exposed Youth at Risk of Engaging in Delinquent Behavior? A Review and Implications for Residential Treatment Research and Practice. Residential Treatment for Children \& Youth, 31(4):266-283. doi:10.1080/0886571X.2014.958343 
Hughes, C., \& Ensor, R. (2010). Do Early Social Cognition and Executive Function Predict Individual Differences in Preschoolers' Prosocial and Antisocial Behavior? In B. Sokol, U. Muller, J. Carpendale, A. Young \& F. Iarocci (org.), Self and social regulation: social interaction and the development of social understanding and executive functions. New York, NY: Oxford University Press.

IBGE. Instituto Brasileiro de Geografia e Estatística. (2016). Pesquisa nacional de saúde escolar. Rio de Janeiro: Instituto Brasileiro de Geografia e Estatística.

Ipea \& FBSP. (2018). Atlas da Violência 2018. Rio de Janeiro: Ipea e Fórum Brasileiro de Segurança Pública.

Jackson, J., Gray, E. (2010). Functional fear and public insecurities about crime. Br J Criminol, 50(1):1-22. doi:10.1093/bjc/azp059

Janssen, H.J., Eichelsheim, V.I., Deković, M., \& Bruinsma, G. J. N. (2017). Sex differences in longitudinal pathways from parenting to delinquency. Eur J Crim Policy Res, 23(4):503-521. https://doi.org/10.1007/s10610-017-9350-5

Jesness, C. F. (2003). Jesness Inventory-Revised. Technical Manual. North Tonawanda, USA: MHS.

Jolliffe, D., \& Farrington, D. P. (2009). Effectiveness if interventions with adult male violent offenders. Swedish National Concil for Crime and Prevention (Brottsförebyggande rådet). Stockholm: Edita Norstedts Vasteras.

Jolliffe, D., Farrington, D. P., Loeber, R., \& Pardini, D. (2016). Protective factors for violence: Results from the Pittsburgh Youth Study. Journal of Criminal Justice, 45, 32-40. doi:10.1016/j.jcrimjus.2016.02.007

Justice Policy Institute. (2009). The costs of confinement: Why good juvenile justice policies make good fiscal sense. Washington, DC: Justice Policy Institute. 
Kandel, E. R. (1998). A new intellectual framework for psychiatry. American Journal of Psychiatry, 155, 475-469.

Kandel, E. R. (1999). Biology and the future of psychoanalysis: A new intellectual framework for psychiatry revisited. American Journal of Psychiatry, 156, 505-524. doi:10.1176/ajp.156.4.505

Kandel, E. R. (2013). From Nerve Cells to Cognition: The Internal Representations of Space and Action. In E. R. Kandell, J. H. Schwartz, T. M. Jessell, S. A. Siegelbaum \& A. J. Hudspeth (org.) Principles of Neural Science, 5th edition. New York, NY: McGraw-Hill, Health Professions Division.

Klein, M., Adda, C. C., Miotto, E. C., Lucia, M. C. S., \& Scaff, M. (2010). O paradigma stroop em uma amostra de idosos brasileiros. Psicologia Hospitalar, 8(1), 93-112.

Knutsson, J. (1977). Labeling theory: a critical examination. Scientific Reference Group, National Swedish Council for Crime Prevention. Stockholm: Brottsförebyggande rådet.

Komatsu, A. V. (2014). Comportamentos antissociais em adolescentes do sexo masculino: estudo exploratório na cidade de Ribeirão Preto - SP. Dissertação de Mestrado, Faculdade de Filosofia, Ciências e Letras de Ribeirão Preto, Universidade de São Paulo, Ribeirão Preto.

Komatsu, A.V. \& Bazon, M.R. (2015). Caracterização de adolescentes do sexo masculino em relação a comportamentos antissociais. Revista Latinoamericana de Ciencias Sociales, Niñez y Juventud, 13(2): 725-735. doi:10.11600/1692715x.13212210814.

Komatsu, A. V., \& Bazon, M. R. (2016). Adolescentes em conflito com a lei: justiça juvenil pela perspectiva da criminologia desenvolvimental. In S. Nojiri (Org) Direito, Psicologia e Neurociência. 1a ed. Ribeirão Preto, SP: IELD. 186p.

Komatsu, A. V., \& Bazon, M. R. (2017a). Crime and Antisocial Behaviors in Male Adolescents: An Exploratory Study in the City of Ribeirão Preto, São Paulo Brazil. In E. 
Viano (ed.), Cybercrime, Organized Crime, and Societal Responses: international approaches. Washington, DC: Springer. 380p.

Komatsu, A. V., \& Bazon, M. R. (2017b). Personal differences among Brazilian adolescents with different levels of criminal engagement. International Journal of Criminology \& Sociology, 6: 65-74. doi:10.6000/1929-4409.2017.06.07

Komatsu, A. V., \& Bazon, M. R. (2018). Fatores de risco e de proteção para emitir delitos violentos: revisão sistemática da literatura. Perspectivas em Psicologia, 22(1): 180-206.

Komatsu, A. V., Costa, R. C. S., Bazon, M. R. (2018). Delinquência juvenil: relações entre desenvolvimento, funções executivas e comportamento social na adolescência. Rev. Bras. Polít. Públicas, Brasília, v. 8, nº 2, p.979-999. doi:10.5102/rbpp.v8i2.5289

Komatsu, A. V., Costa, R. C. S., Salgado, F. S., \& Bazon, M. R. (2019). Evidências de precisão e de validade do Questionário sobre Comportamentos Juvenis (QCJ). (Artigo em avaliação pelo periódico: Perspectivas em Psicologia)

Komatsu, A. V., Santos, A. L. M., \& Bazon, M. R. (2019). Evaluación de las funciones ejecutivas en jóvenes infractores violentos, no violentos y no infractores. (Livro em processo de editoração da Red Española de Jóvenes Investigadores en Criminología).

Komatsu, A. V., Wenger, L., Costa, R. C. S., Bazon, M. R., \& Andres-Pueyo, A. (2019). Factores protectores en adolescentes infractores: un estudio tipológico. International EJournal of Criminal Sciences. (Artigo em processo de publicação)

Kraemer, H.C., Kazdin, A.E., Offord, D.R., Kessler, R.C., Jensen, P.S., \& Kupfer, D.J. (1997). Coming to terms with the terms of risk. Archives of General Psychiatry, 54, 337343. doi:10.1001/archpsyc.1997.01830160065009

Krahé, B. (2013). The social psychology of aggression (2nd ed.). New York, NY: Psychology Press. 
Lahey, B. B., \& Waldman, I. D. (2005). A developmental model of the propensity to offend during childhood and adolescence. In D. P. Farrington (Ed.), Integrated developmental and life-course theories of offending (pp. 15-50). New Brunswick, NJ: Transaction.

Lally, S. J. (2003). What tests are acceptable for use in forensic evaluations?: A survey of experts. Professional Psychology: Research and Practice, 34, 491-498.

Lanctôt, N., \& Le Blanc, M. (1996). La participation des garçons à une bande marginale: un phénomène de sélection et d'opportunités. Revue canadienne de criminologie, vol. 38, pp. $375-400$.

Large, M., \& Nielssen, O. (2017). The limitations and future of violence risk assessment. World psychiatry: official journal of the World Psychiatric Association, 16(1), 25-26. doi:10.1002/wps.20394

Larsen, R. J., \& Buss, D. M. (2014). Personality psychology: domains of knowledge about human nature. New York: McGraw-Hill Education.

Le Blanc, M. (1997). A generic control theory of the criminal phenomenon, the structural and the dynamical statements of an integrative multilayered control theory. In T.P. Thomberry (ed.), Developmental theories of crime and delinquency. Advances in theoretical criminology, 7:215-286. New Brunswick, Transaction Publishers.t

Le Blanc, M. (2002). The Offending Cycle, Escalation and De-escalation in Delinquent Behavior: A Challenge for Criminology. International Journal of Comparative and Applied Criminal Justice. Spring 2002, Vol. 26, No 1.

Le Blanc, M. (2003). Trajetórias de delinquência comum, transitória e persistente: uma estratégia de prevenção diferencial. In: I. Alberto (org.) Comportamento Antissocial: Escola e Família (pp. 31-80). Coimbra: Centro de Psicopedagogia da Universidade de Coimbra. 
Le Blanc, M. (2005). An integrated personal control theory of deviant behavior: Answers to contemporary empirical and theoretical developmental criminology issues. In D. P. Farrington (Ed.), Integrated developmental and life-course theories of offending (pp.125163). New Brunswick, NJ: Transaction.

Le Blanc, M. (2009). The development of deviant behavior, its self-regulation. Monatsschrift fur Kriminologie und Strafrechtsreform (Journal of Criminology and Penal Reform), 92, $117-136$.

Lewis, M. (2014). Toward the Development of the Science of Developmental Psychopathology. In: M. Lewis \& K. Rudolphi (eds.), Handbook of Developmental Psychopathology, 3ed. New York, NY: Springer. doi:10.1007/978-1-4614-9608-3

Lindberg, N., Miettunen, J., Heiskala, A., \& Kaltiala-Heino, R. (2017). Mortality of young offenders: A national register-based follow-up study of 15- to 19-year-old Finnish delinquents referred for forensic psychiatric examination between 1980 and 2010. Child and Adolescent Psychiatry and Mental Health, 11(1). doi:10.1186/s13034-017-0174-3

Lipsey, M. W., \& Derzon, J. H. (1998). Predictors of serious delinquency in adolescence and early adulthood: A synthesis of longitudinal research. In Serious and Violent Juvenile Offenders: Risk Factors and Successful Interventions, edited by R. Loeber and D.P. Farrington. Thousand Oaks, CA: Sage Publications, Inc., 86-105.

Lipsey, M. W., Howell, J. C., Kelly, M. R., Chapman, G., \& Carver, D. (2010). Improving the effectiveness of juvenile justice programs: A new perspective on evidence-based practice. Washington, DC: Center for Juvenile Justice Reform.

Loeber, R., \& Farrington, D. (1998). Serious and Violent Offenders: Risk Factors and Sucessful Interventions. Thousand Oaks, CA: Sage. 
Loeber, R., Farrington, D.P., \& Petechuk, D. (2013). Bulletin 1: From Juvenile Delinquency to Young Adult Offending (Study Group on the Transitions between Juvenile Delinquency and Adult Crime). Report of U.S. Department of Justice.

Loinaz, I., Andrés-Pueyo, A., \& Pereira, R. (2017). Factores de riesgo de violencia filioparental: Una aproximación con juicio de expertos. Acción Psicológica, 14(2), 17-32.

Lorenc, T., Petticrew, M., Whitehead, M., Neary, D., Clayton, S., Wright, K., Thomson, H., Cummins, S., Sowden, A., \& Renton, A. (2013). Fear of crime and the environment: a systematic review of UK qualitative evidence. BMC Public Health, 13(496), 1-8. doi:10.1186/1471-2458-13-496

Luciana, M., Collins, P. F., Olson, E. A., \& Schissel, A. M. (2009). Tower of London performance in healthy adolescents: The development of planning skills and associations with self-reported inattention and impulsivity. Developmental Neuropsychology, 34(4), 461-475. doi:10.1080/87565640902964540

Luthar, S. S. (2006). Resilience in Development: A Synthesis of Research across Five Decades. In D. Cicchetti \& D. Cohen (Eds.), Developmental psychopathology: theory and method (2nd ed., vol. 3, pp. 740-783). New York: Wiley.

Luthar, S. S., Cicchetti, D., \& Becker, B. (2000). The construct of resilience: A critical evaluation and guidelines for future work. Child Development, 71, 543-562.

Luthar, S. S., \& Zelazo, L. B. (2003). Research on resilience: An integrative review. In S. S. Luthar (Ed.), Resilience and vulnerability: Adaptation in the context of childhood adversities (pp. 510-549). New York: Cambridge University Press.

MacLeod, C. M. (1991). Half a century of research on the Stroop effect: An integrative review. Psychological Bulletin, 109, 163-203. doi:10.1037/0033-2909.109.2.163

Manzi-Oliveira, A. B. (2012). Avaliação de adolescentes em conflito com a lei: adaptação transcultural do Inventário de Personalidade de Jesness (Dissertação de Mestrado). 
Faculdade de Filosofia, Ciências e Letras de Ribeirão Preto, Universidade de São Paulo, Ribeirão Preto.

Maruschi, M. C., \& Bazon, M. R. (2014). Justiça Juvenil: a aplicação e a execução das medidas socioeducativas pelos parâmetros do modelo "risco-necessidaderesponsividade". Prêmio INNOVARE: 10 anos - A justiça do século XXI. 1ed.Rio de Janeiro: Andrea Jakobsson: Instituto INNOVARE, v. 01, p. 42-72.

Masten, A. (2001). Ordinary magic: Resilience processes in development. American Psychologist, 56(3), 227-238. doi:10.1037/0003-066X.56.3.227

Masten, A. S., Best, K., \& Garmezy, N. (1990). Resilience and development: Contributions from the study of children who overcome adversity. Development and Psychopathology, 2, 425-444. doi:10.1017/S0954579400005812

Mears, D. P., Stewart, E. A., Warren, P. Y., \& Simons, R. L. (2016). Culture and Formal Social Control: The Effect of the Code of the Street on Police and Court Decisionmaking. Justice Quarterly, 34(2), 217-247. doi:10.1080/07418825.2016.1149599

Miller, P. A., \& Eisenberg, N. (1988). The relation of empathy to aggressive and externalizing/antisocial behavior. Psychological Bulletin, 103(3), 324-344. doi:10.1037//0033-2909.103.3.324

Mills, J. F., Kroner, D. G., \& Morgan, R. D. (2011). Clinician's guide to violence risk assessment. New York, NY: The Guilford Press.

Minayo, M. C. S. (2005). Violência: um problema para a saúde dos brasileiros. In BRASIL, Impacto da violência na saúde dos brasileiros. Brasília, DF: Ministério da Saúde.

Moffitt, T. E. (1993). Adolescence-limited and life-course-persistent antisocial behavior: a developmental taxonomy. Psychol Rev, 100(4):674-701.

Moffitt, T. E. (2018). Male antisocial behaviour in adolescence and beyond. Nature Human Behaviour, v. 2, n. 3, p. 177-186. 
Moffitt, T. E., Arseneault, L., Belsky, D., Dickson, N., Hancox, R. J., Harrington, H., ... Caspi, A. (2011). A gradient of childhood self-control predicts health, wealth, and public safety. Proceedings of the National Academy of Sciences, 108(7), 2693-2698. doi:10.1073/pnas.1010076108

Moffitt, T. E., Caspi, A., Rutter, M., \& Silva, P. A. (2001). Sex differences in antisocial behaviour: Conduct Disorde, delinquency, and violence in the Dunedin longitudinal study. Cambridge: Cambridge University Press.

Moffitt, T. E., Krueger, R. F., Caspi, A., \& Fagan, J. (2000). Partner abuse and general crime: how are they the same? How are they different? Criminology, 38: 199-232.

Monahan, J., \& Skeem, J. L. (2016). Risk Assessment in Criminal Sentencing. Annu. Rev. Clin. Psychol, 12:489-513. doi:10.1146/annurev-clinpsy-021815-092945

Monahan, K. C., Steinberg, L., Cauffman, E., \& Mulvey, E. P. (2013). Psychosocial (im)maturity from adolescence to early adulthood: Distinguishing between adolescencelimited and persisting antisocial behavior. Development and Psychopathology, 25(4pt1), 1093-1105. doi:10.1017/s0954579413000394

Mora, V., \& Decker, S. H. (2018). Youth gang and violent behavior. In A. Vazsonyi, D. Flannery, \& M. DeLisi (Eds.), The Cambridge Handbook of Violent Behavior and Aggression (Cambridge Handbooks in Psychology, pp. 491-512). Cambridge: Cambridge University Press. doi:10.1017/9781316847992.028

Morgan, R. D., Flora, D. B., Kroner, D. G., Mills, J. F., Varghese, F., \& Steffan, J. S. (2012). Treating offenders with mental illness: a research synthesis. Law and human behavior, 36(1), 37-50. doi:10.1037/h0093964

Mrug, S., Madan, A., \& Windle, M. (2016). Emotional Desensitization to Violence Contributes to Adolescents' Violent Behavior. Journal of abnormal child psychology, 44(1), 75-86. doi:10.1007/s10802-015-9986-х 
Nagin, D. S. (2005). Group-Based Modeling of Development Over the Life Course. Cambridge, MA: Harvard University Press.

Nagin, D. S., \& Odgers, C. L. (2010). Group-Based Trajectory Modeling (Nearly) Two Decades Later. J Quant Criminol. 2010 Dec; 26(4): 445-453. doi:10.1007/s10940-0109113-7

Newsome, J., Vaske, J. C., Gehring, K. S., \& Boisvert, D. L. (2016). Sex Differences in Sources of Resilience and Vulnerability to Risk for Delinquency. J Youth Adolesc, 45(4):730-45. doi:10.1007/s10964-015-0381-2

NGIC. National Gang Intelligence Center. (2016). 2015 National Gang Report. National Gang Intelligence Center.

Nicholson, R. A., \& Norwood, S. (2000). The quality of forensic psychological assessments, reports, and testimony: Acknowledging the gap between promise and practice. Law and Human Behavior, 24, 9-44. doi:10.1023/A:1005422702678

Olofsson, N., Lindqvist, K., Shaw, B. A., \& Danielsson, I. (2012). Long-term health consequences of violence exposure in adolescence: a 26-year prospective study. BMC public health, 12, 411. doi:10.1186/1471-2458-12-411

OMS. Organização Mundial da Saúde. (2009). Preventing violence by developing life skills in children and adolescents. Series of briefings on violence prevention. Malta: WHO press.

OMS. Organização Mundial da Saúde. (2016). Homicide WHO Global Health Estimates (2015 update). Retrieved December 25, 2018 from: http://apps.who.int/violenceinfo/homicide/

Papageorgiou, K. A., \& Ronald, A. (2017). The Genetic Basis of Psychological Traits in Infancy: Implications for Understanding the Causes of Developmental Psychopathology. In L. C. Centifanti \& D. M. Williams (eds.), The Wiley Handbook of Developmental Psychopathology. Hoboken, NJ: Willey.

Patchin, J. W., Huebner, B. M., McCluskey, J. D., Varano, S. P., \& Bynum, T. S. (2006). Exposure to community violence and childhood delinquency. Crime \& Delinquency, 52, 307-332. doi:10.1177/0011128704267476 
Paul, N., \& Piquero, A. R. (2008). Mortality Rates and Causes of Death of Convicted Dutch Criminals 25 Years Later. Journal of Research in Crime and Delinquency, 45(3), 256. doi:10.1177/0022427808317573

Pfohl, S., \& Monahan, J. (1983). Predicting Violent Behavior: An Assessment of Clinical Techniques. Contemporary Sociology, 12(2):174. doi:10.2307/2066734

Pham, T., Vanderstukken, O., Philippot, P., \& Vanderlinden, M. (2003). Selective attention and executive functions deficits among criminal psychopaths. Aggressive Behavior, 29(5), 393-405. doi:10.1002/ab.10051

Phillips, L. H. (1999). The Role of Memory in the Tower of London Task. Memory, 7:2, 209231. doi:10.1080/741944066

Piquero, A. R. (2000). Assessing the relationships between gender, chronicity, seriousness, and off ense skewness in criminal off ending. Journal of Criminal Justice, 28, 103-115.

Pizzaro, J. M. \& McGloin, J. M. (2004). Explaining gang homicides in Newark: Collective behavior or social disorganization? Paper presented at the 2004 Meeting of the American Society of Criminology, Nashville, TN.

Polanczyk, G. V. (2009). Em busca das origens desenvolvimentais dos transtornos mentais. Rev Psiquiatr RS., 31(1):6-12

Pollak, S. D. (2015). Developmental psychopathology: recent advances and future challenges. World Psychiatry, 14(3), 262-269. doi:10.1002/wps.20237

Pollard, J.A., Hawkins, J.D., \& Arthur, M.W. (1999). Risk and protection: Are both necesssary to understand diverse behavioral outcomes in adolescence? Social Work Research, 23, 145-158. doi:10.1093/swr/23.3.145

Ribeiro, E., \& Cano, E. (2016). Vitimização letal e desigualdade no Brasil: evidências em nível municipal. Civitas, 16(2), 285-305. doi:10.15448/1984-7289.2016.2.23066

Ross, C. E., \& J. Mirowsky. (2000). Disorder and decay: the concept and measurement of perceived neighborhood disorder. Urban Affairs Review 34(3): 412-433. 
Rueve, M. E., \& Welton, R. S. (2008). Violence and mental illness. Psychiatry (Edgmont), 5(5):34-48.

Rutter, M. (1979). Protective factors in children's responses to stress and disadvantage. Annals of the Academy of Medicine, 8(3):324-338.

Rutter, M. (1985). Resilience in the face of adversity: Protective factors and resistance to psychiatric disorder. British Journal of Psychiatry, 147, 598-611.

Rutter, M. (2008). Developing concepts in developmental psychopathology. In J. J. Hudziak (ed.), Developmental Psychopathology and Wellness: genetic and environmental influences, 1ed. Washington, DC: American Psychiatry Publishing.

Rutter, M., \& Garmezy, N. (1983). Developmental psychopathology. In E. M. Hetherington (Ed.), Handbook of child psychology (4th ed., Vol. 4, pp. 774-911). New York, NY: Wiley.

Rutter, M., \& Giller, H. (1983). Protective factors. In Juvenile Delinquency: Trends and Perspectives. New York: Guilford.

Salgado, F. (2017). Comportamentos divergentes e delituosos em adolescents do sexo feminino e variáveis psicológicas e sociais associadas. Tese de Doutorado, Faculdade de Filosofia, Ciências e Letras de Ribeirão Preto, Universidade de São Paulo, Ribeirão Preto.

Salzinger, S., Ng-Mak, D. S., Feldman, R. S., Kam, C.-M., \& Rosario, M. (2006). Exposure to Community Violence: Processes That Increase the Risk for Inner-City Middle School Children. The Journal of Early Adolescence, 26(2), 232-266. doi: $10.1177 / 0272431605285712$

Sampson, R. J., \& Laub, J. H. (2005). A general agegraded theory of crime: Lessons learned and the future of life-course criminology. In D. P. Farrington (Ed.), Integrated developmental and life-course theories of offending (pp. 165-181). New Brunswick, NJ: Transaction.

Santos, A. L. M., Komatsu, A. V., \& Bazon, M. R. (2019). Aspectos de personalidade em adolescentes infratores violentos e não violentos segundo Inventário de Jesness: um estudo comparativo. Gerais: Revista Interinstitucional de Psicologia, 12(2).

Sapori, L. F., Caetano, A. J., \& Santos, R. F. (2018). A reincidência juvenil no estado de Minas Gerais. Belo Horizonte, MG: Tribunal de Justiça do Estado de Minas Gerais. 
Sapori, L. F., Santos, R. F., Wan der Maas, L. (2017). Fatores sociais determinantes da reincidência criminal no brasil: o caso de Minas Gerais. RBCS, v. 32, n. 94, p. 1-18.

Samuels, R., \& B. Judd (2002). Public housing estate renewal: Interventions and the epidemiology of victimisation. Housing, Crime and Stronger Communities Conference, Melbourne, Australian Institute of Criminology \& Australian Housing and Urban Research Institute.

Sartin, R. M., Hansen, D. J., \& Huss, M. T. (2006). Domestic violence treatment response and recidivism: A review and implications for the study of family violence. Aggression and Violent Behavior, 11(5), 425-440. doi:10.1016/j.avb.2005.12.002

Séguin, J. R., Booij, L., Lilienfeld, S. O. (2018). The neuropsychology of violence. In A. Vazsonyi, D. Flannery, \& M. DeLisi (eds.), The Cambridge Handbook of Violent Behavior and Aggression (Cambridge Handbooks in Psychology, pp. 136-158). Cambridge: Cambridge University Press. doi:10.1017/9781316847992.009

Seifert, K. (2012). Youth violence: theory, prevention and intervention. New York, NY: Springer Publishing Company.

Semel, R. A. (2016). Incorporating the Jesness Inventory-Revised (JI-R) in a Best-Practice Model of Juvenile Delinquency Assessments. Journal of Forensic Psychology Practice, vol 16. doi:10.1080/15228932.2016.1119516

Shallice, T. (1982). Specific impairments of planning. Philosophical Transactions of the Royal Society B: Biological Sciences, 298, 199-209.

Silva, J. L, Cianflone, A. R. L., \& Bazon, M. R. (2016). School Bonding of Adolescent Offenders. Paidéia (Ribeirão Preto), 26(63), 91-100. doi:10.1590/1982-43272663201611

Simon, J. (2007). Governing Through Crime: How the War on Crime Transformed American Democracy and Created a Culture of Fear. Oxford University Press. 
Simunovic, D., Mifune, N., \& Yamagishi, T. (2013). Preemptive strike: An experimental study of fear-based aggression. Journal of Experimental Social Psychology, 49(6), 11201123. doi:10.1016/j.jesp.2013.08.003

Singh, J.P., Grann, M., \& Fazel, S. (2011). A comparative study of risk assessment tools: A systematic review and metaregression analysis of 68 studies involving 25,980 participants, Clinical Psychology Review. doi:10.1016/j.cpr.2010.11.00

Smith, C, Lizotte, A. J., Thornberry, T. P., \& Krohn, M. D. (1995). Resilient youth: Identifying factors that prevent high-risk youth from engaging in delinquency and drug use. In Z. S. Blau \& J. Hagan (Eds.), Current perspectives on aging and the life cycle. Greenwich, CT: Jai Press.

Soares, R. (2005). Mortality Reductions, Educational Attainment, and Fertility Choice. American Economic Review, 95(3), 580-601.

Sommerfeldt, E. (2013). The civility of social capital: public relations in the public sphere, civil society, and democracy. Public Relations Review, 39(3), 280-289. Doi:10.1016/j.pubrev.2012.12.004

Spelman, W. (2004). Optimal targeting of incivility-reduction strategies. Journal of Quantitative Criminology 20(1): 63-88.

Sroufe, L. A., \& Rutter, M. (1984). The domain of developmental psychopathology. Child Development, 55, 17-29.

Stoddard, S. A., Zimmerman, M. A., \& Bauermeister, J. A. (2012). A Longitudinal Analysis of Cumulative Risks, Cumulative Promotive Factors, and Adolescent Violent Behavior. Journal of research on adolescence: the official journal of the Society for Research on Adolescence, 22(3), 542-555. doi:10.1111/j.1532-7795.2012.00786.x 
Strauss, E., Sherman, E. M. S., \& Spreen, O. (2006). A compendium of neuropsychological tests: administration, norms, and commentary. $3^{\circ}$ Ed. Oxford University Press: New York, 2006.

Stroebe, W., Leander, N. P., \& Kruglanski, A. W. (2017). Is It a Dangerous World Out There? The Motivational Bases of American Gun Ownership. Personality and Social Psychology Bulletin, 43(8), 1071-1085. doi:10.1177/0146167217703952

Sutherland, E. H. (1947). Criminology (4th ed). Chicago, J.B. Lippincott.

Swartz, M. S., Bhattacharya, S., Robertson, A. G., \& Swanson, J. W. (2016). Involuntary Outpatient Commitment and the Elusive Pursuit of Violence Prevention. Canadian journal of psychiatry. Revue canadienne de psychiatrie, 62(2), 102-108. doi:10.1177/0706743716675857

Sylvers, P., Ryan, S.R., Alden, S.A., \& Brennan, P.A. (2009). Biological Factors and the Development of Persistent Criminality. In Joane Savage (ed.) Development of Persistent Criminality, New York: Oxford University Press.

Tella, R. D., Freira, L., Gálvez, R., Schargrodsky, E., Shalom, D., \& Sigman, M. (2017). Crime and Violence: Desensitization in Victims to Watching Criminal Events. doi: $10.3386 / \mathrm{w} 23697$

Telles, L. E. B., Day, V. P., Folino, J. O., \& Taborda, J. G. (2009). Reliability of the Brazilian version of HCR-20 Assessing Risk for Violence. Revista Brasileira de Psiquiatria, $31,253-256$.

Telles, L. E. B., Folino, J. O., \& Taborda, J. G. (2012). Accuracy of the Historical, Clinical and Risk Management Scales (HCR-20) in predicting violence and other offenses in forensic psychiatric patients in Brazil. International Journal of Law and Psychiatry, 35(56), 427-431. doi:10.1016/j.ijlp.2012.09.001 
Thornberry TP (1987) Toward an interactional theory of delinquency. Criminology 25:863891

Thornberry, T.P., \& Krohn, M. D. (2001). The development of delinquency: an interactional perspective. In: S. O. White (ed.), Handbook of youth and justice. Plenum, New York, pp 289-305

Thornberry, T. P., \& Krohn, M. D. (2005). Applying interactional theory to the explanation of continuity and change in antisocial behavior. In: D. P. Farrington (ed.), Integrated developmental and life course theories of offending, vol 14, Advances in Criminological Theory. Transaction, Piscataway, pp 183-210.

Tobar, F. S. (2015). Tendências criminais sul-americanas em perspectiva comparada. Rev. bras. segur. pública, 9(2), 88-109.

Tolman, A. O., \& Mullendore, K. B. (2003). Risk evaluations for the courts: Is service quality a function of specialization? Professional Psychology, Research and Practice, 34, 225232. doi:10.1037/0735-7028.34.3.225

Ttofi, M. M., Farrington, D. P., Piquero, A. R., Lösel, F., DeLisi, M., \& Murray, J. (2016). Intelligence as a protective factor against offending: A meta-analytic review of prospective longitudinal studies. Journal of Criminal Justice, 45, 4-18. doi:10.1016/j.jcrimjus.2016.02.003

Unterrainer, J. M., Rahm, B., Kaller, C. P., Leonhart, R., Quiske, K., Hoppe-Seyler, K...Halsband, U. (2004). Planning abilities and the Tower of London: Is this task measuring a discrete cognitive function? Journal of Clinical and Experimental Neuropsychology, 26(6), 846-856. doi:10.1080/13803390490509574

Van de Weijer, S., Augustyn, M. B., \& Besemer, S. (2017). Intergenerational transmission of crime. The Routledge International Handbook of Life-Course Criminology, 279-297. doi:10.4324/9781315747996-16 
Vassallo, S., Edwards, B., \& Forrest, W. (2016). Childhood behavior problems and fighting in early adulthood: What factors are protective? Journal of Criminal Justice, 45, 85-93. doi:10.1016/j.jcrimjus.2016.02.010

Veneziano, C., Veneziano, L., LeGrand, S., \& Richards, L. (2004). Neuropsychological executive functions of adolescent sex offenders and nonsex offenders. Percept Mot Skills, 98(2):661-74. doi:10.2466/pms.98.2.661-674

Vigil, J. D. (2004). The gang subculture and locura: Variations in acts and actors. In R. Martinez Jr. (Ed.) Beyond racial dichotomies of violence: Immigrants, ethnicity, and race. New York: Routledge.

Visioli, M. M. M. R. (2017). Comportamentos divergentes e delituosos autorrevelados em adolescentes do sexo masculino estudantes de escolas particulares. Dissertação de Mestrado, Faculdade de Filosofia, Ciências e Letras de Ribeirão Preto, Universidade de São Paulo, Ribeirão Preto.

Vogel, V. D., de Vries Robbé, M. D., Ruiter, C. D., \& Bouman, Y. H. (2011). Assessing Protective Factors in Forensic Psychiatric Practice: Introducing the SAPROF. International Journal of Forensic Mental Health, 10(3), 171-177. doi:10.1080/14999013.2011.600230

Wadsworth, M. E. (2015). Development of Maladaptive Coping: A Functional Adaptation to Chronic, Uncontrollable Stress. Child development perspectives, 9(2), 96-100. doi:10.1111/cdep.12112ç

Webster, C., Douglas, K., Eaves, D., \& Hart, S. (1997). HCR-20: Assessing risk for violence. Version 2. Burnaby, British Columbia: Simon Fraser University and Forensic Psychiatric Services Commission of British Columbia.

Webster, C. D., Hucker, S. J., \& Bloom, H. (2002). Transcending the actuarial versus clinical polemic in assessing risk for violence. Criminal Justice and Behavior, 29(5), 659-665. doi:10.1177/009385402236736 
Welsh, E., Bader, S., \& Evans, S. E. (2013). Situational variables related to aggression in institutional settings. Aggression and Violent Behavior, 18(6), 792-796. doi:10.1016/j.avb.2013.10.003

Wendland-Carro, J., Piccinini, C. A., \& Millar, W. S. (1999). The Role of an Early Intervention on Enhancing the Quality of Mother-Infant Interaction. Child Development, 70(3), 713-721. doi:10.1111/1467-8624.00051

White, J., Moffitt, T., Earls, R., Robins, L., \& Silva, P. (1990). How early can we tell? Predictors of childhood conduct disorder and adolescent delinquency. Criminology, 28:507-533. doi:10.1111/j.1745-9125.1990.tb01337.x

Wikström, P-O H., 2005. The social origins of pathways in crime. Towards a developmental ecological action theory of crime involvement and its changes. In: D. P. Farrington (ed.), Integrated developmental and life-course theories of offending. Advances in Criminological Theory, Volume 14. New Brunswick: Transaction, pp.211-246. 